
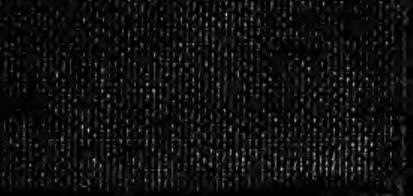

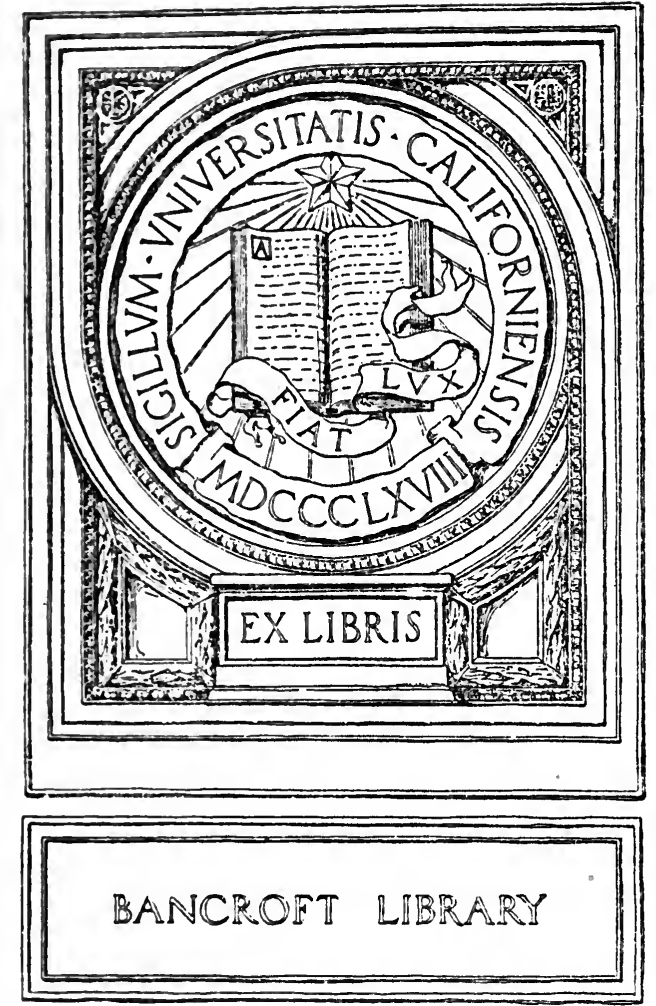

Digitized by the Internet Archive in 2007 with funding from Microsoft Corporation 


\section{MEXICO AND ITS RECONSTRUCTION}






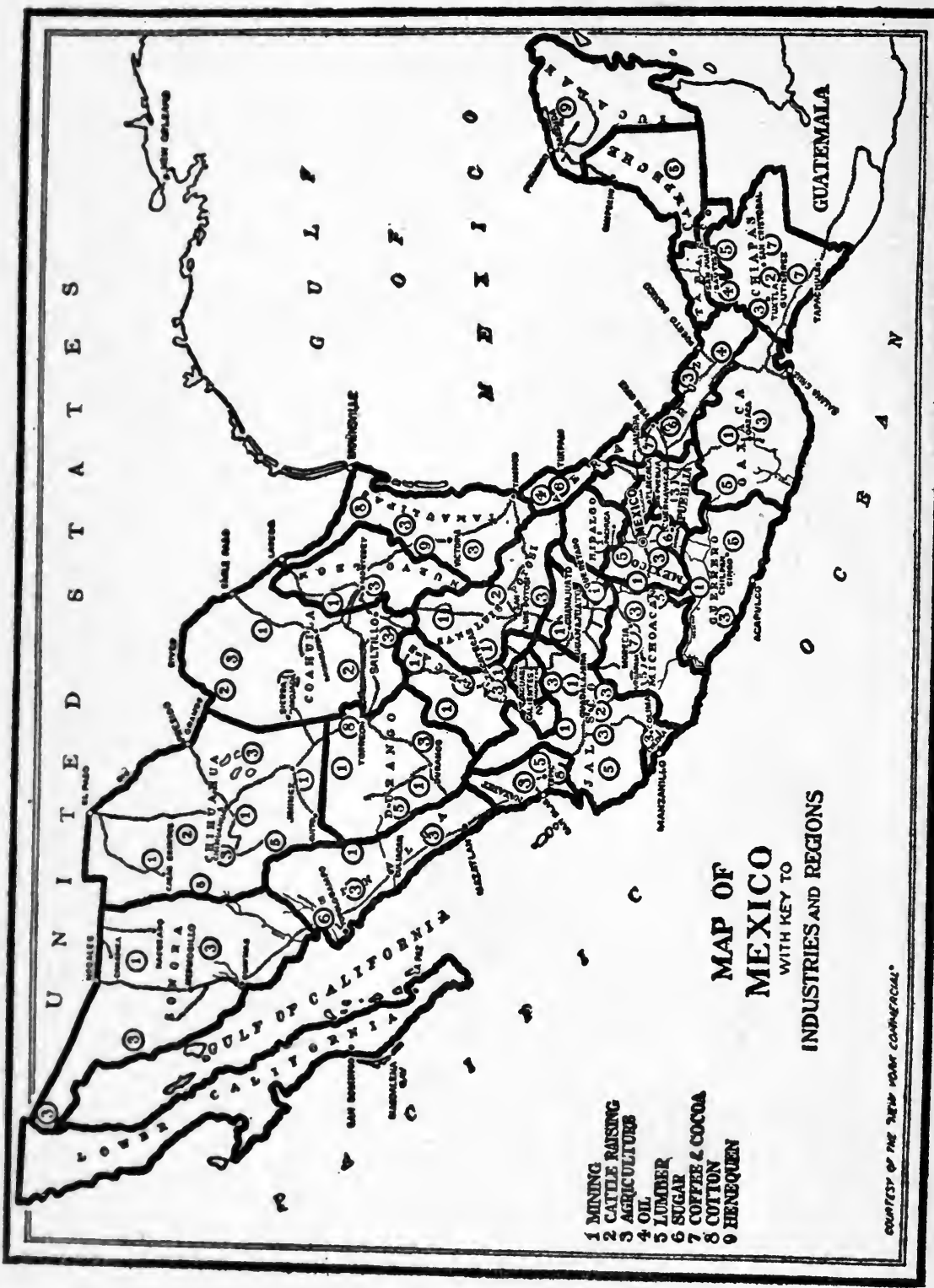




\section{MEXICO AND ITS RECONSTRUCTION}

BY

\section{CHESTER LLOYD JONES}

SOMETIME PROTESSOR OF POLITICAL SCIENCE IN THE UNIVERSITY OF WISCONSIN, COMMERCIAL ATTACH TO SPAIN, ETC.; AUTHOR OF "THM CONSULAR SERVICE OF THE UNITED states," "STATUTh LAW MakiNg iN THE UNITED statRs," "CARIBAEAN INTERESTS OF THE ONITED STATES," FTC. 


\section{COPYRIGHT, I92I, BY \\ D. APPLETON AND COMPANY}


MY WIFE

CAROLINE S. LLOYD JONES 



\section{PREFACE}

The developments in Mexico during the period that has come to be known as "the old régime" were of peculiar interest to the more advanced nations of Europe and America. It seemed as if here was a republic that was proving that self-government and the guarantee of public order were not incompatible with a geographical position in the sub-tropics and a population predominantly of Indian blood.

What has happened since the fall of Diaz would have been more closely followed by the western world had not the World War absorbed its energy and attention. Mexico became for the moment a factor that was considered less for itself and more in its possible relation to the general conflict. With the end of the war events in Mexico assume greater importance. The revolution has proved that the government was not yet on a foundation so firm as was supposed. The task of the reformers is to find means to make it firm. The brilliant economic show of the Diaz régime must be supplemented by a transformation in social and political conditions. Efforts to bring the new day will be closely watched by those who have capital invested in Mexico itself, by those with economic interests in other undeveloped regions, by students of international affairs, especially in Europe and America, and by students of government the world around.

At the beginning of the century the less informed had come to look upon the problems that might arise in Mexico as similar to those which might arise in the United States, in Great Britain, or in France. Many of those who knew Mexico best held the same belief-the economic foundation of the country was secure, only time was needed for the elimination of the back- 
ward conditions still characteristic of the national life. Such a judgment was mistaken and unfair to Mexico. The republic was not yet to be measured by the standards of Western Europe.

Nor is it fair to expect that the internal problems that confront the governments that follow the revolution can be solved in a period of a few years no matter how favorable the auspices under which the reforms are undertaken. It is too easy to be encouraged by a temporary or local improvement in con'ditions. There will be many surprising advances' and disappointing backslidings before Mexico is surely on the road to becoming a modern state.

It is because he overlooks these facts that the judgment of the average man in Europe and the United States upon conditions in Mexico and the policy that should be adopted toward the republic is of such little weight. He measures Mexico by the standards to which he himself is accustomed, and what information he possesses is usually derived from the accounts of current events in periodical publications. As a matter of fact, what happens to-day or to-morrow in Mexico, whether this leader or that is in control, defeated, exiled, or killed, is probably of little importance. Such items are worthy of study only as they indicate a general tendency of development in domestic affairs or possible complications with foreign powers. Unfortunately it must be admitted that current events for the past decade in Mexico have too often been so confused that no constructive development could be discerned.

To understand Mexico and the Mexican problem it is necessary to study more than current political happenings and trade exchange. It is necessary to know, among other elements, the racial endowment of the people, the character of the governments under which they have lived, the obligations the government has assumed toward other nations and their citizens, the social and economic organization of Mexican society, the character of internal and foreign commerce, the development of transportation facilities, the position of those of other than Mexican nationality who have made the republic their home, 


\section{PREFACE}

and the relations of Mexico with other states, particularly its neighbors.

No state in our day lives unto itself alone. It must be in touch with the outside world and especially with the nations upon which it borders. It is for this reason that the relations of the United States to Mexico have become so important and are sure in the future to be of even greater moment. What affects one cannot fail to affect the other. Already the more obvious of international relationships between the two are emphasized in an unusual degree. American investments in Mexico far exceed those of any other foreign country. The foreign trade of Mexico with the United States is more important for Mexico than that with all the rest of the world combined, a condition which the developments during the World War have accentuated. The foreign relations of the two countries have an intimate connection-neither can feel itself safe without the friendship of the other. Failure to realize their political unity of interest might endanger the foreign policy which the United States has for a century defended, to assure the free development of all the American republics.

No single volume can give a detailed picture of such complex elements as those cited in the preceding paragraphs. It may, however, help to indicate the various factors that must be taken into consideration by the individual and by the state of which he forms a part in arriving at a judgment of what may fairly be expected of a government working under such conditions as will confront Mexico during its trying period of reconstruction. It is hoped that this book may assist its readers in forming such a judgment and may stimulate them to further study of the problems which it outlines. How important an intelligent understanding of these problems is for both Mexico and the United States is realized by only a small portion of the peoples of the two republics.

The materials used in the preparation of this book have been largely the official publications of Mexico and of the United States. These have been supplemented by the studies made by 
students of the repablic both Mexican and foreign. From neither of these sources alone nor by both together is a satisfactory picture of Mexican conditions derivable, and at many points the testimony of periodicals and of residents of the republic must be accepted as the best information available. This is true especially for recent years, but in a measure also in discussing the earlier periods, for the formal history of Mexico, economic, political and social, is to an unusual degree unwritten.

My thanks are due to the authorities of the University of California and to those of the Library of Congress at Washington for facilities placed at my disposal. I am indebted also to friends too numerous to mention for suggestions and criticism, to Dr. Norman Bridge, who has read the manuscript, and to Mr. Edward L. Doheny, whose establishment of the Doheny Foundation made available valuable source materials relating to Mexican-American relations.

Chester Lloyd Jones 


\section{CONTENTS}

PAGE

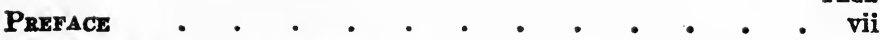

I. Why Mexico Is a Problem . • • • • • • • 1

II. The Population of Mexico . • • • • • • • 10

III. The Government of Mexico: Executife Government - 28

IV. The Government of Mexico: Elections . . . . . . 42

V. The Government of Mexico: The Sitate and Local GovERMMENTS • • • • • • • • • • • 58

Vi. Mexican finance: Foreign loans and Foreign Clamms . 66

VII. Mexican Finance: Currency and the Banks • • • 83

VIII. Mexican Finance: Pubuc Incomb and Expenditure • • 94

IX. The Mexican Laborer - • • • • • • • . 104

X. The Mexican Laborer: His Contract . . . . . 114

XI. The Mexican Laborer: His Wages and Demands . - . 135

XII. The Mexican Laborer: His Opportunities . . . . 148

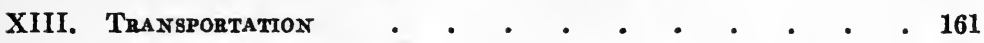

XIV: Industry and Internal Commerce • • • • • • 175

XV. 'The Foreigr Commerce of Mexico: Before Diaz . . . 187

XVI. The Foreign Commerce of Mexico: The Diaz Régime and

AfTER . . . . . . . . . . . . 199

XVII. Colonization • • • • • • • • • • • 220

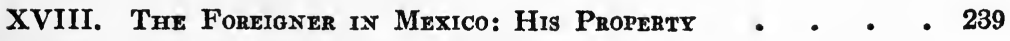

XiX. The Foreigner in Mexico: His Legal Position • • . 253

XX. The Troublesome Border . • • • • • • . 271

XXI. Mexican-American Relations • • $\bullet \quad \bullet \quad \ddots \quad: \quad$ • 297

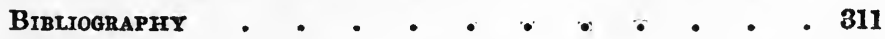

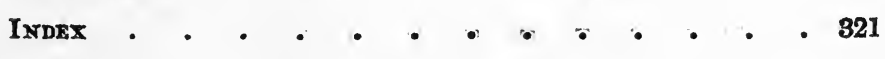




\title{
MEXICO AND ITS RECONSTRUCTION
}

\author{
CHAPTER I \\ WHY MEXICO IS A PROBLEM
}

A generation ago few Americans recognized that Mexico was a problem and still fewer that it was one that deeply concerned the United States. For more than a half century it had been a country in which civil dissension was seldom absent. It was a land almost unknown, one in which the stagnation of the Spanish colonial system of government had been succeeded by the stagnation which comes from lack of enterprise, lack of education, and lack of intelligent and efficient government. The dictatorship which had been set up recently had shown signs of strength, it is true, greater than its short-lived predecessors, and railway building had made a promising beginning but the outside world still looked upon Mexico as a problem to itself and a matter of comparative indifference to others.

But the past generation has seen an internationalizing of the affairs of the world that has made it impossible for any state to remain isolated from the affairs of its neighbors. Strictly speaking, of course, national interests are not bounded by national frontiers and they. 
never have been. They are less so now than ever before. As communication and commercial interchanges develop international contacts become more important. As emigration from one country to another increases the obligations of countries to protect the rights of resident foreigners increase. Independence is replaced by an interlocking of interests that demands a recognition of the fact that no state can longer be independent as it was in times past.

The emphasis of duties of this sort does not greatly. increase the burdens of the stronger powers nor those of the lesser states that have created orderly governments capable of protecting life and property. Weaker nations are able to give a less effective guarantee to foreigners and to their own citizens. As a result, in spite of the theory of equality of states, in practice the more advanced states exercise a constant pressure upon the weaker to assure that they exert themselves to guarantee safety for life and property. The pressure may be veiled but it is none the less real. If the responsibility. is not assumed, there is always the possibility of recourse to force. Many examples could be cited. The demands made upon Venezuela in the opening years of the century and the claims for indemnities arising from the Boxer rebellion in China are illustrations of the ways in which reparations may be sought. That there is possibility of abuse in such circumstances is beyond dispute, but the alternative-to allow the weaker state a free hand in the persecution of foreigners-would be a policy even less endurable. Such a policy is intolerable under modern conditions when both population and capital 


\section{WHY MEXICO IS A PROBLEM}

pass frontiers in normal times with insignificant difficulties and do so in response to invitation and even solicitation by foreign countries and their citizens.

All around the world the problems of the weak states promise to hold the front of international attention during the coming decade. In fact the elimination of "unredeemed lands" and the efforts to exploit resources now undeveloped will emphasize the international importance of unprotected interests in disordered states. Though it does not greatly increase their domestic problems the passing of the day when each state was a law unto itself creates new international responsibilities for the stronger nations toward the weaker.

The regions of the world in which the problem of the protection of foreign interests promises to be most important are three. In eastern Europe and the Near East it is evident that the settlements following the World War cannot set up states that will at once be able to discharge easily all the responsibilities toward their neighbors and toward resident foreigners that the great powers will wish to have assumed. The Far East will have important problems of adjustment.

Finally there is the unstable area in America-extending from the Rio Grande to northern South America. Africa will probably be less important in matters of this sort because, but for Abyssinia and Liberia, it has ceased to be a region in which there are so-called sovereign states and its other native peoples under European influence, except in Egypt and Morocco, have shown no nationalistic aspirations or aptitudes.

In the American area control by the most powerful 
American state over its weaker neighbors has been growing steadily for two decades. The responsibilities assumed in Cuba and Panama have been followed by others, which now include practical protectorates over all of the West Indian republics and a complex of responsibilities in Central America.

Although this extension of influence has been steady it has not been the result of any well thought out plan, indeed, to a very large degree, it has been a product of circumstances rather than of policy. It is not an increase of control which the government or people of the United States has actively desired and it is not one which either wishes to see further extended. Nevertheless it can but be evident that the circumstances that are developing in the world will make the policy to be followed toward the countries encircling the Caribbean one of the leading factors in American foreign policy in the immediate future.

One of the most important problems that American statesmen will have to face and one of the most difficult of the adjustments that must be made during the period of reconstruction following the World War involves the relations of the United States and Mexico. The foreign policy adopted toward this, the most important of the Latin republics of North America, may be the outstanding factor in American international policy in the next decade. The solution arrived at will be important for the world at large, and especially for the United States, for a large number of reasons.

1. From the broadest international viewpoint it will be significant because it will show what standard is 


\section{WHY MEXICO IS A PROBLEM}

found practical by a power that has prominently declared its altruistic motives in its actions toward weaker nations. Though the United States has a better perspective in such matters now than at the beginning of the century, it is still less experienced in dealing with weaker peoples than Great Britain and France, the chief European powers that in the near future will be called upon to deal with similar situations. As a consequence the United States approaches the Mexican problem with perhaps greater possibility of error but less bound by precedent.

2. Contrasts in civilization are present in high degree in the Mexican problem. Anglo-Saxon and Latin customs and languages meet. Within Mexico itself there are many contrasts and conflicts arising out of the native elements of the population and the lack of communication between the various districts of the country. From a cultural standpoint these have kept the republic, to a great degree, a collection of units rather than a single state and will make a satisfactory solution of Mexican relations difficult.

3. The great natural wéalth of Mexico makes it a region in which the adjustment of its political and economic relations with the rest of the world is of great importance.

4. What may be called the resident international interests within Mexico emphasize the fact that arrangements concerning its government are not merely of local concern. During the Diaz period of orderly government an inflow of foreign capital occurred that makes what happens to the investments in the country a mat- 
 \\ MEXICO AND ITS RECONSTRUCTION}

ter of unusual international interest. Of the investments made those representing American capital are by far the most important.

5. Its international trade exchange makes a country of importance in international affairs. The economic development of Mexico since the '80s of the past century has made it one of the most important of the American republics in foreign commerce. In both the imports and exports of Mexico the United States plays a part far more important than any other power.

6. Mexican affairs are of special interest to the United States, furthermore, because Mexico is the nearest of foreign countries. The two republics are neighbors with adjoining properties and what affects one must have an effect upon the other.

7. The developments that occur in Mexico will have a wider influence on American foreign policy than appears at first sight, for Mexican relations are in a peculiar way a thermometer for Pan-American relations. Whether the assumption is justified or not, any measure adopted toward Mexico is apt to be taken by other Latin American states as a measure of what may be expected for themselves, however different the conditions to be met in the two cases may be. This is unfortunate but true. Obviously that which may be demanded from Haiti for the protection of the rights of the United States would be unnecessary in a country of the orderly character of Argentina or Chile. Nevertheless the Latin American countries consider themselves a group with common interests and a step that affects one is looked upon as indicating a policy toward the rest. There can 
be no doubt that whatever is done by the United States in Mexico will have a very clear repercussion on the Pan-Americanism of which the United States has been an exponent and defender. What the policy has meant has never been definitely stated. The idea greatly needs clarifying. Pan-Americanism of the sort that has been popular in some quarters in the past will become more and more difficult to maintain. The actual developments in world affairs promise little for any policy that can be interpreted as inconsistent with a recognition that "independence" carries great and increasing responsibilities toward foreign states and individuals.

8. The relations of the United States and Mexico have an interest not limited to America. In dealing with Mexico the northern republic will have a complex problem involving contrasting civilizations and the meeting of a people with wide experience in democratic institutions with one almost unexperienced in popular government, though nominally devoted to its ideals. Its policy will be influenced by the measures taken to develop the latent natural resources and the already important foreign trade and investments. Mexico is the greatest and wealthiest of the weak states of predominantly aboriginal population that lie near to a great Western power. Obviously the political and economic adjustments that are found possible under such circumstances cannot fail to be of interest to all the world and especially to those powers which have close contact with the less developed independent nations.

9. Finally, the Mexican problem is one that has unusual interest for the world and especially for the 


\section{MEXICO AND ITS RECONSTRUCTION}

United States because it seems sure to have a rapid development. Had not the World War absorbed the attention of the world, the conditions that have developed south of the Rio Grande would almost surely have been followed before now by international action. The interests of the United States would have prompted it but, even if the desire not to offend the susceptibilities of the other Latin American states had delayed action, and even if those who believe that the government owes no responsibility to its citizens who invest their lives and property in foreign lands had been able to hold back the hand of the administration, some forward step would almost certainly have been found necessary.

Even if the United States had been willing to suffer and wait, it seems little likely that other powers would have been content to do so. That they would not have. been willing is indicated by the action taken by European powers toward Haiti in the days immediately preceding the World War. The larger interests held by the citizens of European governments in Mexico would have prompted them to take measures to protect their interests there if the United States would not. A threat to do so is the easiest way to force the American hand.

As in civil society, so in international affairs, the shortcomings of the weak are the problems of the strong. As the period of reconstruction progresses, Mexican affairs will again assume importance not only in American international policy but in that of all the great powers. There must be created within the republic a government that can establish order, that will respect individual rights, put the great resources of the nation again at the 
service of those living within its borders, and enable it to contribute its due share to the maintenance of the family of nations. To make that possible all true friends of Mexico and all true friends of the United States must strive. 


\section{CHAPTER II}

\section{THE POPULATION OF MEXICO}

ONE of the most easily understood errors into which we fall is to suppose that political boundaries coincide with those of race and culture. Before the World War how many could have named the lesser peoples who, in the course of the conflict, raised their claims to the right of self-determination and political independence? Few. indeed.

When we think of Mexico, we fall into the same error. There have been no important population movements within the territory of the greatest of the Latin republics in North America since the region has been known to Western civilization. There has been no immigration from abroad that has brought in an element that puts forth a claim for a government independent of the rest of the republic. There have been no racial or social barriers which had to be broken down to allow Mexico to become a unit in fact as well as in name. Nevertheless there is to-day no Mexican people, though we speak of one. There never has been one. The feeling of nationality is here one of those artificially created phenomena, the strength of which so often proves out of all proportion to that of the base upon which they rest.

The description of the ideal state conceived by some theorists, "an ethnic unity living within a geographic unity" is fully applicable to but few, if any, nations. It is far from describing the population of Mexico. The 
Mayas, the Zapotecs, the Yaquis, these are all Mexican citizens but the political bond is almost the only one that unites them. Historically, culturally, economically they have little in common that indicates that they should owe a common allegiance.

Above the native stocks are the mixed bloods who have at least the common bond of their racial connection and above these are those of European lineage, descendants of the immigrants of colonial times or of later arrivals. These two latter classes, by their adaptability and by their more intimate contact with the civilization of the outside world, are the cement of the Mexican peoples.

It is hard to secure information that will give a satisfactory picture of Mexican life because neither the government nor any private agency has ever attempted a thoroughgoing survey of economic and social conditions. ${ }^{1}$ 'There has never been an accurate census of the peoples of Mexico that established even their number much less one that gives a picture of their economic and social status and organization. For the earlier years only the roughest estimates are available and for the later ones enumerations by the government must be relied upon, which, while nominally complete, have not been based upon an actual count in many parts of the republic.

The records of colonial times are more complete, in fact, than those of the first fifty years of the republic because for the estimates referring to that time the par-

${ }^{2}$ An excellent recent study in this field is Wallace Thompson, The People of Mexico, New York, 1921. 


\section{MEXICO AND I'TS RECONSTRUCTION}

ish registers of all who were born or who died in the republic were available. The first general census was not taken until the close of the nineteenth century but even after that event an authoritative Mexican work declares that "nothing can be asserted honestly about the growth of population of Mexico considering the want of facts and the defectiveness of the few we possess." ${ }^{2}$ In spite of this stricture the various estimates that have been made from time to time are presented to indicate, if not the exact conditions, the opinion of those best informed concerning them.

A report to the king in $\mathbf{1 7 9 3}$ represented the population as totaling 4,483,529. Humboldt estimated it to be $5,783,750$ in 1803 . In 1823 it was thought to be about $6,998,337 .^{3}$ The census of 1855 put the population at $8,069,046.4$ In 1877-8 it was announced by the government as $10,577,279$, an average of 4.89 per square kilometer. The central states such as Aguascalientes and

${ }^{2}$ Justus Sierra, editor, Mexico, Its Social Evolution, vol. i, p. 19. The first general census was taken in October, 1895.

3 The estimates for 1793,1803 , and 1823 are quoted from Joel Roberts Poinsett, Notes on Mexico, accompanied by an historical sketch of the revolution, Philadelphia, 1824, p. 109.

4 Estadistica de la republica mexicana. Estado que guardan la agricultura, industria, mineria, y comercio; Anexo num. 3 a la memoria "de hacienda 'del año economico de 1877 a 1878, Mexico, 1880, p. 420. Carlos Butterfield, in United States and Mexico, p. 58, published in 1861, quoting the "latest and best authenticated returns," gave the population as $8,283,088$. Antonio Garcia Cubas and George F. Henderson in The Republic of Mexico, in 1876, estimated the population at $9,495,157$ souls.

- Estadistica de la republica mexicana. Estado que guardan la agricultura, ińdustria, mineria, y comercio; Anexo num. 3 a la 
Puebla had between twenty and thirty people to the square kilometer, the south was less populated. Chiapas averaged about nine and Yucatan three. The north was sparsely populated and large districts were practically unoccupied. Sonora had only about 1.5 to the square kilometer, Coahuila 1.4, Chihuahua 1.2, and the arid territory of Lower California one person to six square kilometers. In 1890 the total was estimated at 11,$632,924,{ }^{6}$ and the census of 1910 declared that there were $15,160,369$ souls in the republic. ${ }^{7}$

It appears that through all the history of the republic the population has had a slow but fairly steady increase. It has never been sufficient to develop the resources of the country, an inability accentuated by lack of capital and lack of technical education. The country may still be divided into three zones as to density of population as at the beginning of the Diaz régime. First there is the group of border states next to the United States, a

memoria de hacienda del año economico de 1877 a 1878, Mexico, 1880 , p. 420.

6 The following schedule of estimates for the first part of the Diaz régime is quoted in Luis Pombo, Mexico: 1876-1892, Mexico, 1893, p. 1 :

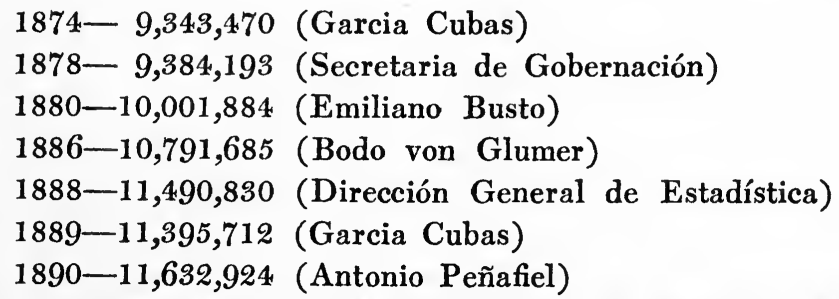

For further discussion of this subject see Wallace Thompson, op. cit., pp. 56-85.

'Boletin de la dirección general de estadística, 5, Mexico, 1914, p. 18. 


\section{MEXICO AND I'TS RECONSTRUCTION}

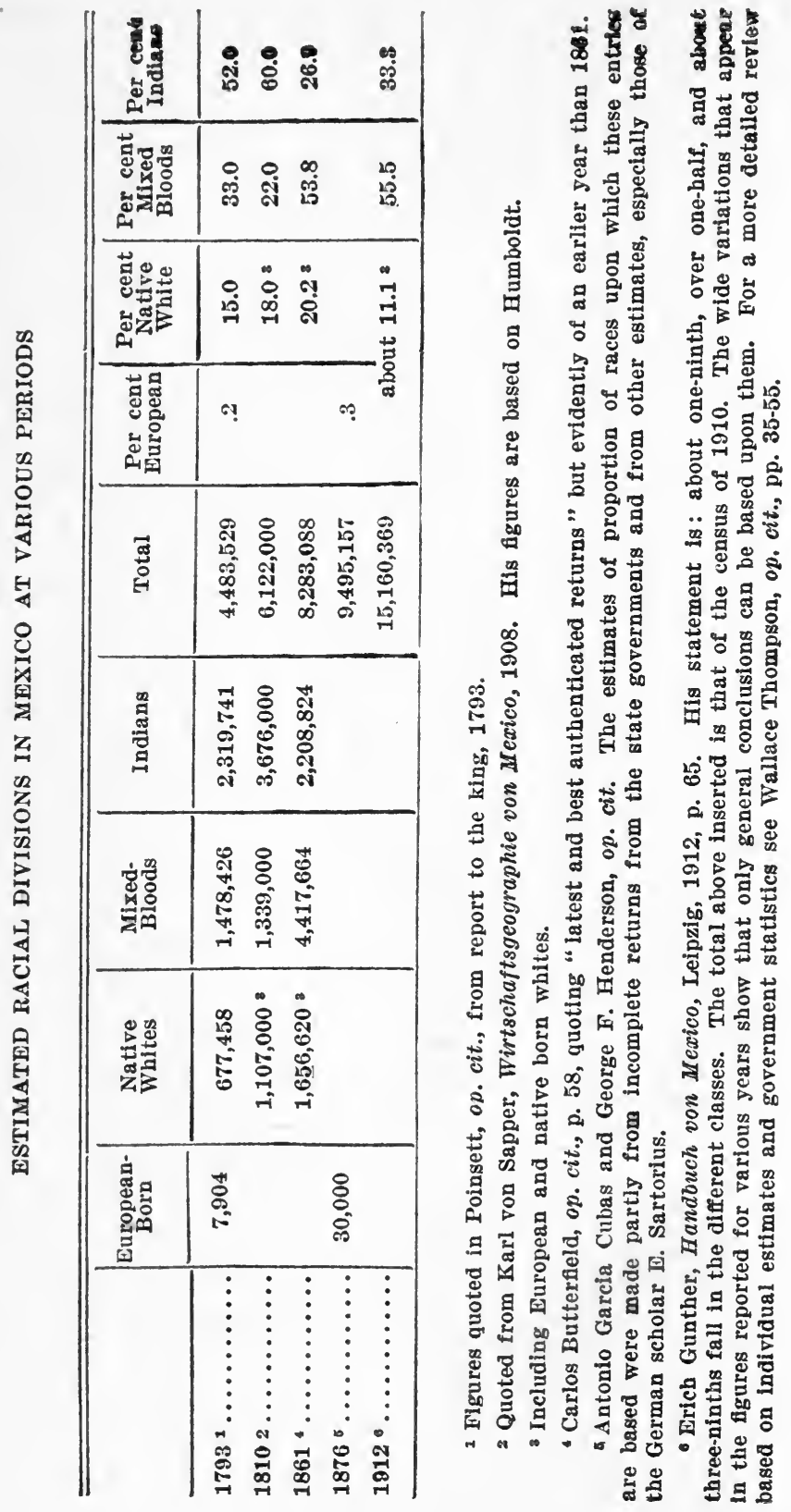


large portion of the area of which is taken up by mountains and by great plains of scant rainfall. This area has always been sparsely populated and, it seems, must continue to be so. The percentage of white blood among its people is higher than in other regions and they have contributed beyond what would be indicated by their numbers to the initiative for development that has been shown in Mexico.

The Gulf and Pacific coast states form another group. The former are on the average less thickly populated than the latter, though Lower California is an exception, great areas being still without population. Jalisco, Michoacan, and Oaxaca have been the most thickly populated and important states of the Pacific group.

Now as always, however, the greater part of the Mexican population is found in the states of the central plateau, where the civilization of the country also finds its best development.

If it is difficult to ascertain the population of Mexico, it is even more difficult to find out the proportion in which the various racial elements are represented. The report to the king in 1793, above referred to, gave the total number of Europeans as 7,904, white creoles 677,458, castes 1,478,426, and Indians 2,319,741. This would have made the percentages .2; 15.; 33.; and 52., respectively. ${ }^{8}$ An approximate picture of the racial developments since that time may be secured from the estimates, official and unofficial, made at various periods as shown in the table opposite,

${ }^{8}$ Compiled from the figures in Poinsett, op. cit. 
The proportions of these racial classes vary greatly in different parts of the country. In the north the Indian tribes as such have practically disappeared. The Tarahumaras and Tepehuanas and especially the Yaquis, living in regions until recently little valued by the whites, by their resistance to further encroachments on their rights have had more attention drawn to them than their number warrants. In the south the indigenes are in general a larger part of the population. Guerrero and Michoacan inhabited by the Tarascas; Oaxaca with its Miztecs in the west and Zapotecs in the east; and Yucatan, Campeche, and Chiapas, in which the population is very largely of the Maya group, are the most distinctively Indian areas.

The number of the pure Indians has decreased relatively with the gradual spread of intermarriage with whites and mixed bloods and doubtless will continue to do so. In a large part of the republic, however, they are the most important part of the population numerically and they are the chief source of the labor supply.

The descriptions of the Indians of Mexico at various periods in the history of the republic are almost interchangeable. In general they have kept, with but slight modification, the customs they had four centuries ago when America was discovered. In many parts of the country they continue to live in almost complete isolation, sufficient unto themselves. Even now they con-

${ }^{9}$ See a discussion of these points in Erich Gunther, Handbuch von Mexico, Leipzig, 1912, p. 65 et seq., and Wallace Thompson, op. cit., pp. 3-34 and 56-85. 
sume little from abroad and their demands are so few that they produce little that enters into general trade within the country itself. Nor do they contribute to export trade in proportion to their numbers. They are not now and they never have been important in the creation of public wealth. ${ }^{10}$

At the other end of the racial scale is the white population which, since the time of the Spanish dominion, has shown a preference for life in the cities, especially the capital. In Mexico, however, there does not exist any sharp social cleavage such as separates those of color from the Caucasian in the United States. This has always been the case. The Spanish colonist did not as a rule bring with him a wife or wife and children but took unto himself a native wife and from such unions have sprung the mixed bloods who form the increasing percentage of the population of Mexico. There are among the upper class Mexicans many who are proud of pure Castilian descent and who evidence a desire to pass it on to their children, but this feeling appears to be one resting on tradition and family pride rather than on racial feeling. There is little if any disadvantage under which a person of mixed blood works in business life or in the seeking of public office. ${ }^{11}$

The mestizo population, which has arisen between the

${ }^{10}$ Memoria de hacienda y credito publico . . . 1 de Julio de 1891 a 30 de Junio 1892, Mexico, 1892, p. 21 et seq. For a very similar description of the Indian population in 1824 see Poinsett, op cit., pp. 109-141.

${ }^{11}$ An interesting discussion of race mixtures at the beginning of the Diaz régime in Mexico is found in Antonio Garcia Cubas and George F. Henderson, op. cit., pp. 12-20. 
unleavened Indian peoples and those of white blood, constitutes at the present time over half of the total. It is the hope of some friends of Mexico and the desperation of others. In the opinion of most observers it is an improved stock as compared to the aborigines, quick to learn but inconstant in the application of the lessons taught. At present this population drifts as far as may be into the lighter occupations. Unfortunately it shows an unwillingness to undertake manual labor and a desire for an education of a literary or professional sort that will assure that physical labor will be unnecessary.

These are the people upon whom the future Mexico will depend, but from whom she has not yet received constructive leadership. Their ability to develop the qualities of constancy and responsibility, which they now lack, will determine whether Mexico assumes the independent position economically and politically that her physical endowment indicates is possible. Unless the trend of immigration changes, thus upsetting the racial developments now in progress, Mexico seems destined to become a mestizo republic. It is already far on the way to becoming one.

Perhaps no characteristic of Mexican life speaks more plainly of the diversity of the elements entering into its composition than the languages spoken by the peoples of the republic. To appreciate the degree to which the existence of the many tongues found in use indicates lack of unity one must bear in mind the immobile character of the population, the low state of education, and the lack of facilities for communication, all elements that work for particularism. 
The great majority of Mexicans, of course, speak Spanish. Of those included in the language enumeration in 1914, 88 per cent used Spanish as the usual means of communication. The rest were divided among 48 enumerated tongues. The Nahuatl or Mexicano was still used by over half a million, the Maya by 227,883 , the Zapoteco by 224,863, and the Otomi by 209,640 . None of the others were spoken by as many as one hundred thousand and some were evidently disappearing remnants. ${ }^{12}$ Nevertheless that the Spanish tongue has not been adopted by so large a proportion of Mexicans in the four hundred years since dominion was established is an indication that the church, the school, and the government have all failed to bring a large number of Mexicans into touch with European standards of civilization.

One of the least satisfactory of the schedules of any census is that dealing with religion, because the declaration of membership in a church made to the enumerator may mean merely an occasional attendance or an almost inherited membership. The religious census of Mexico is not an exception. The conversion of the country to Christianity after the conquest was accomplished under circumstances similar to all those of the time. It was a surface conversion and often hardly that. Even up to the present time though 99 per cent of the population are listed as Catholics, the depth of the belief of a large part of the ignorant lower classes is obviously not great.

${ }^{12}$ Boletin de la dirección general de estadística, 5, Mexico, 1914, p. 159 . 
That there is, on the part of the natives, even in remote corners of the country, a formal devotion is beyond question. Even in the villages of interior Yucatan, miles from a railroad or from anything which elsewhere would be dignified by the name of a wagon road, each oval mud and stake hut has its family altar with its Virgin and such ornaments as its barefoot proprietor and his wife can provide. In such communities, it appears that the church has exercised quite as much influence as the state, which is the more remarkable because of the relations that the two have borne to each other since the Juarez period.

The fact is, however, that in the districts away from the centers of civilization and the railroads neither the state nor the church is a very important factor in the life of the people. The functions of each are formal to a large extent, and skillful agitators can sway the populace to an attack on one as easily as upon the other. Of the two, if anything, the church seems in the weaker position. To be sure, in some states like Puebla, it seems that the revolution surged about the bases of the cathedrals yet, as a rule, left them unharmed; but taking the country in general the churches fell before the hands of the revolutionists with but little popular protest. That so small a minority as that which grasped the standard of revolution in Yucatan, for example, could dominate the population so completely and make them allow, when they did not abet, the general destruction of church property does not show that the church held the position in the lives of the people that the census statistics would indicate. 
The fact is that the church has been held up before the people, since the Laws of Reform, as an influence threatening the life of the republic. It has been used as a bogey by the liberals to support their power and guard against the possibility that the clergy might return to their former position of influence among the people. For a generation and a half at least it has been unimportant as a political influence. There is no Catholic political party and even devoted Catholics have been agreed, at least until recently, that it would be inadvisable to form one. The position that has been forced upon the church by political developments has not only destroyed its political influence very largely, but has undermined its prestige. It has not been able to continue as effectively as formerly its work for the education of the Indian population nor for its real conversion. It is admitted even by enthusiastic churchmen that in the districts away from the larger cities the Indian is reached only in a formal way by educational influences and that to his religion he is attached without an understanding of any but its most simple teachings.

Nor has the church maintained its hold upon the socalled upper class. Formally these too are in large majority Catholic but regular church attendance has admittedly become less general, especially among the men, a large number of whom are more or less openly agnostic.

If, however, the official figures be relied upon to give a picture of Mexican religious conditions, there is little to show that the campaign against the Catholic church by political leaders, the missionary work of Protestant 
churches, or the gradual infiltration of foreign influences have had much effect in this land, which, like others under Spanish dominion, was once Catholic exclusively and perforce. Of the 15,160,369 Mexicans listed in the census of $1910,15,011,176$ were Catholics; 68,839 were Protestants; 6,237, Buddhists; 602, Mohammedans; 630, Greek Orthodox; 254, Israelites; and 5,605 of other faiths. ${ }^{13}$

Even the latest statistics of the Mexican population give no adequate basis on which a statement can be made concerning the general education of the people. The school system is not well developed. Illiteracy is still very high. With the figures available it is impossible to make more than general statements concerning either the total population unable to read and write or the relative illiteracy in different parts of the country. The census of 1910 reports that among the 15,160,369 persons enumerated, 7,065,464 are persons 12 years of age or over who do not know how to read or write. Comparisons of census figures in other countries indicate that the portion of the population less than 12 years of age is roughly one-sixth. This would indicate that the illiterate population 12 years of age or over constituted about 52 per cent of the total. As a basis of comparison may be taken the statement that of the population of the United States over 10 years of age in 1910, 7.7 per cent were reported illiterate. The figures make a

${ }^{13}$ Ibid., p. 155. A good discussion of the church as an element in the social life of Mexico is found in Wallace Thompson, op. cit., pp. 170-194. See also Manuel Calero, Ensayo sobre la reconstruccion de Mexico, New York, 1920, p. 12 et seq., and p. 37 et seq. 
much more favorable showing than those in unoficial estimates. These indicate an illiteracy ranging between 80 and 85 per cent. ${ }^{14}$ Some of such estimates are based on the total population, which is evidently an unfair standard if education is being considered in relation to ability to understand public affairs as presented through the printed page and in relation to ability for self-government. The estimates of many careful observers agree, however, that the census returns, even making all allowances, present the picture in a very favorable light and calculate the illiteracy of even the adult population at near to 70 or 75 per cent.

Whichever standard most closely approximates the truth, it is clear that literacy in Mexico, as elsewhere, if taken as a test of general intelligence must be considered along with the actual amount of reading done by the population, the circulation of books, magazines, and newspapers, and the general intellectual activity of the community. In these respects the life of Mexico, with the exception of that in the cities, is backward, even more so, it seems clear, than the official figures or individual estimates indicate.

Accepting the official figures as a basis for comparison of the relative prevalence of illiteracy in different districts it appears, as would be expected, that the northern states and those in which the larger cities of

14 T. Esquivel Obregón, Influencia de España y los Estados Unidos sobre México, Madrid, 1918, p. 102, asserts that 93 per cent of the voting population of Mexico is illiterate. Jorge VeraEstañol in his Carranza and His Bolshevik Régime, Los Angeles, 1920 , p. 33, estimates the illiterates at "over four-fifths" of the population. 


\section{MEXICO AND ITS RECONSTRUCTION}

the central plateau are located make a better showing than the rest of the country. These are the regions where foreign influence has made itself most felt and where the government supervision of education has been most effective. ${ }^{15}$

The census of 1910 does not classify the population in a way that makes possible more than a very general statement concerning the activities to which the people devote themselves. In some cases there is great detail, as in the enumeration of the single archeologist and the lone apiculturist with which the country is credited. In another case 58,840 persons are lumped as "workers in industrial establishments." The enumeration of the chief classes given in the table below is valuable only for the general picture it gives of the proportion assigned to the larger divisions, and as an indication of the undiversified character of the national economic life.

\section{Chief Occupations in Mexico ${ }^{16}$}

Unproductive, chiefly minors and students..... 5,423,170 Domestic workers .................4 4,673,804 Agricultural workers, including 3,130,402 peons ... 3,570,674 Industries $\ldots \ldots \ldots \ldots \ldots \ldots \ldots \ldots \ldots \ldots, \quad \mathbf{7 2 3 , 0 2 3}$

Commerce, including 236,278 listed as merchants... 275,130 Mining $\ldots \ldots \ldots \ldots \ldots \ldots \ldots \ldots \ldots \ldots . \quad \mathbf{9 5 , 8 7 8}$

${ }^{15}$ The examination of the reports for individual states, however, does much to destroy faith in the value of the educational enumeration. The difference in the percentage of illiteracy announced in various districts seems much less than what must be the fact when the known inadequacy of the school system in some states is considered and seems to indicate that the census must have been taken very carelessly or that the test of what was to be considered ability to read and write was very low.

${ }^{16}$ None of the other general classes includes 100,000 souls. There 


\section{THE POPULATION OF MEXICO}

In point of numbers the foreign-born population is negligible. They do not reflect in even a faint degree the extent to which foreign enterprise and foreign capital have entered the country. Mexico never received from the mother country a great stream of immigrants that in a true sense Europeanized her population nor have other lands greatly contributed. How many there are of the foreign-born or of those who keep their foreign nationality through inheritance though born in Mexico cannot be exactly determined. It is generally estimated at a higher figure than the census indicates, though the official enumeration, in this case, may be more nearly correct than for the people as a whole because the foreigners are generally in the industrial areas where the count is more easily made. In 1854 there were 9,864 foreigners in Mexico who had taken out "Letters of Security," of these 59 per cent were Spanish, 22 per cent were French. English, Germans, and Americans formed about 6 per cent each. A generous estimate of those in the country in 1861 places the total foreign population at $25,000 .^{17}$

All told there were enumerated in the census of $\mathbf{1 9 1 0}$ only 115,972 foreign born and of these only $658 \mathrm{had}$ accepted the nationality of the land of adopted residence.

are evident inconsistencies in classification. Railway workers, for example, are not classified under transportation though sailors are, and under miscellaneous are placed many classes that should apparently go under industries. The figures are from Boletin de la dirección general de estadística, 5, Mexico, 1914, p. 95. A more detailed analysis of occupations in Mexico is given in Wallace Thompson, op. cit., pp. 315-47.

${ }^{17}$ Carlos Butterfield, op. cit., p. 11. 
The foreigner in Mexico is not on the road to becoming a citizen, as is the case in the United States. He is a foreigner and he intends to remain one and that his son even though born in Mexico shall be one. In only about one case in $\mathbf{1 7 5}$ does he who can remain a foreigner become a Mexican. In 1910 of those enumerated who had become Mexicans, a little less than one-third were Spaniards and one-fifth were citizens of the United States. One Spaniard in every 140 became naturalized, one American in every 155. Forty-five per cent of the naturalized citizens lived in the Federal District and 32 per cent in the states along the northern frontier. Eleven per cent lived in Puebla. A naturalized citizen elsewhere in Mexico is a rara avis.

Of the 115,314 foreigners who had kept their nationality 25 per cent were Spaniards, 18 per cent were Guatemalans who had crossed the southern border chiefly to stay in the coffee districts, and almost 18 per cent were Americans. Eleven per cent were Chinese and another 11 per cent was made up of French, Germans, and Cubans. More than half of the Americans resident in Mexico were reported from the northern states, Chihuahua, Sonora, Coahuila, and Nuevo Leon, ranking in the order indicated. ${ }^{18}$

No study of Mexican conditions can show the underlying causes making the republic a problem to itself and to its neighbors which overlooks the elements that have been briefly sketched in this chapter. A varied population, native, mestizo, and white, without a cultural basis

${ }^{18}$ The above figures are compiled from Boletin de la dirección general de estadistica, 5, Mexico, 1914, pp. 18, 32, 39, 53, 65 and 75. 
upon which to create a uniform civilization, living in territory of wide climatic contrasts, of necessity has serious problems to solve.

The population of Mexico is a group of peoples among whom primitive tongues are still spoken by a considerable portion, and among whom the standard of life, even among those speaking a European tongue, is still of a very simple type. They are peoples largely illiterate and among whom literary and professional, rather than vocational, education has been held up as the standard to be sought for. They are non-industrial and, up to the present, as a rule non-industrious. The development of the resources of the country has fallen into the hands of foreigners who, however great the benefits they have conferred upon the country, do not become a part of its political life as well as of its economic life. Those who seek to bring Mexico out of these conditions into the course of the civilization that we have come to know as European have before them no easy task. 


\section{CHAPTER III}

THE GOVERNMENT OF MEXICO: EXECUTIVE GOVERNMENT

Citizens of the United States take a certain pride in stating that the governments of the new world are republican, that they are set up under constitutions, and depend upon popular vote. Probably the great majority, when they make such statements, think of our own political institutions and assume that those of the other republics from the Mexican frontier to Cape Horn are similar in their organization. But republican government, democratic institutions, and popular elections in the sense in which the people of the United States are accustomed to use such terms flourish only under special conditions, conditions that the majority of the republics of the new world have not attained.

Even in the most advanced states the rules under which citizens actually live are determined by the administration of the laws as well as by their spirit; but if republican institutions and democracy mean anything in practical affairs, they mean a rule of practice as well as an ideal to which the leaders of public life profess allegiance. They mean that the standards set forth in the law must correspond at least approximately to those observed in the everyday life of the community, and that neither the executive nor any other part of the government can act contrary to the popular will as ex- 
pressed in the constitution and the laws. In many states of the New World that standard has not been reached -it has not been reached in Mexico.

It is not necessary to review the history of the various constitutions of Mexico to show that there the fundamental law has outlined an ideal standard of action and not a rule for everyday observance. A comparison of the norm set by the constitution of 1857 under which the republic lived through all the orderly period of its existence with the practice of the government in the same period will illustrate the degree to which even in time of peace the observance of the constitution has continued to be an unrealized ambition.

In its main outlines this constitution, like its predecessors, was very much like the Constitution of the United States of America. There was an attempt to establish a division of powers among three branches of the government. The legislative function was vested in a Congress composed of the Chamber of Deputies and the Senate. The members of the former were elected for terms of two years by Mexican citizens qualified to vote, from districts of a population of 40,000 or major fraction. Those elected must be at least 25 years of age, residents of their districts, and not members of ecclesiastical orders. The senators were elected by an electorate qualified as was that which chose the deputies, two being selected from each state. The requirements for candidacy were the same as for the deputies except that the senators had to be at least 30 years old. Their term was six years.

The executive power was centered in the President of 


\section{MEXICO AND ITS RECONSTRUCTION}

the United Mexican States, elected indirectly for term of four years, ${ }^{1}$ and, by an amendment to the constitution of 1857 under date of December 20, 1890, eligible for reelection indefinitely. Candidates for the Presidency had to be native born Mexicans, at least 35 years of age, residents of the country at the time of the election, and not members of ecclesiastical orders. A cabinet assisted the President in the administration of the government. The judicial power was vested in the Supreme Court of Justice and district and circuit courts elected by the people indirectly for terms of six years. The jurisdiction of the federal courts was very similar to that of the federal courts in the United States.

The rights of the citizen against the government were carefully guarded in a bill of rights. All men born in the republic were declared free. Slaves became free on touching Mexican soil. Freedom of thought and of the press were guaranteed. The right of petition was recognized as was the right to bear arms and the right freely to travel in the republic. Private property could not be taken for public use without due compensation, quartering of soldiers in time of peace was prohibited as was search without warrant. Titles of nobility, imprisonment for civil debts, and imprisonment without trial for a period longer than three days were abolished. There could be no cruel and unusual punishments nor

1 The term was made six years in 1904 after "unanimous approval of the legislatures of the States." The final declaration by the Mexican Congress is published in Papers Relating to the Foreign Relations of the United States, 1904, p. 491. The elaborate inauguration ceremonies are described at p. 493 . 
monopolies, except certain ones which the state might set up.

A degree of responsibility was given to the individual states similar to that given the states of the American Union. They had like limitations. In law their governments were described as republican, representative, and popular. They had the same general divisions of powers as the central government. The legislative power in the majority of the states was vested in a single representative body called a Congress. The members, in most cases, were chosen indirectly for terms of two years. The executive power was in the hands of a governor chosen almost without exception indirectly and serving four years. The majority of the states had supreme courts with a system of inferior courts and judges.

In short, the Mexican constitution of 1857 set up a frame of government that had all the nominal guarantees necessary for the establishment of a popular government of the sort that had been created north of the Rio Grande in a sister republic, whose constitution Mexican statesmen, almost without exception, have admired. ${ }^{2}$

The theory of the Mexican constitution was never put into practice in either the central government or the states. The fundamental concept of the division of powers between the three departments was never observed. In the period of confusion between the issuance

${ }^{2}$ A cogent criticism of the influence of the example of the United States upon Mexico is found in T. Esquivel Obregón, Influencia de España y los Estados Unidos sobre México, Madrid, 1918, passim. 
of the constitution of 1857 and the Diaz régime, public and private right were so disturbed that it is useless to attempt a discussion of the degree to which the various leaders sought to observe the commands of the constitution. With the coming of Diaz the theoretic balance of power was lightly brushed aside and an executive government was established that used the legislative and judicial branches as its agents.

One of the leading Mexican newspapers, contrasting law and fact, declared in 1878, "The constitution of 1857 is an ideal law, made for an abstract man; it is necessary to make it a Mexican law, adapted to our present condition and endow the state with all the vigor to recover from the long and dolorous experience of a half century of civil disturbances." It concludes, "legal precept is not in consonance with the necessities of life, arbitrary power and despotism are the only regimen possible in societies like ours." 3 Under the existing conditions perhaps the conclusion was justified and the best that could be done, since the form of the constitution was not changed, was to keep it as an ideal, though not a measure of existing rights. Theoretically, of course, the policy adopted was altogether indefensible. Its justification was that it might keep Mexico from falling to pieces, raise the country in the estimation of the world, and bring to it that solid basis for economic development, which must be the foundation of any consistent national progress. ${ }^{4}$

${ }^{3}$ Quotations from La Libertad in Papers relating to the foreign relations of the United States, 1878, p. 658.

4 See a discussion of federal as opposed to centralized govern- 
The first functions of the government in the opinion of those who supported the new régime were the establishment of order and the collection of funds by which the foreign obligations could be met and property protected at home. Policing and taxing were the most important, and, at first, the only important services rendered. Government as an expression of general public opinion, as a factor in the citizen's life because it was a part of him and he of it, that sort of government did not exist. It was not a spontaneous outgrowth of the national character but something imposed from above by a group, whose control was justified by the acquiescence of a people that had no public opinion organized for determining upon whose shoulders the responsibility of governing should rest. A true republican government could not come into existence, it was argued, by the fiat of a constitution. It could not become an actuality until there was born a public opinion resting on education and common ideals. It could not rise until the diverse elements of which the nation was composed developed a solidarity of interest founded on a better basis than common oppositions and the accidents of history.

The degree to which the policing function demanded and received the attention of the government is reflected in the appropriations for military expenditures throughout the Diaz régime. This was a period after the two invasions by foreign troops that the republic has suffered. It was one in which the military problems were

ment in Mexico, by L. S. Rowe, Annals of the American Academy of Political and Social Science, vol. 54, p. 226, July, 1914. 


\section{MEXICO AND ITS RECONSTRUCTION}

almost exclusively domestic yet the army continued to figure largely in the national budget.

In the late '70s the federal government maintained an army of 30,000 men whose demands required twofifths of the entire revenue. Notwithstanding this the chief item of expenditures of the states was also for military purposes. These forces, usually called state guards, might be expected to be necessary in the outlying regions where the arm of the national government could not be relied upon. In fact even populous states near the capital maintained them. The State of Mexico itself spent about 30 per cent of its revenues on its soldiers. Puebla, Jalisco, and others among the more advanced of the Mexican units did the same. ${ }^{5}$ Doubtless these local forces were at times needed for policing purposes, but their existence made the raising of a revolution against the national government easier. It was the natural impulse of the central government to bring them under its own control as far as possible in order fo minimize the chance that its own power might be questioned.

Commenting on a report made to the federal Congress by one of its members a Mexican editor analyzes governmental conditions in $\mathbf{1 8 7 9}$ as follows : ${ }^{6}$

The vast territory of this country is in its greatest part divided into petty kingdoms, subject to the whims of little local tyrants, who inflict upon their unfortunate subjects every class of outrage and vexation. Neither life nor property, nor any of the other individual rights, have guarantees of any kind; of

${ }^{5}$ Papers Relating to the Foreign Relations of the United States, 1879 , p. 835 et seq.

'Ibid., p. 826 et seq. 
the administration of justice there exists nothing but a vain pretense, and public morality has passed into the category of unrealizable dreams.

To remedy such conditions President Diaz at once set his hand. The army was the instrument on which he relied. One of the developments with which he was best satisfied at the end of his first term was the "great and undoubted progress ... made in the organization of an efficient police, both metropolitan and rural; the latter being distributed not only in the federal district but throughout the various states of the republic." ? Throughout his period of control the President continued to rely on the military power as the factor that should keep the nation in equilibrium.

The emphasis of the policy of policing the country by forces increasingly under the control of the central government, of itself emphasized the executive functions of that government. The ignorance of the people and their inexperience in self-governing institutions prompted doubts as to the possibility of truly popular elections and as to the advisability of entrusting more than the form of power to legislators or judges who might be selected by them. As a result, to protect itself, the executive and the small circle that surrounded him came to consider it a necessity not only to control the administration local and central, partly through the political organization and partly through the army but also to take from the legislature and the courts any real

${ }^{7}$ Paraphrased from address of President Diaz to the Mexican Congress in ibid., 1889, p. 553. 


\section{MEXICO AND ITS RECONSTRUCTION}

freedom of action. 'These became bodies that in practice registered the will of the administration.

Even though a state has not a people who have risen to conditions that may make a true popular government possible, it may have a constitutional government if the small governing class is organized for expressing its own divisions of sentiment and disposed to respect the provisions of the constitution by abiding by the decisions so expressed. Mexico has not arrived at that status. Admirable as are the intellectual qualities of the upper-class Mexican, he has not yet developed a spirit of coöperation and forbearance which leads him to comply with constitutional standards in the choice of public officials even by the small class to which he belongs. $\mathrm{He}$ has not shown a willingness to give obedience to the standards that the opinion thus narrowly determined demands. Unfortunately for Mexico her political life has seldom indeed risen above a camarilla stage and the ruling camarilla has seldom been strong enough to control the man who for the moment was at its head.

No government in power in Mexico in the old régime ever failed to control the elections that it called. To be sure there were dissenting groups that did succeed not infrequently in defeating the government candidates in the Congressional elections but they never rose to the dignity of true parties and their success could have been cut down doubtless had the administration felt it necessary or politic to do so.

Even a class government may be a step toward democracy. Mexico, properly speaking, has never had a governing class. She did not have it under Diaz and 
the failure of the dictator to take effective steps to create either a governing class that could fight out within itself the national policies, or a popular educational system that would prepare the people as a whole for selfgovernment was a signal failure of the government he created.

Under the old dictatorship Mexico drifted on into the twentieth century, into a century in which the changes that had come in her national life and her shortcomings both stood out in sharp relief. It was a new economic Mexico with railroads, telegraphs, newspapers, and an increasing number of foreigners, all of which brought enlightenment through touch with the outside world. But among the advantages that had come from the new day, ability in self-government was not numbered. Economic improvements had been introduced from abroad and had become a vital part of Mexican life. But the political training of the people was given no attention.

In the actual problems of ruling themselves, the rough give and take of political contests properly so called, the Mexican at the winning of independence was still fairly comparable to the Mexican of the conquest. He had seen the light, wanted to follow the ideals that republicanism and self-government stood for in other countries, but he was almost totally inexperienced. To say that in the interval between independence and the beginning of the twentieth century the Mexican had made no advance in self-government would be unfair but it is true that he had not markedly improved his position. Republicanism and self-government had come 
to mean more in 1912 than they did in 1812 but, relatively speaking, the Mexican people were little if any nearer the standard set by the leading self-governing peoples of the world after a century of independence. Disorder followed by dictatorship had hindered the development of true political institutions or the successful adoption of the examples offered in the experience of other nations. The Mexican had advanced in matters of government but had not gained on the leaders. He had buffeted through a long list of revolutions but without a broadly constructive political experience. He had developed political leaders but no political parties.

The degree to which the government of Mexico was executive can be appreciated by analyzing the way in which public authority was exercised in the first years of the twentieth century-a period when the power of the old régime was well established and when continued peace had developed what for Mexico could be considered normal conditions.

Power continued to rest in the hands of the President of the Republic as it had rested in the hands of the executive in the colonial period. In practice the President controlled the elections, he determined thus whether he should succeed himself and who should constitute the legislatures, federal and state. ${ }^{8}$ To him the obedient Congress gave power to legislate by decree on specific

${ }^{8}$ In some cases in the latter part of the Diaz period there seemed to be the elements of an independent party organization. The most important was the development under the leadership of Bernardo Reyes in the north. Sporadic defeats elsewhere in local elections were not unknown. 
matters or on entire subjects, or it passed, with only a show of discussion, the drafted legislative measures submitted to it by the President.

The exercise of these wide powers by the executive did not originate with Diaz; it did not end with his fall. By decree even such fundamental matters as tariffs and other forms of taxation were decided upon by the dictator and the same method has been followed by his successors. Congress abdicated to President Diaz the power to issue in his discretion bonds against the credit of the state. ${ }^{9} \quad$ By his authority a controlling interest in railway lines was acquired, Congress merely giving its assent after all the details were arranged. In a word, the powers of Congress had never been recognized as of the nature and extent that the constitution outlined. They had not atrophied, for they had never truly developed.

The Congress, in fact, was never independent either in personnel or in powers. ${ }^{10}$ It was a body composed largely of persons who did not live in the districts they represented, a gathering of carefully selected men often of decided oratorical powers, a dignified body in which true clash of opinion occurred only on such matters as were indifferent to the executive. ${ }^{11}$ Some, at the time

${ }^{9}$ A similar power was conferred upon President Carranza.

${ }^{10}$ The constitution is considered by many to have contemplated legislative ascendancy. See R. Garcia Granadas, La Constitucion de 1857 y las leyes de reforma en Mexico, passim.

${ }^{11}$ A description of the way in which opposition sentiment was controlled early in the old régime is found in the Nation, vol. 41, p. 394, November 12, 1885. See also T. Esquivel Obregón, op. cit., passim. 


\section{MEXICO AND ITS RECONSTRUCTION}

of their election, were already state or federal officeholders and by the vote of the indulgent Congress to which they had been chosen were allowed to hold both the old and the new offices at the same time.

The courts have never been a coördinate part of the government in Mexico, though that has regularly been an announced ideal. The federal judges under the old constitution were nominally elected and those of the state courts were generally chosen by the governor. In any case, the executive, state or federal, regularly controlled the selection. Since the federal executive had influence in the choice of the governors of the states, the courts from the highest to the lowest, in practice, were his own creatures.

In its treatment of the courts in the latter part of the Diaz régime the executive seems to have found itself drawn between conflicting impulses. The President was urged by certain of his advisers to make the ideal of an independent judiciary a fact and it is alleged he desired to do so. $\mathrm{He}$ is said to have hesitated to put property rights under the unrestricted control of the courts because of the unfortunate effects both national and international which such a step might involve. From the national point of view it was of the greatest importance that the flow of foreign capital into Mexican investments should not cease. If anti-foreign prejudice in the courts, especially the local courts, produced decisions that would discourage investment, it was argued that the economic development of the republic would be hindered. Furthermore if foreigners were denied justice, they might take their claims to their own 
governments with diplomatic complications as a result. If the executive kept an effective control over the courts, such unfortunate circumstances could be avoided. The traditional policy of concentration of power, so far as it affected the courts, could be bolstered evidently with arguments of a concrete character. To the end of the Diaz régime the often promised freedom of the judiciary remained an unrealized ideal.

The fact is, then, that the government of Mexico, when it has deserved that name, has been an executive government. When the executive has been responsbile and has had effective control, life and property for citizens and foreigners have been safe. If the executive has become irresponsible, life and property have been insecure. When the executive has lost control, Mexico has become a geographical expression and not a government. ${ }^{12}$

${ }^{12}$ An article describing the development of executive control in the Gonzalez period is found in the Nation, vol. 34, p. 399, May 11, 1882. The executive influence exercised in modifying the constitution before the last election of Diaz is described in the Nation, vol. 78, p. 448, June 9, 1904. 


\section{CHAPTER IV}

THE GOVERNMENT OF MEXICO: ELECTIONS

Tracing the details of Mexican politics before the Diaz régime gives no picture of principles or system. Each triumph announced is followed at a short interval by what appears to be the overthrow of all the triumph stood for. Nor indeed did the government, which brought peace in the late ' 70 s, mean triumph of principle. Of the principles for which it stood-no reëlection and free suffrage-one was overthrown by the leader who proclaimed it and the other never was given a trial. There was established a system of government that brought peace, freedom from pillage in the name of the people, and at least a greater measure of freedom for the economic development of the country, but the political ideals of the revolution were brushed aside and ignored.

How Mexico came to the belief that peace at any price was the first need of the republic is the theme of a great part of its early history. In the generation following the revolution against Spain the contests had been between the Conservatives, or supporters of the church, and the Liberals. These were divisions on principle but ones in which the conflicts of opinion were settled, as a rule, by violence and not by appeal to the ballot. At the restoration of the republic in 1867, the French intervention having come to an end, the Liberal 
party was completely victorious. Its opponents have never recovered their prestige, nor indeed have they even attempted actively to enter political life. Juarez was elected President on the prestige of his leadership against the Conservatives and the European intervention. There was practically no opposition. A large minority of the people constituting the Conservative party had eliminated itself as a political factor.

At the next election the single group that was left divided into the supporters of President Juarez, Lerdo, and Diaz. The discord that had formerly existed between the parties invaded the organization of the Liberals. Even the general participation of the Liberal party in politics was soon to disappear. In the election Juarez was again declared President. Diaz appealed to arms in the so-called revolution of La Noria. With the revolution still in progress Juarez died. Lerdo, in accordance with the law, succeeded and later was elected without contest-and with very little popular participation. The Liberal party, so far as it had vitality, was breaking down.

In the election of 1876 Lerdo again declared himself a candidate. Diaz announced that an election would be a farce since Lerdo controlled the election machinery. His supporters took no part in the election but started the revolution of Tuxtepec on the platform "no reëlection and free suffrage." The Lerdistas held their election in July, armed opposition being in full swing and the Conservatives not voting. The revolution headed by Diaz was successful and its leader ordered a new election for President and members of the supreme 
court early in 1877. In this only the Diaz men voted. The other branches of the Liberal party and the Conservatives abstained. The election of Congress the following year showed no more vitality.

The new system of Mexican politics had been ushered in. It was a brave show of popular government but one in which the people had no real part and took no real interest. It was not even a true contest among the upper class. It was a procession only, not, in fact, a struggle in which high aspirations were announced by rival candidates for the approval of the multitude but a sham display in which decisions already taken were confirmed. From 1877 to the end of the Diaz régime elections in Mexico were not functions reflecting national opinion but ceremonies consecrating the established order.

It is wrong to suppose that the succeeding elections in Mexico all rested on active general display of force. They did not, nor was comment in the press at an end. The criticisms of the government in the opposition papers were often lurid. Mexican journalism is nothing if not colorful. But active repressive measures were unnecessary as a rule because there was no active opposition. Peace had come, a peace that, laying its strong hand upon the people, took away from them the right of self-government, which they had used only to abuse it. Peace had come to bring to the country the longed for economic development that might make Mexico one of the leading countries of the New World. Pity that the peace that came to Mexico had not also within the folds of its garments that uplift for the Mexican people 
that would have made them capable of solving by peaceful methods the very problems that peace and material development left at their door!

The election of 1882 illustrates the conditions at the beginning of the new régime. There were no true party organizations, practically no public gatherings, and little discussion of candidates or issues in the press. There were no nominating conventions. The candidates were chosen in private juntas of very select character. High flown editorials appeared concerning the solemnity of the electoral function but even the date of the election passed almost unnoticed and the announcement of the result was not of sufficient public interest to receive more than casual mention. ${ }^{1}$ Even the solemn public show of compliance with constitutional formulas, which characterized the later "elections," was not observed. Mexican leaders seemed to have tired of factional struggles and were willing to let the government in power rule-if it could assure peace.

By its organization the electoral system in force contributed to make it easy to impose the will of the party in power. It was so complicated that it obscured the

${ }^{1}$ A good description of political conditions during the election of 1882 is found in the Nation, vol. 34, p. 399, May 11, 1882, and the Nation, vol. 35, p. 198, September 7, 1882. These articles discuss the conditions under Gonzalez. The conditions surrounding earlier elections are described in Papers Relating to the Foreign Relations of the United States, 1878, p. 567 et seq. Later elections are described in Alfred Bishop Mason, "The Cause of Revolution in Mexico," Unpopular Reviere, vol. 3, April, 1915, and Henry Lane Wilson, "Madero's Failure," Annals of the American Academy of Political and Sociah Sciencce, vol. 54, p. 148 et seq, July, 1914, discussing the government control of elections under Madero. 


\section{MEXICO AND ITS RECONSTRUCTION}

result of any development of popular opinion. ${ }^{2}$. While a system in some respects similar has resulted in the United States in an approach to direct popular control through the creation of agencies which, while keeping the form of the constitutional provisions, changed their spirit, in Mexico the indirect system enabled the executive to destroy all popular control.

The various states were divided into electoral districts of 40,000 inhabitants. These in turn were divided into sections of 500 inhabitants. Every alternate June the people of a section chose an "elector." The electors assembled in July to vote for one Congressman for each district and two Senators for each state. Every fourth year they voted also for the President. The result of the voting of the electors was canvassed by the Congress in the case of the Congressmen and the President, and by the State legislatures in the case of the Senators. ${ }^{3}$

The state elections, also based on popular vote, occurred simultaneously with the choice of the federal officers but aroused no more popular interest. The state officers were regularly supporters of the government who lived in the state capital, though representing, in the case of legislative officers, outlying districts in which they were often very little known. Often the members of the state legislature might also be executive officers.

Besides this practice of allowing an individual to hold

${ }^{2}$ Papers Relating to the Foreign Relations of the United States, 1878, p. 567 et seq.

${ }^{3}$ Various amendments were introduced before the end of the Diaz régime, but the general character of indirect choice was not affected thereby. 
executive and legislative positions at the same time, there grew up the custom of divorcing representation from even the requirement of a nominal residence in the district represented. This was true in both the state and central governments. The law required that members of Congress should be citizens and residents of the districts represented. Nevertheless it frequently happened that those elected were neither, and in some cases had never even been physically within the district from which they were "elected." Curious situations arose thus. In 1878 one of the prominent members of Congress was elected from a district in his native state but not that of his residence. He was also chosen from a district in another state. As he was at outs with the local governor he accepted the election in the second. At the next election he was chosen Senator from a still different state and seated.

These practices continued throughout the Diaz régime. In 1904 three states were represented in Congress by Senators and deputies none of whom had ever resided in their districts and only two or three of whom had ever been in the states they represented." Actual residence, even when claimed, was, in fact, often nominal since the real abode of many of the representatives was regularly the capital-the attractions of which made life in the provincial towns seem dull.

As the Diaz period progressed the elections became more important events in the national life. They were given greater publicity and attracted more popular attention. Nevertheless they did not represent a clash be-

${ }^{4}$ Nation, vol. 79, p. 194, September 8, 1904. 
tween two great political parties nor a free-for-all contest between a number of groups. There was no political organization such as is characteristic in AngloSaxon countries and in continental Europe.

The election of June, 1904, illustrated the smooth working of republican government of the type the Diaz administrations created. Election boards were chosen in strict accordance with the letter of the law and polling places were specified. In the campaign period there were "spontaneous demonstrations of the masses" announced by government papers. Small crowds gathered at political speeches to enjoy the music that was furnished and to be thrilled by oratorical appeals to general principles. On election day there was little real public interest evident. When the votes, which in most districts were few, were counted, the candidates who had been announced as having the support of the government were found elected. They had had little opposition, indeed they generally had no opponents.

The election over, the work of the various electoral colleges proceeded with all due ceremony. The following summary is based on the official proceedings of one such body as published in the official Gazette of the State: ${ }^{5}$

At the first meeting, the jefe politico, or governor, of the district presided, until the meeting, composed of sixty-odd electors, had chosen its officers, after which he withdrew and the meeting adjourned for the day. At the second meeting, the "credentials" of the members elected ... were all pro-

${ }^{5}$ The facts concerning the elections of 1904 are taken from the Nation, vol. 79, p. 194, September 8, 1904. 
claimed correct, and the meeting adjourned. At the third omeeting, a Deputy for that District and a Senator for the State were chosen, by unanimous vote, together with a substitute for each. The fourth meeting brought out the vote for President and Vice President. Diaz was unanimously chosen, after which a telegram of congratulations was sent to him, and felicitations were exchanged with the Governor of the State during an informal recess; then Corral was voted upon for Vice President, receiving 50 of the total of 66 votes, the rest being a few scattering expressions of individual choice. At the last meeting the two justices of the Supreme Court . . . received formal approbation. Thus, five days, with sessions of an hour or less each, were consumed in the process.

By this time repression of public discussion in the spoken word or in the newspapers had almost disappeared. ${ }^{6}$ The dictator in the latter part of his régime is said to have welcomed criticism so long as it did not touch himself. Whether this was done from desire to promote the development of true parties, which might later become responsible agents for carrying on the government, or as a means to provide a safety valve for increasing public opinion is not clear. There was, however, no group of thinkers that announced a platform of real reform. The opposition press was no more constructive in policy than that which supported the gov-

${ }^{8}$ The control over the casting and counting of votes, however, was not lessened and extreme measures were taken when an election threatened to become more than a formality. See an interesting discussion of widespread arrests and other corrupt practices employed to control the Diaz-Madero election, in Dolores Butterfield, "The Situation in Mexico," North American Revierw, vol. 196. p. 649, November, 1913. 
ernment. The statements of the papers presented the most amazing contradictions. The work of the reporter and of the newspaper in the elections too often were interpreted not as involving a duty to report the facts but as an opportunity to damage the candidate opposed by misstatement and invective.

The degree to which popular government did not exist in Mexico in the old régime may be judged by the number of votes actually cast for the Presidential candidate. Going back before the Diaz régime we find the votes at the second election of Juarez to number 12,361 in a reported population of $8,836,000$. Lerdo was chosen in 1872 by 10,465 votes with less than 1,000 in opposition. The control of the government in 1876 was determined by revolution. In $1880,11,528$ votes were cast for Gonzalez with a scattering opposition. ${ }^{7}$ Popular interest did not rise even with the establishment of peace. Throughout the Diaz régime there continued the apathy on the part of the general electorate which must be shaken off before Mexico can lay any claim to being a representative or popular government.

Since the passing of the old régime no issue has been presented to the people under conditions that would encourage a free expression of popular opinion. The private instructions sent out for the Huerta election in 1913, which was the veriest farce, showed on their face the desire to preserve an apparent respect for popular will and to assure that it should be defeated.

Political parties and citizens were to be "given full freedom in the polls which may operate, allowing them

'Figures cited in the Nation, vol. 34, p. 399, May 11', 1882. 
to make all kinds of protests, providing they refer to votes in favor of any of the candidates appearing before the people" and those who were chosen to manage the polls were to be persons who would "inspire absolute confidence" and who were "well versed in the electoral law."

The private instructions sent out provided, it is reported, that the persons in charge of the polls were to be "absolutely reliable, so that they may follow the instructions given to them." It was planned to prevent, where possible, the election in two-thirds plus one of the polls in each district, to make the choice void. In all the polls that did operate blank tickets were to "be made use of in order that the absolute majority of the votes may be cast in favor of General Huerta . . ." and if these means failed the returning officers were to falsify the result. ${ }^{8}$

The government recognized in the election of 1917 that the executive influence exercised in the elections of the old régime did not square with true democratic standards and announced its intention to have the voting unaffected by official pressure. First Chief Carranza announced that the reports that some of the candidates for governorships were official candidates were unfounded. He declared "the Constitutional government, which I have the honor to represent, will not sustain or protect any popular candidate whatsoever. . . . In virtue of this in some of the States, where the provisional

8 This interesting set of directions, dated October 22, 1913, is published in the Congressional Record, vol. 51, part 9, p. 8517, May, 1914. 
governors have placed their influence in favor of certain candidates, they have been removed, so that the will of the people shall not be trampled upon." " Whether the election was free in fact is disputed. The opponents of the government alleged that the announcement that the election was free was made only to strengthen the government in the opinion of foreign nations.

It seems clear that in some sections at least the election of 1917 did awaken a greater interest in public affairs, and resulted in more voluntary voting. In some cities activity in the election appears to have produced spirited contests, ${ }^{10}$ but these seem to have been generally the result of enthusiasm in support of rival candidates within the same party and not of a true inter-party clash. In Mexico City there were over $\mathbf{6 0 0}$ candidates for the 24 positions to be filled - a fact which in itself shows scattered enthusiasm rather than good political organization. The official Congressional canvass showed 797,305 votes cast for Carranza, 11,615 for Gonzalez, 4,000 for Obregón, and a number of scattering ballots for other candidates. ${ }^{11}$ On the evidence available it appears clear that the election of 1917 was

${ }^{9}$ Mexican Review, vol. 1, No. 9, Washington, June, 1917. The announcement was dated at the National Palace, Mexico, April 7, 1917.

${ }^{10} \mathrm{~A}$ description of this election is found in the semi-official Mexican Reviere, Washington, vol. 1, No. 8, May, 1917. See also Arthur Ruhl, "Mexico's First Real Election," Collier's, vol. 48, No. 7, p. 19, November 4, 1911.

${ }^{11}$ Mexican Reviere, vol 1, No. 9, Washington, June, 1917, p. 3. A table is included showing the votes by states. See also Bulletins of the Mexican News Bureau, June 19 and 21, 1917. 
less affected by official influence than those of the old régime. There was greater popular enthusiasm and the largest vote in the history of the republic was cast.

On the other hand, the circumstances surrounding the election were so exceptional that the returns cannot properly be taken as indicative of what may be expected in the average case. The choice occurred shortly after a successful revolution, when a widespread opposition could hardly be expected. This was the first election in which the Mexican people voted under the new constitution providing for a direct vote for the President, a change which in itself would encourage a heavier poll. The desire of the administration to make a good showing naturally made its supporters anxious to get the voters to the polls. The opposition did not vote. Many of its leaders were in exile. The government could have made the vote larger doubtless if it had wished, just as the Diaz government could have increased or decreased the polling if it had been felt worth while. The lack of secrecy of the ballot, especially among a population so largely illiterate, is another factor that makes the result doubtful as a reflection of the popular will.

Events after the election of $\mathbf{1 9 1 7}$ have not been encouraging for those who hope for the early development of popular elections in Mexico. The violent death of President Carranza followed, after the provisional Presidency of de la Huerta, by the unopposed election of Obregón in August, 1920, does not show that a new era in Mexican politics is at hand.

The most unsatisfactory feature of these elections is 


\section{MEXICO AND ITS RECONSTRUCTION}

their unanimity. No nation of $15,000,000$ people voting under normal conditions shows such community of opinion. There was not before the revolution and there is not now in Mexico a vigorous party organization that brings a clear-cut clash on candidates and policies. The test of the Mexican people as a voting body lies not in the elections of 1917 and 1920 but in the elections to come, when the personal ambitions and differences of opinion of the various leaders have free play. There may then arise the old personalism that has been the fatal element in Mexican politics. The mutterings of discontent already beginning to be heard may make applicable again the lament of a member of the Supreme Court who, over a generation ago, declared: ${ }^{12}$

We have frequently asked ourselves what the divisions of the Liberal party in Mexico signify. Proclaiming the same principles, entertaining the same aspirations, united in the same history of abnegation and sacrifices ... the numerous members of this great family have separated ... when they should ... combine their efforts and unitedly advance to the attainment of a great object, the progress and prosperity of the country. ...

Many times, we have asked ourselves, is reconciliation among the different members of the republican family possible?... And in case of the absence of sufficient abnegation for the consummation of so meritorious a work, what is the fate which awaits, not merely a certain political organization, but the country disunited, debilitated, impotent to control the disorder which consumes it ... . ? If the contentions of personal fac-

${ }^{12}$ I. M. Vigil in Monitor Republicano, August 7, 1878, article quoted in Papers Relating to the Foreign Relations of the United States, 1878, p. 571. 
tions are to continue as up to the present, ... . it will neither be possible to establish a durable government nor to restrain crime which, under a thousand forms, may invade society, the country being condemned as it seems to inevitable dissolution.

One cannot study the political history of Mexico without reaching the conviction that the political leaders have not faced the facts with which they have had to deal. There has never been a determined and united effort to raise the people to that status in which true enthusiasm and ability for self-government is born. The better educated have made sporadic efforts to do so but those efforts have broken down almost as soon as made. Great advance has occurred in economic lines through the coöperation of the foreigner. Mexicans have not had coöperation from outside the country in political affairs and have indicated their unwillingness to accept it. If Mexico is to work out her own political salvation, as all her friends hope she may, a great responsibility rests on that small class which, by its wealth, social position, and education, is free from the limitations that surround the electorate as a whole. Orderly government has heretofore meant one-man rule in Mexico. That basis must be broadened, to include de jure and de facto at least those who, by education and experience, have the intellectual equipment for selfgovernment.

Before those to whom Mexico has given advantages lies this opportunity for patriotic service and upon them rests the responsibility of learning the lesson of coöperation-coöperation with those of like and of unlike political faiths. They, must lead their country and must 
govern it, they must prepare the common people of Mexico to discharge the duties of self-government, which a century of experience has shown they do not yet possess.

The failing of Mexican statesmen in the past has been the one that has beset Latin American countries generally from the day of their independence. They have not realized that true ability for self-government on the part of the people at large comes with the slow growth of national ideals and the gradual adjustment to more advanced standards of political thinking and action. The constitution makers have placed their faith in forms of government. They have overlooked the fact that high sounding phrases cannot at a stroke endow a people who have never enjoyed self-government, and who are without experience, therefore, in its exercise and without the critical public opinion on which it must rest, with the abilíty to cast off the past like a cloak and start anew.

This is the fundamental truth that makes all the detailed comparisons of the old and new constitutions carried on in and out of Mexico futile. The old constitution did not fit the facts. The new constitution does not do so. The people of Mexico will never truly rule themselves until the day when by evolution through education, industry, and habits of political association they fit themselves to do so. ${ }^{13}$ Unfortunately the adop-

13 The political organization considered practical by the advanced revolutionary leaders is discussed by V. Carranza in his "Report to Constitutional Congress at Querétaro," December 1, 1916, New York, Latin American News Association (pamphlet). 


\section{MEXICAN ELECTIONS}

tion of no constitution alone will give them that endowment. Till this slow development is under way political power will rest in the hands of some new Diaz or in the hands of a small but widening group, which, with or without foreign aid, will undertake to prepare the people for responsibilities of self-government. 


\section{CHAPTER V}

THE GOVERNMENT OF MEXICO: THE STATE AND LOCAL GOVERNMENTS

THE constitutions of Mexico have attempted to set up states with a sphere of action in large degree similar to that of the states in the United States but the system has never taken root. There has never been a vigorous system of local self-government. Public opinion, here as in the central government, has been inactive and unorganized. The absorption of functions by the central government left the localities little to do. The choice of local officials in the elections was seldom more free from the influence of the central executive power than was the selection of members of Congress and the same influence exerted after the elections made the deliberations of local bodies trivial. They did not have sufficient freedom of action, nor sufficient command of funds to put through the legislation needed by their localities or to arouse public interest in their proceedings.

Most of the state legislatures consisted of a single house of from 12 to 30 members. Their sessions under the old régime were normally two per year, each lasting nominally three months. On the days when the houses met, the sessions were ordinarily limited to two hours. Their proceedings were often brilliant, and the members were often exceptionally able parliamentarians. When 
the legislature was not in session, it was represented by a permanent deputation whose announced function was to protect the rights of the legislature from encroachment by the executive.

Public revenues could be increased only with great difficulty in most of the states. The central government monopolized the customs duties as a matter of course. Since the industrial development of the country was small, the states had in their power to tax local developments, a less valuable resource than in better developed lands. The desire of the states and that of the national government would naturally be to burden enterprise as little as possible in order to encourage the entry of capital. Thus they hoped to create greater local wealth, raise the national standard of life and increase the ability of the government to collect greater amounts in taxes without checking the advance of the country.

The taxing system actually in use had its origin in the system developed in Latin countries long before the period of independence. With some exceptions the rate of levy was low. There was in all the states, except Yucatan, a general tax on property, usually reckoned on a percentage of value officially determined for different classes of real estate. Taxes on industry and commerce were general throughout the republic. Both these levies are alleged to be based on practice introduced into Spain through the Roman law. There was a tax on professions, called the patente, drawn on the model of a French tax instituted in 1791. Consumption taxes on various articles were collected, familiar in 
the colonial period as the alcabala. When formally abolished, these were, in later Mexican history, substituted by municipal duties and an increase in the quotas of other state taxes. Some states had poll taxes or taxes on all persons over 14 years of age. They were not an important source of income. ${ }^{1}$ Besides these there were a large number of other sources of revenue, few of which gave important yields, many of which were survivals, and some of which were merely curious. How weak the state governments were financially may be illustrated by the fact that for the government of the great area of the State of Chihuahua there was collected even as late as 1907 only $\$ 1,307,489$ Mexican, an amount that was even less than it appears, for the services performed by the municipalities in many other countries are largely performed by the state in Mexico. ${ }^{2}$

Weak as the state governments were, they were much stronger than those of the municipalities. In fact just as the central government absorbed the functions of the states, these in turn took over municipal services. No feature of Mexican public life shows more clearly the lack of real self-government in the republic than the condition of the cities and towns during the Diaz régime. It is almost axiomatic that where a vigorous local public life is found there is good soil for the growth of self-governing institutions, the foundation

${ }^{1}$ Memoria de hacienda y crédito público . . . 1 de Julio de 1910 a 30 de Junio de 1911, tomo 2, Mexico, 1912, p. 657 et seq.

${ }^{2}$ Memoria de hacienda y crédito público . . . 1 de Julio de 1909 a 30 de Junio de 1910, Mexico, 1910, p. 719. This document contains an excellent analysis showing the various sources of state funds. 
upon which a strong and effective public opinion and public authority may be raised. Mexico has never enjoyed that blessing.

Local government, as a result, lacked reality and seriousness; it was not a vital part of the life of the community. Democracy was dead at the root. Town feeling became sentimental not fundamental. The most evident and often the most important work done by the local government was the furnishing of entertainments, such as band concerts and the maintenance of a municipal theater. Financial difficulties brought it about that the water supplies of the larger towns, with the exception of that of the capital, as a rule, were put in by the state governments which kept a control over the rental charges so as to be able to pay for the expenditure. In some cases the apathy of the local population toward their own interests forced the adoption of control by the larger units if certain services were to be performed in more than a farcical manner. In Jalisco, for example, the state government found itself under the necessity of administering the schools and poor relief because the local government was too weak to do so. ${ }^{3}$ The states of

${ }^{3} \mathrm{~A}$ good criticism of Mexican local government is found in L. S. Rowe, "Notes on Municipal Gevernment," Annals of the American Academy of Political and Social Science, vol. 21, p. 532, December, 1903. See also C. W. Dabney, "A Star of Hope for Mexico," New York, Latin American News Association (pamphlet). The reasons for the decay of the municipal government system introduced by the Spaniards and of the local government that the Indian communities had developed are outlined in T. Esquivel Obregón, Influencia de España y los Estados Unidos sobre México, Madrid, 1918, pp. 213-226. 
Durango and Michoacan, at the end of the first century of independence, did not collect any municipal taxes."

There was little freedom of action allowed the cities. Their small budgets had to be submitted to state authorities for approval before they could go into effect. In most states the same was true of all the more important municipal decisions even if not of a fiscal nature.

There were some variations in local government but the municipality had no wide range of organization such as we are familiar with in the United States. The ayuntamiento, or town council, was elected by an indirect system. The people voted for electors who in turn chose the councilmen. The powers of the council were largely deliberative. The real executive officers were not under its direction or control. The municipalities regularly had but small power to raise money. They could not undertake important public works.

The general character of their income may be illustrated by the list of taxes levied in the municipalities of the State of Aguascalientes at the end of the first century of Mexican independence. It comprised levies on irrigation, public amusements, slaughterhouses, stables, vehicles, professional licenses, weights and measures, rentals, on fattening hogs, bandstands, pawnshops, buildings in construction, restaurants, stands or chests in the portals of churches, gambling places, warehouses, saloons, lotteries, firearms, traveling salesmen, checks, and certain classes of peddlers. ${ }^{5}$ Some of these branches

4 Memoria de hacienda y crédito público . . . 1 de Julio de 1910 a 30 de Junio de 1911, tomo 2, Mexico, 1912, pp. 216-23.

- Ibid., p. 221 et seq. 


\section{LOCAL GOVERNMENT}

in a country better developed might have been made important sources of revenue. They were not in Mexico.

The most important link between state and municipal governments and the chief means by which the former came to control the latter was the jefe politico, the political chief, appointed in each municipality by the governor and responsible to him alone. In some cases, as in Morelos, these officers came to be formally recognized as the presidents of the municipal councils. In their hands rested the execution both of the general law and of regulations passed by the municipal councils. They were thus Janus-faced officers who had duties in two directions but who in practice could be held responsible only by the state functionaries.

Their double position and the very wide and largely unwritten powers which they came to exercise made them one of the chief reliances of the Diaz system of actual government. An able and benevolent official could do much to assure order, contentment, and progress in his district. Unfortunately a bad one who, through the inertia of the higher officials or corrupt influences could count on the support of the state and national military forces, might become an oppressor very difficult to call to account or remove.

In the later years of the Diaz régime the jefes politicos became the subject of widespread criticism. How great the abuses came to be it is hard to determine. That there were many instances of wrongdoing sheltered by these officials is beyond doubt. They seem to have been in some districts the chief stay of the peonage 


\section{MEXICO AND ITS RECONSTRUCTION}

system. It was to be expected that when the old régime came to be called to account the office of the men who governed in the locality but were not subject to its will would be one of the points of attack. The revolution promised to do away with the jefe politico and to set up the free municipality.

The new system of local government that it is sought to introduce starts out under far from favorable conditions. The political inertia of the local population in the great majority of municipalities is a heavy handicap. Centralization is such a well established tradition, acquiescence in a government imposed from above has gone on so long, that it will be difficult to arouse the cities and towns into a vigorous life. A steady and uniform advance in municipal government is too much to expect.

No one who walks through the streets of a Mexican town off the line of the great trunk railroads can be enthusiastic as to the prospects of success of real local government in the immediate future. There will probably be many backslidings and the standard, which the enthusiasts of the present reforming government speak for, will not be achieved in their day nor in that of their grandchildren. But, whatever their errors in other directions, there will be little doubt in the minds of most of Mexico's friends that the revolutionary statesmen are standing on bed rock when they insist upon the importance of creating a keen interest in local government and the problems associated therewith.

The municipalities are the first school of government. Within these units, involving such simple problems as 
will be dealt with by the average Mexican city, mistakes can be made with comparatively small harm while political experience is being gained. Through experience in self-government in the towns there may be built gradually the foundation of a new Republic of Mexico, a republic of greater stability and strength than the one that rested on economic advance alone. Whether Mexico can build such a state from its present population may be doubted even by the friends of Mexico but there can be little doubt that if it can be built, the foundation stones must be laid in the municipalities. 


\section{CHAPTER VI}

MEXICAN FINANCE: FOREIGN LOANS AND FOREIGN CLAIMS

In discussing the financial operations of a well ordered country the layman's order of approach may be to review the expenditures that it undertakes and their purposes, the resources from which it draws its revenues for meeting current expenses, and, finally, the debts contracted outside the course of its ordinary life and the provisions made for paying them. But in studying many of the Latin American republics the conditions seem to counsel studying the debt first and then looking to what financial resources there are from which to pay the interest and sinking fund charges and the expenses of current activities. In some cases the national debt or a portion of it dates from before national independence and has been an important factor in the national politics throughout the life of the state.

In new and undeveloped countries also the national debt takes an unusual prominence in discussions of national finance because it is regularly a foreign debt, at least in majority, and carries with it, therefore, possible complications with other powers. Often its payment will have been undertaken at a time when the national credit was so low that the capitalists were not willing to accept the state's general promise to pay but insisted 
on the assignment of some specific income, such as the revenue from a stamp tax or a percentage of the customs dues at a certain port. Such arrangements make the creditor's claim one still more intimately connected with both foreign relations and domestic politics.

Mexico's financial history-both that of her foreign and of her internal financial operations-is a tangle that cannot be reviewed here except in the most general outline. ${ }^{1}$ From the beginning to the end of the Diaz régime there was a fairly steady improvement in the international standing of the republic. Defaulting, which was formerly a steady habit, disappeared after order was established, and bonds could be sold with interest and rate of issue which did not make them usurious. This had by no means been true in early Mexican history.

In 1824, for example, when obligations of a face value equivalent to $\$ 16,000,000$ were issued for Mexico by the British house B. A. Goldsmidt \& Co., the five per cent bonds had to be floated at $58 .^{2} \quad A$ six per cent loan the following year brought 893/4 per cent. After 1827 the interest went unpaid for a time and later was paid only irregularly.

Between 1837 and 1839 the debt and unpaid interest were refunded. The total of the obligations recognized

${ }^{1} \mathrm{~A}$ more detailed review of the foreign debt is found in the Forty-fifth Annual Report of the Council of the Corporation of Foreign Bondholders ... for the year 1918, London, 1919, from which the figures in the following paragraphs are largely taken. See also a careful analysis by W. F. McCaleb, The Public Finances of Mexico, New York, 1921, passim.

${ }^{2}$ The figures in this chapter are in Mexican gold except where otherwise stated. 
was now about $\$ 54,573,730$. At this time, too, the debtors took an added security for the risk they assumed in the grant of one-sixth of the customs receipts of Vera Cruz and Tampico, the two important east coast ports, for the service of the debt. But arrears arose again and in 1842, in return for raising the share of the customs receipts devoted to the loan from one-sixth to one-fifth, the creditors accepted non-interest bearing "debentures" at the rate of one dollar for each two dollars actually due.

In 1846 the creditors agreed to another cutting down of their claims. Various classes of bonds were rescaled at 90 to 60 per cent of their face, the outstanding foreign liability of $\$ 56,206,875$ being decreased to $\$ 40,533,-$ 425. A new five per cent loan was issued to cover this and certain other liabilities. This time the security included besides one-fifth of the collections of the two ports, a fifth of the tobacco duty and the export duty on silver shipped from the west coast.

The agreement had hardly been made when war came with the United States and as a result the ports of the east coast fell into possession of the enemy, thus cutting off part of the guaranteed income. A similar agreement was put into force again in 1851. Interest payments fell into arrears. A new refunding issue was put through in 1864 but payments almost immediately fell behind again.

In 1864 the government of Maximilian floated a loan in London and Paris of $\$ 61,825,000$ at 63 to secure funds to crush the republican forces. These obligations were later partly converted into a second loan. When 
the empire fell the republic definitely repudiated both sets of debts. A part of these issues was later repaid to the bondholders by France.

Further borrowings abroad were not resorted to until 1886. The new régime then and in $\mathbf{1 8 8 8}$ put through refunding measures. In 1889, it sponsored the Tehuantepec Railway Loan, paying five per cent, issued at $\mathbf{7 7}$ to the amount of $\$ 13,500,000$. In 1890 , an issue of $\$ 6,700,000$ of six per cents was made at 65 to secure money for the Monterey and Mexican Gulf Railway. In 1890 , an external six per cent loan was made of $\$ 30$,000,000 face, issued at $931 / 2$ per cent secured by 12 per cent of the total proceeds of the import and export duties. Three years later another 12 per cent was pledged for the service of a loan of $\$ 15,000,000$ bearing six per cent and issued at 68 .

Just at the end of the century the five per cent External Consolidated Gold Loan was put through which is the oldest of the direct external loans now outstanding against Mexico. For its service there was to be set aside 62 per cent of the national import and export duties. The face total of the obligations was $\$ 113,-$ 500,000 .

Mexico was now reaping the fruits of the establishment of order. Foreign capital was flowing across her borders from all directions seeking opportunity to develop her resources. Her international credit stood on a better basis than ever before. In 1903, the City of Mexico was able to sell at 85 , bonds amounting to $\$ 12$,000,000 , bearing five per cent interest. The next year the central government floated at 94 a loan of $\$ 40,000$,- 


\section{MEXICO AND ITS RECONSTRUCTION}

000 bearing only four per cent and that without setting aside any specific portion of the national revenues for its service.

These were days in which Mexico did indeed seem to be coming into its own. It took up its older obligations bearing higher rates of interest, it paid off by the new loan amounts it had borrowed at six per cent to encourage building of railroads, and started public works under government support at its less favored ports on both coasts.

In 1910, another refunding operation took place. The loan of 1899 paying five per cent was changed to one bearing four per cent. The half of the new loan issued in Paris in July sold for $\mathbf{9 7 . 6 2 5}$ per cent. It was guaranteed by the 62 per cent of the import and export duties, which had protected the loan of 1899.

The cloud of revolution was already gathering but the world would not believe that its threat was serious. Progress in Mexico had been so steady for a generation that it was pointed to as the greatest of Latin American states. A country, which in 1890 saw its six per cent bonds sell at 65 per cent, now sold its four per cents at less than three points below par.

Its government, it seemed, was at last truly in a position to give protection to life and property. It could now look forward to an intensive development of its national resources sure to be as wonderful in its results as their extensive exploitation of the last quarter century had been. The government could undertake public works without having to pay high rates of interest and, most needed of all, the friends of Mexico felt that 
now had come the time when the government, at last securely on its feet, should and could give greater attention to improving the social and economic well being of its people.

All told the direct external loans, those of 1899, 1904, and 1910, now amounted to $\$ 140,709,065$ plus the other issues guaranteed by the government. These latter totaled $\$ 104,071,950$. The two classes together made a debt of $\$ 244,781,015$; or, if the $\$ 50,747,925$ General Mortgage Four Per Cent Gold Bonds of the National Railways of Mexico be included, $\$ 295,528,940$. This was a debt easily borne by a nation of $15,000,000$ people whose territory was developing as had that of Mexico in the last quarter century.

But the financial history of Mexico since 1910 does not justify the confidence which the investing world then placed in her nor the hopes that her friends then held. The revolution was not a passing and unimportant storm. It soon became evident that it was a much more fundamental demonstration than even the Mexicans best informed appear to have believed at the beginning. One of the indirect results that have followed in its train has been the temporary paralysis of Mexican foreign credit. When it was realized that the revolution was a serious movement, borrowing at once became difficult.

In May, 1913, a six per cent loan amounting to $\$ 80$,000,000 was authorized by Presidential decree. It is certain that $\$ 8,100,000$ worth of these credits were issued and it is understood that a very large proportion of the balance has been used for various purposes. No 
further loans appear to have been made abroad. ${ }^{3}$ To the difficulties of raising a loan brought about by the revolution there were added those caused by the World War-none of the lending nations of Europe had money to lend after August, 1914; and through much of the period since that date neither the government nor the people of the United States would have been willing to loan important amounts in Mexico.

But the World War is not the cause of the failure to keep up the services of the foreign debts of Mexico. All but one of the Mexican external debts, direct and indirect, were in default after July 1, 1914, a month before the outbreak of the war in Europe and since January 1, 1915, no payments whatsoever have been made. Meanwhile the obligations grow. By January 1, 1919, they had come to total $\$ 336,344,080$, not including the bonds of the National Railways of Mexico.

When the foreign debt service will be resumed, of course, no one can tell. On September 1, 1918, President Carranza in his message to Congress stated that Congress had authorized him to contract abroad or in the republic three loans amounting to $\$ 300,000,000$. But these were not apparently for the service of the foreign obligations already incurred. The government issued an official statement in January, 1919, to the effect that it intended to resume the payment of interest and settle arrears of interest on the foreign debt "as soon as the external commercial life of the Nation has been regulated." Claims have been put forward since

3 The various issues of the revolutionary period not taken up above are discussed in W. F. McCaleb, op. cit., passim. 
that time that those now at the head of the affairs of the republic control practically the entire national area and that its foreign trade has been unusually prosperous. Nevertheless the recovery of normal conditions and the resumption of the services of the foreign debts seems to outsiders still in the indefinite future.

Unfortunately, when the revolution is over, the international obligations of Mexico will not be measured by the loans the government had made previous to the outbreak of the civil war and the accumulations of unpaid interest. In every civil war there arise large numbers of claims by individuals for damages, which the government is called upon to settle. These, so far as the citizens of the country are involved, can be disregarded if the government so decides, but the damages suffered by foreigners are not so easily put aside.

The destruction wrought by the armies of various leadership that for the past decade have been keeping Mexican public life in a turmoil, and the destruction due to the actions of the governments themselves, especially in interfering with the operation of railroads and banks, the property of foreign interests, will be the basis of a host of claims that will probably amount to at least as much as the outstanding public debt. When peace comes to Mexico, the national obligations to others than its own citizens will thus have grown out of all proportion to those carried before the Civil War. It is not possible at this time to give a satisfactory estimate of the claims that will be presented for payment. A large number, and probably the most important, will be those of companies, especially those which were engaged in 


\section{MEXICO AND ITS RECONSTRUCTION}

services affected with a public interest such as the railways, tramways, and light and power companies. On July 31, 1919, the Department of State of the United States reported that 942 claims had been filed by American citizens. Of these $\mathbf{7 8 9}$ made a statement of the extent of damages suffered totaling $\$ 26,629,397.61$. The claims of the largest companies operating in Mexico appear not to be included. No information is available showing the extent of damages of citizens of other nationalities. On November 24, 1917, President Carranza by decree established a commission for the consideration of all claims by foreigners against the government, but the procedure provided was of such character that the United States did not find it possible to approve it."

It is not possible at this time to state the amount of the debt of Mexico which involves the rights of foreigners. The current discussions are seldom detailed. Thomas R. Lill, an American accountant, in the service of the Carranza government, stated before the Senate Committee on Foreign Relations, on September 23, 1919, that the total debt left by the Diaz régime was about \$425,000,000 Mexican gold. He declared the bonds approved by the Madero Congress and issued by Huerta amounted to another $190,000,000$ pesos; loans due to banks, 53,000,000 pesos; and back salaries due to employees to $25,000,000$ pesos. This would make a total of $693,000,000$ pesos, ${ }^{5}$ not including about 170,-

${ }^{4}$ Senate Document 1, 66th Congress, 1st Session, May 20, 1919, and Senate Document 67, 66th Congress, 1st Session, August 1, 1919.

${ }^{6} \mathrm{C}$. Adolfo de la Huerta in his Presidential address reported in 
000,000 pesos interest due. Luis Cabrera, Secretary of the Treasury in President Carranza's Cabinet, reported the total national debt as about $1,000,000,000$ pesos, or $\$ 500,000,000$ United States gold. This estimate did not include a number of important items said to be claimed by several foreign governments. ${ }^{\circ}$ The secretary of Hacienda announced that the total debt as of December 31, 1920, including foreign, internal, and state delegations, amounted to $\$ 426,791,555$ Mexican. Accrued interest and Tehuantepec Railroad bonds amounted to $\$ 197,707,142$ Mexican. The total of these items is $\$ 624,498,697$ Mexican.

These estimates by employees of the Carranza and Obregón governments are much smaller than those of some of the best informed Mexicans outside governmental circles. A calculation published under the direction of a group of Mexican economists places the interior and exterior debt in August, 1920, at $\$ 1,200,000,000 \mathrm{Mex}-$ ican. The obligations that the country has incurred through damages to banking, railway, and other interests belonging to nationals and foreigners is referred to as an additional large but unnamed sum. The cash

the Diario Oficial, September 2 et seq, 1920, reported the entire obligations, foreign and domestic, as totaling 657,599,122 pesos, including interest due.

- These statements are based on the summary in the Commercial and Financial Chronicle, November 15, 1919, p. 1837. The testimony as to the amount of the Mexican debts is presented in detail in Investigation of Mexican Affairs, Hearing Before a Sub-committee of the Committee on Foreign Relations of the United States Senate, 66th Congress, 1st Session, pursuant to S. Res. 106, part 3, Washington, 1919.

'Commerce Reports, June 14, 1921. 
taken over from the banks manu militari amounted to about $\$ 54,000,000$ Mexican "according to the official figures of the Carranza government." 8

Before leaving the discussion of the foreign debts of Mexico it is worth while calling attention to several features of their history which may have a bearing on what may be expected or what should be demanded by investors in the period of reconstruction.

First of all, it is often asserted by Mexicans and by mistaken friends of Mexico that the republic has always meticulously fulfilled its financial obligations. The facts concerning the foreign debts above outlined make it necessary to interpret these words in a very special way if they are to be held to state the truth. As has been indicated, the earlier history of Mexico shows important readjustments of the claims of foreign creditors which cut down the amount they were to be paid. To be sure the creditors agreed to the scaling of their claims and it may be insisted that Mexico did not repudiate the obligations, except in the justified cases of the Maximilian era. Nevertheless, it is true, of course, that the reduction of claims was not a free-will offering upon the part of the creditors. They consented because the finances of the republic had come to such a state that they felt it desirable to sacrifice part of their property in order to obtain a chance to save the rest. Mexico may not have repudiated her obligations actually but

${ }^{8}$ Manuel Calero, Ensayo sobre la reconstrucción de Mexico, New York, 1920, p. 89. This review published by a group of nine prominent Mexicans headed by Manuel Calero is a good summary of moderate progressive opinion on Mexican affairs. 
the effect upon the creditors was the same as if they had held the notes of a corporation that had become bankrupt and could not pay its creditors in full. It need hardly be said that this is not a way of fulfilling its financial obligations that contributed to the credit of the republic.

The claim so often made in connection with Latin American countries that their revolutions are not to be taken seriously and that they have no important effect on the national economic life, has no application when the foreign loans of Mexico are under consideration. When Mexico has not had a stable government, she has not paid regularly interest on her debts and the principals of the debts have been paid by new borrowings. The only long period in which interest payments were punctually made was in the Diaz régime.

Unless some guarantee of payment of interest and principal can be secured that will be enforceable and that will be enforced by some other government if Mexico fails to do so, the loan of money to any Mexican government that has not proved its stability is a highly speculative venture. The interest rate that the investor will have to demand will naturally be higher, that is Mexico will have to pay more, if there is no guarantee. These are facts, which those who refinance Mexico in the reconstruction period will have to take into serious consideration. It may well be doubted whether the dangers to national independence alleged to attend foreign loans are less when money is borrowed in the open market at a high rate by a weak nation, than when made at a lower rate under the guarantee of a more power- 


\section{8}

\section{MEXICO AND ITS RECONSTRUCTION}

ful country that it will help so to shape conditions that the stipulations of the contract may be fulfilled.

Thirdly, the declarations on the part of certain Mexican statesmen that any sort of special guarantee for the payment of debts is without precedent, a reflection on the national honor and not to be considered, are declarations that lack straightforwardness. The financial record of the republic shows numerous cases of hypothecation of special revenues for the service of the foreign loans. In fact the republic, except for the first quarter century of its existence, the record shows, has never been without special claims on the national income in favor of certain of its foreign creditors.

The direct external loans now in force are all, with the exception of the gold loan of 1904, nominally under the protection of special guarantees. The loans of $\mathbf{1 8 9 9}$ and 1910 are secured on 62 per cent of the national import and export duties and the bonds of 1913 issued dur ing the revolution are a lien upon the rest.

Governments avoid such agreements if they can, but Mexico has not been able to do so. She seemed to be approaching that condition in 1904 and doubtless the loan of 1910 might have been negotiated without special guarantee but for the fact that it was a refunding measure and the creditors were in a position to demand the continuance of their former security. It seems hardly to be expected that any project for financing the reconstruction of the country will lack features of this sort.

What guarantees of this sort actually mean is not clear. In times of peace, with a responsible government 
in control, they constitute a check on the spending power of the government and promote promptness of payments. But under normal conditions a responsible government pays even without such guarantees. In time of civil disturbance in Mexico none of the passing governments has apparently felt the agreements to be ones it must obey. At the only time when reliance needed to be placed on the special guarantees they did not serve, and the bondholders find themselves in a position in which it appears the local government does not recognize its responsibility nor can they force it to do so by calling on their home governments to aid in securing the fulfillment of the contracts.

It is true, of course, that the Mexican debt service clauses may at any time be held to mean more than has appeared to be the case. The debts went into default just before the outbreak of the World War, and had peace continued elsewhere during the later period of the revolution it is possible that pressure would have been put upon the government of Mexico to live up to its contracts.

If this is not the case, it appears clear that the form of guarantee found in Mexican loan contracts is of little value whenever a government wishes to disregard it, whether in time of peace or of civil disturbance. If a guarantee cannot be secured, which means that the foreign government shall have a right to see to its enforcement, and if the enforcement by the foreign government cannot be considered reasonably certain, then investors in the securities of unstable countries must consider their money risked in a speculative venture for which they 


\section{MEXICO AND ITS RECONSTRUCTION}

must be compensated by high interest rates or low rates of issue or both.

That such a basis for the financial rehabilitation of Mexico would be unfortunate is clear. If the debt service guarantees furnish a basis upon which other countries may help her to help herself, she may secure domestic order and a responsible government sooner than would otherwise be her lot. If those debt service contracts now in existence do not furnish such a basis and the Mexican government refuses to enter new ones that will do so in the future, then it must borrow on the chance which it has, unaided, of being able to meet the obligations it assumes. It will perforce load the people with greater obligations than would be necessary otherwise and delay the real reconstruction, which every friend of Mexico must hope may soon begin and rapidly progress. Some sort of effective international guarantee of the foreign loans seems highly desirable, not only for the protection of the investor and not even principally for him, but for the benefit of Mexico and of her people.

The basis on which debts should be paid in justice to the lender often bears a strong contrast to that which is practical. What has occurred in a number of instances in the past may again prove to be the case in Mexico. At first sight even the highest figures discussed do not appear to be an overwhelming load for the nation to bear. Compared to the burden that the World War has put upon many Western nations, the debt seems small. Even assuming that the total may be as great as $\$ 1,500,000,000$ Mexican, the debt per 
capita would be only about one-fourth as great as that which the people of the United States are now called upon to carry. But such comparisons are deceptive for they fail to take into account the economic weakness of the Mexican population even in comparatively prosperous times, a weakness now much accentuated by a decade of civil disturbance.

Mexico, in the old régime, mortgaged her future to secure economic advance. She now finds herself called upon to mortgage the future to pay the cost of the upheaval that destroyed much of the advance attained. Unfortunately the pressure to meet her obligations comes upon her at a time when she is least able to make favorable terms. The post-revolutionary governments face a world money market in which the French government has to borrow abroad at eight per cent and in which that interest rate is a fair average of the payments on the loans of the most favored of European countries. It is hardly to be expected that under such circumstances those who loan their money in Mexico will not expect an unusual return.

When the Mexican governments look to the resources upon which they can count to meet the interest on their borrowings, past and to come, the prospect is far from encouraging. In a country even now not completely at peace with itself money must be raised from agricultural interests badly disorganized, cattle resources hard hit by the drain of ten years' army requirements, mining still suffering from the results of disturbed industrial conditions, and a labor supply depleted of many of its most enterprising elements by emigration. What com- 


\section{MEXICO AND ITS RECONSTRUCTION}

merce can be taxed must move over roads and railways very badly neglected and must rely on banking facilities still sadly inadequate. To this discouraging outlook is to be added the declining price scale of the chief commodities that Mexico sends to foreign markets.

Confronted by such an economic outlook it is not to be wondered at if the Mexican governments fall into believing that the end justifies the means and like a drowning man catch at straws. 


\section{CHAPTER VII}

MEXICAN FINANCE: CURRENCY AND THE BANKS

As has been indicated, the debts of Mexico to its own citizens are not ones that involve the possibility of international complications. If Mexican property is destroyed, the only recourse for the injured is to the Mexican government. To what degree the governments of the reconstruction period will feel themselves bound, or find themselves able, to make restitution to Mexican citizens for property confiscated, or taken over in return for warrants issued by the various generals, can not be indicated. There is little reason to believe that any serious effort will be made for a general restitution. Much of the property was taken or destroyed under such confusing conditions that it would be impossible to determine what justice demands. In addition, the government will not pay because it cannot if it would. Heavy as the foreign obligations of Mexico are, the domestic ones are on their face still greater.

Much of the property loss suffered by the Mexican people occurred in connection with the various issues of paper money authorized by the passing governments and put in circulation under circumstances that made them practically the equivalent of forced loans. In fact far the greater part of the nominal value represented by them already has been finally repudiated and whatever loss occurred will never be repaid. 
All but a small part of this money, it is true, never circulated at its face value, if indeed any of it ever did, a fact that has disposed those who have come into power to refuse to redeem it at its face. It is beyond doubt, however, that the rates at which the issues that have been "redeemed," were paid for, were lower than those at which they were originally issued and that this loss has fallen on the people of Mexico.

The extravagant character of the paper money régime through which Mexico passed and from which she has recently made successful efforts to free herself can be judged best in the light of the currency system, which had been created previously.

Through a large part of Mexican history the coinage has been intimately connected with the taxing system. Precious metals were so important a part of the exports of the country that the expedient of taxing them was early resorted to. The system that came into use was to require all gold and silver extracted to be taken to the mints where it was made into coin at a charge of about five per cent. In addition, an export duty of five per cent on silver and one half per cent on gold was levied on the metal leaving the country. In 1872 export of silver in bars was allowed, providing it went through the mints and paid taxes almost as heavy as if coined. On November 1, 1882, all export duties on metals were removed. Under these conditions currency in Mexico approached more nearly to the character of merchandise than in most countries.

The Mexican eagle dollar coined in the early years of the Diaz régime weighed .869 of an ounce and was of 
.901 fineness. It sold abroad by weight usually at a slight discount as compared to bar silver though occasionally it had a premium for export to the Far East where it circulated as coin. ${ }^{1}$

By Presidential decree of March 25, 1905, and the monetary law of December 9, 1914, the Mexican monetary unit was declared to be the silver peso the value of which was fixed by the law at the equivalent of $\$ .4985$ in United States gold coin. This legislation placed Mexico among the countries using the gold standard.

Those in control of the government in the first years of the revolution avoided the use of paper money but a more radical policy was adopted to furnish funds to finance the revolution headed by Carranza. On April 26,1913 , to help pay the expenses of his army Carranza, by decree, authorized the issue of $\$ 5,000,000$ Mexican in paper since known as the Monclova issue. These bills were to pass at face as legal tender. Those who refused to accept them faced jail sentences.

As often has been the case when governmental authorities have yielded to the temptation to issue fiat money, it became in this case impossible for them to summon the resolution not to do so again. It was an easy way to meet expenses. The bills issued were poorly printed and counterfeits soon appeared from all directions, including United States ports. Even the official issue

${ }^{1}$ Reports from Her Majesty's Diplomatic and Consular Officers Abroad, Commercial No. 36 (1883), ... Part VII, .. Report by Lionel E. G. Carden on the trade and commerce of Mexico, gives a good description of the conditions in the early eighties of the last century. 


\section{MEXICO AND ITS RECONSTRUCTION}

was soon exhausted. Another decree of November 28, 1913, raised the total by $\$ 20,000,000$ Mexican and was soon followed by others necessitated by the continuing needs of the army and the steady decline in the rate at which the bills were currently accepted. Meanwhile Villa, Zapata, and others were issuing rival currencies forced into circulation in the districts they controlled. Later Carranza was forced to retire to Vera Cruz and from that city he issued quantities of "Vera Cruz bills." The value of Carranza paper continued to fall, and counterfeits continued. It was evident that soon the "bilimbiques," as his paper was nicknamed, would be so low in value that they would not circulate at all.

Under these circumstances a decree was issued July 21, 1919, alleging that counterfeits had destroyed the confidence of the people in the paper issued and authorizing another issue of "infalsificable" notes, which were to retire all Carranza paper previously authorized. The issue was of $\$ 500,000,000$ Mexican and was to be backed by metallic reserves which never were created. These bills were printed in New York and, unlike their predecessors, were well made. Previous issues of the Carranza government, not counterfeits, were to be redeemed at a set rate until June 30,1916 . All paper currencies, except the new issue, were then declared no longer legal tender.

All told there had been some 200 issues of various origins current in the republic, most of which had rapidly declined in value after their appearance-as the "infalsificables" now proceeded to do.

The total paper currency "legal" and "counterfeit" 
put out in 1913-16 is estimated to have had a face value of over $\$ 2,000,000,000$ Mexican. The Carranza issues alone totaled about $\$ 1,250,000,000$ as follows: ${ }^{2}$

Monclava .......................\$ 5,000,000 Ejercito Constitucionalista ............. 25,000,000 Gobierno Provisional (Mexico City)........ 42,625,000 Vera Cruz (Provisional Government)....... 599,329,321 Infalsificable . . . . . . . . . . . . . . . 599,329,321

The record of the effects of the paper money issues upon the economic life of the nation reads like pages from the Arabian Nights. As long as the money, issued in large quantities, had any appreciable value, those who could command gold and who were in a position to profit by a rapidly falling exchange were able to build up fortunes in a way little short of fantastic.

Wages remained nominally at their former standard for a time and then adjusted themselves but slowly to the new money values. Large debts could be paid off with money the current value of which in gold was as low as five per cent of its face. When the government took over the banks, it found itself caught between its own decree that its paper must be accepted for payment of all obligations and the fact that the loans and mortgages of which it had taken charge could be paid off in the same money.

Real estate purchases from sympathizers with the old régime or persons despairing of the reëstablishment of

2 These figures and the facts cited above concerning paper money issues are taken from W. F. McCaleb, The Public Finances of. Mexico, New York, 1921, pp. 223-39. 
order were made on the most remarkable of terms. The property might be heavily mortgaged to a neighboring bank, but the owner might at the same time have an equity representing a considerable capital. Nevertheless, in the face of the revolutionary storm, his first impulse was to save what he could and make his way out of the country to safety. He would sell his property at its former value accepting payment in depreciated paper at its face, pay off his mortgage to the bank in the same paper, and leave the country.

The result of such operations was peculiar, the adventurous buyer got the property for perhaps a twentieth of its real gold value, yet he paid a fair price in the money that the government was forcing the people to accept. The seller was equally well satisfied for he paid off his debt to the mortgagee under terms that the government itself upheld and he saved at least a little from ruin. The government, which had brought on these conditions and which through taking over the banks was under obligation to receive its own depreciated currency as the measure of the non-metallic assets, into possession of which it came by that act, was the only party to the transactions which might be disappointed. In the background, for the moment at least, were the former stockholders of the banks who saw their assets vanishing with only a hope that they might be reimbursed for their loss at some distant time.

The period of wildest financial inflation fell between October, 1914, and October, 1916. On the whole the course of all the paper issues was steadily downward. By the latter part of 1915 Vera Cruz bills, for example, 
were worth about one per cent of their face. When the "infalsificable" came out in April, 1916, it was accepted at a gold value of about 20 cents Mexican. The government forced its acceptance by decree. For a time the old Vera Cruz issue was exchanged against the new money at ten of the old for one of the new. Then even this sort of "redemption" ceased. The "infalsificables" began to depreciate alarmingly. Eight months after their issue they had fallen to 80 to one as compared to gold and at the end of 1916 they were little better than Vera Cruz bills.

Their subsequent history is brief. They were never formally repudiated by the Carranza government. When it had been decided that the "infalsificables" could no longer be relied upon as the regular currency, it was arranged to demand that all customs dues be paid in gold plus an equal amount in "infalsificables." In this way the issue was to be "redeemed." At first the requirement was little more than formal, for the bills were practically valueless. By July 10, 1919, $\$ 397,119,298$ Mexican were reported to have been retired and by October 18, 1919, their value had risen to $\$ .0765$ in Mexican metallic currency. ${ }^{3}$ A summary of the gold debt issued by Minister Cabrera published in 1920 assigns an item of $\$ 10,125,000$ Mexican for the redemption of Vera Cruz and "infalsificable" bills."

${ }^{3}$ Commerce Reports, November 26, 1919.

- El Heraldo de Mexico, March 26, 1920, quoted by W. F. McCaleb, op. cit., p. 252. The Presidential address of C. Adolfo de la Huerta published in the Diario Oficial, September 2, 1920, states that the "infalsificables" then outstanding totaled $\$ 106,787,862$ Mexican. 
The Carranza government had meanwhile decided that the time for reliance on paper currency had passed and a decree issued that all payments should thereafter be made in coin.

This third attempt at regulating the currency system was inaugurated in December, 1916. It had a success far beyond what might have been expected and certainly far beyond that which would have attended it had not conditions outside the republic become abnormal and such as to help the Carranza government in its new experiment. The World War was now in its most critical period. Prices were high and there was an unprecedented export demand for all articles that the muchtried country was able to produce. These conditions brought to Mexico the unusual circumstance of a favorable balance of trade. During previous years a large part of the gold coinage had been exported, and with the coming of the paper money era silver disappeared or fled the country. Even the smaller metallic coins tended to be withdrawn at one time and had to be replaced by little slips of stamped cardboard.

Now, however, with the favorable balance of trade, gold was flowing back into the country, silver was rising in price and silver continued, as it had always been, one of the things produced in large quantities. Between December, 1916, and July, 1918, the coinage of money within the country reached the unprecedented total of $\$ 93,900,000$, from which coinage, it may be remarked in passing, the government had profited through the stamp tax, assay charges, and other levies to the amount of $\$ 6,000,000$. This coinage was not only silver. Gold 


\section{CURRENCY AND THE BANKS}

produced in the country which the government could coin, it would not allow to be exported. It had to be sent to the mint. Gold bearing ore could be exported only if an equivalent value in gold was returned to Mexico. Silver could be exported only if an equivalent of 25 per cent was returned in gold. Evidently events had turned in such a way that the creation of a metallic basis for the currency could be accomplished much more easily and quickly than would have been the case in normal times. By June, 1918, there were reported to be $\mathbf{2 5 0 , 0 0 0 , 0 0 0}$ silver pesos in circulation in the republic.

The next development was the monetary decree of November 13, 1918, induced by the continued rise in the value of silver. The old pesos were withdrawn and a new series issued about three-fourths the size of the old ones, weighing $181 / 2$ grams of which $141 / 2$ were pure silver. New subsidiary coins were also issued. The gold basis for the currency was not disturbed. In the process of the change from one basis to the other large amounts of the coins of the old issue were melted down and sold as silver by those who had hoarded them. The transfer from the old to the new currency does not seem to have involved serious difficulties to local commerce.

A review of the financial problems that confront the republic must include at least a brief mention of the more recent banking developments. ${ }^{5}$ Before the revolution the banking system of Mexico was based on the law of 1897, which divided financial institutions into

${ }^{5} \mathrm{~A}$ detailed discussion of Mexican banking is found in W. F. McCaleb, Present and Past Banking in Mexico, New York, 1921, passim. 
three classes: (1) banks of issue; (2) mortgage banks, which made loans on urban and rural properties and issued bonds secured by a similar guarantee; and (3) banks of promotion to encourage mining, agriculture, and industry. Under this law there were established, between 1897 and 1913, 32 banks of issue of which 20 were in existence in the latter year with assets amounting to $\$ 425,500,000$. Mortgage banks also flourished. Four had been established by 1913 with assets then totaling $\$ 43,762,000$. Banks of promotion had been created to the number of six which in 1913 had assets of $\$ 83,000,000$.

In addition to these institutions, operating under the law of 1897, there were a loan bank for promoting agricultural and irrigation enterprises, six branches of foreign banks, a number of private banks, and a national pawn shop, which had some of the characteristics of a bank.

During the revolution this financial structure was torn down. The assets of $\$ 600,000,000$ were wiped out, its reserves taken over, and the institutions finally declared insolvent. Since 1914 the country has been practically without banks as that term was used in the law of 1897 . By an order of September 15, 1916, the government closed all the regular banks. A few private institutions have since been in operation but their activities have been confined practically to purchase of foreign exchange and minor commercial credit transactions.

What is to take the place of the former Mexican banking system is not yet clear. The Congress granted to the President power to establish a single bank of 
issue by decree. In September, 1918, he reported a bill to Congress and stated that he had not acted on the authority before because of the uncertainty of the money: market. The measure proposed provided for a single bank of issue similar in name to those under the law of 1897 but with more restricted powers. There were also petroleum banks, for the encouragement of the oil industry and banks of deposit. Branches of foreign banks were to be required to come under the law within six months or cease operations. The foreign banks, their capital and their employees were to be considered Mexican for all purposes. Appeal to the home country could not be taken on their behalf. The program was one that reflected the general policy of "nationali-

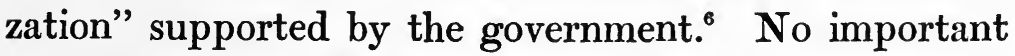
advance in banking legislation has as yet been made by. the revolutionary governments.

- A review of Mexican banking from which the above facts are chiefly taken and which gives a detailed analysis of the proposed law is found in Commerce Reports, February 1, 1919, "The New Banking Law of the Republic of Mexico," by Edward F. Feely. See also on currency issues and banking Investigation of Mexican Affairs, Hearing Before a Sub-committee of the Committee on Foreign Relations, United States Senate, 66th Congress, 1st Session, pursuant to S. Res. 106, Washington, 1919, part 5. 


\section{CHAPTER VIII}

\section{MEXICAN FINANCE: PUBLIC INCOME AND EXPENDITURE}

As in every other country the means at the disposal of the Mexican government for meeting its foreign and domestic obligations are determined by the natural resources of the country, the economic development of its people, and the taxation system that has been adopted. 'The latter two elements are capable of gradual changes. Such have occurred and are in process. But neither can be revolutionized with the overthrow of one government and the establishment of another, because each depends upon the development of the factors that precede iteconomic development of the people upon the development of the natural resources and taxing practice upon both.

The collection of public revenue in Mexico during the colonial period was not according to any well thoughtout plan as to where the burden should lie. There was no taxing system properly so called, but the government merely laid its hands on the sources of revenue from which returns could be secured most easily. Tax collection was haphazard; it affected persons, articles, and places that could be easily reached. Opportunism and not a fair distribution of burden was its guide, and many of the levies were thoroughly uneconomic and 
checked progress even in the lines Spain wished to encourage.

Since foreign commerce did not grow and could not yield heavily, internal commerce was forced to make payments at internal customs houses, which beyond doubt kept back Mexican economic progress.

Nevertheless it is easy to criticize, but hard to see what other method could have been pursued by Spain. Her hold over the country was after all so far from that which under modern conditions is possible, the transportation system was so poor, and the persons upon whom she could rely for honest appraisements and collections so few, and at best so unfitted to deal with the problems that faced the colony, that while all can see that the taxing methods used were unfortunate, it is harder to state what could have been better adopted under the then existing conditions.

There were four classes of taxes in the Spanish régime.

1. Taxes that were sent back to Spain, such as those on quicksilver and tobacco.

2. Special taxes, the tenths, the ecclesiastical subsidy, and a few others of like nature, which were destined to particular uses and not available as general income.

3. Another class was separate incomes known as ajenos. Such were the Pious Funds of the Californias, the taxes on pawn shops, income from prohibited liquors, and certain levies on mining. These were not resources that were covered into the treasury. Some of them were collected, however, by the administrative officers and spent by the government directly. 


\section{MEXICO AND ITS RECONSTRUCTION}

4. Finally there were the levies classed as common taxation. They did not differ in nature from the foregoing but they were the source of the public treasury income from which the general colonial expenses must be paid. These taxes themselves fall into classes, those on the production of metals, especially silver and gold, formed an important part of the total. There were taxes on other products, the entry or production of which could be easily controlled such as salt and silk, powder and pulque. Stamp taxes on business documents and many others, paper taxes, anchorage dues, and taxes on commerce for maintaining or building certain fortifications were included in the list. Lotteries were taxed, and there were some unimportant returns from levies on land. Highly important were the alcabalas, the taxes on internal commerce.

When the country won its independence from Spain, the public treasury was empty and private property burdened by the destruction that had occurred during the struggle. Some of the taxes mentioned, especially those in the first classes, were abolished but there was no general reform. The problem continued to be how to get income to run the government, rather than the ideal way in which to get it. Many of the old taxes were continued, although they had long been a source of complaint. Before any comprehensive reform could be put into operation the Mexicans had begun the long series of internecine conflicts that kept them too busy to consider tax laws except as a means of satisfying the immediate needs of the government. In fact, it is not possible to ascertain either the amounts collected or all 
the tax laws that were nominally in force in the period following the winning of independence.

The tobacco tax under the republic went into the national treasury. Stamp taxes were continued, alcabalas remained one of the most important-in some years far the most important-source of revenue. Bullion and pulque taxes were kept up. In general, the old Spanish system was continued, as was to be expected. ${ }^{1}$

A review of the measures adopted to increase the public revenue in the next half century of Mexican history reveals no policy. There were numerous tariffs, some of which declared for developing local industry. Some progress was made in doing so in a few lines. There were scattered efforts to reduce, and later to abolish, the alcabala taxes but revolutions overturned all efforts for financial reform and made revenue of the highest importance at the same time that they made it harder to secure. This, of course, was at the bottom of the repeated default on foreign loan interest payments, already noted, and the reason why independence seemed to outsiders so fruitless of economic and cultural advance.

In fact, the struggle for a sufficient income to pay the foreign debt service and leave a working balance

${ }^{1} A$ discussion of the tax system under Spain and in the early years of independence is found in Memoria de hacienda y crédito público . . . 1 de Julio de 1910 a 30 de Junio de 1911, Mexico, 1912, p. 210 et seq. See also W. F. McCaleb, The Public Finances of Mexico, New York, 1921, the most detailed review of this field in English. 


\section{MEXICO AND ITS RECONSTRUCTION}

for the development of the country extended well into the Diaz régime. When at last order was established, the group in charge of the government gradually came to realize that transportation must be improved if the country was to be put in touch with the outside world and to develop a foreign trade that could assist in putting it on an economically sound basis. The policy of encouraging railroad building was adopted and developmental projects of other kinds were also given public support.

To what extent such plans justify themselves depends on the rapidity with which the country adjusts itself to new conditions. It was far-seeing statesmanship to put off the day when a balanced budget could be secured if a rapid expansion of national economic power could be obtained thereby, but for no nation is it possible indefinitely to cover annual deficits by loans, especially when the interest on such loans is high as is regularly the case in undeveloped regions. Mexico wisely decided to take the risk of increasing for the time being the national obligations in order to increase the national wealth and through it the financial ability of the government.

By the early '90s, when a period of financial stress was affecting the whole continent, the railway mileage had been greatly increased. Subventions had pushed up the obligations of the government and those in power had to consider whether it was not time to wait before contracting further debts until the country should have responded more fully to the stimulus of its new transportation facilities and the resulting contact with the 
outside world. The foreign commerce and the federal income had almost trebled in the 12 years preceding July, 1892, but recurring deficits made conservatism in public expenditure wise. "It is, therefore, indispensable" "to summon the determination to make our budgets balance" declared the treasury officials, "making, on the one hand, all the economies compatible with the necessity of preserving the public and on the other increasing the taxes as far as the crisis through which the nation is passing will permit." "The wise and farseeing public policy indicates the necessity of holding in the granting of subventions ... and waiting for some time until the horizon clears." 2

But to secure the advantages made possible by the railroads one important change in taxing policy was seen to be needed even with the adoption of this more conservative program, that was the abolition of the internal customs houses at which were collected the alcabalas. Whatever apology could be made for such taxation in the colonial era it was now thoroughly indefensible. The constitution of 1857 had done away nominally with taxes of this sort but the various ministers of the treasury had not dared to put the rule into effect. In 1892 the federal treasury was still receiving $\$ 2,000,000$ from the tax, an income which in the Mexican budget of that time was apologized for because it was "of considerable size, established for several centuries, and ac-

${ }^{2}$ Memoria de hacienda y crédito público . . . 1 de Julio de 1891 to 30 de Junio de 1892, Mexico, 1892, pp. 1-15, contains a discussion of this policy. A balanced budget was secured in 1895, the first since 1822. 
cepted by the country." 3 Nevertheless the economic inadvisability of continuing the levies, which were such a serious drag on commerce, was so plain that the government undertook their prompt abolition, a move that subsequent experience fully justified.

The federal taxing system underwent but slight modification in the Diaz régime. The increase of income arose not so much from the creation of new taxes as from the increased receipts from old ones. From 1876 to $\mathbf{1 8 9 2}$ no changes were made. The sources of income were first and most important the duties on imports and exports. These always have been the greatest contributors to Mexican revenue. Next in importance were the stamp taxes levied on all sorts of business transactions, contracts, sales, receipts, leases, promissory notes, bills of exchange, and the like. These two sorts of taxes together yielded well over four-fifths of the total revenue. Import and export duties alone made up about three-fifths.

Among the minor sources of income the most important were those from such things as lotteries, telegraphs, mines, and the post office. These were about 10 per cent of the entire collections. Direct taxes known as predial, professional, and license taxes yielded about three per cent and the octroi a similar amount. In 1892-3 a few other minor imposts were created by, law and later Congresses added a few. To the end of

${ }^{3}$ Ibid., pp. 11-15. See also M. Romero, "Wages in Mexico," published in Commercial Information Concerning the American Republics and Colonies, 1891, Bulletin No. 41, Washington, 1892. 
the Diaz régime, however, there was no general revision of the taxing system.

In 1902 steps were taken to protect the public revenue against the consequences of fluctuation in the value of silver. The rate of exchange for the foreign debt services was fixed in the years following the greatest fall in the price of silver, 1892-5, to allow gold 100 per cent premium. Silver later went down still further, the premium on gold rising to 150 per cent. The actual income of the country collected in silver shrank proportionately whenever it was necessary to make payments on a gold basis. It was decided, therefore, to reckon the import taxes not in silver, at their face, but in the equivalent of the rate in gold at a fixed exchange rate-220 per cent. The amount of any tax was then reconverted into silver pesos at the prevailing rate of exchange of the day.

The policy of the Diaz government in the management of the financial affairs of Mexico was fully justified by the result. Income finally came to exceed expenditure, and the adjustment of the tariff system removed the effect of the shifting value of silver on the total customs receipts. By the middle '90s the ordinary income showed a good margin above ordinary expenditure, a condition which continued through the rest of the

4 A review of the taxing system in the early ' 90 s is found in Luis Pombo, Mexico: 1878-1892, Mexico, 1893, p. 95 et seq.

${ }^{5}$ Put in force November 25, 1902, Memoria de hacienda y crédito público ... de 1 de Julio de 1902 a 30 de Junio de 1903, Mexico, 1907, pp. 7-8. 


\section{MEXICO AND ITS RECONSTRUCTION}

Diaz régime. The adoption of the gold standard in 1905 still further stabilized the financial system.

The public finances, however, were still far from a satisfactory condition from a social point of view. The balances were made favorable only by neglect of some of the greatest social needs of the republic. Education was still backward, sanitation, outside the big towns, was poor, and transportation facilities, in spite of the great advance over the pre-railroad period, were still inadequate. The taxes were not adjusted in such a way as to give proper impulse to national industrial development nor to stimulate the exploitation of the country's agricultural resources. A system of land taxation that would fall upon unproductive holding of large estates was still lacking. There was need of a large amount of social legislation so adjusted that the republic would become a truly modern nation throughout her national life. This was a task immensely greater than the financial rehabilitation which the government, under the dictatorship, had so successfully carried out. It was a task in which but little progress had been made and which the government, in spite of the evidence so clearly presented in the reports of many of its officials, had never resolutely faced.

Whether the old régime could have carried through the great socialization program that was needed may be doubted. The dictatorship had not shown itself capable of encouraging the broadening of privileges and

- See tabulation in Memoria de hacienda y crédito público, correspondiente al año enconómico de 1 de Julio de 1907 a 30 de Junio de 1908, Mexico, 1909, p. 5. 


\section{PUBLIC INCOME AND EXPENDITURE 108}

opportunities even within the small circle of whose who were its servants. There can be no doubt that the failure to face the great humanitarian work, which should have accompanied the economic regeneration of the country, was the greatest weakness of the old régime and the fundamental cause of its spectacular and tragic downfall. 


\section{CHAPTER IX}

\section{THE MEXICAN LABORER}

Tre Aztec civilization, which the Spaniards found in Mexico at the time of the conquest, depended primarily upon the labor of the hands of the people. Domestic animals, as in all America, were conspicuous by their absence. Agriculture was of the most primitive sort.

One of the most important changes in the economic life of the country brought by the Spanish conquest, greatly increasing the labor power of the country, was the introduction of European foodstuffs and domestic animals. European cereals and other foods were introduced in the highland regions and the horse, burro, sheep, and swine became common elements in the life of the country. Chicken raising spread rapidly, wool became important as a material for clothing. Later potato culture was extended and rice and coffee were introduced. European methods improved the yield of the mines and minted coins made exchange easier and gave a new impulse to the weak local commerce. ${ }^{1}$

In spite of the introduction of these favorable elements the life of Mexico did not change as much as

${ }^{1}$ A good description of the changes in the life of the people introduced by the Spanish conquest is found in Karl von Sapper, Wirtschaftsgeographie von Mexico, 1908. 
might have been expected. Mining drew attention away. from other developments, such as agriculture, but most of all the trade policy of the mother land kept the country in a backward condition. It shut out the foreigner who, by his example, might have stimulated the Indian to adopt a civilization in which industry played a greater part than in his own. It restricted the foreign trade that would have opened up the natural resources and that would have created greater necessity for labor and would have increased its reward. When the Spanish restrictions were, removed, the influences that formerly hindered development largely vanished, but the country did not advance. Disorder, which discouraged capital investment and robbed the workman of the fruit of his labor, retarded progress. Not until after half a century of intermittent revolutions did Mexico right itself. Under the discipline of a strong government it gradually removed the more important survivals of the antiquated Spanish commercial policy, and the republic for the first time came into real contact with the current of world economic developments.

For these reasons the Mexican laborer-as a laborer -has only recently had a chance to prove his merits and even now his possibilities cannot be definitely stated. ${ }^{2}$

The estimates of the Mexican workman given by those who have employed him in large numbers vary as greatly as the Mexican himself varies. In some railroad construction work overseers who have had wide experience with all kinds of unskilled labor declare him to be the

${ }^{2}$ See Wallace Thompson, The People of Mexico, New York, 1921, pp. 315-348. 


\section{MEXICO AND ITS RECONSTRUCTION}

best material they have ever had to deal with for doing rough work. Others think him "next after the Irish," "fully the equal of the Italian," and "as good as any immigrant labor I ever dealt with." Estimates of less favorable character are quite as numerous, and the Mexican employer appears to have quite as much to say about the shortcomings of the native laborer as does the foreigner. The fact that the estimates of his ability are not regional, that there is no ethnological nor sociological unity among the population, and that some foreign and some Mexican employers have marked success in using native labor in districts where others find it very inefficient makes it hard to arrive at any estimate of the Mexican as a laborer that is fair.

In whatever part of the country that is under discussion the laborer is, as a rule, an Indian laborer. $\mathrm{He}$ is the fulcrum of Mexican society. As one of the most thorough of Mexican students says, "Amidst the most terrible sufferings and crushed by all sorts of hardship the indigenous population is sustaining us, socially speaking: it carries on the agricultural labor throughout the Republic, works the mines, and effectuates all hard and heavy toils." "Our subordination to the indigenes is so patent that our actual existence depends exclusively on them." 3

The work that the Indian has been called upon to do thus far has been, as a rule, such as to test his physical endurance and industry but has given him little opportunity to show his abilities in skilled trades. The most

${ }^{3}$ Justus Sierra, editor, Mexico, Its Social Evolution, vol. 1, p. 30. 
important exception is found in the textile mills. There ignorance has stood in the way to prevent advance to responsible positions. In the few cases where this has not been the case the better paid places have not infrequently been reserved for foreigners by the management or, if Mexicans were put into places of responsibility, they were given lower wages than were paid to Europeans doing similar work. The success of certain of the native employees in the face of these difficulties shows that some, at least, have aptitude for the skilled trades. There is no doubt that even in the textile mills the abilities of the native population have not been fully tried out in the past.

The government has done little to furnish education which would develop the latent industrial ability of the people. "By the change of régime in the present century the indigenes have made no advance, they have only changed their tutors and tutor Congress, to tell the truth, has done less for them than the tutor Viceroy." 4

Under these conditions it is evidently unfair to judge what the Mexican laborer can do from what he has done. He has never had a chance to prove his worth and his cause has been an unpopular one even in his own country. The ruling class have consistently alleged his great possibilities and especially in late years not a few, when comparing themselves to foreigners, have developed a sort of Indian cult and have professed themselves of

${ }^{4}$ Ibid., p. 31. See also Alberto Robles Gil, Memoria de la secretaría de fomento presentada al congreso de la union, Mexico, 1913, p. 500. 


\section{MEXICO AND ITS RECONSTRUCTION}

Indian blood and declared themselves proud of their inheritance. Nevertheless, in domestic politics, the Indian has been a subject of general neglect. Mexico has recognized that her greatest problem is at bottom a race problem, but she has made only the feeblest of efforts for its solution.

The criticisms of the Indian laborer by his employers are those frequently alleged against the colored races, especially those living under tropical or semitropical conditions. The Indian laborer is alleged to be lazy, of few wants, preferring a low standard of life with little exertion, physical or mental, to hard work and the satisfaction of new desires. He is stolid, taciturn, melancholy, fatalistic, deceitful, and unambitious. $\mathrm{He}$ is declared childlike, quick to anger, devoted, and revengeful. With other peoples at a similar stage of development he shares a fondness for strong drink. "He never becomes an initiator, that is to say, an agent of civilization ... the native people is a static people." ${ }^{5}$ Unlike some of the native population of the United States he is said to be usually docile, easy to handle if his prejudices are not offended, and, as a rule, not a lover of fighting for its own sake. Custom plays a large part in his life and he yields to new influences but slowly. Though there are those whose experience seems to prove the contrary, it is the general testimony that the native lacks powers of sustained attention and industry. $\mathrm{He}$ is easily diverted from the task in hand. He shows, in short, in

5 Justus Sierra quoted in Luis Pombo, Mexico, 1876-1892, Mexico, 1893, p. 7. 
the work that he undertakes, an immaturity of character comparable to that of a child. These characteristics are emphasized in the hot regions. ${ }^{\circ}$

Other ethnic elements besides the Indian play an unimportant part in the manual labor supply of Mexico. The mestizo population, a growing proportion of the whole, has not turned to agricultural or industrial pursuits. What education it has received has turned its attention to the "polite professions" rather than the more fundamental occupations. That such is the case is one of the most unfortunate features of Mexican life. There is no economic bridge between the laboring classes and those who, from a false perspective, believe that working with their hands is beneath them. The education which the state has provided is literary, the envied careers are those in the law courts and diplomatic circles. Even those who receive training in engineering, agriculture, and like careers too frequently consider themselves qualified thereby for government positions or for the responsibilities of directors whose work is sharply cut off from actualities.

From these conditions results one of the most striking contradictions in Mexican life. The mestizos have developed as the owners of the greater number of small properties in the republic, they have monopolized many lines of small trade, they are the middlemen. They hold the great majority of public offices. But they have no unity of interest and feeling with the laboring classes.

${ }^{6}$ See on this point Alberto Robles Gil, op. cit., p. 94. The "vigorous" element in the hot zone are one-twentieth of the population In the temperate regions they, are one-tenth. 


\section{MEXICO AND ITS RECONSTRUCTION}

Mexico, it is true, has no hard and fast race line such as is found in the United States. It has a line of economic and social demarkation which is no less unfortunate. "Ever since the independence the Mexican mestizos and the creoles . . . divided into two parties, both of them distanced from the nature of things because of their ignorance of the actual world; not knowing the true needs of Mexican society" have "continued to agitate it" but have not established Mexico upon a sound economic, social, and political foundation. ${ }^{7}$

Foreigners, as an element in the labor supply and in office holding, can be disregarded. They have devoted themselves to trade, banking, and the development of the natural resources of the country, the latter almost exclusively through the use of the local labor. They represent a part of Mexican wealth disproportionate to their number and their enterprises have an important influence on the economic position of the country and its inhabitants, but they do not form an important part of the labor supply.

If the average Mexican laborer of the present day or of a generation ago is compared to the American laborer, he makes no favorable showing. For the dollar of wage received he does not yield more than the highly paid worker in the United States. The chief causes advanced in explanation of this fact are that he is poorly fed, poorly educated, less ambitious, and in large areas of Mexico less able to work because of climatic conditions. The plateaus are so high that the rarefied air

"Austin Aragón in Justus Sierra, op. cit., p. 31. 
makes sustained effort difficult and the atmosphere of the lowlands is so hot and humid that the laborer cannot endure the continuous physical labor of which men of northern lands are capable. ${ }^{8}$ Some of these are disadvantages that can be overcome. Some are inherent in the conditions under which the Mexican laborer lives.

Making all due allowances for the disadvantages under which it works, it is clear that the laboring population of Indian blood is one that reacts but slowly to new surroundings and one the abilities of which are still to be determined. The mestizo class, which is gaining in numbers as compared to the pure Indian, will sooner or later be forced to take a larger part in the labor of the community. The Mexican Indian as an Indian seems destined to disappear by absorption. Even though under the stimulus of foreign example and economic compulsion he should take on European habits of life, rapidly develop new wants, and become a greater factor in the national life, there is little chance of his surviving as an Indian. The chance would be less perhaps than if he continued his present mode of life, for his blending with the rest of the population would probably be hastened by unity of economic interest.

Mexico is now predominantly a mixed blood state and it seems probable will become more so. The Mexican laborer of the future, it appears, will be a mestizo and not an Indian, a condition that will be hastened by the absence of the social cleavage on racial lines,

${ }^{8}$ M. Romero, "Wages in Mexico," in Commercial Information Concerning the American Republics and Colonies, 1891, Bulletin No. 41, Washington, 1892. 


\section{MEXICO AND ITS RECONSTRUCTION}

which is found elsewhere. The aboriginal races, which formed so important a factor in the early history of the United States, have disappeared as an important factor in the national life by a process of elimination, those of Mexico, which have been, until now, the foundation on which the state has been built, will disappear by intermarriage.

What effect this development will have upon Mexican economic and political life it is, of course, impossible to say. Whether through faulty education or other causes, the mixed bloods, up to the present, have not shown themselves an industrially able population. In politics they have been wonderfully facile and disappointingly unstable. Whatever the changes that the revolution brings in the labor conditions of Mexico may be-whether the Indian for the time being comes to play a more or a less important part in the national life and whether or not the mestizo rises to his opportunity -it is clear that Mexican labor problems will be in the future, as they have in the past, to a large extent, race problems. They must depend for the success of their solution upon the degree to which the Indian, and for the future the mestizo, population show themselves adaptable to the demands of industry.

It is not fair, however, to assume, as is often done, that given the chance to develop wants the Indian and mestizo populations have shown no tendency to do so. In fact, the Indian has been brought into contact with the habits of civilized life so casually, if at all, that his adaptive impulses, which appear naturally slow, have heen but feebly aroused. The mestizo has taken on a 
surface culture but has missed the lesson that civilization means work and responsibility for those who do not labor with their hands as well as for those who do. He has developed new wants but they have not sunk deeply enough into his nature to make him, in fact as well as in appearance, a person of Western European civilization.

Along the railroads and at the seaports, wherever the currents of commerce have penetrated, demands for the simpler and cheaper manufactured articles have developed, and if education and economic changes, which would open greater possibilities of economic independence, were to reach the people, they would doubtless progress faster toward a European standard of wants. ${ }^{\circ} \quad$ Until those elements that a modern state considers it essential to furnish its citizens are introduced in Mexico, it will be too soon to judge what the capabilities of the local population are and the degree to which they will be able to keep their country their own -both in an economic and a political sense.

${ }^{9} \mathrm{~A}$ good description of the position of the Indian in Mexican life is found in Luis Pombo, op. cit., p. 7 et seq. 


\section{CHAPTER X}

\section{THE MEXICAN LABORER: HIS CONTRACT}

ONE of the greatest handicaps to the progress of the laboring classes especially among the less advanced populations is the "lack of wants." In highly developed industrial communities a sudden increase of income for the laborer does not result immediately in a wise expenditure of his surplus for the general betterment of his standard of life. But where the examples of those who have had greater opportunities and greater income are constantly before the worker and his family, the transit from the old to a new standard comes with no great delay. New desires are felt which demand all the increase of income and more. Thus occurs the constant and insistent pressure from below for a better standard of living, which is so marked a characteristic of the civilization of Western European peoples.

But in tropic or semitropic lands, such as Mexico, the conditions that surround the laborer do not produce, or at least have not heretofore produced, that wholesome unrest which is the dynamic element in countries less favored by nature. Life is too easy. Poverty is always near but actual starvation is known hardly by report. Contrasts in habits of life outside the larger towns are not so great as to furnish incentive to enterprise. The working man feels himself a part of the community and occupies a traditional position within 
it. He is not conscious of great wrongs nor disposed to question the fitness of things as they are.

Nominally all labor in Mexico has been free during the entire life of the republic, but the desire of employers to secure a lever by which the Indian could be induced to work brought the continuance of a system inherited from colonial times which, while not legally slavery, had to a large degree the economic effects of a slavery system.

In this as in many other matters of public policy political theory outran practice. The constitution of 1857 under which the republic continued to live until the adoption of that of 1917 provided that "nobody should be obliged to render personal service without proper compensation and his full consent," and prohibited laws that sought to recognize contracts involving the "loss or irreparable sacrifice of the freedom of man through work, education, or religious vows." These clauses were considered to abolish the prevailing peonage system. On September 25, 1873, the rule was made to read: "The State cannot allow the fulfillment of any agreement, contract, or covenant which may, in any manner impair, destroy, or irrevocably sacrifice man's liberty either through work, education, or religious vows." 1

Neither clause brought a change in fact. Local efforts to make the law square with practice did not up-

1 The above quotations are from Matias Romero, "Wages in Mexico," published in Commercial Information Concerning the American Republics and Colonies, 1891, Bulletin No. 41, Washington, 1892. 
root the well established characteristics of the employment contracts. It is true, of course, that labor conditions during the Diaz régime varied widely in different parts of Mexico. The men were not uniformly good workers, they were not uniformly content with their lot as they found it, and the conditions of their employment varied with the traditional arrangements observed and with the degree to which foreign influences had come in to upset the unprogressive but generally contented habits of the slow-moving local life. But none of these influences created a general demand for betterment of the condition of the laborer. The labor problem was in the greater part of the republic one which, to the employer, meant how to get labor, not how to satisfy the demands of an organized labor class.

The Mexican government has never had a thorough study of the labor conditions among its own people. It does not know officially to-day in more than the most general way the usual terms of contract, the wages, or the living conditions of the laboring classes. The best picture that can be given must be based on incomplete official surveys supplemented by the observations of travelers, the experience of the many foreigners who, in their enterprises, have come into contact with the Mexican peon, and the testimony of those who have been prominent in support of the recent labor movement or in its opposition. In the years 1885-8 the government published the results of a labor survey of Mexico which is even up to the present time the most comprehensive effort of the sort that has been made in the republic. Though the answers to the questionnaires 
sent out are by no means of even merit, they give a fair picture of the status of the Mexican laborer in the early part of the Diaz period. ${ }^{2}$

Complaints concerning the condition of the laborer were even at this early time frequent. The discussion shows that the desire for change did not come from the peons, who were, in fact, then and later as a class unprotesting and fairly well satisfied. The labor system was criticized rather as a factor in the national life which was neither economically efficient nor one which promoted the creation of an independent citizenship.

The reports that were asked from the officers of all the states and their subdivisions reveal a surprising variety of customs affecting the labor contract. There was no generally accepted system of peonage. Rates of pay often varied greatly in communities at short distances from each other. As a rule the contract was for shorter periods in the south and the wages were better in the north. The enterprises in some districts furnished only seasonal employment for a few men and employers found it difficult to secure help even on these short-term contracts. In other cases there were two, three, and even four different kinds of servants recognized, each with their separate wage arrangements.

In some communities pay was by the task or by the day in advance, in others by the week in advance. In others, payment came at the end of the period of serv-

2 These reports were published in great detail in a series of documents with slightly varying titles in 1885-7. The general title is Informes $y$ documentos relativos a comercio interior $y$ exterior, agricultura $e$ industrias. 


\section{MEXICO AND ITS RECONSTRUCTION}

ice. There were year, two-year, and even five-year contracts. There were share farmers of various kinds and casual laborers. The longer contracts might or might not involve such elements as ration, the furnishing of tools, clothes, medicine, housing, and a large number of other elements. To speak of Mexican peonage as a system was to use a misnomer. Nothing less deserved the name. It was a tissue of widely varying rules partly resting on state legislation but largely on local custom, the origin of which was not found in written law even in the colonial régime.

Study of wage rates, though they are carefully reported in the inquiry referred to, does not allow definite conclusions. Actual income in one district as compared to another was not measured by the money wage. Ration allowances, land for the peon's use, and hunting privileges modified conditions. A centavo had a very different value in Chiapas from that which it possessed in Durango, the wants of the peon in the one case were fewer than in the second and he would stop working sooner, no matter what the wage offered.

It is also impossible to give any intelligent discussion of the hours of labor in a country where presence on the job has such an indefinite relation to the work done. This is true in all non-industrial countries in which there are wide variations of climatic conditions. The peon started work in many districts at four in the morning. He finished at eight at night or later. The working hours were variously reported within the 16-hour period. Yet the number of Mexican laborers who worked straight through the reported working period or straight 
through the day, except for meal hours, was small indeed. There were rests, lunch periods, siestas, periods for smoking, and the unavoidable interruptions that seem to be inherent in the work of any aboriginal or semi-aboriginal labor group. All these made the actual effective labor hours much less than their nominal total.

There were so many variations in labor conditions that no average standard can be discussed without destroying the most distinctive feature of the picture, its variety. Illustrations from the south, the center, and the northern part of the country at various periods give a fair idea of the sort of contrasts encountered.

In Chiapas in the Department of Pichucalco in the middle '80s the laborers were of three classes: free and debt servants and intermittent workers. The first received 25 centavos and subsistence, or 38 to 50 centavos without subsistence. Such servants were hard to find. Few "liked to work by the day."

The debt worker presented himself to the intending employer and received an advance of wages and a socalled card account, carta cuenta, stating the amount owed. This was recognized before a legal authority, before whom was also drawn up a statement of the term-regularly one or two years-for which the man agreed to work every day but feast days. The proprietor promised to pay the wages agreed upon, furnish stipulated food, and make the necessary advances in cash, clothing, and tools. Often the formal legalization of the contract did not take place, the card account being issued and both relying on custom to determine their rights and duties. The services of the wife might 
or might not be included in the laborer's contract. When the laborer wished to move to another farm, he made arrangements with its owner by which the latter would pay the former employer the amount of the laborer's card account. The man was then transferred. The advances on card accounts often reached 500 pesos or more. The wage of the debt laborers in cash was four pesos a month, in addition to which they received 500 ears of corn, 20 pounds of beans, salt, house rent, medicines, and two bottles of alcohol.

The intermittent workers were bound to work only four days out of each week. They received lodging and four pesos a month without any supplemental allowances.

In other parts of Chiapas still other variants were found. In some districts there were meseros, or month workers, usually Indians who owed more than they could pay. Their contracts differed from those of the debt servant above described in that they worked one month for the master and one for themselves. They did not live on the farm but in their own homes, which were often distant from the place of work. As in the case of the other debt peons the master assumed their debt and paid them their wages and a ration of corn. Another class were the baldios, who lived on the place but worked land for themselves, built their own houses, and paid from two to four days' labor per month for their privileges. They were under obligation to work for the master for a peso or nine reales a week when he called upon them. Occasionally there were share workers and advance-payment week workers. The best paid 
laborers on the haciendas were a class called punteros, a sort of foremen found only on the larger places. They distributed the tasks of the day and themselves worked with the group of men of which they were given charge.

The labor difficulty in the south was then what it is to-day. Life was too easy to encourage habits of industry. The great majority of the population were Indians who felt no necessity to work. Only a few of the native towns furnished laborers. The people of the rest of the towns relied on their corn patches and hunting for their livelihood. In the average case, there was little oppression possible on the haciendas, since the Indian could escape and the arm of the administration was not strong enough to hold him to his duty. The landowner had to do the best he could to keep peace with his laborers and by various expedients try to induce them to work. The scarcity of voluntary labor made the temptation to force the Indian to work greater and, where the employer could get the effective aid of the authorities, abuses of this sort were not infrequent. Some of the worst wrongs of the peonage system occurred in the southern states. ${ }^{3}$

A very large share of the population in the southern states worked for no master and but little for themselves. They were satisfied with their native villages in which there were few social necessities. They lived in palm leaf houses, they needed almost no clothing. What little they used the women wove from local cotton in the hot lands. Those from the colder plateau districts

${ }^{3}$ See Wallace Thompson, The People of Mexico, New York, 1921, p. 325 et seq. 


\section{MEXICO AND ITS RECONSTRUCTION}

obtained cotton by trading fruit or other natural products for it. A few had flocks of sheep.

The diet of these people was chiefly corn, beans, fruits, and game. They bought salt and occasionally beef. The chief indulgence was alcohol. They were all but self-sufficient, they were almost untouched by taxes, unaffected by commerce and industry. Among such a population labor was scarce though potential laborers many.

In some of the southern states work by the task, the so-called faena, or tarea, was frequent in the middle '80s and in some municipalities it was the only way of hiring labor. In Cuaatla, Morelos, in one of the sugar districts there were day and task laborers. The latter did a set amount for 25 centavos. An active man could do three tasks but most stopped after doing one or one and a half, although the day laborers might still be at work. Those who worked by the day were of two classes. Both worked all day. Those of both classes were required to do a certain amount of work before sunrise. In the afternoon those who did not live on the estate had to do another equal task completed by eight o'clock on regular week days without increase in pay. On the other hand, they could come to work at noon on Monday and stop Saturday afternoon at two or three. All the men were paid twice a week, on Tuesday what they had earned to that time, called the socorro, and on Saturday the raya.

Farther north in the State of Puebla some laborers worked by the day or week for $311 / 4$ centavos a day during the unusual stress of hay or wheat harvest. Those 
who worked by the year, the contract regularly beginning with Holy Week, were paid at the rate of 25 centavos a day. At the beginning of the contract the employer took over the laborer's previous debts, gave him clothing for the season-an act repeated on the first day of November-and a certain amount in cash. He was obligated to give the laborer 50 centavos a week for spending money and one cuartilla, about 1.38 liters, of corn for subsistence. The employer paid the unusual expenses of the peasant for such items as medicines, wedding and saint's day celebrations, and the like. The peon received the use of a quartern of land, seed, and the tools needed to work the land. Fuel for his domestic use was also furnished.

The lot of the debt laborer in the north appears to have been less favorable than in the south. In Coahuila the harsh legislation formerly in force was nominally softened by the provisions of the constitution of $\mathbf{1 8 5 7}$ and by a new servant law of January 28, 1868, which forbade advancing to a servant in a year more than he could pay back in six months. This was intended to protect the peon against his own improvidence. The rule was not obeyed. The masters continued to advance large sums to hold the men as before. On the 20th of February, 1881, another servants' law was passed. The master could not dismiss the servant without eight days' notice nor could the servant leave without paying his debts. An increasing number of disputes involved this latter provision. For the servants it was claimed that it was contrary to article five of the Constitution of the republic, but in practice the authorities required a run- 
away servant to return to the employ of his creditor on the ground that to abandon employment violated articles of the penal code and the law of servants. ${ }^{4}$ If a trial resulted, the servant appealed to the Constitution for protection. Efforts were then regularly made to settle the case by compromise. Masters feared that if the Constitution was held to apply all servants might repudiate their debts. Servants were indisposed to run the chance of having the criminal sentence declared against them.

There were many variant contracts in the north as well as in the south. For example, in the district of Comonfort, municipality of Chamacuero in Coahuila, three sorts of share farmers were found. Renters might receive from the hacienda owner the use of the land, the seed, a yoke of oxen, and a load of grain to be paid back at harvest time. The renter paid one-fifth of the expenses in harvesting and received from the harvest one-fifth less than his half. By another plan the yield was shared equally, the owner furnishing the land, the seed, an ox, and half of all expenses including those of the harvest. If the laborer received land, seed, a yoke of oxen, one peso 50 centavos in cash, and a load of corn, these last not to be paid back, and did all the work, he received one-fourth of the crop. ${ }^{5}$

During the progress of the Diaz régime there were,

${ }^{4}$ Penal Code, Art. 407; Law of Servants, Article 10.

5 The description of the labor contract in Coahuila is well detailed in Informes $y$ documentos relativos a comercio interior $y$ exterior, agricultura é industrias, Number 10, April, 1886, Mexico, p. 92 et seq. From this series the other illustrations given above are taken. A very excellent discussion of wage conditions in Mexico in 1891 is given in Matias Romero, op. cit., pp. 125-45. 
of course, marked changes in labor conditions. No great economic transformation such as that which marked the period could occur without disturbing the entire network of human relations upon which the national life rested. Nevertheless, the change in the labor contract was less fundamental than apparent. Cities grew, commerce increased, and the nascent industry of the ' $80 \mathrm{~s}$ achieved an importance in the public economy never before known. On the routes most visited by foreigners there were many evidences of the passing of the old and the coming of a new economic day. But in the back country life was still stirred from the accustomed routine only in a secondary way. Local customs continued, legislation intended to bring the nation into line with the developments in the Western World was added as an embroidery or flourish, but it did not replace the habits of generations. It was not fundamental in character. The position of the average Mexican laborer was still one of status not of contract.

The labor arrangements found in later periods in different parts of the country indicate the degree to which the relations of employer and employee remained unaffected by the developments which were transforming the life of the nation. They show also modifications which the new conditions introduced in the labor contract.

In Yucatan, at the end of the Diaz régime, debt service was still a characteristic of the labor system. It was still illegal but seldom questioned. The large hacendados, or owners of haciendas, aimed to keep as many laborers living on their plantations as they could. Many 


\section{MEXICO AND ITS RECONSTRUCTION}

of the servants. on the better managed places had been born there as had their fathers. They were paid, in some cases, at a fixed rate under period contracts; in others, a daily wage according to the number of henequen leaves cut and piled-the raising of henequen being practically the single local industry. The laborers received houses, garden plots, and medical attendance free. The masters, in some cases, supplied rations of corn free; in others it was sold to the laborers at less than the market price. It appears that there was little dissatisfaction with the system in this state on the part of either the men or their employers. The state was but little stirred by the revolution when it came, in fact it took no part in the effort to overthrow the old régime. It was not until after 1914 that the revolution affected the laboring population. Even then they were roused against their employers only by insistent propaganda backed by those in control at the capital.

Chiapas, in the latter part of the Diaz régime, was still without a sufficient labor supply for its development. An American manager for one of the large plantations declares that his company and all those surrounding were so anxious to have labor available that they were willing to give a plot of land to any Indian family that would work it. Any land hunger on the part of the native could thus easily be satisfied. About 150 families were settled on the estate in this way. Generally the Indian in that region did not want a definite piece of land, he wished only to burn over a field and get one or two crops from it by planting directly in the unplowed soil. When grass and brush began to ap- 
pear, he abandoned the field for another, which he could prepare by burning it over, a process easier than plowing.

Whether given land on a plantation or living in his own village, the Indian was loath to work. Reliance still had to be on a system of induced labor. In this region the majority of the Indians had to be secured from communities in which the men had their own corn patches, wheat fields, pigs, chickens, and perhaps even their own cotton and sugar. The plantation owner had no legal authority to force these men to work for him, but by long-established custom every able-bodied man could be called on to work one week in four. Laborers had to be summoned to work and in this the civil authority gave its support to the requests of the plantation owners.

In actual practice in this region the plantation owner hired a man who could speak Spanish and, preferably, the native dialects to do recruiting. A man representing the civil authority would accompany this person on his rounds or the jefe politico might give him a letter to the head men of the native villages from which the labor was to be drawn. These head men and the jefe politico knew how many men there were in each village, how many had been requisitioned, and whether there was a balance. Notice was served on the head man and he would see that the Indians promised reported. If he were reluctant, he was sometimes given a tip. Those from each village arrived together, worked together on the plantation, and left together. Once on the plantation they would usually stay from four to ten weeks un- 


\section{MEXICO AND ITS RECONSTRUCTION}

der special inducements, but they were free to go after one week. Payment was made directly to the man at the end of each week-by the piece system or at one dollar Mexican per week, if employed on that basis.

The day's work bore a strong contrast to that in industrial communities. The men were rousted out between six and seven in the morning, they came to a central house where they received a drink of sugar cane rum "forty drinks to the liter and so strong you could burn it in a lamp." Each man got all the beans he could eat, half of a large corn cake, and a ball of boiled hominy, which latter he took to the fields with him for his three lunches at nine, twelve, and four o'clock. At noon there was a two-hour rest. Work was, as a rule, by the tarea system. There were frequent interruptions. Though they were paid by the piece, the men had to be followed up constantly or they would loaf and play. On the average the work day was about nine hours. Returning at night each man received another drink of rum, all the beans he could eat, and the other half of his corn cake.

Along with these Indian laborers there were often employed in Chiapas another group, generally with some mixture of Spanish blood, who worked under contracts more nearly approaching the peonage system as usually reported. The man who wished to become a peon came to the employer and asked for a loan under the usual employment contract. This was given. Then, if the relation was newly established and the man was without family, he disappeared for an agreed period. This time passed and the money gone he reappeared, 
settled down on the ranch, and became a fixture. Soon he had a wife, a garden plot, some chickens, and a pig or two. He worked during the week and on Saturday night appeared for his wage balance, if any, which he proceeded to spend on the simple but powerful luxuries to which his generation was accustomed. Generally he did not try to pay his debts but to increase them. To have a heavy debt was for many a sign of standing in the community, an evidence that the employer had confidence in the employee.

In the latter part of the Diaz régime, in some of the sugar and coffee plantations of Vera Cruz the day labor, task and share-rent systems were apparently gradually displacing the classic form of peonage. A French plantation operator employing between 700 and 1,000 workmen in the low lands worked his fields by means of men recruited chiefly from the higher altitudes. Many of his neighbors had adopted the share-rent system of employment. He himself preferred to get his labor through capitanes to whom he paid five per cent of the wages of the day laborers as premium. Of these laborers about one-fourth were induced to live on the estate, the rest were casuals paid 50 cents Mexican per tarea or from 56 to 72 cents Mexican, if on a day labor basis. In this district, as elsewhere, the lack of ambition was alleged to be a prominent characteristic of the laborer. He would not do more than one tarea though he could easily do two. Those who lived on the estate, though they were given garden plots, seldom cultivated them efficiently and the share renters, when the return for the season's harvest was paid them, almost without 


\section{MEXICO AND ITS RECONSTRUCTION}

exception squandered their earnings in the most improvident manner.

An engineer formerly employed by the Mexican government reports that labor conditions in Tamaulipas were practically the same in 1910 as they were a generation before. The money wage had risen to from six to nine pesos a month but the historic system controlled the labor contract. The laborer could not leave until he paid his debt. Once in debt, he could only with great difficulty get out and, if not in debt, he could only with great difficulty remain so. Peons were given a credit account which, on account of advances usually made at the beginning of the contract, always showed a debit balance. They sometimes received the right to live in a house owned by the employer, sometimes they built their own bush shacks. If they were ambitious, they could regularly have land for a garden, but they seldom did so.

These illustrations for both the earlier and the later period of the Diaz régime are samples of widely varying practices in which there was an underlying similarity in that the contracts were not free will engagements. In this sense they are typical of the conditions under which a large part of the laboring population worked. They are not typical in other respects, because the labor contract in different parts of the country and even within the same region was of such varied character that there was no type.

Though peonage was found in widely separated parts of Mexico, both at the beginning and at the end of the Diaz régime, it is a mistake to consider it to have involved all the population at either period. A consider- 
able number of the natives were never touched by it and, especially with the development of the economic resources of the country, there came into existence, in the larger cities, along the railroads, in the mines, textile working communities, oil fields, and elsewhere a class dependent upon the wage system such as it is known in other countries. These workmen lived, as a rule, under conditions less favorable than those found in the United States. They were better off, however, in both living conditions and wages, than the average Mexican laborer. They seemed to be the beginning of a labor class similar to those found in more advanced communities.

The pictures that have generally been drawn in the United States of labor conditions in Mexico at the end of the Diaz régime are unfair. A great deal of sympathy has been wasted on that portion of the Yaqui tribes that was transferred from the northwest to Yucatan and Campeche, though there were undoubted abuses committed in the process. There were, in certain regions in the southern states, labor conditions altogether indefensible but they were not general. The "shanghaiing" of men from the cities, especially the capital, for work on plantations on the isthmus of Tehuantepec seems to have occurred in a large number of cases but such practices were not a real part of the peonage system. ${ }^{\circ}$ The worst abuses of this sort, roundly denounced by all responsible Mexicans, appear to have occurred in the Valle Nacional of Oaxaca. Such conditions involving the herding of the victims into barbed wire en-

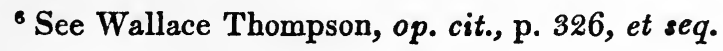


closures and various methods of inhuman treatment were exceptional, probably not more typical of Mexican conditions than the story of Simon Legree was typical of conditions in the southern United States in slavery days.

That the labor system in force in Mexico was a drag upon the development of the country was frankly recognized by forward looking Mexicans. None have been its more acrid critics. Many are the telling contrasts which they have painted of the conditions to be found north and south of the Rio Grande. Representative of these criticisms are the following: "On the border there is decent labor, supported by justice, with the rights of man vibrating in every nerve and in every drop of blood; the agriculturist with his hide boots and his wage of two dollars gold; the laborer who works in the fields by the day, who upon his return home at night, clean and happy, takes to his arms a flock of strong children." South of the river "is savagery, dark and brooding, a silent barbarity . . . which asks nothing of light, a surrendered right which asks nothing of happiness, a weakened constitution which asks nothing more than a drink of alcohol . . . and five ounces of caustic stuff in the stomach; a paternity without sovereignty, a home without rights, an unhappy wife; a nominal country, slavery - at the price of 100 to 200 pesos. . . ." "The peon is a drunkard because of hunger; by custom, by exploitation, ignorance, dissimulation of the authorities, and because of his tendency to laziness. . . The family of the day laborer ... does not exist ... the children if . . . they escape tuberculosis, hardly reach 
the age of maturity before they ... inaugurate . . . ... the . . . life . . . that they learned from their parents." "The world has never known a school before a home . . . and if we are to believe our eyes, that among the jornaleros, or day laborers, the family does not exist, the first thing that we must do is to create it." Under the unfree labor system economic independence is impossible. "As long as the jornalero cannot eat meat, as long as he cannot support his children through school age, as long as he is a legal slave . . . he will not be a civilized man ... ."

There have been apologists for peonage both in and out of Mexico. By them the system is pictured as not only an essential for the economic development of the country but as a kind paternalism which is a positive benefit to the native. Through it he is taught the habits of industry, he is introduced to the wants that will make for his own betterment, he is given advances when his necessities are greater than his slender means, he receives assistance when crops fail and medical attendance when his family falls ill. Instances are cited in which the laboring classes have protested against a change to a daily wage system that would break the relationship of protector and protected and throw the latter out upon the mercies of the world.

It is unnecessary to prove that there are cases in which the employer has made his relation to his Mexican employees a means for improving their lot. But though

${ }^{7}$ Quotations from speeches in the agricultural congress of the diocese of Tulancingo reported in Bolétin de la secretaria de fomento. Numero especial de propaganda, Julio, 1906, Mexico, 1906. 


\section{MEXICO AND ITS RECONSTRUCTION}

the induced labor system as an economic instrument has many defenders among employers of both Mexican and non-Mexican nationality, there can be no doubt that it lent itself to serious abuse, and that it encouraged the defects with which the laborer was charged. The wrongs committed are not confined to any single region. The better class hacendados, as a whole, themselves deplored the labor conditions, which they apparently took no determined steps to remedy.

The arguments of the defenders of peonage do not convince any large percentage of those who have observed the practices it developed. They are the same as those used in the United States before the Civil War to defend negro slavery. No social institution is entitled to be judged by what it might be if human nature were other than we find it or by the beneficent results obtained under it in isolated cases. Peonage is a survival in Mexico and an unwholesome one. Even if, as its defenders insist, its abolition will bring a slower rate of economic development than would otherwise be possible, there are nevertheless few in the more enlightened countries of the world who will hesitate to declare in favor of its abolition. No nation can afford to sacrifice the individual liberties of its people to secure greater economic advantage. Unfree service is a contradiction in the twentieth century and no effort to bring it to an end can fail to have the sympathy of those who hope to see the growth of true self-government among the nations of the world. 


\section{CHAPTER XI}

THE MEXICAN LABORER: HIS WAGES AND DEMANDS

In spite of the fact that nominal wages, as is indicated above, have so little relation to the real return to the Mexican laborer, a sketch is given here of the payments made at various periods in different parts of the republic. ${ }^{2}$ In some cases it is doubted whether the real wage in later years was any better than in the earlier part of the Diaz régime. Taken as a whole, however, it appears beyond question that the laborer was better paid at the end of the period than at its beginning. Only scattered statements can be obtained indicating the nominal wage rates in any pursuits at any time in Mexico. Humboldt reported in 1804 that the agricultural laborer received about 28 cents per day. In 1884, at the beginning of the railroad era, Adolph F. Bandelier reported that the Mexican received daily "as farm laborer 25 to $31 \frac{1}{4}$ cents; as railroad hand 50 cents." David A. Wells reported in 1887 that the wages of ordinary farm hands were from 18 to 25 cents per day, the better class of adults receiving 37 cents per day. The survey undertaken by the Mexican government, the results of which were published in 1885-7, showed a wider range-wages for men being in some cases as low as 12 cents and in others as high as $\$ 1.50$ Mexican. In

${ }^{1}$ See Wallace Thompson, The People of Mexico, New York, 1921, pp. 348-370. 


\section{MEXICO AND ITS RECONSTRUCTION}

1893 the Tro Republics, an English paper published in Mexico, stated: "It is officially announced that the average daily wage in this country is 27 cents." The paper declared that this was "probably at least 10 cents more than it was 20 years ago." In 1896 Matias Romero, one of the best Mexican authorities, stated that the average wage of day laborers was about $371 / 2$ cents.

Industrial wages have risen with the growth of Mexican industry. Official statistics showing the usual payments at various periods are not available. A study made just before the conditions of the old régime were upset reported about 117,992 persons as engaged in industry, of whom 100,717 were men and 17,275 women. ${ }^{2}$ The political divisions from which the greatest number of industrial workers were reported were, in order, Vera Cruz, the Federal District, Nuevo Leon, Jalisco, Puebla, Oaxaca, Mexico, and Michoacan. The least industrial regions were Tamaulipas, Lower California, Colima, Campeche, Chiapas, and Yucatan. Industrial wages were highest in the states which had the greater industrial development. The higher wages for men and for women were found in the states bordering the United States and in those in which the stimulus of foreign enterprise had most deeply affected the local life. This contrast is true, indeed, in agricultural as

${ }^{2}$ Of course, since there are no official statistics available for the making of which "industry" is closely defined, such statements as the above can only approximate the truth. There is no way of telling, for example, whether any attempt was made to include small household industries, though it appears they cannot have been covered. 
well as industrial wages. There was a wide difference between the highest and lowest wages in the same states. In many cases the better paid received five and even eight times as much as the poorest. Women were paid much less than men-as a rule rather less than the class of men workers who were most poorly paid. ${ }^{3}$

The highest wage reported as paid to any Mexican laborers in industrial work was $\$ 3.00$, the lowest 12 cents. The highest wage for women was $\$ 1.50$, the lowest six cents. No attempt is made to state an average-in fact the conditions surrounding Mexican labor are such that no estimate has great value. The lowest figures announced above, for example, may be for children and represent but few individuals. The highest were paid, it appears, in comparatively few cases.

The practice in individual industrial establishments or groups of establishments gives the best illustration of the upward trend of wages. In 1906, wages for adults in El Oro mine varied from $371 / 2$ to 50 cents a day. It seems to be the general consensus of opinion that prior to the revolution the average daily wage for farm laborers was about 50 cents. Unskilled laborers on the railroads received from $621 / 2$ cents to $\$ 1.75$ a day.

Laborers in the oil regions about Tampico received 75 cents a day in $1908-9$ and $\$ 2.00$ and even $\$ 3.00$ in 1914. The average wage of several thousand laborers in this district was announced as $\$ 2.10$. In the mining districts wages ranged as high as $\$ 1.70$ to $\$ 2.50$ per day,

${ }^{3}$ These comparisons are based on tables in Eric Gunther, Handbuch von Mexico, Leipzig, 1912, p. 179 et seq. The wage figures are in Mexican currency. 


\section{MEXICO AND ITS RECONSTRUCTION}

the average for the whole industry being not less than $\$ 1.00 .4$

The payrolls of one of the largest American construction companies operating in Mexico show that the prevailing wages of their peon laborers in 1909 and 1910 was $\$ 1.25$. In 1911 , the average was almost $\$ 1.50$. In 1912-13, the average fell gradually, reaching $\$ 1.25$ in the latter year. These figures are in Mexican currency, equal to about half the same amounts in United States gold.

The tendency of wages, both the nominal money payments and the actual return, during the Diaz régime, so far as indicated by the information available, seems to have been steadily upward. As a rule, the rates of payment were lower in the more thickly settled uplands. The highest average payments, these individual cases, like the general survey previously cited, seem to show, were found in the unhealthy lowlands and in the northern states where proximity to the United States and the prevalence of undertakings by foreign capital appear to have had a favorable effect. As a rule, the wages of laborers working for foreign corporations in the northern states were higher than those paid elsewhere. The mining and oil companies showed the highest average. The textile mills paid less but still at a rate appreciably above that for agricultural labor.

The wage conditions created by the revolution were so abnormal that a study of them does not allow any

4 The figures in this paragraph are quoted and summarized from a discussion by W. B. Parker, of S. Pearson and Son, 280 BroadTray, New York. 


\section{WAGES AND DEMANDS OF LABOR 139}

general estimate as to whether they were higher or lower than those paid before. Striking contradictions present themselves on every side. Wages-nominal wagesin some parts of the country remained stationary for months in the face of a rapidly depreciating currency. In such cases, of course, the laborer, since the nominal cost of living went steadily up, received less and less. As one employer in the Puebla district has declared: "the men kept on working for months when a week's wages would not have bought them a bowl of beans." When the readjustment to the depreciated currency came, there had occurred also such an unsettling of prices that nothing can be stated as to the actual effect on the economic status of the laboring classes.

In this and other regions, when the local peasantry refused to continue work on the plantations at the old rates, the employers who were able to keep control of their property and keep it going had to raise the wages several hundred fold, in many cases so much as to constitute a real as well as a nominal increase.

In still other areas the laboring classes, or those who claimed to represent them, having secured control of the government, were able to profit by the peculiar circumstances of the local industry and to demand extortionate prices for whatever labor they performed. The best example of this condition was found in Yucatan. The spectacular rise in the price of sisal, due to the conditions created by the World War, and the exploitation of the hacendados by the revolutionary government put the agricultural laborers in a position to demand wages comparable to those paid before the war in highly 
developed industries in Europe and the United States. Prices were also extortionate. Ice cream sold at the equivalent of 45 cents United States currency a plate, chewing gum at five cents a stick, pears at 40 cents apiece, and small tin cans of fruit at $\$ 1.50$ apiece. Yet, for the time being, the most feverish prosperity was evident everywhere. The Chinese laundrymen used automobiles to deliver their customers' shirts, mestiza market women drove up and down the fashionable promenades of Mérida, the state capital, in coaches, and the local hotels charged prices far above those of similar character in New York or Paris. For the former peon, however, though the prices of what he consumed had also risen, the revolution, because of his increased wages, was at least a temporary advantage.

The old régime once upset is never reëstablished but it seems clear that coming back to work in time of peace, in many parts of Mexico, will necessitate painful sacrifice on the part of the laborer of many of the exceptional conditions he enjoyed during the upheaval of the revolution. It is equally clear, however, that the low wage level of pre-revolutionary days has gone forever.

The labor union movement in Mexico was only beginning in the years before the revolution. The government was indifferent to the rights of labor and discouraged rather than favored the efforts of the workmen to improve their conditions. The first important development occurred among railway laborers, whose union dates from 1904. There developed also, in connection with the nationalization of the railroads, a movement for the nationalization of the railway service. A 
policy was introduced, by which no more Americans were taken on in the railway service, though those already employed were allowed to stay. At first the new rule was applied to the lower ranks. The change to Mexican service came more rapidly than the rule demanded, since many of the Americans would not stay under the conditions that soon surrounded their work. As a result, by the end of the old régime, Americans occupied, with a few exceptions, only the higher executive positions. In other industries, especially textile manufacture, labor organizations sprang up but had only a weak and, almost without exception, ephemeral existence before the revolution. Even as late as 1908 the president of the Grand League of Railroad Workers reported the unions as including only the Grand League of Railroad Workers, 10,000 members; the mechanics' union, 500; the boilermakers' union, 800; the cigarmakers' union, 1,500; the carpenters' union, 1,500; the shop blacksmiths' union, 800; and the steel and smelter workers' union, $600 .^{5}$

During the revolution, labor organization increased rapidly. Unions of all sorts sprang up overnight under the leadership of men who recognized not at all the limitations of those in whose interests they professed to be working. Workers in mines and textile industries, stevedores, public employees, clerks, barbers, street car men, coachmen, waiters, and a large number of other groups, formerly unorganized, had their unions and, under the most irresponsible leadership, made de-

${ }^{5}$ From figures published by John Kenneth Turner, Barbarous Mexico, Chicago, 1910. 
mands upon the employers. This kept labor conditions generally in a turmoil.

The years of the revolution, with the exception of the period of control of Huerta, are ones in which there has been a rapid growth of labor legislation. The Madero government announced itself the champion of the downtrodden, particularly of the laboring classes. The Carranza government professed even greater enthusiasm in their defense and improvement of the condition of the laborer has been at least nominally a part of the political problem of its successors. The Madero government created a Bureau of Labor, which subsequently became a Department. It intervened in a number of strikes and succeeded in getting better hours and wages for the laborers in the textile industry. No important labor legislation was passed in the latter part of the period of Madero's control, though a large number of proposals were made to Congress.

When the radicals came back under Carranza, the demand for labor legislation became insistent in both the central and the state governments. The supporters of the government included the great majority of the young radicals. The measures taken with the announced intent of helping the workers had a wide range and were often little short of fantastic in their operation. It is impossible to digest them. Examples illustrate their general trend. There were efforts to prohibit bullfights, cockfights, lotteries, the pulque trade and even all liquor production. Not all the country would follow the lead of those who wished to do away with these alleged harmful diversions, and some states, 
which professed to do so, did not enforce the laws passed strictly. The effort to do away with the pulque trade in the federal district, for example, became one to reduce the number of shops where it was dispensed. Yucatan, which boasted itself a dry state, was so on little more than the surface.

Besides these general social legislation measures, there were others designed to benefit labor at the expense of the hacendados, and factory and mine owners, and, in fact, all the interests that were looked upon as representing the capitalistic régime recently overthrown. Hours of labor for men, women, and children; rates of wages; peons' wages; peons' debts; employers' liability; settlement of industrial disputes; the holding of large estates; and an indefinite list of similar subjects were regulated by new legislation. Often these measures adopted the most advanced standards of legislation found in European countries or the United States, too frequently they aimed to put into effect the extreme demands of the ultra radicals in these countries. There was little consideration given to the question of the applicability of the proposed standards to Mexican conditions.

Of course, some measures could be forced upon the interests affected under threats, such as confiscation of property or the taking over of its operation by the local governmental authorities. Others, for example, those involving land settlements, could be pushed through by taking property under at least the form of legal process and distributing it to the persons, whose rights, it was alleged, former legislation had disregarded. This, for 


\section{MEXICO AND ITS RECONSTRUCTION}

example, was done in numerous cases in the State of Puebla. In other cases the legislation was so unsuited to local conditions that it resulted in little more than arousing the hopes of the laborers only to disappoint them and to make social conditions on that account increasingly difficult.

While these developments were in process, the Constitution of 1917 was adopted. It reflected the conditions amid which it was drafted. Many subjects that are obviously ones that should be handled by legislative authority were crystallized into the new "fundamental law" in the attempt to guarantee to the humbler classes of the population rights that it was feared would not be assured if left to be guaranteed by ordinary legislation.

It is not to be wondered at if the agitators of the revolution found the Mexican laboring classes fertile ground for propaganda. The agricultural laborer, who is still the typical laborer in Mexico, had little to lose by the disturbance of the social order. He received the minimum of subsistence and a revolutionary band offered him at least that plus diversion which, even if of a rough sort, furnished an acceptable contrast to his daily life. Though he was not at heart dissatisfied, the glowing picture which the revolutionist orators painted was so attractive that it overcame his native conservatism. That such men joined the revolution blindly and without a clear conception of what their specific grievances were, nor of the means by which they could be righted, is doubtless true. That they joined at all is significant. The fact that there could be aroused within them a 
spirit of revolt against the conditions under which they lived was an indication of the possibility of awakening new desires, which, properly guided, may prove one of the means through which the economic life of Mexico may be transformed and the foundation laid for 'a new system of government more nearly approaching the democratic standards to which Mexico aspires.

Among industrial workers there appears to have been less voluntary enlistment in revolutionary activities proper but the disturbed conditions, which marked the passing of the old régime, were not without important effects upon their labor conditions also. The changing fortunes of the revolutionary leaders brought to various industries alternating periods of great activity and slack work. Labor organizers found those working in industry ready listeners, as easily molded as the peons. Long established custom was being broken down all around them. This was the dawn of a new day. The standards of hours, wages, and living conditions enjoyed by laborers in other lands were pictured in glowing colors. The Mexican workman could enjoy the same blessings if he would but reach out his hands.

That there were abuses in the industrial life of Mexico, even though it was but little developed, is beyond dispute. The quickest way to bring remedy to wrongs of which any class is conscious is, of course, for that class to put pressure on those responsible and this the industrial workers were assured was their opportunity. Unfortunately the labor leadership in Mexico, even if of good intentions, was far from wise. It was, it appears, chiefly of Mexican origin, irresponsible and lead- 


\section{MEXICO AND I'TS RECONSTRUCTION}

ing an impressionable following, whose hopes all the revolutionary governments appear to have done much to encourage. It is not to be wondered at if the conditions that developed were often weird in the extreme.

In the textile mills, for example, syndicates set out on an ambitious program the most remarkable thing about which, considering the character of the elements from which it received its support, is not that it has not worked with any marked degree of success but that it had the measure of success it did achieve. The unions forced from the mill owners successive increases of pay, they put pressure on the workers that made them all join the syndicate. They succeeded in unionizing shops with remarkable rapidity. They established resistance funds by levy on the income of each man, which were used not only for carrying on the fight against the local employer, but even in aiding the strikes of fellow workmen in other cities-witness the support furnished by the workmen of the Rio Blanco Mills to those of Puebla in 1918.

The extreme methods of class warfare were common. Sabotage by cutting of cloth in the textile mills was frequent. Theft of yarn and cloth reached a point never before approached. Inspection was ineffectual because inspectors were intimidated. The guilty caught in the act could not be convicted, because the laborers controlled the courts. In the old days the workers declared they were nothing in the government and the employers were everything. Now the shoe was on the other foot.

Neither the leadership of these movements nor their methods deserve approval. Neither could have had 
such wide success as they achieved among a working population truly awake to its own interests and dealing with a responsible government anxious to advance the interests of the people it served.

Nevertheless, here as in the protest of the agricultural population, although the dissatisfaction with old conditions resulted in a following of irresponsible and ill-advised leadership and the adoption of indefensible methods to try to secure laudable ends, the fact that the dissatisfaction with the old system did result in protest is encouraging. A laboring population that meekly accepts every rule made by the employer is servile. The first requisite for a fair adjustment between employers and employed is the recognition by both that each has rights and responsibilities.

Before the Mexican laborer can enjoy the solid benefits that should come to him from the break-up of the old régime and enter a working world in which he will enjoy greater independence and greater rights than he has had heretofore, he must unlearn much of what his teachers have taught him. He must first of all learn that greater independence means greater responsibility and that privileges are paid for by sacrifice. The old system had much that was indefensible about it, the ideals toward which his self-appointed leaders turned his ambition were often impractical. Those who are intelligently to lead the Mexican laboring classes to refuse to allow the return of the old abuses and to avoid new ones have a delicate task before them. It is one that is the more difficult because of the present limitations of those whom they attempt to serve. 


\section{CHAPTER XII}

\section{THE MEXICAN LABORER: HIS OPPORTUNITIES}

IT is safe to say that no great colonizing power ever handled the land problems that confronted it in a new and sparsely settled territory in a way that later generations have found satisfactory. To those who, in the age of discovery, set out to increase the national domain, the home governments gave grants of what they found -land. Had these large early grants, often with the most indefinite boundaries, continued in the hands of their original owners they would have been a great abuse in practically all the colonies of the world. But they very seldom did so. The estates fell apart by their own unwieldiness. Accumulations of property by institutions, notably the church, often held together to a greater degree but even these in most cases later broke up by the development of new economic conditions or by political measures directed against the holders.

Mexico is no exception to the rule. The grants of the colonial period are not the cause of present-day land problems, nor is the church an element that complicates agrarian conditions. The land question of the republic is of its own creation. To it three elements have prominently contributed, the tendency of the upper classes to put their capital into land rather than into industrial ventures, the breaking up of the communal land hold- 
ings of the Indian communities, and the disposal of "unoccupied lands" by the government.

Many of the great estates in Mexico arise from a characteristic common to many countries of Spanish civilization. Wealth is considered by the local society to be synonymous with landed property. Extensive real estate holdings give a family position to a greater extent than other forms of capital. The preference does not depend only on the belief that real estate is less disturbed by revolution than industrial property. It is due, also, to tradition. There can be no doubt that many of the large estates, because of their very size, have been a burden to their owners and that smaller areas could have been better administered and made to yield a better net return. Of the three elements above mentioned this is, however, the least important.

The Spanish land policy included the granting to the Indian villages of certain areas, called ejidos, which were held in common. This practice was inherited, and for a generation continued, by the republic. In the law of June 25, 1856, steps were taken for the distribution of community lands in lots of the value of $\$ 200$ or less. No measures were taken, however, to insure that the new proprietors should be instructed how to cultivate their lands to the best advantage, nor was legislation enacted to prevent the prompt alienation of their holdings. ${ }^{1}$ As a result, a measure intended to stimulate

1 The abuses practiced especially in the north and west in the disposition of the community lands are described by R. B. Brinsmade, El latifundismo Mexicano, su origen y su remedio, Mexico, 1916. 
individual initiative and to encourage Indians to become citizens of the republic, with rights and responsibilities similar to those of the more enterprising classes, failed. The lands were sold and the native, who formerly had, in his communal rights, at least a claim on a living of the standard to which he had been accustomed for generations, was thrown on the community landless and dependent.

The policy that resulted in this state of affairs has been condemned both in and out of Mexico and the revolution favored attempts in all parts of the country to restore the old status. Such steps have not succeeded. It is seldom possible, after any important change in social or economic relations, to turn back the clock and start anew. It is very doubtful whether it would be to the advantage of Mexico to reëstablish any large portion of the Indian population on a communal basis of life. Land is never used to advantage, at least under modern conditions, where it is held in that way. Other countries, notably the United States, have made similar errors in trying to shift the indigenous populations too rapidly from the old to a new standard of life, but the step once taken can not be retraced. The failure to surround the elimination of the ejidos with proper safeguards has complicated the Mexican land problem, yet former conditions can not be restored by any legislative act.

In its desire to encourage the development of its agricultural resources Mexico found itself at the winning of independence in a peculiar position. It had large extents of public land, at least land that belonged tech- 
nically to the state, inasmuch as no one held legal title thereto. But a survey of the national territory had never been made and the public authorities of neither the nation nor of the states could inform inquirers where the "unoccupied" land lay. In fact, land legally unoccupied might have been actually subject to possession by individuals for generations.

The obvious first step, if private property rights were to be given adequate protection, would have been to carry out a government survey of the territory and to try to protect those who were ignorant of the insecurity of their titles. Unfortunately the government did not feel itself financially able to adopt this plan. Until after the middle of the century there was no plan upon which action had been taken sufficient to allow it to be called a national policy for the management of the public lands. In 1863 a law was passed outlining the conditions under which individuals might secure ownership of the terrenos baldios, unoccupied lands. For the moment, however, the French intervention kept the policy from any practical application. With the restoration of the republic in $\mathbf{1 8 6 7}$ sales became important. By 1876, an area of 1,376,169 hectares had been distributed, yielding, by the prevailing schedule of prices, $\$ 292,-$ 736.30. From 1877 to 1890 the lands were alienated at a much more rapid rate. A total of 33,929,256 hectares were adjudicated, valued at $\$ 4,421,656.800^{2}$ The states in which the greatest distribution occurred in this

${ }^{2}$ Luis Pombo, Mexico: 1876-1892, Mexico, 1893, p. 39, from figures quoted from official publications. Other figures are published on p. 47 . 


\section{MEXICO AND ITS RECONSTRUCTION}

period were in the dry belt immediately south of the United States. In Lower California 9,800,000 hectares were sold; in Chihuahua, 9,000,000; in Coahuila, 7,000,000 ; in Sonora, 3,600,000; in Durango, 1,300,000, and in Sinaloa, 1,100,000. Up to the middle '80s practically all the lands distributed went to Mexicans. In 1883 the American Minister declared that no American in his senses would try to locate and claim any land because of the disputes for ownership that would be sure to follow. In the years that followed, however, the survey of terrenos baldios went on very rapidly by companies, native and foreign. They obtained shares of the land surveyed in payment for their work. The contracts were undertaken under the law of December 15, 1883, regarding survey anà colonization of public lands and under a series of laws passed between 1889 and 1894 known as the Leyes de Deslindes. These measures have been criticized severely for failure to protect the public interests. Up to 1889 there had been surveys authorized for $38,249,373$ hectares, of which $12,693,610$ belonged to the surveying companies, $14,618,980$ were segregated for various reasons, and 10,936,783 hectares, or some 26 per cent, remained at the disposal of the government. From that time to April, 1892, 3,011,440 acres were surveyed. Statistics for later years do not appear to have been published.

That there were abuses in carrying out the disposal of lands is beyond doubt. The "squatters" were frequently dispossessed of holdings of which they had long been in actual possession. The surveying companies which took contracts from the government often did 
their work in a haphazard manner and received very large grants in return for very small services. The government sold large areas at very low prices. Subsequent writers have been unsparing in their criticism of the policy that allowed such things to occur to the disadvantage of the public treasury.

It is doubtful whether the real abuse lies in the rate at which the lands were sold. After all, the settler who goes into a rough, undeveloped country creates all but a small portion of the value of the land he occupies and it is at least open to doubt whether a country in the position in which Mexico found itself might not well afford to give generously of her public land to actual settlers. The increase of the national wealth caused by their industry would be more important than the payments for the land.

The real abuses lie in the other circumstances sketched. The rights of those in possession were ineffectually guarded. The purchasers were not, as a rule, themselves settlers. Often their contracts provided that they must bring in families who would exploit the land, but these provisions were not enforced. In other words, though Mexico could have given her public land to settlers for small payments and still be considered fortunate, what happened was that many of her small farmers were dispossessed, and she sold her lands for negligible amounts and did not get the settlement that would have been her chief reward.

Under 79 contracts for colonization entered into between 1878 and 1889-about one-half of the total being made in 1883-4-only some 6,000 colonists had been 


\section{MEXICO AND ITS RECONSTRUCTION}

brought into the country. The number reported in 1892 was only 10,985, and the later years for which statistics are not available have brought no real improvement.

It is not possible to state exactly to what degree large land holdings came to prevail in Mexico before the revolution. No public record shows the development in a satisfactory way and discussions by private writers are almost without exception propagandist. That there were many enormous holdings and that they were an abuse, is beyond question. A few examples may be cited. Before the revolution Luis Terrazas was credited with holdings in Chihuahua of a larger area than the sovereign state of Costa Rica; other large properties were those of José Escandon in Zacatecas, Iñigo Noriega in Mexico, Garcia Pimentel in Morelos, Juventino Ramirez in Puebla, and the extensive possessions of the Madero family in Coahuila. In the sparsely populated Lower California there are some enormous extents of territory held by land companies. Three companies it is asserted acquired 93,798 square kilometers, an area larger than Ireland. Luis Haller and Company owned 53,950 square kilometers; the California and Mexican Land Company, Ltd., 24,883; and Flores and Company, 14,965. It is asserted that the 18 largest land companies had an average possession half as great as Portugal and that $\mathbf{1 1 , 0 0 0}$ haciendas comprised $\mathbf{8 8 0 , 0 0 0}$ square kilometers or 44 per cent of the total area of the republic. ${ }^{3}$ The state of Morelos is alleged to have de-

' R. B. Brinsmade, op. cit., pp. 10-13. See also Manuel Calero, 


\section{THE OPPORTUNITIES OF LABOR 155}

veloped the most intolerable conditions. Thirty-two men are reported to have "owned" practically the entire area. ${ }^{4}$

That the large estate system was not a wholesome element in the life of the republic the government of Diaz had recognized. The reports by the Department of Fomento protested against it. The economists of the country, while recognizing that there were certain regions that could prosper only under extensive cultivation and that certain crops could not, under the conditions obtaining, be profitably cultivated on a basis of peasant ownership of land, were in general agreement that some change must come. ${ }^{5}$ But their beliefs did not take form in action.

Unwillingness to attack the problem has not characterized the revolutionary reformers. The abolition of latifundismo has been a prominent part of their program. The end toward which they have declared their intention to work is one that meets general approval. The reasoning and the methods adopted, however, do not show that there has yet been worked out a land policy from which permanent improvement may be expected.

The central idea in the radical discussion of land problems during the revolution has been that the native popu-

Ensayo sobre la reconstrucción de Mexico, New York, 1920, p. 105 et seq.

${ }^{4}$ See a detailed but uncritical discussion of the land problem in F. Gonzalez Roa, The Mexican People and Their Detractors, New York, 1916, p. 1 et seq.

${ }^{5}$ Luis Pombo, op. cit., p. 44 et seq. 


\section{6 MEXICO AND ITS RECONSTRUCTION}

lation is inspired by a hunger for possession of land. One of the manifestos issued reads in part: ${ }^{6}$

The man of the fields was hungry and full of misery; he had been exploited beyond endurance and at last he took up arms to win the bread which the rich in their greed had denied him; to obtain possession of the lands which were in the grasp of the selfish proprietors. . . . He embarked upon revolution, not to win illusory political rights which fail to provide food, but to procure a bit of ground which would yield him bread, liberty, a home, independence, and a chance to get ahead. . . . The greater part, if not all of the territory, which must be "nationalized" represents land wrested from some small proprietors with the connivance of the Diaz dictatorship. The second aim is the restoration of these lands to their original individual owners, and to the .. pueblos. This great act of justice will be followed by presenting those who never had anything with a portion of the lands confiscated from the accomplices of dictatorship, or expropriated from the spendthrift heirs of the old land robbers, who do not even trouble themselves to cultivate their inheritance. Thus will the hunger for land and the appetite for liberty, which are felt from one end of the republic to the other be satisfied.

There is little to show that any such general land hunger exists among the peasant population. Except in a few districts desire for land on the part of the lower classes was conspicuous by its absence before the revolution and is not general now.

${ }^{6}$ The manifesto of Zapata from which these extracts are taken was published in the Voz de Juarez, of Mexico City, August 20, 1914, and later republished in part in the Reviere of Revieres, vol. 50 , p. 630, November, 1914. Though issued by the leader of the state where land hunger it is alleged did exist, the declaration applied to the whole of the republic. 


\section{THE OPPORTUNITIES OF LABOR 157}

The remedies adopted to eliminate the prevalent abuses are not above question. It is impossible to return the destroyed ejidos to their original owners, and to give them to their landless descendants, even when these can be discovered, is not a step that promises to solve the land problem. The measures for taking over land from the larger estates and dividing it among the peons are also too simple to inspire confidence. The fact is the land problem in Mexico is much more complicated than the revolutionary reformers seem to have conceived it. It is a psychological problem more than a physical one. The land hunger of the peasant does not now need to be satisfied, it needs to be created.

There are large areas in Mexico in which the price of land is still ridiculously low. The landowners complain of a lack of labor supply and many of them would welcome an opportunity to sell small holdings in order to get the laborers fixed in their neighborhoods. Such men could be counted on to furnish an auxiliary labor supply when their time was not demanded by their own properties.

It must be remembered too that most of the large landholdings are in regions unsuited to small ownership. In such areas the "forty acres and a mule" standard of property endowment, which was talked of in the United States for the Southern negro at the end of the Civil War, would be no measure of blessing to a peon. It would mean starvation for both the animal and his owner. In some of the regions, where large properties lie, irrigation might make small ownership practicable. But, unfortunately for Mexico, irrigation developments 
imply a technical ability and resources that the Government of Mexico has not been able to supply and will not be able to supply for a long time to come. Such developments require also the investment of large amounts of private capital. Until security for property can be well assured, investments of this sort will continue to be rare exceptions.

After all is said, it must be frankly admitted that a great portion of Mexico, if it is to yield as it should, must be held, so far as the present generation can see, in large units. Enthusiasts may prove the possibility of utilization of running water for irrigation and the storage of rainfall in huge reservoirs for the same purpose. By such means immense areas may theoretically be made highly productive and suitable for cultivation by small proprietors, especially educated for their tasks. The great majority of such schemes are, so far as our present knowledge of engineering and construction costs indicate, ones that will not leave the realm of dreams. ${ }^{7}$

Small land holdings, to be successful, must be set up where there is a desire for them. If the reformers turn their attention to the task of creating the demand for homesteads, they will have set their hands to a task, the importance of which it is almost impossible to overemphasize. No country that aims to be a democracy can overlook the importance of the conditions under which its real estate is held. Where there never has been

${ }^{7}$ See a discussion of the merits of various irrigation schemes presented and an interesting discussion of the colonization problem in general in Alberto Robles Gil, Memoria de la secretaria de fomento presentada' al congreso de la union, Mexico, 1913, passim. 
or where there has ceased to be a large class of property owners living on the soil they own, true republican government does not flourish. The possession of no other sort of wealth so surely stimulates respect for the rights of others and love of order and progress as does the possession of land. There is no other that makes its owner realize so clearly that the state is the guarantor of his well-being and that, by supporting it, he is working for his own advantage and for that of his community.

From this point of view there is, indeed, a land problem in Mexico. The average Mexican does not crave land ownership. He has not thought of it, because it is a privilege never enjoyed either by him or by his forbears. Giving him land alone will not create the desire to keep it. Any unguarded division scheme will soon disillusion those who foster it, because the small peasant ownership will vanish as did that created by the laws that divided up the ejidos. More than such a simple formula is needed: the creation of conditions that will give the Indian land, keep him on it, and stimulate his desires so that he will use it intelligently. Without this there will be no solution of the Mexican land problem worthy of the name. It is here that the land question shows its human side. It is more a problem involving the capacity of the population of Mexico than the division of its acres. Legislation can be adopted that will break up the big estates where that is needed for the best development of the country and legislation can help the landless to acquire land by loans of credit and the other expedients made familiar by, the experience 
of other countries; but the economic impulse cannot be created by fiat. It can be fostered by building up around the people a complex of social conditions that emphasizes the desire to enjoy the best that the community, offers. The love of family, the property sense, emulation of the economic success of others, the desire for influence in the community and for the applause of his fellows, pride in morality, public and private, these and an indefinite number of similar impulses must rouse the common citizen of Mexico, if the "land problem" is to be attacked with any real success. Whether a norm can be found depends more on the capacity of the Mexican people than upon that of its leaders. These latter can contribute to shape the conditions that may bring success, but all their efforts will be in vain unless the peon, and especially the Indian peon, shows capacity to become a citizen in fact as well as in name. He must forsake the economic, social, and civic childhood in which he has lived and take on the rights and responsibilities of manhood. 


\section{CHAPTER XIII}

\section{TRANSPORTATION}

Among the elements in the life of Mexico, each of which in succession seems to the student to be the key that will open the door for the establishment of a well rounded and stable civilization, are transportation facilities. $^{1}$

In the colonial period transportation was improved by the introduction of riding, burden, and draft animals and through the building of a few rough roads between the principal cities. But even at the end of 300 years of Spanish rule the number of pack trails was small and the important through wagon roads fewer still. What passed for roads did exist from Mexico to Santa Fé and from there to Vera Cruz. Between Mexico and Acapulco and from Mexico to Vera Cruz there were still only pack trails. The smaller towns were communities practically shut off from the rest of the country and a

${ }^{1}$ Only the internal transportation routes are here discussed. Ocean communication has shown itself more easy to adjust to the demands of traffic. The steamship services at the present time, too, are obviously less involved in the reconstruction in Mexico than are the roads and railroads. They are more easily reëstablished, their facilities have suffered less in the revolution and will rapidly respond to any development in the foreign trade. A description of the development of ocean communication with Mexico up to 1879 is found in Exposicion de la secretaría de hacienda de los estados unidos mexicanos de 15 de enero 1879 . . Mexico, 1879. 
large part of the burden bearing continued to be done by Indian carriers. ${ }^{2}$ In the rainy season communication became almost impossible. A traveler, in 1828, complains of the roads: "All that can be said about them is, that they are as bad as they possibly can bepassable only for mules, and that, often, at the risk of one's life." ${ }^{3}$

The very high cost of transportation, which resulted from poor facilities, made it impossible for Mexico to develop trade outside the immediate zone of production in any but highly valuable articles, nor could foreign trade fare better. Long before the actual building of railroads it was evident to the more farseeing among the population that the stagnation from which the country suffered was due, to a large degree, to poor transportation facilities.

The first railroad built emphasized this need of the country at large, although the rates charged were so high that it continued to cost more to take a ton of goods from Vera Cruz to Mexico than from London to Vera Cruz. As soon as the railway reached out toward the capital, it began to disturb the old economic conditions far beyond its immediate neighborhood, illustrating the benefits that were to come from rail facilities and the great disadvantages that would fall upon cities left off

${ }^{2}$ Karl Sapper, Wirtschaftsgeographie von Mexico, 1908, p. 31 et seq and Joseph Nimmo Jr., Commerce between the United States and Mexico ... Washington, 1884, p. 20 et seq.

${ }^{3}$ Mexican Company; extracts from the report of Justus Ludwig von Uslar, relative to the Negociacion of Yavesia in the State of Oaxaca, January 6, 1828. 
the new routes. Tampico, for example, had been an important source of supply in the old days for a number of the states of the central plateau but, after the railroad from Vera Cruz to Mexico was established, the trade of the table lands began to be drained off southward instead of to the Gulf port to the east.

As to railroad policy, public opinion began to divide into two camps. In one were those who saw that the new day for Mexico meant investment of large amounts of foreign capital and the extension of the American railway net southward to include the Mexican system. In the other were the conservatives, who shrank from contact with the aggressive world around them for fear there might come with the new associations influences that would threaten the independence of the disorganized fatherland.

During the period before the Diaz régime the conflict between those who wanted the building of railroads and those who did not was largely theoretical, for railroad enterprise, with the exception of the line to Vera Cruz, was practically unknown. The poverty and disorder, which had so long characterized the country, made capital still reluctant to invest. ${ }^{4}$ The reëstablishment of what appeared to be a lasting peace gradually dispelled this fear and capitalists in the United States began to look more favorably on Mexican railway projects, but they showed a disposition not to invest their money "unless the protection of the Government of the United States, by some treaty stipulation or other convention,

${ }^{4}$ Papers Relating to the Foreign Relations of the United States, 1878 , p. 549. 
goes with it." At the same time the less sanguine Mexicans stiffened their opposition to railway enterprise and especially American railway enterprise. Many illustrations of these prejudices might be cited. A contract was arranged by the Mexican executive with the International Railroad Company of Texas in 1873, which provided that all the capital, shareholders, employees, and all persons connected with the company should be considered Mexicans in all that related to the enterprise within the republic and could not maintain claims as foreigners "even when alleging denial of justice." The charters of the pre-Diaz period had similar clauses. But though companies could be formed on such a basis, getting the money to put through the project under such conditions was found impossible. Capital was wary. As the American Minister reported, American contractors would not forswear their nationality for the sake of building a railroad in foreign lands, nor renounce the right to appeal for protection to their own government, a right recognized by international law.

Whenever railroads were under discussion in the Mexican Congress, the more timid showed themselves

'Ibid., p. 639. A contract of November 12, 1877, similar to the one cited above, was presented to the Congress in which, in addition to forswearing their rights as Americans, the builders were required to build the branch to the American border northward from a point in Mexico instead of southward from the Rio Grande. The project was defeated because it was too favorable to the foreigner. The conditions as to nationality above cited, in their revival in recent legislation, have caused widespread protest. They are, in fact, no new thing. They were already a familiar feature of railway contracts early in the Diaz régime. Ibid., 1879, pp. 776-80. 
convinced that the border was in great danger of advancing southward with the rail heads. There was a firmly rooted suspicion that the United States had an ulterior interest in every move taken by its people involving Mexico. It was a part of the general fear of the foreigner, of the belief that the only safety for the weak lay in playing off the strong against each other. Railway building in itself, it was recognized, was desirable but railways to the northern border would destroy the natural defenses of the republic. Although the bills introduced into Congress included provisions to the effect that the property of the railroads could never be made the subject of international claims, the fear of closer neighborhood with the United States was so great that the projects met repeated defeat. ${ }^{6}$

Contrary to popular opinion in the United States even Diaz did not see, from the beginning, the importance of railway development for his country. At least he was not above playing upon the popular prejudice against the foreigner to the disadvantage of his political enemies. In his "plan" dated at Palo Blanco, March 21, 1876, he charges the Lerdo government with having delivered the country over to an English company by the grant of a concession to the Vera Cruz railroad. He declared that it had been agreed to transfer the English debt to the United States "which is equivalent to selling the country to the neighboring nation." Such projects "rob us of our future and sell us to foreigners." "

6 The Sonora railroad project defeated. Ibid., 1880-1, p. 719.

${ }^{7}$ An extract from this proclamation, which is a good example of revolutionary rhetoric, is found in ibid., 1879, p. 780 . 


\section{MEXICO AND ITS RECONSTRUCTION}

In fact, during his first years of control in Mexican affairs, Diaz was as captious with the rights of foreigners as have been some of his successors. In the first issue of the Government Gazette, published after he secured control of the capital, he declared null railway contracts made by his predecessor. He later forfeited railway charters, changed schedules of railway tariffs in violation of contract, and confiscated construction work already done. The following quotation from a speech in the National Chamber of Deputies, on May 22, 1878, illustrates the sort of anti-foreign opinions that supported such acts. The executive had made a contract for a road from Mexico to the Pacific and to the frontier of the United States in Texas or New Mexico. A speaker opposing the project declared: ${ }^{8}$

It is very poor policy . . . to establish within our country a powerful American company . . . we are going to establish within our territory an American influence. ... Border nations are natural enemies . . . without referring to history, but considering only contemporaneous acts, who despoiled France ... ? The bordering nation, Germany. Who is invading Turkey at the present time? The bordering nation, Russia. -What war is there between Spain and Russia? None. It is a natural law of history that border countries are enemies. . . .

Hence, sir, the United States . . . are naturally our enemy. .... And will it be prudent in this case to place the enemy within our house?

There is also another law in history; nations of the North necessarily invade the nations of the South. ... Unfortu-

${ }^{8}$ Hon. Alfred Chavero, in ibid., 1878, p. 551. See also another remarkable document in ibid., 1879, p. 828 et seq. 
nately, we do not need to recur to foreign histories; a rich part of our territory has become the prey of the United States. ... Hence, we should always fear the United States.

We have seen that a hundred leagues of railroad from here to Vera Cruz have given such influence to the English company that many times this very influence has been sufficient to decide the votes of the chamber, and shall we be so insane as to consent to the establishment of an American company which will embrace the whole country . . . all our sections and all our roads?

Would you exchange your beautiful and poor liberty of the present for the rich subjection which the railroad could give you? Go and propose to the lion of the desert to exchange his cave of rocks for a golden cage, and the lion of the desert will reply to you with a roar of liberty.

The fears as to the consequences of railway development were especially strong in reference to the northwestern territory of the republic, but the circumstances there could be turned in favor of a liberal policy quite as effectively as they could be used in opposition. A representative from that region argued that only by the development of the border states could they be saved to Mexico. Their growth would create an equilibrium with the United States, otherwise "we exist in such a manner as causes us to represent in the eyes of the other nations the rôle of a sickly, decrepit man, by the side of a hale, robust one. . . ." If development is not brought about in these statesi,"exasperation will drive them nearer our neighbors than anything alleged by those who fear that the influence ... of the American union may produce another mutilation of our territory. . . . It is very dangerous to see just beyond a conventional 


\section{MEXICO AND I'TS RECONSTRUCTION}

line prosperity and wealth, and on this side destitution and poverty. ...."

With the cooling off of at least officially expressed anti-foreign feeling and the establishment of order the foreigners who were interested in railway development gradually weakened in their feeling that the right of appeal to the home government must be recognized before they could undertake projects in Mexico. At the same time the Mexican Congress came to realize that the advantage of rail connections with the United States overbalanced the attendant dangers.

When Diaz assumed control of the government in 1876 there were 666 kilometers of railroad in the country-the line from Mexico to Vera Cruz-and proposed American connections, as is indicated above, were unpopular. This prejudice was largely removed in the first term of the dictator and in September, 1880, the Mexican Central Railroad and the Mexican National Railroad received permission to build from Mexico City lines to the Rio Grande border. Thereafter the building of Mexican railroads was carried on practically without interruption to the end of the Diaz régime. At its close in 1910 the 666 kilometers of railway running at its beginning had increased to 24,559 kilometers. There were then two lines instead of one connecting the capital with Vera Cruz. There were two transcontinental lines and two connecting the capital with the American border.

It is hard to overestimate the benefits conferred on Mexico by the broader policy of railway development

${ }^{9}$ Antonio Morano, Senator from Sonora in ibid., p. 831. 
that had its beginning in the early '80s. Along each stretch of line there grew up a productive area contributing to national wealth and to the strength and stability of the government, which had been far sighted enough to abandon the conservatism and prejudice of the former generation. Agriculture flourished as never before. Mining interests could market products that formerly had been valueless and for industries conditions were created that made possible local production in many lines, in more than household industries for the first time in history. ${ }^{10}$

The advantages, which the early years indicated, were continued and increased throughout the Diaz régime. Heavy freight could now be carried long distances, ore, lumber, sisal, all the articles of large bulk that enter into Mexican domestic and foreign commerce came to have value where they had none before. The railroads were one of the important links in the chain of circumstances that made the Mexico of the Diaz régime a possibility and seemed to guarantee that the republic had entered at last on a period of peaceful development that would not be easily interrupted. In international relations, too, the railroads had had a beneficent influence. The improved communications had turned a large part of Mexican commerce in a north and south direction. The United States had come closer to the republic, not only in time but in economic interest and in understanding.

${ }^{10}$ An excellent description of the effect of the railways upon Mexican development is found in Bernard Moses, Railway Revolution in :Mexico, 1905. See also Luis Pombo, Mexico: 1876-1892, Mexico, 1893, p. 52 et seq. 


\section{MEXICO AND ITS RECONSTRUCTION}

The ill will of the pre-railway period had largely disappeared, due in no small degree to the iron bonds that drew the two republics together. Especially in the closing years of the Diaz régime friendship had replaced distrust. The new day, which had come with the railroads and had been hastened by their construction, seemed to promise continued peace and prosperity for the republic both in its internal and in its foreign relations.

Although the railroads built before the end of the Diaz régime did bring a revolution in the conditions of traffic, they never solved the transportation problem. Large areas were still far from the rail lines and the old disadvantages of isolation still applied to them-often almost to as great an extent as before the railway era. There was always need of still further railway extension to open up the resources of the country.

Moreover, the disadvantages of the railless regions were accentuated greatly by the lack of good wagon roads.

Spain did not create, in her colonies, either well kept trunk lines nor supplemental highways of good character. In fact, even to the present day the home country lacks them. The former colonies have not created them for themselves since their winning of independence. One of the most important problems that will confront the Mexican government of the reconstruction era will be to extend the transportation facilities of the country in a way that will effectively unlock the resources now held embargoed by their lack.

Unfortunately the developments during the revolu- 
tionary years have not been such that will let the governments of the new Mexico begin where the Diaz régime left off in the construction of means of communication. Transportation routes, one of the first objects of care among modern nations in times of peace, are often among the first to be neglected in time of war. Roads do not become impassable with temporary neglect and railroads can run for a time with a small expenditure on repairs. In the area of military operations they are carefully protected or ruthlessly destroyed according to what the contestants think will contribute to their advantage. The temptation for both parties in a civil war is to let them deteriorate where they do not directly contribute to the fortunes of war.

The history of the 16,000 miles of railroads during the decade of revolution in Mexico has been tragic for their owners and fantastic for those whom they served. The instrument that did so much to bring peace and order was made a means by which first one side and then the other was able to carry on operations against its opponents more successfully than otherwise would have been possible. Only illustrations of the sorts of conditions that arose can here be given.

The physical ruin of the roads is all but complete. A series of governments, each fighting with back to the wall, has had no resources with which to keep up repairs. The income of the roads themselves has suffered diminution because of falling traffic and the violent fluctuations of the value of the paper money in which services were paid. The extent of the demoralization of the service is illustrated by the report of the National Rail- 


\section{MEXICO AND ITS RECONSTRUCTION}

ways of Mexico for 1916. ${ }^{11}$ The president reported no receipts from operation and a debit of 21,870,213,02 silver pesos for the year. The debit since the beginning of the revolution was almost 80,000,000 silver pesos. The nominal reported receipts were extraordinarily high in some periods but they did not appear to reach the treasury and, even if they had done so, their real value was but a fraction of their face, since they were in the Vera Cruz issue, which was worth 14 or 15 cents gold in January, 1915, but later fell rapidly to two cents and and then so low that it refused to circulate.

The rolling stock gradually disappeared from active use. The military chiefs confiscated it to military uses in transporting troops or as spoils of war, if it was captured while in possession of the enemy. The various socalled generals used the cars "as barracks and permanent dwellings for the soldiers and their families, and frequently for freight transportation within their jurisdiction for personal profit."

The railway employees, or at least those in authority. over divisions that were still in operation, seized the opportunity to create a system of graft seldom, if ever, equaled. It is true they are hardly to be blamed, for they could not live on the salaries the government paid to them in its own depreciated currency. Government officials in the railway administration shared the illegitimate returns directly or indirectly. The few cars available were eagerly sought by those whom rashness or

${ }^{11}$ Eighth Annual Report of the National Railways of Mexico, June 30, 1916, pp. 16-19, signed by Alberto J. Pani, who was president of the Railway and Minister of Railways at the same time. 
necessity forced to keep shipping goods under the prevailing uncertain conditions. No cars were forthcoming without liberal gratifications. In short, the revolution brought to the railways, in the regions it affected, first neglect and then anarchy.

Unfortunately for Mexico it must face, during the reconstruction period, the necessity of repairing the system of communication, which was thus destroyed. It is a disadvantage not measured by the damages that must be paid to those whose property disappeared or depreciated in value because of the use to which it was put during the conflict. Perhaps even more serious will be the losses that the people of Mexico as a whole must suffer through the inefficient service, which is all that can be furnished during the period when the roads will operate with poor and insufficient equipment. To destroy the railroad system of a country is not only to destroy the property it directly represents but also to reduce the value of the property of the country that the railroad serves. ${ }^{12}$

The recent governments in Mexico have recognized that the reëstablishment of communications is one of the first essentials for the economic revival of the country. The roadbed of the railroads suffered less during the revolution than the rolling stock. Bridges burned or blown up in the area of military operations first received the attention of the government but many have

12 Descriptions of the conditions on the railways brought about by the revolution, and of the plans of the Carranza government for improving the railway net are found in Railway Age, vol. 66, pp. $1531-4$ and 1549 . 


\section{MEXICO AND ITS RECONSTRUCTION}

even now been given only temporary repair. Mexican railroads lost about 10,000 freight cars and 400 locomotives during the revolution. Large numbers of freight cars were burned or wrecked and, in order to encourage getting those that could be repaired back into use at an early date, a plan was adopted through which any concern might reconstruct cars at its own expense, receiving in return the right to control them for its own use for a period usually of one to two years. ${ }^{13}$ American railroad lines allowed their freight cars to go into Mexico when bonds were given for their safe return. On October 15, 1920, the Pullman Company began letting its cars enter the country without this restriction. ${ }^{14}$ An arrangement made with the American Railway Association on January 1, 1920, allowed a large number of freight cars to be taken across the border and the Mexican government announced its desire to set aside $\$ 30$,000,000 Mexican to purchase additional rolling stock. ${ }^{15}$ On June 1, 1921, President Obregón appointed a personal representative to introduce improvements in the handling of traffic. ${ }^{16}$ Though congestion of freight at the ports still continued to be a serious problem, at least the first steps had been undertaken toward reëstablishment of that standard of communications reached at the end of the Diaz régime.

${ }^{13}$ W. H. Moseley Jr., "Mexico To-day" (pamphlet), New York, November, 1920.

${ }^{14}$ Railway Age, January 7, 1921, p. 113.

${ }^{15}$ Commerce Reports, February 18, 1921, p. 993.

${ }^{16}$ Commerce Reports, June 21, 1921, p. 1650. 


\section{CHAPTER XIV}

\section{INDUSTRY AND INTERNAL COMMERCE}

INTERNAL industrial development was practically non-existent in Mexico before the Spanish conquest and remained negligible throughout the colonial period. Indian industry for the supply of local wants continued throughout the country districts. The civilization was static both socially and geographically. In the towns, it is true, some articles of European manufacture were introduced but they were only those that could bear high carrying costs. They did not displace native manufactures because they reached only those of European blood, nor did their high price, as a rule, give rise to local manufacture.

The typical Mexican manufactured products that found their way into European trade, if the simple process by which they were produced can be dignified by the name of manufacture, were the precious metals, cochineal, indigo, and sugar. Because of the exclusion of foreigners, the commercial and industrial development, so far as it was not in the hands of the native races, was monopolized by Spaniards.

One of the first industries established-a reflection of the development the Spaniards emphasized in the country-was the coining of silver, which was begun at the Mexico mint, established in 1537. Toward the end of the colonial period a beginning of textile manufacture 


\section{MEXICO AND ITS RECONSTRUCTION}

did occur, the chief centers of which were Querétaro, San Miguel el Grande, Puebla, and the Intendanz Guadalajara. The latter two were credited with a production of cotton goods valued at over $3,000,000$ pesos ${ }^{1}$ in 1802. The industry was in the hands of small spinners and weavers. Querétaro produced both cotton and woolen goods. There were a few silk weaving establishments, this industry having been introduced by a Frenchman. ${ }^{2}$ A few printing establishments and glass and fayence factories built up a small trade.

The developments in industry in the outside world during the nineteenth century had a greater effect on Mexico than in the preceding period. Some Mexican industries were killed. Cochineal and indigo lost their place in trade. New lines appeared, lines that had a more direct connection with the modern conditions, which, little by little, were coming to affect the life of the republic. The first quarter-century following independence was so disturbed that no important development of industry occurred and no statistics are available giving a survey of the efforts made in small establishments.

Some factors of Mexican life favored industrial development in the last half of the nineteenth century. In the industries in which native labor could be used to advantage the low labor cost encouraged investment. The low exchange rate of silver raised the price of imported articles and thus favored local enterprise. Fur-

${ }^{1}$ Karl Sapper. Wirtschaftsgeographie von Mexico, 1908, p. 25.

${ }^{2}$ Maurice de Perigny, Les Etats Unis du Mexique, Paris, 1912, p. 101, and Sapper, op. cit., pp. 25-30. 
ther, the government sought to help industry as it did agriculture by creating artificial advantages for local enterprise, not only in a protective tariff but, after 1893, by special exemptions. In that year the executive was empowered to give special privileges to those setting up new industries in the country if their investment amounted to 250,000 pesos. These privileges might include freedom from direct federal taxes and freedom from customs taxes on the machinery and other materials of construction necessary for setting up the establishment. ${ }^{3}$ The states adopted a similar policy, to attract industry to their own territories.

The textile industry is the best known of Mexican manufacturing developments and the one in which the Mexican population has had its best opportunity to display its abilities. Cotton weaving is naturally its most important branch. The first cotton mill is said to have been set up as early as 1829. The credit for giving the industry its first genuine impulse, however, appears to belong to Esteban Antuñano, who set up his first establishment in Puebla in $\mathbf{1 8 3 3 .}$

Advance sufficient to justify extensive export has not been made, in fact, there is still, in normal times, an important import trade in textiles. The grades of goods chiefly produced are medium priced cottons, such as meet a wide demand among the common people. Fine cotton goods, however, are woven and in their making the native has shown himself of decided capacity.

In this industry, as in all others established in Mexico,

${ }^{3}$ Maurice de Perigny, op. cit., p. 100. 


\section{MEXICO AND ITS RECONSTRUCTION}

the period of rapid development began with the early '90s. At the outbreak of the revolution there were 324 factories reported as manufacturing cotton and wool textiles. The most important of the cotton mills were those of the Compañía Industrial de Orizaba, operating the famous Rio Blanco mill, founded in 1892, and others at Cocolapan, San Lorenzo, and Cerritos; that of the Compañía Industrial Veracruzana, founded in 1898, known as the Santa Rosa mill, at Orizaba; that of the Compañía Industrial de Atlixco, near Atlixco, and those of the Compañía Industrial de San Antonio Abad, in San Antonio Abad, Miraflores, and Colemena. The capital in these companies is predominantly French.

The most important woolen mill was the Fabrica de Tejidos de Lana de San Idelfonso in Tlalnepantla. The most important jute factories are the British owned Santa Gertrudis in Orizaba, and the Aurora in Cuatitlan in the State of Mexico. ${ }^{4}$

Factories producing sugar, candy, and chocolate numbered over 2,196 in 1912. Most of them were small. Hidalgo led the list in number of establishments with over a fifth of the total. The other states that ranked high were in order Jalisco, Nuevo Leon, Vera Cruz, Oaxaca, and Puebla. ${ }^{5}$

Though Mexico has a comparatively high production of sugar, export has not yet come to be important. A very important by-product of the sugar factories of Mexico is rum, which is also chiefly manufactured for

Erich Gunther, Handbuch von Mexico, Leipzig, 1912, p. 181'.

'Statistics in Erich Gunther, op cit., p. 184. 
the local market. After the sugar industry the production of brandy is the most widespread industry of Mexico. There were 1,417 factories reported before the revolution, depending chiefly upon sugar cane and corn as raw materials. About 40 breweries were in operation and they were, with few exceptions, in German hands. ${ }^{6}$

Tobacco manufacture has become one of the widespread industries of Mexico. There were 482 factories in operation at the outbreak of the revolution. The greatest number were found in the cities of the central plateau and in the Gulf coast states of Vera Cruz and Tamaulipas. The states of the southeast and most of those of the northern belt were poorly represented. ${ }^{7}$

Electrical power development is limited in Mexico because of the torrential character of most of the rivers, the uneven flow of which makes the power actually, available very irregular. Nevertheless, there are a number of power plants of importance, among which are that on the Rio Blanco owned by S. Pearson and Son, a British interest controlling also an electric light and power company in Vera Cruz, which operates water rights on the Rio Antiguo and the Rio Octopan. The Atoyac Irrigation Company is a hydraulic electric company with rights on the Atoyac River, which uses the spent waters for irrigation. At the outbreak of the revolution it was controlled by a Puebla company, which also had concessions on the Portezuelo and the

'Ibid., p. 185.

${ }^{7}$ Statistics of the location of factories are published in ibid., p. 183. 


\section{MEXICO AND ITS RECONSTRUCTION}

Rio Blanco. The power rights at Nexaca Falls are owned by the Mexican Light and Power Company, a British interest.

The development of industry has been hindered in Mexico, as it is in many other countries, by lack of a good supply of coal. What industrial development has occurred has had to depend largely on the great forests of the country for fuel. As those lying within easy reach of the railroads have been exhausted, the price of wood has naturally risen and efforts to obtain substitutes have been increased. Imported coal continues to be expensive. Some advance has been made in the utilization of water power, especially in the textile industries but the country's rivers are not of sufficiently steady flow to make reliance on that resource satisfactory. Fortunately, the development of the oil regions along the Gulf coast has now placed Mexico in a favorable position, so far as the fuel requirements of her industries are concerned, a factor in which the republic is now as favored as it was formerly unfortunate.

Indirectly, the progress of the local industrial development is reflected in the foreign trade returns of the two decades preceding the revolution. Imports of manufactures ready for consumption increased but little. The total value, for example, of such articles as cloth, chemicals, liquors, paper, vehicles, arms, and explosives was $\$ \mathbf{1 7 , 1 5 7 , 0 0 0}$ in 1896 . In 1906 it had risen to $\$ 25,982,000$, but, while the first figure was 40 per cent of the total, the latter was but 24 per cent. In the same 
period, machinery imports doubled, animal products increased 170 per cent, vegetable products 133 per cent, and mineral products-including fuel and metals-more than fourfold. Apparently the growing industry of Mexico was already enabling it to supply itself with the cheaper articles of local consumption and at the same time increasing the demands for food, machinery, and raw materials. ${ }^{9}$

Turning from manufacture to internal trade, we find that in the country at large during the colonial period commerce went on in much the same channels as before the coming of the white man. The Indians manufactured their simple home-industry wares for local consumption and, to a lesser degree, for the trade of the city, where they were sold for the articles that each community did not produce for itself. The white population in the cities gradually came to act as middlemen for the local, as well as for the foreign trade. ${ }^{10}$ Supplementing the regular local markets there were occasional fairs, notably at Jalapa, held chiefly for the goods coming from Europe and, at various times, at Acapulco, San Blas, and Mexico for the goods brought back from the Far East in the irregular trade of the Manila galleons.

Foreign merchants made their way but slowly into Mexico, even after the winning of the independence of the republic. By 1850 there were a number of French retail houses established in the larger towns of Mexico, especially in the dry goods business. The rest of the

${ }^{9}$ Commercial America in 190\%, Washington, 1909, p. 48.

${ }^{10}$ Karl Sapper, op cit., 1908, p. 30. 


\section{MEXICO AND ITS RECONSTRUCTION}

jobbing and retail business in that line was still controlled by Spaniards and Mexicans. There were three French banking and commercial houses, and two wholesale houses. Eight German, and three English wholesale houses also had established themselves. ${ }^{11}$

In the interior towns, even after the middle of the century, there were still few foreign houses. Strangers were suspected, especially if they had money and the insecurity of the country made even capital that was venturous enough to go to the larger centers unwilling to take the risks of carrying stocks elsewhere.

It was not until after 1870 that marked increase of activity in internal trade began to be shown. At that time the British and Germans had in their hands all the wholesale trade and the manufacture of wool and cotton in which the French were later to play a prominent part. A curious development has occurred in this line in Mexico. After the opening of the country, at the end of the Spanish régime, the British came to control it, but were forced to share it with the Germans. The latter practically replaced the British but were in turn themselves displaced by the French. The Germans and British also controlled the sale of silks, iron and steel, and jewelry. The Spaniards had the wholesale and retail trade in liquors and groceries, lines in which they have continued to figure prominently. ${ }^{12}$

${ }^{11}$ M. P. Arnaud, L'Emigration et le commerce francais au Mexique, Paris, 1902, p. 54. This work and Maurice de Perigny, op. cit., give excellent accounts of the French influence on the economic development of Mexico.

${ }^{12}$ Arnaud, op. cit., p. 65, and House of Representatives, Docu- 
Foreigners have continued to be a prominent factor in the commercial life of the republic and each group has shown a tendency to control certain lines of business. At the end of the Diaz régime the French continued to be prominent in the dry goods and clothing trade and had "practically monopolized" the sale of notions. Better class bakeries, fine jewelry stores, tailoring establishments and a part of the grocery stores were owned by them. The employees of these establishments were also largely French. ${ }^{13}$ Americans came to control the trade in machinery and machinery supplies. Germans were prominent in the hardware business-much more prominent in disposing of the goods than the proportion of German manufactured hardware imported indicates. British commerce showed less tendency to confine itself to special lines.

It is easy to overemphasize the degree to which industry and modern commercial methods have found their way into Mexico and this is often done by those who know only the Mexico of the large towns and of the strips of territory that are within range of the whistle of the railway locomotive. Outside of these areas the Mexico of to-day retains, to a degree hard for the American or European to realize, the conditions of a generation ago and in many districts almost the conditions of the time of the conquest. ${ }^{14}$

\section{A prominent characteristic of Mexican commerce}

ment 145, part 5, 58th Congress, 3d Session, "International Bureau of American Republics," Mexico, p. 68.

${ }_{13}$ M. P. Arnaud, op cit.

14 Karl Sapper, op. cit., p. 37. 


\section{MEXICO AND ITS RECONSTRUCTION}

continues to be the degree to which the capital is its center, in spite of the facilities introduced by the railroads for its decentralization. Mexico City, the metropolis of the country, by a wide margin is the center of Mexican commerce to an even greater degree than Paris is the center of French trade. The railroads that converge at the capital have helped to continue the habit of the provincial commercial interests to look upon it as the source of supply. In it are the chief banks and from it much of the industrial activity is directed. ${ }^{15}$

The harm done to industry in Mexico during the years of the revolution is much smaller than it would have been had the country had greater development of local manufactures. Agriculture, the chief industry of the republic, suffered severely. In some states, like Vera Cruz, the farming population flocked into the towns. As a result the sugar crop of the state fell from $\mathbf{1 7 0 , 0 0 0}$ tons in 1911 to 40,000 tons in 1917-18. The Cordoba coffee crop dropped off in the same period from $50,000,000$ pounds to $20,000,000$. In other areas the people, though they stayed on the land, did not plant crops which they felt no assurance they would be allowed to harvest and market. The cattle industry of the northern states steadily declined. That in Chihuahua was reported in $\mathbf{1 9 1 8}$ to be only about five per cent as important as before the revolution. In other states legislation for dividing up the large estates threatened to make stock raising impossible.

The effect of the revolution on some of the manufac-

${ }^{26}$ House of Representatives, op. cit., p. 
turing industries is hard to estimate. Tobacco manufacture appears to have flourished. The textile mills, though they were hampered by the secondary results of the revolution: sabotage, strikes, high taxes, and impractical labor legislation, continued to operate at a satisfactory rate during at least a portion of the revolutionary period.

Mining, taken as a whole, did not prosper. The northern states were one of the favorite battlegrounds of the revolutionists and only properties near the railroads or large towns could be operated with any degree of security. 'The Chihuahua smelters were closed down for the two years ending April, 1918, and other mining operations were at a low ebb.

The worst industrial conditions seem to have been passed by 1918. From that time on the agricultural population has been less disturbed by bandits and the farmers were reported in 1920 to have gone back to work except in remote districts and certain sections of Puebla, Chihuahua, and Durango.

The rapid rise in the value of silver in the latter part of 1919 encouraged extending that branch of mining and the output of other metal and mineral products was increased under the stimulus of the business boom following the declaration of peace in Europe. ${ }^{16}$

The effect of the revolution on mercantile operations was to induce the sacrifice of stocks in regions threatened by disturbance. Those supplies that were left when the roving military forces came were often con-

${ }^{16}$ Supplement to Commerce Reports, June 21, 1921. 


\section{MEXICO AND ITS RECONSTRUCTION}

fiscated outright or paid for by warrants issued by the commanding officers. Once the stocks were gone their former owners replaced them, if at all, only by buying for minimum current requirements. The paper money issues also demoralized mercantile accounts and the stories of the experiences of some of those who found themselves forced to accept worthless paper for goods they had purchased on a gold basis are among the most extraordinary which the revolution produced.

In mercantile as in industrial activities a gradual improvement from 1918 on has occurred with the re-adoption of the gold standard and establishment of comparative order by governments whose control is accepted or acquiesced in by the war-weary population. 


\section{CHAPTER XV}

THE FOREIGN ÇOMMERCE OF MEXICO:

BEFORE DIAZ

Commerce is the lifeblood of governments. Without it public revenues and public works are impossible. Through all of Mexico's history as a colony and through much of her independent existence this truism was not appreciated. Through practically the entire colonial period the mother country sought to stifle the economic development of the great region to which it had given its name, or at least to confine it to such narrow, prescribed channels that no commerce could develop proportionate to the great latent possibilities of the territory.

The first half-century of independence brought little improvement, for though the policy of throwing the country open to world commerce was adopted, its domestic troubles and the disasters of its foreign relations shut off the development that might have occurred. Foreign capital was unwilling to trust itself in the midst of the revolutionary storms, and domestic enterprise did not have a chance to show its abilities.

A consideration of the unfortunate commercial conditions, which prevailed before the Diaz régime, is necessary for an understanding of the present-day economic problems that confront the republic. They indicate the difficulties that faced the new government in its efforts 


\section{MEXICO AND ITS RECONSTRUCTION}

to shake itself free from the past, and they show the origin of many of the limitations under which commerce continues even to the present day.

Like other colonizing nations of the age of discovery, Spain sought to keep for herself all the advantages of her new possessions. To do so, she shut out all but Spaniards, and even trade with Spain was allowed only under strict regulation. Seville and Cadiz were made the only ports of entry in the home country, and only through Vera Cruz could the commerce pass into Mexico. This system of control lasted, with few exceptions, for about two and a half centuries. There were violations by large numbers of smugglers, but in theory there was but one recognized door through which the regular trade of Mexico could pass. ${ }^{1}$ Boats first went out singly, but later, for mutual protection against pirates and to avoid frauds in the revenue, they were required to sail in fleets. Not until the so-called ordinance of free commerce issued by Carlos III on October 12, 1778, did the old system nominally come to an end.

Concerning the character and value of this early trade there are no satisfactory data. For the first 50 years little more than an average of one boat a year went to Mexico, taking a cargo largely made up of supplies and armament and returning with native products about the character of which there is little available information. For the two centuries preceding 1778 the records are almost equally unsatisfactory. There appears to have been a steady rise in the tonnage of the fleets sent in the

${ }^{1}$ Miguel Lerdo de Tejada, Comercio esterior de Mexico desde la conquista hasta hoy, Mexico, 1853, p. 8. 
last 70 years, which probably reflects a rise in the value of the commerce. Precious metal shipments from Mexico increased. There are lists of the goods carried by some of the later fleets. The last fleet under the old monopoly system, which arrived in $\mathbf{1 7 7 6}$ and returned in 1778, carried to Mexico a cargo in which the chief elements were quicksilver, iron, and iron manufactures. The exports from Mexico in this year were-first of all - silver, to the amount of over $1,680,000$ pesos on the king's account and 9,800,000 pesos for individuals. There were sent 232 tons of copper and some gold, tin, sulphur, red ochre, indigo, wood, cotton, wool, and hides. Two and a half centuries of Spanish rule had developed in Mexico only one important resource-metals-among which silver, which has been even up to our own day the connotation of Mexican commerce, easily held first rank. Other raw materials played an unimportant part, and local manufactures then, as in all the previous history of the country, were conspicuous by their absence.

The legal position of Mexican commerce in the closing years of the colonial period was much more favorable than before. To be sure, free commerce did not mean what the words mean to us, but the trade was opened during these years to more than a dozen cities of Spain; Vera Cruz ceased to be the only port of entry; and the restrictions on coastwise trade were relaxed. Trade, however, followed much in the old channels. Local society had not been leavened by the conquerors. The coastwise trade did not develop; trade with the world at large was not yet free; and Vera Cruz, that "unwholesome town" with its "disagreeable anchorage among 


\section{MEXICO AND ITS RECONSTRUCTION}

shallows" continued to be the port at which all but a small part of the foreign commerce entered and from which the exports of chief value were shipped. ${ }^{2}$

One other branch of Mexican trade in the colonial era deserves mention-the commerce with Asia, which the mother country always looked upon with jealousy but which it felt it necessary to allow in spite of the fact that it drained off part of the highly valued silver production of Mexico and brought back from the East textiles that competed with her own manufactures. This was the trade through the galleons, which sailed usually from Acapulco for the assistance of the unprosperous colony in the Philippines. The Spanish merchants always looked upon this commerce as an unavoidable evil at best. In 1593 a royal decree confined the trade to two ships a year, in which not more than 500,000 duros of silver could be sent in return for the Chinese goods which they brought to Mexico. Except as to the number of ships, the government's regulations of this trade were always observed in the breach. The officials in Manila and in Mexico lent themselves to all sorts of evasions. Shipments of as much as 4,000,000 pesos in a single year are reported to have gone to the Philippines.

After the middle of the eighteenth century the restric-

${ }^{2}$ For discussions of the commerce of this period see: Alexandre do Humboldt, Political Essay on the Kingdom of Nere Spain, London, 1814, 2 d ed., vol. 1, p. cxvii, and vol. 3, p. 492; Chappe D'Auteroch, Voyage to California, London, 1778, pp. 20-1; Henry Ker, Travels Through the Western Interior of the United States from. the Year 1803 up to the Year 1816; with a particular description of a great part of Mexico, or New Spain, Elizabethtown, N. J., 1816, pp. 222-224; Miguel Lerdo de Tejada, op. cit., passim. 
tions on trade were gradually relaxed but the commerce between Mexico and the Far East was never prosperous in the colonial era, nor did it cover even as wide a range of articles as the trade with the home country. Silver went westward, also some iron, cochineal, cocoa, wine, oil, and wool. Eastward the cargo was chiefly of silks. Smaller quantities of spices, china, and other Oriental wares were imported. ${ }^{3}$

Almost a half-century passed between the ordinance of free commerce of $\mathbf{1 7 7 8}$ and the establishment of the republic, but the actual development of commerce under the new conditions was disappointing. Statistics are incomplete and the totals were probably greater than the official returns show, but they were far from satisfactory. In the latter portion of the period, 1796 to 1820 , the average announced value of imports was 10,000,000 pesos, that of the exports about $11,000,000$. The continuance of the policy of shutting out foreigners, the troubles of the government at home, international conflicts, and an illiberal policy in Mexico itself prevented the growth that might have occurred.

The main characteristics of foreign commerce were unchanged. Trade went by Vera Cruz to Acapulco. It continued to go in fleets. The exports were silver plus some raw materials; the imports were manufac-

${ }^{3}$ Chester Lloyd Jones, "Spanish Administration of Philippine Commerce," Proceedings of the American Political Science Association, vol. 3, 1906, pp. 180-193. The intercolonial trade from Mexico to South America was negligible. Shipments of cocoa were made in later years from Caracas to Mexico and some traffic developed with Cuba. 
tured goods. Foreign trade did not touch the Mexican people in their daily lives. There was nothing to indicate that the trade of Mexico with the more advanced countries would soon assume the character of their trade with each other. Even in amount the trade was disappointing and showed no tendency to increase; the true economic development of Mexico was still unbegun.

The statistical record of Mexican commerce for the first half-century of independence is highly fragmentary, due partly to a failure to realize the importance of such a record and partly to the disturbed conditions in the life of the republic. Plans for publications, bravely undertaken, were seldom continued for more than a few years. For the period 1828-53, a quarter of a century, no publication of a commercial balance of the trade of the republic occurred.

What the trade developments were is further obscured by the shifting tariff system and by the fact that the customs house accounts were often neglected completely when revolutionary forces got control of the ports. There were, moreover, special rates collected in certain ports of entry and special remissions of taxes to persons and places. Within the country also the internal customs houses collecting the octroi taxes, historically known as alcabalas, were a burden on commerce, the effect of which it is impossible to estimate.

The new republican government threw open more ports than the colonial administration and allowed the general entry of foreign owned ships. On the other hand, the general tariff policy, if that phrase can be used in connection with anything so capricious and illogical 
as the early Mexican tariffs, was as distinctly illiberal as the navigation policy was progressive. Revenue had to be raised and the import dues were the main reliance. Protection of industries existing and to be born was also alleged to be a motive back of the customs charges. As a result the customs taxes were high, so high in many cases as to prohibit honest importation, lessen the income to the public treasury and make smuggling a highly profitable and not disgraceful business. Some lines of goods, and for a time the list showed a tendency to grow, could not be imported at all. Of these there were 245 items in the tariff of August 14, 1843. In spite of the "protection" thus afforded, local manufacture did not grow. The only industry which did take root was cotton manufacture, which began in a small way under the stimulus of a special subvention included in the tariff laws of April 6 and October 16, 1830.

A careful estimate of the average annual import trade for the first quarter-century of independence puts the figure at 20,000,000 pesos. ${ }^{4}$ The chief countries contributing were Great Britain, which apparently sent over half of the total; the United States, which sent onefifth; and France, which sent about one-eighth. Textiles were the most important item from Europe. The United States trade was more varied. It suffered a sharp decline in the latter years of the period due to the political difficulties which finally resulted in war.

Import trade in the second quarter-century of independence was still far from prosperous. Revolutions,

4 Ibid., p. 52 et seq. 


\section{MEXICO AND ITS RECONSTRUCTION}

frequently changing tariffs, and the uncertainty of the rates that any shipment might have to pay continued to make importation into Mexico a gambling business. The disturbing influence of the Free Zone established on the northern border was added to the already complex trade problems after 1858, and the French intervention made conditions, if possible, still worse. Only with the coming of the Diaz government were fairly stable rates of customs established. Then also fairly reliable customs reports appeared, the first of which was published in 1878.

Textiles were still the most important item imported. They made up, at that date, 54 per cent of the total. Hardware, machinery, and metal goods formed 20 per cent, and groceries and liquors 16. Great Britain still led in textiles, which were the great bulk of her exports to Mexico. Local manufacture, however, under the high protection and unusual prices obtainable during the American Civil War, had established itself and, in certain lines widely used by the common people, was driving the foreign goods out of the market. Metal manufactures still came almost exclusively from abroad. Railway iron and steel came from England, engines and cars from the United States. The latter, even at this early time, took the lead in the shipment of agricultural machinery, and Germany led in hardware. The groceries trade had already found the channels in which it has to a large degree remained. Flour, breadstuffs, and canned provisions, at the end of the pre-Diaz period, came chiefly from the United States, wines and spirits from France, and olives and olive oil from Spain. 
The quarter-century before the Diaz régime saw a lively international contest for Mexican imports. In 1853 it appears that, of the total value of some 26,000,000 pesos, Great Britain furnished almost 50 per cent and France and the United States about 17 per cent each. The German states then contributed about 7 per cent. Thereafter there were various ups and downs in which the United States definitely forged ahead of France in the middle '70s and in 1878 passed ahead of Great Britain, never again to be overtaken. France, meanwhile, fell to the position of a minor competitor. For her and for Great Britain the advance of the railways, then being planned in the north, meant a steadily growing handicap in competition for Mexican trade.

Turning now to the export trade during the first halfcentury of Mexican independence, we find statistics as unsatisfactory as in the case of imports. They are, in fact, so unsatisfactory that the best method of arriving at the character and value of the goods that were sent abroad is to study the returns of imports from Mexico as published by her chief customers: Great Britain, France, and the United States. The shipments in the first quarter-century of independence were unimportant, except for precious metals and cochineal. In the second a better showing was made. A greater variety of articles made their appearance-earnest of what would occur once the country was opened up to foreign commerce.

Between 1850 and 1878 a sharp international rivalry went on between Great Britain, the United States, and France for the control of both of the branches into which 
Mexican exports naturally fall. In buying merchandise from Mexico the countries ranked in the order named at the beginning. Under the stimulus of the high prices obtainable during the American Civil War the trade of the first two was greatly increased, and Great Britain shot far ahead of her competitors. At the end of the conflict trade values fell again and in $\mathbf{1 8 6 7}$ the three were in the same relative positions as a decade before. Two years later, however, the United States passed Great Britain, taking a lead which was to be greatly accentuated by the opening of the railway era. By 1881 the United States held a share almost as great as that of the other two nations combined.

In the bullion and specie trade the United States took the lead earlier for reasons largely connected with the monetary policy of the country. In fact, by 1857 the bullion purchases of Great Britain and France were almost negligible. During the Civil War period the American share declined rapidly and the monetary legislation of the various countries in the years following made the course of silver shipments highly unstable. Beginning with 1876, shipments to the United States regúlarly exceeded those to either France or Great Britain.5

Compared to the total import and export trade at the end of the first quarter-century of Mexican independence, the showing in the early '70s was satisfactory. Imports were somewhat less than $30,000,000$ pesos in

- Exports of metals, like imports, doubtless would have shown a much better total but for the unfortunate taxing system-one that discouraged honest enterprise and encouraged smuggling. 
1872-3. The exports to the three chief customers averaged about $\$ 27,000,000$ for the five years ending 1876 . $^{\circ}$ But, though the relative gain was good, the actual increases in both lines were unsatisfactory. Fortunately fibers, coffee, hides and skins, and valuable woods were increasing in importance in the export figures foreshadowing a time when the products saleable abroad would have greater variety.

It is hard for us to realize now the handicaps under which commerce was carried on in Mexico in the preDiaz period. Goods could be transported only at great expense. Only those that combined high value with small bulk could stand the cost of carriage for any great distance and the most important of even these were so heavily burdened with transportation costs and internal taxes that production for more than local use was profitable only under the most favorable natural circumstances.

The commercial situation was like that of the pioneers who settled beyond the Alleghanies in the early years of the United States and found that the cheapest way for them to market their corn was to change it into whiskey so that transportation charges might be as low as possible. The conditions were similar except that there existed in Mexico no navigable rivers that might serve as natural highways by which to reach the sea and the outside world. Even after the middle of the century litters carried by mules or men were used for passenger travel between Vera Cruz and interior points and re-

${ }^{6}$ Calculated from the import returns reported for the United States, Great Britain, and France. 


\section{MEXICO AND ITS RECONSTRUCTION}

liable diligences were still rare. In 1878, long after the resources of her northern neighbor had been tapped, there was still no railway net and the local highways were seldom worthy of the name. Transportation by pack mules, or at best by wagons drawn by mules or oxen, was slow and costly but the only means available.

Those who had dealings requiring the shipment of money long distances, and this included, of course, all engaged in foreign trade, found the transfer of credits a great handicap. Exchanges by draft were not generally understood or used. A fair average of the expense for interior remittances from Mexico City cited in 1878 was eight to ten per cent to Chihuahua, five or six to Morelia, and four or five to Oaxaca. If money went abroad, the charge was still greater. In 1868 the taxes and cost of transportation of silver sent from Mexico City to the Bank of England were 25 per cent of the value of the shipments.

Conditions were rapidly developing to the northward which were sure to bring great impetus to Mexican trade, and at least partially remove its disadvantages. The United States was beginning to come into the market for raw products and to sell her manufactures. Regular steamship communications, discontinued during the Civil War, were reëstablished in $\mathbf{1 8 6 8}$ and the railroads at the close of the pre-Diaz régime were breaking their way through the southwest toward the northern frontier of Mexico. To assure a great increase in the import and export trade of Mexico only the establishment of order and a better system of communications within the country were needed. 


\section{CHAPTER XVI}

THE FOREIGN COMMERCE OF MEXICO: THE DIAZ REGIME AND AFTER

From the '70s until 1892 the statistics of Mexican imports are only less fragmentary than those in the years before the Diaz régime. Frequent tariff changes disturbed what would have been the course of development and the tariff classifications are not such as make easy the analysis of the trade as a reflection of changing national economic demands. This latter difficulty, in fact, continues up to the present time.

The textile trade, which was the characteristic feature of Mexican imports in the preceding periods, continued to be the most important factor though less important in comparison with the total imports, and less important when compared to the total consumption, for a local industry was developing, which, through high tariff protection, was gaining ground steadily.

In 1872-3, 58 per cent of the total invoice value of imports was made up of textiles, a position maintained as late as 1884. Then conditions changed rapidly. In 1889-90 the value imported had risen but the percentage of the total had fallen to 22 per cent. Local competition was gaining strength and the demands of Mexico on the world's markets were becoming diversified and greater. Textile imports, therefore, took a less prominent place. The decline in their relative importance in 


\section{MEXICO AND ITS RECONSTRUCTION}

the period from the early '90s to 1912-13 was steady. The value doubled in this period but the proportion of the total sank to 13 per cent.

To a very considerable degree the passing of the importance of these goods reflects the decline of the British leadership in Mexican imports. For generations textiles have been one of the characteristic features of British trade and at one time they were not only the chief item of Mexican imports but practically an undisputed British field. By 1912-13 they were neither. Mexican and foreign competition was pressing British manufacturers hard. The cotton thread and handkerchiefs imported were still practically all British. A large share of the lace trade and of that in coarse cottons had been lost. In the better trade in piece-goods British mills still made about seven-eighths of the imports. Wool yarn imports came from Germany, light wool goods chiefly from France; only in the heavier woolens was the wool trade distinctively British. Serious inroads were made on a number of less important branches.

It is impossible to analyze satisfactorily the developments in Mexican imports other than textiles. In the first part of the Diaz régime the classifications are often according to the rate of tariff paid and in the later years on physical characteristics rather than utility. In general, the government followed the policy of favoring the introduction of materials that did not compete with Mexican industry and which, through encouragement of induistry, would give a stimulus to the development of the republic. It frequently freed such goods from tariff charges. The tariff of 1872-3 allowed but 12 per 
cent of the imports to enter free of duty. That of 1884-5 gave similar treatment to 22.9 per cent of the imports.

, On the other hand, Mexico sought to have foodstuffs produced within the country. Imports were loaded with increasing tariff rates, with the result that between 1872-3 and 1888-9 the proportion of foodstuff items in the total, and their actual value fell off sharply. The economic advance, which was then under way, however, was so rapid that in the latter part of the Diaz régime foodstuff demands were so great that imports increased in spite of the high tariffs and greater local production.

After 1892 the chief tariff classifications are animal substances, vegetable substances, minerals, textiles, and their manufactures, and machinery and apparatus. It is not possible to trace such groups as foodstuffs through these figures satisfactorily, so comparisons must follow the Mexican classifications. They show a remarkable expansion of Mexican imports reflecting the rapid economic exploitation of the country. Between 1893-4 and 1912-13 imports of animal substances increased four fold in value. Leather goods and preserved meats, lard and wool imports, all indicative of a higher standard of life than the Mexican had formerly enjoyed and of the demand created by the presence and example of the foreigner, constituted more than one-half of the total in the class.

Imports of vegetable substances increased between 1893-4 and 1912-13 over two and a half fold. The growth was general in a large number of lines, the most important of which was cotton. The local cotton pro- 


\section{MEXICO AND ITS RECONSTRUCTION}

'duction has not been great enough to supply the demand of the Mexican mills and increasing supplies have had to be drawn from the United States.

From the Mexican point of view the two tariff classes, minerals, and machinery and apparatus with the allied class, chemical products, are the ones that show the most interesting development in the national import trade. In the old days quicksliver went into Mexico and metal products went out. Except for quicksilver, imports of mining products were negligible. Machinery was conspicuous in Mexican trade by its unimportance, so also were chemical products. But the Diaz régime brought these unimportant factors to the forefront. They displaced textiles as the outstanding feature of Mexican imports. They were important for the development of the country because they represented the goods drawn from abroad for its economic regeneration. The first two classes together increased almost fourfold between 1893-4 and 1912-13. Chemical and pharmaceutical imports increased six fold. These were figures that reflected the purchases abroad of the iron and steel, tin, copper, coal, coke, electrical goods, agricultural and other machinery, and railway equipment, which were so important a factor in creating the new Mexico.

One of the most interesting features of a country's foreign commerce is brought out by the study of the source of supply of its imports and the destination of its exports. ${ }^{2}$ Since before the beginning of the Diaz

1 The comparisons that follow are not exact because transhipment trade is not satisfactorily shown in Mexican statistics. 
régime only four nations have figured prominently in Mexican import trade. Great Britain, the United States, Germany, and France furnished over 90 per cent of the total in 1872-3, 92 per cent in 1892-3, 89.5 per cent in 1902-3, and 87.3 per cent in 1912-13. After the beginning of the World War the United States came to have a practical monopoly of Mexican foreign trade.

Among these nations there has been a long contest for control of the commerce. In 1872-3 Great Britain was in the lead, with about 35 per cent of the total. It would be hard, of course, to maintain such a share as the general exports from the nearby United States developed. This was particularly true with the establishment of railroad connections across the northern border.

At the beginning of the next 20-year period the shipments to Great Britain had sunk to slightly over 13 per cent, which continued to be about her share in 1902-3 and 1912-13. British, French, and German competition for a share in Mexican trade was keen throughout the Diaz régime. France controlled 16 per cent of the total in 1872-3. She had the advantage of dealing in lines that, to a large extent, were composed of distinctively national products, but her trade in many branches was not easily expandable because the public that consumed her products in Mexico was not large nor of rapidly increasing numbers. Germany, on the other hand, soon began to bid for the trade in iron goods and textiles and to come into intimate competition with Great Britain and later with the United States.

By 1892-3 Great Britain had fallen from first place and was clearly outclassed by the United States. She 


\section{MEXICO AND ITS RECONSTRUCTION}

still led France, though by a narrow margin only. Germany and France together then had a trade 40 per cent greater than the British. Relatively Great Britain was losing even in comparison with her European competitors. At the opening of the next 10-year period French and German trade had again gained; it was 60 per cent greater than that of Great Britain. Meanwhile Germany had passed France in 1901, not again to be overtaken, and a close contest for second place in Mexican imports was occurring between her and the former leader. In four years in the decade following 1902-3 German trade was greater than British and in many lines was offering sharp competition to that of the United States.

The rise of German trade was the most striking feature of Mexican imports from European countries. In 1872-3 the total credited to the German states was only $3,890,496$ gold pesos. Twenty years later it had fallen to 3,322,700. Then began a steady rise. In the decade ending 1902-3 it almost tripled and in 1902-3 to 1912-13 increased another 30 per cent. Had peace continued it does not seem unlikely that Germany might have established herself in firm control of second place in Mexican imports.

First place, meanwhile, had definitely fallen to the United States. Before the railway era in 1872-3 onefourth of the imports came from the United States, in spite of the lack of rail routes between the two countries. Twenty years later over 60 per cent did so. In 1902-3 54 per cent of the imports came from the United States; in 1907 almost 63 per cent; and in 1912-13, 51 per cent. 
Railroads, propinquity, and the rapidly growing manufacturing industries of the northern republic assured it the greater part of Mexican import trade. These advantages were temporarily increased by the World War, which made the United States almost the exclusive market in which Mexico purchased for import. Parallel with that of imports there was in process, meanwhile, a rapid growth in export trade and a contest for its control. The shipments out of Mexico naturally fall into two great classes-the mining products and all others. Historically the characteristic exports of Mexico are the precious metals. As late as 1872-3 they were 81 per cent of the total. But though they continued to rise in yield they fell in relative importance. The total metals export was valued at 20,294,321 pesos in 1874-5. Twenty years later the precious metals sent abroad were worth $52,535,854$ pesos, 30 years later $93,885,526$ pesos, and in $1912-13,130,885,339$ pesos. But in the same period commodities exports had risen in even greater proportion. In 1874-5 they had been worth 7,024,467 pesos; 20 years later they were worth $38,319,099$ pesos; 30 years later in 1904-5, 114,634,924 pesos. At this latter date commodities exports had already passed the precious metals exports in value, and in 1912-13 they rose further to $169,520,212$ pesos' worth. In other words, while precious metals exports had increased 650 per cent, those of commodities rose 2,300 per cent. This meant that Mexico was less distinctively a mining country than at any time in her history. Her mining, too, was becoming less characteristically devoted to the precious metals, especially silver. 


\section{MEXICO AND ITS RECONSTRUCTION}

There is no reason to believe that Mexico will cease to be one of the world's great sources of silver supply, but in recent decades other mining products have assumed an increasing importance. The exploitation of the base metals has had an extraordinary development and the oil resources have been developed so rapidly that the total yield of the country is now determined by the conditions under which the product may be marketed, not by the amount the wells are capable of producing.

The growth of this export is a twentieth century development. There was a small sale of local oil products for about a decade preceding the beginning of the export trade. The total production reported was 75,375 barrels in 1903 and 3,634,080 in 1910. The first cargo of crude oil left Tampico May 20, 1911, by an American steamer. Thereafter the growth in production was rapid and all but a small part went directly into the export trade. In 1911 a total of 12,552,798 barrels was produced. By 1913 an increase of over 100 per cent was recorded, the total being $25,696,291$ barrels. During the war the production continued to rise and could have been increased still further had it been necessary, for the potential yield of the wells had now outrun the ability to market the product. The total for 1917 was $55,292,770 ;^{2}$ for 1918 , $53,919,863$; for $1919,87,072,955$; and for $1920,156,062,-$ 707 barrels.

2 The statistics of production up to and including 1917 are as reported by the Petroleum Bureau, Department of Industry and Labor, Mexico City, as quoted in John D. Northrup, Petroleum in 1917, Washington, 1919, p. 875. The figures for subsequent years are as reported in the New York Times July 2, 1921, quoting 
In spite of the importance of this growth it must not be overlooked that the most significant, and for the republic the most important, developments in her export trade in the last generation have been in other lines. No nation whose prosperity depends on a few products is ever on a sound economic basis. Exhaustion of resources, bad growing seasons, and bad market conditions always have possibilities of national disaster for such a state. A nation is secure only when by the variety of its products it can escape the difficulties that may at any time attend the production of a few of them. Mexico at the beginning of the Diaz régime was in the condition first mentioned. At its end she had progressed far toward the second standard.

To be sure manufactures continue to have but a weak development but agricultural and forest products have become diversified in the last generation and the economic foundation upon which the Mexican national life rests has undoubtedly been broadened thereby. Moreover, the growth of the list of exports represents not only a stabilizing element in national commerce but a development toward a standard that favors a democratic government.

Though Mexico still has many cases that seem to indicate the contrary, agriculture is the small man's business. It is the occupation which, in the development of nations,

W. C. Teagle, President of the Standard Oil Company of New Jersey. Rafael Alcerraca, chief of the Petroleum Department of the Mexican government, estimates 1920 production at $163,000,000$ barrels, Nere York Times, June 18, 1921. 


\section{MEXICO AND I'TS RECONSTRUCTION}

has given the first great impulse toward respect for the rights of one's fellowman, and toward a desire for order. It is the occupation in which individual initiative and industry first received impetus. Mexico will find it of the highest importance to foster the growth of her classes who live independently upon the land, if the republic is to become what it never has been, a truly democratic government.

The agricultural exports reflect but imperfectly the degree to which this development has already taken place in Mexico, for the reason that many of the lines in which harvests have been greatly increased enter export but slightly and because even some of agricultural products that are exported, such as henequen, are not typically the yield of small holdings. Nevertheless there can be no question that the diversification of agricultural products and of the export of them is indicative of a change in the national life of fundamental importance.

From still another point of view this development is interesting. It reflects, to a degree, a development of hot lands heretofore disliked and neglected by both native and foreigner. Henequen, coffee, rubber, vanilla, and chicle, among the vegetable exports, are names that suggest tropical climates.

The growth of the agricultural exports of Mexico can only be sketched here. Up to the present henequen fiber, or sisal, has come, almost entirely, from Yucatan. It is the material from which the greater part of the binder twine used in the United States is made and it finds almost its exclusive market in that country. The 
'export in 1877-8 was valued at 1,078,076 pesos, that for 1912-13 was worth $31,133,755$ pesos. $^{3}$

The value of exported sisal increased remarkably during the World War but, like the figures of international trade in many other lines, this reflected a development of exceptional character and not one that can be expected to continue in times of peace. With supplies of Manila hemp cut to a minimum by the war, Yucatan producers met an exceptional market for their product. In addition the local government set up a system of market control that forced the prices still higher. As a result sisal fiber, which sold at an average of $\$ .055$ United States gold per pound in the five years before the war, rapidly rose in nominal value reaching a peak of $\$ .2125$ United States gold per pound at one time during the conflict. Such returns are now a thing of the past. In 1921 sisal was back to its prewar price level. The market was depressed by large stocks, and a production more than sufficient for the decreased peace time demand. However, the advance that had been made in pre-war times will be maintained. It is beyond doubt that Mexico's

${ }^{3}$ Tables of the exports of henequen are found in Luis Pombo, Mexico: 1876-1892, Mexico, 1893; Matias Romero, Mexico and the United States, New York, 1898; Statistical abstract for the principal and other foreign countries, etc. . . . London, 1907 and 1912; Reports from Her Majesty's diplomatic and consular agents abroad on subjects of commercial and general interest, Commercial No. 36 (1883), Part VII, Report by Mr. Lionel E. G. Carden on the trade and commerce of Mexico, 1883 ; Anuario de estadistica fiscal, Mexico, 1913 and 1914; and in the Boletin de estadistica fiscal, año fiscal 1910-11, Mexico, 1912. The statistics quoted for other agricultural products in the following paragraphs are from these authorities. 
sisal production will contribute increasingly to her foreign trade. Other vegetable fibers, especially ixtle and broom root, have also been exported in increasing quantities.

Coffee culture was introduced into Mexico from the West Indies. Two areas, one on the Atlantic with the cities Orizaba and Cordova as centers, and the other on the Guatemalan border, have proven especially suited to this crop. The United States has always been the chief buyer. Before 1870 exports were negligible. By 1878 they had risen to a value of 1,242,041 pesos and in 1912-13 to 11,263,701 pesos. Raw tobacco, of which a value of 132,971 pesos was exported in 1872-3, was sent abroad to the amount of 1,002,611 pesos in 1912-13. Chick peas, garbanzos, were apparently first exported in $1882-3$, when a value of 28,855 pesos was shipped. In 1912-13 garbanzos worth 4,930,362 pesos left the country. Rubber exports began to be important in 1896-7. They rose rapidly to a value of 21,187,770 pesos in 1910-11, the highest value they ever reached. In the same year guayule was exported to a value of $11,797,910$ pesos Mexican currency. Important increases are also to be noted in cabinet and dyewoods, vanilla, chicle, cattle, and hides and skins. The diversification of Mexican exports is illustrated by a comparison of the articles exported to the amount of $1,000,000$ pesos at various periods. Besides the precious metals, there were in 1877-8 only three such articles, in 1882-3 only four, in 1891-2 only five. Then came the period of rapid development. There were 12 articles besides mineral products in this class in 1902-3 and in 1912-13 there were 14 . 


\section{RECENT FOREIGN COMMERCE 211}

The enumeration of the chief items of Mexican export is evidence of the degree to which the republic continues to be, so far as its export trade is concerned, a raw product country. In some lines manufactures have been developed to satisfy a large part of the local market, but even in 1912-13 they constituted only 1.1 per cent of the total exports. The chief factors in exports of manufactures were cheap hats and manufactured tobacco.

The changes in the international shares of Mexican trade already noted in connection with imports were even more marked in the export trade. Precious metals shipments in the middle '80s were about evenly taken by Great Britain and the United States, then the latter took the lead and held it steadily thereafter. Its share rose to about three-fourths of the total in the middle '90s and it stood at a little above that point in 1912-13. Since the outbreak of the World War exports to countries other than the United States have been only a negligible percentage of the total.

In the commodity market in general Mexico has never sold to any one on as good terms as to the United States. That country led even before the Diaz régime, its next competitor, Great Britain, even then, taking only about a value onc-fourth as great. As early as 1878, 60 per cent of the commodity exports went to the United States. By the '90s over three-fourths of the total took that direction. In 1912-13, 77.2 per cent went to the northern neighbor of Mexico-about the same per cent of the total as in the case of the precious metals exports.

In spite of Mexican distrust and in the face of the failure of the average American to understand the Mex- 


\section{MEXICO AND I'TS RECONSTRUCTION}

ican point of view, the trade relations between the two great republics of the North American continent have grown increasingly intimate and important. The mutual economic interests are so interrelated and fundamental that they have proven and will continue to prove so powerful that no political propaganda can counteract them. There is no true geographical boundary between the two countries, and communications between them by both land and sea are well developed, better developed indeed than between many regions within Mexico itself. The economic development of the two is highly contrasted but supplemental. The United States is the best market for what Mexico has to sell and the easiest source of supply for what she wishes to buy. In 1912-13 Mexico bought almost four times as much from the United States as from any other country and more than from all other countries combined. In 1912-13 Mexico sold to the United States over seven times as much as to any other country and almost four times as much as to the five nations next in importance in Mexican export trade. The percentages have risen still higher during and since the World War but are not indicative of a condition that will continue in normal times. These latter, however, will not fail to demonstrate the essential commercial unity of interest of the two republics.

That there should be friendly relations between two states bound so closely together by their material interests seems axiomatic. That the international exchange between the two countries is to their mutual advantage is not likely to be disputed; nor is it subject to 


\section{RECENT FOREIGN COMMERCE 213}

question that this trade is of very much greater importance to Mexico than to the United States. In Mexico's total trade this commercial interchange with the United States is not only the dominant factor but the greater part of its total foreign commerce, a position which the same trade is far from occupying in the case of the United States.

Those who wish a resumption of orderly development in Mexico cannot overlook the part that foreign commerce played in the old régime in placing the country on its feet, giving work to the people, and resources to the government to carry out the progressive measures it supported. They should not forget to what degree that commerce was made possible through the United States market and the enterprise of Americans who came to the republic with their capital.

The trade of Mexico in the early '70s presents but a sorry contrast to that in the opening decade of the twentieth century. Imports were stationary at about 30,000,000 pesos. Exports were worth about the same amount. Railroads were practically unknown. Only the most valuable products could be imported or exported. Good crops rotted through inability to take them to market and bad crops in the less accessible regions meant famine. Property and life were insecure.

At the end of the period, in 1912-13, imports were reported at 192,292,461 pesos, exports at 300,405,552. Railways reached the more important producing areas. Goods formerly unmarketable went to parts of the country where they were needed and went abroad by thousands and tens of thousands of tons. Property was 


\section{MEXICO AND ITS RECONSTRUCTION}

protected and, at least comparatively, personal liberty was assured.

The change, of course, was not due to any one new element introduced into the national life. It was the product of a complex of influences, which, whatever its shortcomings, was bringing about in Mexico a transformation of the old into something better. Among these influences, on the whole beneficent, that of foreign commerce was constant and important. It operated both as cause and effect.

The growing imports gave greater resources through customs taxes to the government. They stimulated the people to new wants, and brought in the machinery and raw materials for new industries and for the expansion of old ones. They made possible better protection of life and property and encouraged the investment of capital, both foreign and national, in lines that would have been impractical before.

As exports expanded new areas were brought under exploitation, not only for their mineral resources but for the vegetable and animal products. The exports, in turn, made increase of imports possible and gave an aspiration toward a standard of life that was impossible before. Few influences, indeed, worked more clearly for the broadening of the national life of Mexico than did the development of her foreign commerce. Fewseemed to carry, to a greater degree, the assurance that the industrial development of the country, which it helped to make possible, would gradually bring about a social as well as an economic reconstruction and assure in the republic the continuance, by less arbitrary means, 
of the orderly development that had been maintained during the reign of President Diaz.

That commerce would suffer during the widespread disorders brought by the revolution was to be expected. The actual effects of the local conflict are obscured in its later years by the developments of the World War, which, by giving a great stimulus to certain lines of international trade, distorted the trade values and upset the normal conditions in a number of important lines of Mexican production, notably silver, sisal, and petroleum. As a result, the uncertainty as to the amount of the totals of the trade brought by the early years of the war has been succeeded by uncertainty as to what the figures mean, now that some published by the Mexican government again become available.

The most contradictory conclusions are arrived at by different persons. If, for example, the reports of crop production are considered as an indication of commercial conditions, the picture presented even for 1918, the last year for which figures are available, is very gloomy.

These returns seem to show a very serious cutting down of the production of the staples upon which the people of the country depend. The crop decline has affected international trade less than might be expected, since those who use imported goods are not the people at large and the chief cereals do not enter foreign commerce in large amounts.

If the returns of international trade and of customs collections be interpreted as those in control of the government allege they should be, Mexico must be admitted 


\section{PRODUCTION OF CERTAIN CROPS IN MEXICo}

\begin{tabular}{|c|c|c|}
\hline & $\begin{array}{l}\text { Average yearly } \\
\text { production, } \\
\text { 1906-1910 } \\
\text { (Kilos) }\end{array}$ & $\begin{array}{c}\text { Production } \\
\text { for } \\
1918 \\
\text { (Kilos) }\end{array}$ \\
\hline Rice $\ldots \ldots \ldots \ldots \ldots$ & $31,033,637$ & $12,520,300$ \\
\hline Barley $\ldots . . \ldots \ldots \ldots \ldots$ & $445,396,850$ & $17,924,260$ \\
\hline 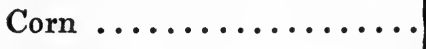 & $3,219,624,240$ & $1,171,750,893$ \\
\hline 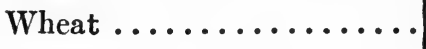 & $306,782,890$ & $187,892,586$ \\
\hline 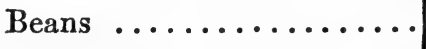 & $163,397,200$ & $107,465,720$ \\
\hline Chick-peas ........... & $60,535,620$ & $69,303,650$ \\
\hline 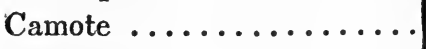 & $22,936,645$ & 72,000 \\
\hline 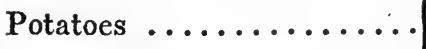 & $20,069,642$ & 327,795 \\
\hline Green Chile ........... & $56,251,716$ & $\ldots \ldots \ldots$ \\
\hline Dry Chile $\ldots \ldots \ldots \ldots \ldots$ & $9,809,031$ & 691,454 \\
\hline Sugar Cane ........... & $2,257,144,953$ & $3,077,4: 00$ \\
\hline 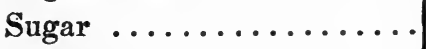 & $105,887,340$ & $16,600,000$ \\
\hline 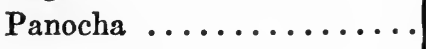 & $74,546,666$ & $10,308,968$ \\
\hline Honey $\ldots . . . . . . .$. & $85,226,502$ & ...... \\
\hline Peanuts $\ldots \ldots \ldots \ldots \ldots$ & $6,628,980$ & $\ldots \ldots \ldots$ \\
\hline Cotton $\ldots \ldots \ldots \ldots \ldots$ & $40,506,796$ & $79,292,700$ \\
\hline Henequen ............ & $84,840,287$ & $158,066,682$ \\
\hline 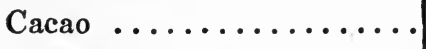 & $2,906,021$ & $2,500,000$ \\
\hline Coffee ............... & $35,788,007$ & $47,582,540$ \\
\hline 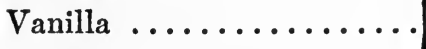 & 188,005 & $\ldots \ldots \ldots$ \\
\hline Tobacco $\ldots . . . . . . .$. & $14,395,321$ & $12,608,337$ \\
\hline
\end{tabular}

to be about to enter a period of prosperity in its foreign trade such as she has never known.

4 Commerce Reports, September 27, 1919.

$\checkmark$ The statistics in the following paragraphs are taken from a summary of the message of President Carranza published in the Statist, London, November 22, 1919, p. 1121, and Commerce Reports, December 3, 1918; June 18, 1919; and October 17, 1919, quoting reports of the Mexican government. The Presidential ad- 
The exports for the year 1918 were valued at 367 ,305,451 , compared to $300,405,552$ pesos, the record for 1912-13. Imports totaled 164,470,035 pesos, still much less than in 1910-11, when they totaled 206,000,000 pesos. Detailed returns for 1918 and subsequent years have not been published. The war had greatly emphasized Mexico's dependence on the United States in her foreign trade. Approximately 95 per cent of all exports in 1918 went thither and about 90 per cent of the imports were purchased there.

President Carranza, reviewing the state of the country in his message to the Congress in the autumn of 1919, pointed out that the customs receipts for 1918 were the greatest in history, the total for 1918 being over $\mathbf{3 7 , 7 0 0 , 0 0 0}$ pesos, or six million greater than the record of the best years of the old régime. The striking contrasts between the reports as to production in the country on the one hand and the figures of foreign trade and the income derived therefrom on the other, are due, in large degree, to circumstances quite independent of any action taken by the local government. The fact is that the apparent prosperity of Mexican foreign trade in 1918 and 1919 was due not to what the revolutionary government had or had not done but to the abnormal conditions created by the war in Europe.

The export trade of 1918 was announced as of a value of $367,305,451$ pesos, as compared to $300,405,522$ pesos in 1912-13; while that of 1919 reached 424,462,471

dress of C. Adolfo de la Huerta published in Diario Oficial, September 2, 1920, gives the value of Mexican exports in 1919 as 424,462,471 pesos and that of imports as $265,178,706$ pesos. 


\section{MEXICO AND ITS RECONSTRUCTION}

pesos. ${ }^{6}$ This is a marked gain and might indicate an encouraging general increase of commodity shipments. A detailed comparison to determine the degree to which such a development did or did not occur is not possible with the statistics at hand. It seems clear from an analysis of certain items, concerning which information is available, that the result is to be attributed more to the general high level of prices in the world's markets and the unusual circumstances surrounding certain lines of production than to a general revival of commerce in the republic. In the case of silver, which is regularly one of the most important of Mexican exports, the actual production was not unusual. The yield of Mexican silver mining from 1907 to 1914 remained practically stable at an average of about 70,000,000 troy ounces per year. The next two years saw a sharp decline, only $22,838,400$ ounces being produced in 1916. Thereafter the totals rose, reaching 62,517,000 ounces in 1918 and about $75,000,000$ ounces in 1919. Meanwhile, however, the value of silver per ounce had very greatly increased. It averaged \$.60835 United States currency in 1912 and $\$ .57791$ in 1913 but rose to $\$ .96772$ in 1918 and to $\$ 1.11122$ in 1919. Had silver remained at near its average pre-war level, therefore, or had it been at the levels it has since reached, the value of that portion of Mexican export trade would have shown a decline as compared to 1912-13.

In the case of petroleum a remarkable increase of yield has occurred, but without the coöperation or en-

${ }^{6}$ Presidential address of C. Adolfo de la Huerta, Diario Oficial, September 2, 1920, p. 25 et seq. 


\section{RECENT FOREIGN COMMERCE 219}

couragement of the revolutionary governments. The total production in 1912 was 14,051,643 barrels; in 1918 it was $63,828,327$ barrels; and in 1919, 87,072,955 barrels. These items alone, due to the increased value per unit in the one case and to the increased yield in the other, brought about by conditions over which the Mexican government had no control, explain the greater part of the nominal increase in the value of Mexican export trade in 1918 and 1919 as compared with 1912.

The larger customs income also is deceptive since it reflects not so much an increased volume of general trade as higher rates on a number of lines of imports. In fact, as noted above, the actual value of imports was considerably less in 1918 than in 1910-11. The customs returns, moreover, include the yield from the new export taxes on petroleum shipments.

Hawever welcome the greater money values of exports and of the customs income is, they are not to be taken, therefore, as a reflection of a reëstablished capacity for production in the country. The degree to which the latter has come about can be better judged by the way in which Mexico will be able to weather the deflation of the values of all her export commodities, which has set in after the war boom. For this period no statistics have yet been published. 


\section{CHAPTER XVII}

\section{COLONIZATION}

IT is hard for Americans, who have seen their country welcome immigration of European stocks and prosper from so doing, to realize that other states, even American states, have not uniformly followed the same policy.

In Mexico an illiberal exclusive policy was followed before its existence as an independent state. Spain first kept foreigners out because she wished to keep all the benefits of local resources for her own people and to keep all the people under the unquestioned dominance of Spanish institutions. Later to these motives was added the fear that to abandon that policy would mean to open the way for foreign aggression.

As early as 1602 the attention of the civil and ecclesiastical authorities was called to "the evils resulting from foreigners going to the Indies, to reside in the ports and other places, it being found that our Catholic faith is not secure, and it being important to see that no errors may be sown among the Indians and other ignorant persons." The officers were commanded to "aid in cleansing the land of these people, and that they cause them to be expelled from the Indies." 1

Twelve years later even trade with the non-Spanish world was prohibited to the colonies "under a penalty of

${ }^{1}$ Law 9, Title 27, Book 9, Recopilación de Indias, Philip III, 1602. 
death, and confiscation of the property of those who-violate this our law." 2

The suspicion of foreigners continued a part of Spanish policy to the end of the colonial period. Mexican distrust was studiously turned against the then weak United States. From time to time the governors "were admonished to keep a vigilant eye upon the restless sons of the Northern Republic." When New Spain threw off the yoke of the mother country it might have been expected that this policy would be reversed, that the foreigner would be welcomed and that a rapprochement between the young republics of North America would occur. To some degree this did happen. Discriminatory legislation was repealed and the laws above cited were suspended by decree of October $7,1823 .^{3}$

There can scarcely be said to have been an established policy on international affairs in Mexico in the years following the winning of independence, for domestic problems kept her statesmen so fully occupied. Toward foreigners there was a clearer policy than on most lines. Those in power realized more clearly, it appears, than have some of their successors that the foreigner was essential to the development of a strong Mexico. Persons of European stocks were to be encouraged to settle in the republic. It was believed that it would be best for the central government to deliver over to the states the encouragement of immigration since each would be anx-

${ }^{2}$ Law 7, Title 27, Book 9, Recopilación de Indias, Philip III, 1614.

${ }^{3}$ This reference and the two above are taken from Papers Relating to Foreign Relations of the United States, 1888, vol. 2, p. 1166. 


\section{MEXICO AND ITS RECONSTRUCTION}

ious to increase its population. A decree to that end was issued in 1824. The only limitation was that lands 20 leagues from the frontier or 10 leagues from the coast could not be colonized by foreigners except with the permission of the central government.

By 1831 at least two colonization projects had been launched. The legislature of the state of Vera Cruz gave the valley of the Goazacualco (Coatzacoalcos) River to a French company which sent out various expeditions. These enterprises met disaster. The colonists gradually drifted away to regions better developed. or back to the home land.

The other venture was the only one of the early colonization contracts that was successful. It was from the Mexican point of view also the most disastrous, for it ultimately brought with it the dismemberment of the republic. 'This was the colony of "Texas, in the State of Coahuila and Texas." Under the colonization contracts of April 11, 1823, 6,391 families had entered from the northeast by January 2, 1830. Others "entered without contract and without the knowledge of the authorities," establishing themselves "at their will, especially near the frontier." Already the northern colony was displaying some features that were the cause of anxiety, for in some of the settlements "in view of the lack of adequate legislation, the customs and laws of the country from which the colonists have come have been observed." No advance "worthy of notice" had at this time been made "in the territories of Mexico and California." "

4 Lucas Alaman, Memoria de relaciones, January 5, 1831, republished in Vicente E. Manero, Documentos interesantes sobre coloni- 
Later, Mexico attempted to redress the balance by inviting "all persons of the Republic to colonize in Texas, offering to transport them at the expense of the Treasury," to give them tools, and to maintain them for the first year, but the proposal did not attract popular support. $^{5}$

General colonization schemes continued to hold the attention of the government in spite of the fear of what was going on in the north. Extraordinary inducements were offered to encourage settlement and guarantees of protection for person and property were freely given. The general policy adopted was well outlined in the decree of March 11, 1842, issued by that adventurer-

zacion, Mexico, 1878, pp. 16-18, and Manuel Siliceo, First Memorial of the Minister of Fomento, February 16, 1857, p. 43 et seq. See also the Memoria of Jose Maria Lafragua to the Congress, December 14, 1846, in the same volume, p. 22.

${ }^{5}$ Manuel Siliceo, op .cit., p. 43 et seq., republished in part in Manero, op cit. This report explains in detail the failure of various colonization schemes.

'In Papers Relating to Foreign Relations of the United States, 1888, vol. 2, p. 1167 et seq., are cited the following decrees granting protection to foreigners quoted from Legislación Mexicana, o sea coleccion completa de las leyes, decretos y circulares que se han expedido desde la consumación de la independencia. This volume contains the laws in force at the time of publication and, therefore, does not show all the legislation which had been passed on the subject.

Decree of October 7, 1823, suspending discriminations of the laws of the Indies against foreigners.

Law of Colonization of August 18, 1824.

Decree of September 6, 1833, for protection of persons and property of foreigners.

Decree of March 11, 1842, declared still in force January 30, 


\section{MEXICO AND ITS RECONSTRUCTION}

statesman, President Santa Ana. The law declares that "after mature reflection and a most careful examination

1854, allowing acquisition of land and exemption from military service.

Decree of October, 1842, absence of a foreign owner does not cancel title.

Decree of June 16, 1856, vessels bringing immigrants for colonies in Vera Cruz not subject to tonnage duty.

Decree of May 10, 1856, establishment of certain colonies and tax exemptions therefor.

Decree of November 15, 1858. Though civil war was going on the government will not tolerate any act of violence against foreigners. They are to be held exempt from all military service and forced loans. "The honor and good name of the Republic and the preservation of its harmonious relations with foreign powers" demand that the rights of foreigners be scrupulously observed.

Decree of March 13, 1861. Exempting from taxation for five years foreigners who purchase lands for agricultural purposes or for any rural industry. Colonizing companies and members of the colonies granted tax exemption for ten years. Granting additional tax exemptions for five years to foreigners who employ Mexicans. Granting freedom from customs for importations of goods for foreign colonists under certain conditions.

Proclamation of the Governor of Sinaloa, January 2, 1862, devoting one-half of the vacant land and waters to encouragement of national and foreign immigration. Lands to be given freely to colonists who will survey and develop them. They are also to have freedom from military service.

Other citations are found in Recopilación de las leyes, decretos $y$ proclamaciones de la union, quoted in Papers Relating to the Foreign Relations of the United States, 1888, vol. 2. Among which is Circular of the Secretary of Improvement, Colonization, Industry and Commerce, August 25, 1877. It cites failure of former legislation to attract immigration and predicts that the tide will now turn toward Mexico. Peace established and the government "is resolved to make all kinds of sacrifices in order to attract honorable and industrious foreigners to our favored soil. . .." 
relative to the advantages that will result to the Republic by permitting foreigners to acquire property therein" it had been decided that "a frank policy and an interest well understood demand that no further delay be permitted in making such concessions as may tend to the prosperity and development of the Republic by the increase of population, by the extension and division of property ... taking also into consideration the fact that by these measures the security of the nation will be more assured, since the foreigners who are owners of property . . . will be so many defenders of the national rights, considering also the encouragement which will be received by agriculture, commerce, and other industries, which are the fountains of public wealth; and lastly, that the opinion generally manifested is in favor of the concession," it was decreed that foreigners could acquire real estate freely but not more than two country properties in the same department. Foreigners employed in operation of such properties were not subject to military service except of a police character. Though this decree issued from the central government, it did not overthrow the rule that colonization projects were still in the hands of the states.

The war with the United States brought to those interested in colonization a conflict of feeling. They felt that colonization was responsible for the national disaster, which ended with the loss of about half of Mexico's territory, yet they continued to believe that only by colonization could the republic which "found itself spread abroad in an immense territory divided by high mountains, by great rivers, and deserts, which could not be 


\section{MEXICO AND I'TS RECONSTRUC'TION}

crossed," hold itself together. Its misfortune had been the result of its impotence and of the fact that its more remote districts "found themselves almost foreign . . . to the civilization of the center of the country." For a time efforts seem to have been confined to internal colonization. Military colonies were set up, especially on the northern frontier where "invasions by adventurers from Upper California" were feared. Thirty of these outposts were established, seven in Sonora, seven in Chihuahua, four in Nuevo Leon, six in Coahuila, four in Durango, and two in Lower California. But the enemies of order were not alone in the north and similar establishments had to be set up in Tehuantepec, Querétaro, San Luis Potosí, and even in the State of Mexico itself. These colonies were of $\mathbf{1 0 0}$ mounted men and their families, to whom, in return for a promise to stay in the colony six years, the government gave a monthly salary, land, construction materials, laboring tools, and seeds for the first crop. ${ }^{7}$ The settlements were, of course, of exceptional character; they did not promise to satisfy the country's need for greater population nor the desire for European population. Further, the settlements once established could not be given the promised support, because of the poverty of the treasury. ${ }^{8}$

How real was the Mexican need of immigration is shown by comparing her population and her area. The states of the northern frontier were possessed but in no

${ }^{7}$ Manuel Robles, op cit., republished in Manero, op. cit., p. 28 et seq.

${ }^{8}$ Memoria of the Secretary of War, Ignacio Mejia, 1873, published in Manero, op. cit., p. 64. 
true sense occupied. Lower California, over which neither Spain nor Mexico had ever had effective control, was practically without inhabitants-it had about one inhabitant to every seven square miles. The character of the country there, it is true, assured that it would never support any large population. The frontier units to the eastward made a somewhat better showing. Sonora had 1.69 inhabitants per square mile, Tamaulipas on the Gulf of Mexico had 3.07. The frontier divisions, with an area of about 400,000 square miles, or over half of that of the republic, had a population of less than a million, and that population lived under such conditions that its rapid increase and material progress were unlikely. ${ }^{\circ}$

Practically a generation after state promotion of colonization was authorized it was confessedly a failure. Colonists were unwilling to come to a country torn by disorder. The state governments were not strong enough to carry out the subsidies they promised. The modifications adopted after 1824 were not acted upon any more than the original measure. On June 1, 1839, a great quantity of lands was marked out, which was to be sold for payment of the public debt. Seventeen years later not a single conversion had been made. On December 4, 1846, a junta of distinguished persons was created to foster colonization but nothing was done. In 32 years following 1824 not a single colony had been formed, by a state, of individuals who had come from

- The statistics for 1861 , on which this estimate is made are, at best, only approximately correct. They are taken from Carlos Butterfield, The United States and Mexico, Washington, 1861, pp. 9-11. 


\section{MEXICO AND ITS RECONSTRUCTION}

outside the republic. Lands had been disposed of by the states, it is true; they sold "concessions" and when they could not do so, they gave them away. They even disregarded the rule against alienation to foreigners of the lands near the border and the coast, but nothing was done "which merits the name of colonization." 10

State colonization had proven such a fiasco that, after examining many grants, it was decided to annul all acts taken under the legislation that established the system. On November 25, 1853, all alienations of land since 1821 were declared void. The central government now tried its hand. On the 16th of February of the following year a decree was issued inviting European immigration and offering to settlers land and pecuniary aid. President Santa Ana then appointed a Spaniard, General Agent of Colonization, to whom he gave nearly $\mathbf{5 0 , 0 0 0}$ pesos with which the appointee promptly disappeared. Other contracts were made in $\mathbf{1 8 5 6}$ for colonizing Germans in Nuevo Leon, Jalapa, and Vera Cruz and the consul of Genoa contracted to bring over a colony of Sardinians. Colonies in Sonora and Durango were to be of persons from Upper California. Others were planned in Yucatan, Chihuahua, and the Federal District. All these ventures met the same fate. What the states had not been able to do, the central government did no better. Ministers of Fomento, or the Interior, had to report failure after failure. Immigrants turned aside from Mexico to the northward. ${ }^{11}$

${ }^{10}$ Manuel Siliceo, op. cit., in Vicente E. Manero, op. cit., pp. 47-50.

${ }^{11}$ Lists of colonization enterprises and statements of their troubles 
The next serious attempt to deal with the colonization problem was made in the '70s by the eminent Secretary. of Fomento, Vicente Riva Palacio. By this time it was realized that the government owed it to the public treasury to see that the public lands were not carelessly disposed of to companies that had no sericus purpose to develop them or to promote immigration. It was recognized that lands that had been alienated could not be taken again without payment, but the government should ascertain what land it held and in the future dispose of it only in ways that would fully protect the rights of the nation. On August 25, 1877, the Secretary addressed to the governors of the states a circular that indicated both the problem confronting the administration and how ill fitted the government was to cope with it. Colonization legislation, it was shown, still proved a failure; colonization, however, was one of the greatest needs of the country, ${ }^{12}$ but the government, unlike that of the republic to the north, had no way of telling where public land lay nor what was its extent.

The state governors were asked to outline the system adopted locally to handle immigrants on their arrival. They were asked to inform the central government what,

in later years are found in Memoria of D. Luis Robles, Minister of Fomento, 1865, and Memorial of D. Blas Balcaral, Minister of Fomento, 1868, published in Manero, op. cit., pp. 53-9.

${ }_{12}$ President Diaz in his address to Congress declared immigration to be one of the "imperious necessities of the republic," Papers Relating to the Foreign Relations of the United States, 1878, p. 526, quoting the address of President Diaz to Congress as printed in The Two Republics, September 29, 1877. 


\section{MEXICO AND ITS RECONSTRUCTION}

if any, lands belonged to it within their respective commonwealths, what the fertility of such lands might be, and what would be a fair price. In short the government confessed a complete "lack of knowledge of the whereabouts of the national lands, due to the fact that they are not explored nor surveyed." Obviously it was "impossible that the central government should divide what it does not know of among settlers." 13

The answers received were disappointing. There was in no state any system of taking care of immigrants worthy the name and the state governments were as ignorant of where the national lands were as was the central government itself. ${ }^{14}$ All agreed that immigration of foreigners and foreign capital were needed to rouse Mexico from its inactivity but none had succeeded in attracting either. A series of letters to the agents of Mexico in foreign countries brought answers not more encouraging. Their general tenor was that Mexico could not hope to attract immigration so long as the United States offered lands on better terms. If the country put its house in order and could point out definite lands that would be given to foreigners, some might come. Even so, many would not come to Mexico because it was largely a tropical country and in the opinion of many immigrants wholly so.

13 Circular of Riva Palacio published in Manero, op. cit., pp. 89-91.

24 The answers are published in detail in Anexo Num. 3 a la Memoria de hacienda del año economico, de 1877 a 1878, Estadistica de la republica Mexicana . . Emiliano Busto, Mexico, 1880. 
The discouragement then felt has proved to be justified. The government has continued its efforts, but with little success. Those who headed the numerous colonization enterprises of the period often received a fixed sum plus a bonus of as much as $\$ 35$ or $\$ 60$ for each immigrant above seven years of age. Additional bonuses were normally forthcoming for the establishment of families. One contract bound the government to pay $\$ 700$ for each European agriculturist and $\$ 350$ for each member of his family over seven years of age. One stipulated a payment of $\$ 315,000$ annually for 30 years. The colonization contracts granted in the three years 1881-3 would have taken from the treasury $\$ 800,000$ per annum had the enterprises been successful..$^{15}$ On December 15, 1883, another liberal and comprehensive colonization law was passed. It did not, however, bring settlers.

In 1892, roughly at the middle of the Diaz régime, the Ministry of Hacienda was still hopeful that conditions would change. It was declared that every immigrant was worth 10,000 pesos to the country and that soon the long looked-for stream of colonists was sure to come. The United States would soon fill up, "this at least within the period of a few years" "and then the current of emigration, until now directed toward them will have to seek a new field." ${ }^{16}$ To hasten that end a new colonization law was adopted on March 26, 1894, removing

${ }^{15}$ Papers Relating to the Foreign Relations of the United States, 1883-4, p. 637.

${ }^{16}$ Memoria de hacienda y crédito público . . . de Julio de 1891, a 30 de Junio de Mexico, 1892, p. 21 et seq. 


\section{MEXICO AND ITS RECONSTRUCTION}

the limit of 2,500 hectares, which former legislation had allowed to be granted to one person. ${ }^{17}$

As time went on free land could no longer be secured in the United States, order was established in Mexico, and commerce was freed from its former limitations. These circumstances, which, it was thought, explained failure of immigrants to come to the republic, disappeared but settlers did not turn their steps southward. Foreign capital went to Mexico and with it the managers who would supervise the industrial undertakings, which order within the republic made possible. But the laborer who, by performance and the example he would give the native, was to transform its entire economic structure did not come in great numbers.

A few scattered colonies have come into existence that have had some prosperity. The Mormon colonies in the northwest are the most important. Two Italian colonies of specially chosen, vigorous men are reported to be prospering ${ }^{18}$ and there are groups of foreign nationality in other parts of the republic, which are, however, not as a rule "colonies" in the sense in which that word has been used in Mexico. In fact real agricultural colonization in the extensive way in which the republic had hoped to secure it has never had a single example. ${ }^{19}$

${ }^{17} \mathrm{~A}$ general description of the land legislation is found in Charles H. Stephan, Le Mexique economique, Paris, 1903, pp. 221-242.

${ }^{18}$ Alberto Robles Gil, Memoria de la secretaria de fomento presentada al congreso de la union, Mexico, 1913, p. 94.

${ }^{19}$ The hope that European colonists may come is still voiced. It was declared fundamental at the sessions of the National Chamber of Commerce of Aguascalientes. See Circular No. 98 in Alberto Robles Gil, op cit., p. 501 et seq. 
It remains true to-day, as it always has been true, that Mexico is a land in which Western European peoples can succeed as colonists only under the most exceptional conditions. As a French writer of the beginning of the century declares, "If you have no money, only strong arms and good habits, do not come to Mexico for you will find in competition several millions of Indian laborers who have arms and sufficiently good habits for farm work and who are satisfied with salaries which would make your condition more miserable here than at home." 20

After the early '80s there was a small but increasing immigration of foreigners into Mexico, not as members of organized colonies, but as individuals or members of groups who came to develop some of the latent industries. The most numerous of these immigrants were Spaniards and later Americans. Of the latter, the immigration before the railway era was negligible. Many of those who went to Mexico failed and had to ask the aid of charity to enable them to return. The people who went to Mexico from the southern states after the Civil War failed. Those who did not die, with few exceptions, came back. The attempts to colonize Lower California from the United States failed also.

Nevertheless, with the development of better economic conditions in Mexico, the number of individual Americans who suceeded in making homes in the country increased. Some were those whose presence was no longer welcomed in their home countries, but the great

${ }^{20}$ Charles H. Stephan, op cit., p. 240. 


\section{MEXICO AND ITS RECONSTRUCTION}

majority left the communities they abandoned poorer by their absence. They were a forceful and adventurous contribution. They did not expect and they did not find the routine sort of life that they left in the better settled north. They did not go to Mexico without hope of great gains, larger gains, at least, than had been possible in the countries from which they came. For this they are not to be blamed-who risks fortune, health, and life in a rough and ill-ordered frontier community unless there be some lodestone of opportunity to draw him from the surroundings among which he was born? They were promised protection, rights such as were guaranteed them at home, in a new land where opportunities were alluring. They accepted the new life, willing to endure its privations, as a return for its opportunities. That they received the sort of protection they were promised and expected 'can not be maintained. Buffeted by the natural disadvantages of the frontier, their enterprises limited by the ignorance of the laborers upon whom they had to rely, and too often harassed by the local governments whose promises had been their illusion, their lot was not an enviable one. That they made a success of their ventures is evidence of their individual capacity. As the Diaz régime progressed they were given better protection of their rights. They could look forward to a day when life and property could be enjoyed under conditions of safety approaching those of the land they had left. They conferred a great and too often unappreciated boon upon the republic which was their host. The pioneers, by their success, won in spite of repeated disappointments and misfortune, drew 
other foreigners after them. The stagnant Mexican life of the middle century was stimulated by their enterprise. Foreign capital entered new fields, into which the insufficient and timid local capital would not venture. The foreigner created new national wealth, which laid the foundation for greater national income and for a government that might in time have approached true republican standards.

Shrewd was the discernment of the Mexican statesmen who saw in those who came from beyond the national boundaries the salvation of their backward country. What they failed to secure by means of "colonies" they received in large degree by the coming of the fearless and enterprising individuals who entered the local life to transform it. Without the foreigner, it is safe to say, Mexico would not have reached for generations the condition of which she was justly proud in the beginning of the century. In some cases Mexico has paid heavily for his aid, but to the great mass of foreigners who made her lot their own Mexico owes a debt of gratitude that she cannot repay.

Nevertheless neither American nor any other foreign immigration has as yet helped solve the greater number of the fundamental problems that Mexico had hoped would be settled by her colonization and immigration legislation. The economic basis of the country was remade but the native population was not leavened.

If foreign laborers will not come to give impetus by their manual skill and industry to the national life, the only recourse is to try by other means to attain the same end. Of late years attention has been turning gradually 


\section{MEXICO AND ITS RECONSTRUCTION}

to the necessity of educating the Indian in industrial pursuits. A few realized this necessity a generation ago. In 1892 one of the far-seeing declared: "The duty of the government is to civilize these co-citizens of ours ... to place them in contact with the rest of the country and with the civilized world. ... When the Indians, up to the present time disinherited, are subject to the advantages and comforts of civilization, there will have been accomplished, so to speak, the transporting to our country of millions of colonists." ${ }^{21}$ But this task the men of the old régime overlooked, as a rule, or, if they appreciated it, neglected. It was the greatest failure of the brilliant exploit which Diaz and his lieutenants accomplished. They brought an economic transformation to Mexico but they left its social structure very much as they found it.

This is the most important task of the government that will rise out of the Mexican revolution-to drive the Indian from his self-contented, unprogressive state of few desires and waken him to new economic, political, and social opportunities and responsibilities. If Mexico is to be for the Mexicans in any real way, some means of bringing this change must be found. If it is not found and the Indian proves unable to respond to the new conditions now rapidly rising around him, he will become the hewer of wood and drawer of water for the white man who comes to develop the natural resources of his country, or he will be crowded gradually into the less desirable regions of his native land where his ex-

${ }^{21}$ Memoria de hacienda y crédito público de 1 de Julio de 1891 a 30 de Junio de 1892, Mexico, 1892. 
perience will parallel that of the native tribes in the United States. Because of the varied climate of the country it is not unlikely that both these processes may occur in different portions of the republic at the same time.

One of the means advocated for dealing with the problem of awakening the ambitions of the lower class Mexican is so-called internal colonization. Unlike other colonization projects this movement is not to depend on foreigners nor to have a military basis. It is not even necessarily to involve transfer of persons from thickly. settled to sparsely settled areas.

Under supervision of the federal government it is argued there should be maintained a comprehensive system of agricultural education. There should be established in various parts of the country native agricultural colonies in which agricultural experiment work would be carried on by the younger men. To each would be given a plot, the produce of which would be his own. The government would stimulate competition by granting prizes. Instruction in agricultural methods would be given. Allied with such enterprises could go legislation that would encourage the use of natives in the higher positions in the various industrial establishments, thus making the economic development of the country contribute directly and in the most practical way to the schooling of the rising generation. ${ }^{22}$ These projects aim to assure that if the foreigner himself will not come in the way the governments had once thought possible,

${ }^{22}$ E. Maqueo Castellanos, Algunos problemas nacionales, Mexico, 1909 (1910), pp. 110-116 et seq. 


\section{MEXICO AND ITS RECONSTRUCTION}

there shall at least be brought to the native population the benefit of the enterprise and scientific progress of foreign lands. Of such "foreign influence" there need be no fear and of it no nation can have too much. For the prosperity of the Mexican and for that of the interests of foreigners in the republic it is to be hoped that internal colonization may have the fullest success. 


\section{CHAP'TER XVIII}

\section{THE FOREIGNER IN MEXICO: HIS PROPERTY}

Is all the long drawn out discussion of the rôle of foreign capital in Mexico there has been much invective on both sides and on both sides there is the greatest need of clear thinking. Foreign capital is pictured as was railway development a generation ago. It is looked upon as carrying a possibility of the overthrow of Mexican independence. It does so. Foreign capital at the same time is the greatest hope for the salvation of the republic.

It is doubtful whether Mexico has suffered from the so-called "curse of concessions" to a greater degree than the average undeveloped country, and she has profited tremendously by the coöperation of foreign capital secured by favors granted in order to induce the assumption of her unusual business risks.

Mexico, a generation ago, was in a condition through which many a country has passed. She had a great extent of territory and a sparse population. She had great natural resources, which her people knew not how to develop and which they could not have developed rapidly even if they had known how, without the help of capital from outside the country. Under these conditions Mexico did what other countries have done in similar circumstances. Like the United States, like Argentina, she recognized the need of outside help and she 


\section{MEXICO AND ITS RECONSTRUCTION}

granted special favors to those who could give it. That the foreigner was disposed to drive a hard bargain, in some cases, is true. It is not surprising if, in some cases, too much was granted. It is too much to expect that corruption in such dealings should always have been absent. Certainly the experience of other countries does not show that they have been able to escape such pitfalls.

The last quarter of the nineteenth century was one in which there was a world-wide demand for great amounts of capital to develop, among other regions, the western United States, South America, Siberia, and South Africa, as well as to carry through a remarkable industrial advance in both Europe and America. It was not to be expected that Mexico, under such circumstances, could secure capital upon as favorable terms as might have been the case otherwise. Taken all in all there seems to be little reason to believe that the country fared any worse in this matter-or any better-than it deserved or than other countries under similar circumstances have fared.

What the "concessions" involved is often less clear in the minds of critics than is the conviction that abuse has occurred. As a rule the pre-Diaz concessions have little importance, because any money that the promoters put into them they lost and the "concession" lapsed without benefit to the grantee nor harm to Mexico. There were all sorts of schemes proposed in that period. Colonization enterprises of fantastic nature often were concessions and some of the grants of doubtful character in later days have been colonization schemes.

The great majority of the concessions were simple 
grants of exemptions from taxes, made under a policy of public improvement. The central government and the states in the Diaz régime openly declared for this method of development and there was then no local or foreign opinion condemning it. ${ }^{1}$ In spite of the widespread prejudice, which has been aroused in later years against any such contracts, the successors of Diaz have indicated a belief in its wisdom by holding out the same sort of inducements.

The freedom from taxation, which was the sum and substance of the typical concession, was an encouragement given to industry and commerce, a favor granted to persons who would establish new industries in the communities or open up a new national resource. The terms of many of the contracts in the states were long, running up to 25,30 , and even 50 years. In many cases, doubtless, these did represent too liberal a standard. Practically any sort of new enterprise could secure a grant. The list of the concessions in the various states at the end of the Diaz régime included widely contrasted enterprises such as theaters, fishing companies, ice factories, colonization enterprises, refining plants, flour mills, banks, liquor shops, and clothes factories. ${ }^{2}$

What amount of foreign capital has actually been invested in Mexico it is impossible to determine. Capital

${ }^{1}$ An example of the propagandist literature that has since arisen criticizing the granting of concessions is C. Fornaro (and others), Carranza and Mexico, New York, 1915.

${ }^{2} \mathrm{~A}$ list of the more recent concessions granted in the various states giving their terms is published in Memoria de hacienda $y$ crédito público, correspondiente al año economico de 1 de Julio de 1910 a 30 de Junio de 1911, Mexico, 1912, p. 594. 


\section{MEXICO AND ITS RECONSTRUCTION}

is never prone to declare its existence for the making of public records, especially in countries where such records may be made the basis of tax collection or forced loans during periods of revolution. That the valuations in tax assessments are in most countries far below the actual worth of property is notorious and Mexico is no exception. On the other hand, whenever interests claim damages from their own or from foreign governments, they have a tendency to exaggerate the importance of their violated property rights and the degree of persecution endured. To a less extent the same tendency to overstatement is found in the estimates made by those who describe the importance of their co-citizens' interests in foreign lands.

American investments in Mexico are greater than those from any other foreign country. The estimates of their total amount are many. Two coming from consular officers of the United States have a semi-official character. Neither claims to be complete and there are points in which each is subject to criticism for underestimate and overestimate of certain items. That there is less probability of error than in other approximations is indicated by the detailed information they contain.

Consul General Barlow's estimate published by the Bureau of American Republics in 1904-5 indicated that the American money invested in Mexico at the beginning of the century by 1,117 American companies and individuals was about $\$ 500,000,000$ gold. Practically all of it had been introduced in the previous 25 years and about half of it in the five years preceding the report. The greatest single American interest was the 
railroads, in which about 70 per cent of the investment was American. Of the railroads, the Mexican Central had the most American capital, followed by the Mexican National. In mining, Americans had invested \$80,$\mathbf{0 0 0 , 0 0 0}$, in agriculture, $\$ 28,000,000$. In manufacture, American enterprise had already begun to make investment in sugar refineries in Sinaloa, in various enterprises in the Federal District and in Nuevo Leon, especially at Monterey. All the large smelters were American.

The announced location of American capital in Mexico at this time is unsatisfactory, because the railroad investments are all credited to the city in which their chief offices were located. In Mexico City, thus, there were announced to be American investments valued at $\$ 320,800,000$ and in Coahuila American properties worth $\$ 48,700,000$, the greater part in each case representing railroads. Sonora had $\$ 37,500,000$ worth of American capital invested, of which $\$ 27,800,000$ was attributed to mining ventures. Of the $\$ 31,900,000$ in Chihuahua, $\$ 21,300,000$ was in mining. American capital in Oaxaca totaled $\$ 13,600,000$ and in Nuevo Leon, $\$ 11,400,000$. $^{8}$

Investments continued to be made in Mexico at a very rapid rate during the years following this report. Consul General Marion Letcher reported statistics in 1912, compiled by a mining engineer of long residence in Mexico, that indicated $\$ 1,057,770,000$ American cap-

${ }^{3}$ House Document 145, Part V, 58th Congress, 3rd Session (1904-5), International Bureau of the Amerícan Republics, Mexico, pp. 257-259, quoting a report by Consul General Barlow. 


\section{MEXICO AND ITS RECONSTRUCTION}

ital invested in the country. The greatest single American interest continued to be in the railroads, stocks and bonds of which were held to a value of $\$ 644,390,000$. The estimate of money invested in mines had now risen to $\$ 223,000,000$, and $\$ 15,000,000$ or more was credited to each of the following: national bonds, smelters, bank deposits, rubber production, and the oil industry. Obviously, a development of investments on so large a scale was helping with the other changes in local conditions to bind the economic interests of the two countries together very rapidly and was giving an unprecedented stimulus to Mexican life. ${ }^{4}$

Next in value after American investments this compilation ranked those of British citizens. The total value of these properties was $\$ 321,302,800$. The chief items were railways, national bonds, and mines. British citizens were stated to be the largest foreign holders of national bonds, timber lands, and tramways. Investments by them, like those by Americans, appear to have been rapidly increasing. It is to be noted that in these estimates the oil properties were still of small value compared to that which they have subsequently reached.

A detailed list of British holdings in Mexico, published in 1919 , put the total at more than $\$ 500,000,000$ American gold. The amounts, in various lines, were ap-

${ }^{4}$ Statistics from Daily Consular and Trade Reports, July 18, 1912 , p. 316. The estimates are reported to be based on government and state reports, directories of business houses, factories, mines, and smelters, La Mexique, the Mexican year-book, and numerous reviews, encyclopedias, and company reports. The Statist (London), November 29, 1919, gave “a little over 300 millions sterling" as the value of American holdings. 
proximately as follows: petroleum companies, \$120,000,000 ; mining companies, $\$ 85,000,000$; light, power, and street railway companies, $\$ 145,000,000$; divers industries, $\$ 40,000,000$; and banks, $\$ 70,000,000$. $^{5}$ In the same year another writer put the total as high as $\$ 800$,000,000 gold. ${ }^{6}$

The American authority above cited reported French investments in 1912 as totaling $\$ 143,446,000$, of which national bonds and bank stocks formed almost twothirds. Frenchmen were far the most important foreign investors in cotton mills, wholesale stores, and tobacco factories.

In 1914 French residents in Mexico claimed that there were French holdings there amounting to several thousand million francs invested in government obligations, banks, railways, electric transportation, mills, factories, and businesses of every kind. Among the more important French interests were mentioned mines such as Dos Estrellas and El Boleo, industrial establishments such as the Buen Tono, tobacco factory, the chief Orizaba textile mills, and the large French stores in various cities. ${ }^{\text {? }}$

German interest in Mexico began early. In the Maximilian régime a colony of $\mathbf{5 0 0}$ was brought from Schles-

${ }^{5}$ Quoted in Nerw York Times, October 26, 1919, from an article originally appearing in El Universal, of Mexico City.

'South American Journal, September 13, 1919. The Statist (London), November 29, 1919, gives "between 200 and 250 millions sterling" as the amount of British interests.

' Unnamed Paris correspondent in the Nation, vol. 98, p. 290, March 19, 1914. 


\section{MEXICO AND ITS RECONSTRUCTION}

wig-Holstein to Yucatan but the venture proved a failure. The few who remained in the country were soon absorbed into the local population. The unfortunate results discouraged further colonization en masse but in later years Germans have come individually and have adjusted themselves to Mexican conditions with success. German writers proclaim Mexico as a land well suited for a large immigration. There the colonist lives the national life without losing his love for the fatherland, his principles, and his upbringing. "Wherever in the world there are a hundred Germans, there is also a German school with the task of teaching within its walls the holy love of the fatherland and the fruitful high German kultur." "In traveling through these wide unpopulated districts of Mexico, there unconsciously comes to one the thought of the great density of population at home in Germany, where people are packed like herrings in a cask, and one cannot avoid the desire to take . . a couple of millions of poor beings to whom light and air are denied over there and ... put them down in the boundless, fruitful open spaces of Mexico." 8

No detailed analysis of German investments in Mexico is available. A writer at the end of the Diaz régime estimated the total working capital invested at the equivalent of $\$ 75,000,000 .^{9}$ Germans did not enter largely into the industrial development of Mexico, except in later years in certain mining developments. Mercantile development showed their influence to a greater ex-

${ }^{8}$ Erich Gunther, Handbuch von Mexica, Leipzig, 1912.

${ }^{9}$ See Karl Sapper, Wirtschaftsgeographie von Mexico, 1908, for a discussion of German interests in Mexico. 
tent. ${ }^{10}$ German enterprise was represented by a large number of wholesale and retail dealers in hardware, chemicals, and small commodities. The transactions in these lines brought them into closer contact with the Mexican public than any other class of foreigners except the Spaniards. They, like the Spaniards, were not conspicuous as developers of the great natural resources of the country and prejudice against them seems to have been less than against any other foreign element, especially after it became evident that the United States would be drawn into the World War on the side of the Allies. To the Germans, too, the revolution brought less percentage of loss than to the Americans and British. Mercantile stocks can be adjusted to changing political conditions more easily than can public services, mines, and similar enterprises.

What the total amount of foreign capital in Mexico is and what is its relation to the total national wealth must, like the individual items, be matters of estimate. The American consular report of 1912 put the total value of all the enumerated properties at $\$ 2,432,000,000$ and those of Mexican ownership at $\$ 793,187,242$. It appears that the comparison must understate the value of Mexican holdings. An article published by a former member of the United States consular service at the close of the revolution makes an estimate of $\$ 1,875,000$,000 as the total foreign investment divided as follows: American, $\$ 665,000,000$; British, $\$ 670,000,000$; French,

${ }^{10}$ Anonymous article, "German Efforts in Mexico," World's Work, vol. 35, p. 208, December, 1917. 


\section{MEXICO AND ITS RECONSTRUCTION}

$\$ 285,000,000$; German, $\$ 75,000,000$; and various, $\$ 190$,$000,000 .^{11}$

Whatever the total, it is natural that foreign countries should be anxious that the rights of their citizens should be given proper protection. It is also natural that Mexico should seek, by all proper means, to create conditions by which she can gradually make herself less dependent on capital from beyond her frontiers. Unfortunately, this desire has not at all times been accompanied by a determination to respect property rights already acquired.

Envy of the position into which the enterprise of the foreigner had carried him was by no means absent, even before the revolution. Mexico has welcomed the foreigner as the means of her salvation but she has been jealous of him also. She has wished to have the country profit by his individual initiative and example but, at the same time, she has wished to minimize his influence in the republic, and, if possible, make him drop his privileges as a foreigner and become subject to Mexican law exclusively. Mexico has welcomed foreign capital also, but she has sought to make it drop its nationality at the border. She has wished to secure its coöperation as capital, not as foreign capital. Toward both capital and the immigrant, in short, she has stood in an equivocal position. She has sought the benefits they could bring without being willing to assume the responsibilities that accompany those benefits.

${ }^{11}$ Quoted in the Guaranty Neres, August 19, 1919, Guaranty Trust Company of New York, from an announcement of July 15, 1919, by the Mexican International Corporation. 
But in the period before the revolution, Mexico realized that to secure foreign coöperation she must forego her prejudices. She failed to denationalize her immigrants. The foreign capital, which entered her great development enterprises, would not give up its right to look to the home country when justice was denied. Later, when capital had undertaken certain important developments and was receiving unusual returns for the unusual risk assumed, there was frequently a feeling that the special privilege granted was too generous or that it was secured from a government under duress or by corrupt means. But in the Diaz régime, though there were protests, the government stood firm for the fulfillment of the engagements made.

With the outbreak of the revolution it is not surprising to find that the new political leaders took advantage of popular discontent with the results of the policy followed by their predecessors, nor is it surprising to find them embarrassed as the revolution comes to a close, when they are now brought to realize that the promises made to their followers may be difficult to fulfill. To declare against the "curse of concessions" and to secure supporters at home and abroad for a campaign to free the country from alleged oppression is easy, but it is difficult to justify the nation in trying to escape from the responsibility of paying for the benefits it secured through the grants against which complaint is made.

In individual cases it is often difficult to determine whether abuses were involved in the original concessions. There are few who would defend them if they are shown to exist. TThe only regret is that even such 


\section{MEXICO AND ITS RECONSTRUCTION}

cases have become so much a matter of history that effective correction is, as a rule, beyond the powers of the government, whatever its good intent may be. In the great majority of cases, too, the record of the foreign interest is one that shows property rights acquired under the conditions laid down by Mexican law and involving privileges, if at all special, only of a kind that the granting government was not only willing, but anxious, to give. An attack upon property rights of this nature by Mexico can not leave the foreign powers, whose citizens' rights are involved, without concern.

At best foreigners have endured heavy losses during the revolution. No country can suffer from a far-reaching revolutionary activity for a decade without great damage to property rights of all sorts. The government that finally establishes itself assumes, as a matter of course, the duty to pay all proper claims arising out of the hostilities. It is not only this responsibility which is under discussion in connection with the property rights of foreigners in Mexico but the obligation on the part of the republic to adopt toward undestroyed foreign property rights a policy that shall not amount to confiscation, and that shall not be directed against foreign capital merely because it is foreign, irrespective of the conditions under which the interests in question may have joined their lot to that of the republic.

It is the declarations of Mexican leaders and the legislation adopted that seems to offend in this particular that have caused the greatest doubt in the mind of foreigners and their governments as to whether they can count upon justice and the maintenance of standards of 
international friendship by the governments that claim the fruits of the revolution. President Carranza was quoted as saying: "We wish foreign capital but we will not give one special privilege, not one." 12 What such declarations mean is not clear, either from the use of such words in the past in the republic nor from the practice of those who now use them. What that characteristic of a privilege is that makes it special, so as to be objectionable, is by no means always easy to determine. It has long been a matter of dispute in the interpretation of constitutions and laws in the United States and elsewhere.

Is a special privilege, as that word is used in discussions of Mexican affairs, one which refers to an exclusive right to certain property? That can hardly be, for upon the basis of individual and corporate ownership of property all modern governments rest. If a privilege as to place is not in essence special and objectionable, is one giving rights not enjoyed by all, over a certain time or in regard to certain property, a special and objectionable privilege? Is exemption from taxation for a certain period, or the grant of public land, as reward for establishing a colony, introducing a new industry, or undertaking a public improvement a special privilege not to be endured? Is freedom to import the materials for constructing a manufacturing plant or a railroad never to be given because it is a special privilege? In the popular sense of the word such grants are undoubtedly special, but that such privileges may operate for

${ }^{12}$ World's Work, vol. 31, p. 124, 1915. 
the public good has been accepted generally both in and out of Mexico and in Mexico such grants have been enjoyed by both Mexicans and foreigners alike. If such be the privileges, which the government is to bring to an end, and if the policy is to apply only to future developments, foreign capital may be disappointed, but there can be no valid cause of complaint.

But, if Mexico is free to encourage or discourage foreign capital that might enter the country to develop property within it by granting or withholding the special privileges above mentioned, she is not free to adopt any attitude she may wish toward foreign interests already established within her borders. Mexico is not free to denationalize at will the foreign capital which, at her invitation, has crossed her boundaries. She can not captiously modify the contracts which she has herself permitted and encouraged and she can not arbitrarily denationalize her resident foreigners. ${ }^{13}$

${ }^{13}$ For former attempts, see Papers Relating to the Foreign Relations of the United States, 1883-4, pp. 651-4. 


\section{CHAPTER XIX}

THE FOREIGNER IN MEXICO: HIS LEGAL POSITION

IT has been said already that it does not seem profitable to discuss the general organization of the government of Mexico under the constitution of 1917 as compared to that under the constitution of 1857. Constitutions have never been a set rule of action in Mexico and a consideration of the actual conditions within the republic gives little hope that it will be possible to make the political provisions of the Constitution of 1917 function as was intended, until fundamental changes have been accomplished in the social, educational, and economic equipment of the people. The reconstruction of Mexico involves problems deeper than those that can be settled by constitution makers.

It is important, however, to consider the terms of the new Constitution applying to foreigners and their rights, because the manner of the enforcement of these has an immediate bearing on Mexico's relations to other powers and the interpretation, which the governments of the reconstruction period may adopt upon these matters, will determine Mexico's international credit and possibly the continuance of her peaceful relations with other nations. In short, the conditions under which Mexico may work out its own reconstruction and whether it will be allowed to work out its own reconstruction may depend upon its willingness to assume 


\section{MEXICO AND ITS RECONSTRUCTION}

the responsibilities of dealing justly with those of other nationalities, who have acquired rights within its borders.

This is not wholly or chiefly a question of constitutions; it is more a question of the attitude of the government in the interpretation of doubtful clauses of the constitutions. The fundamental law of 1857 had in it objectionable clauses but the government of General Diaz, as time went on, showed itself indisposed to interpret them in a way that would discriminate against foreigners. The Constitution of $\mathbf{1 9 1 7}$ has additional indefinite provisions and the governments in power since its adoption have acted in a way to arouse apprehension on the part of foreigners owning property in the country.

The preamble of the new Constitution, like that of the old, contains a clause, which, broadly interpreted, would protect all vested rights. It declares: "No law shall be given retroactive effect to the prejudice of any person whatsoever." 1 The other clauses that are of special interest to foreign holders of property, though some of them do carry discriminations, are not ones to which international objection may be raised if this general guarantee is in law and practice one which limits all other clauses. If it does not do so, if the rule that a more specific provision of law controls a more general one applies, then certain of the clauses of the new Constitution give good reason for alarm.

${ }^{1}$ Article 14. The citations of the Mexican Constitutions in this chapter are based on H. N. Branch, The Mexican Constitution of 1917 Compared with the Constitution of 1857, Philadelphia, 1917. 
Only the more important of the doubtful clauses can be discussed here. As to landholding, the Constitution declares that:

Only Mexicans by birth or naturalization and Mexican companies have the right to acquire ownership in lands, waters, and their appurtenances or to obtain concessions to develop mines, waters, or mineral fuels in the Republic of Mexico. The nation may grant the same right to foreigners, provided they agree before the Department of Foreign Affairs to be considered Mexicans in respect to such property, and accordingly not to invoke the protection of their Governments in respect to the same, under penalty, in case of breach, of forfeiture to the nation of property so acquired. ${ }^{2}$

Mexico doubtless has the right to apply the rule stated in the first sentence to all future grants, if she wishes. It may be that the rule would be considered unfriendly by other nations and it appears beyond doubt that such a rule would check the development of the republic. Nevertheless, there is no obligation on nations to be either friendly or progressive. The second sentence is more objectionable. It would be more straightforward to rely on the unmodified enforcement of the standard expressed in the first sentence. The modification demands that an individual surrender a part of the rights he enjoys under international law as the condition of becoming a Mexican landholder. He is to surrender part of the rights regularly attaching to his status as a foreigner though he does not consent to become a Mexican. There is good reason to believe that many governments would consider the enforcement of such a

${ }^{2}$ Article 27. 


\section{MEXICO AND ITS RECONSTRUCTION}

constitutional provision unquestionably objectionable. Some might well refuse to be bound by such surrender of rights by their citizens. ${ }^{3}$

Legislation restricting the ownership by foreigners or certain classes of foreigners, of land within border and coast zones, has long standing in Mexico as is shown elsewhere. Such restrictions are still thought advisable. They are found in the Mining Law, which went into effect on January 1, 1910, ${ }^{4}$ and in the Constitution of 1917. Generally such rules have been ones to which the executive might make exceptions. In the new Constitution the prohibition is absolute. "Within a zone of 100 kilometers from the frontiers, and of 50 kilometers from the sea coast, no foreigner shall under any conditions acquire direct ownership of lands and waters." ${ }_{5}$ There seems no doubt that Mexico may, if it wishes, adopt such a rule for her future guidance.

There are a number of other clauses that may affect the property rights of foreigners, the interpretation of which is doubtful, such as those providing for the taking of certain properties for the benefit of "rural communities," the power of the executive to declare null certain

${ }^{3}$ It may again be pointed out that the importance of this and similar provisions depends on the action that the government takes under it. Article 33 of the Constitution of 1857 declared that foreigners must subject "themselves to the decisions and sentences of the tribunals, and shall not be entitled to seek other redress than that which the laws concede to Mexicans." On its face this seems to prohibit appeal to the home country but, if it was meant to do so, the government did not enforce the provision.

${ }^{4}$ See comment in Branch, op cit., p. 114.

${ }^{5}$ Article 27. 
contracts and concessions granted by former governments, the provisions concerning church property, ${ }^{\circ}$ and those concerning exemptions from taxation. ${ }^{7}$

The equivocal provisions most discussed up to the present time have been those referring to the oil resources of the republic. This has been true for a number of reasons. Oil production has rapidly increased and, on that account, has attracted attention. The Mexican oil supply was important in the World War and for that reason was watched with peculiar interest by partisans of both the allies and the central powers. Further, the leaders of the government in Mexico felt they had an opportunity to secure for the nation a great source of income from petroleum. They wanted to assure that the oil resources as yet undeveloped should be national property, they wanted to tax heavily the yield of the producing areas, and they showed a desire to manipulate the legislation affecting these areas in such a way that the government would have freedom from foreign interference in any measures it might adopt concerning the properties.

The provisions of the Constitution, under which the controversy has arisen, are those affecting general landholding and a special paragraph which reads:

In the nation is vested direct ownership of all minerals or substances which in veins, layers, masses, or beds constitute deposits whose nature is different from the components of the land, such as minerals from which metals and metaloids used

\footnotetext{
${ }^{6}$ Article 27, II.

${ }^{7}$ Article 28.
} 


\section{MEXICO AND ITS RECONSTRUCTION}

for industrial purposes are extracted; beds of precious stones, rock salt, and salt lakes formed directly by marine waters, products derived from the decomposition of rocks, when their exploitation requires underground work; phosphates, which may be used for fertilizers; solid mineral fuels; petroleum and all hydrocarbons-solid, liquid, or gaseous.

It is later provided that as to such property "the ownership of the Nation is inalienable" and that concessions to develop these resources can be granted "under the laws of Mexico only on condition that said resources be regularly developed, and on the further condition that the legal provisions be observed." 8 There are a number of reasons why this new constitutional provision is disturbing to owners of the lands affected and particularly to foreign owners. The nation is declared the owner of the property described and this ownership is declared inalienable. Does this overthrow any previous ownership? It is insisted by the owners of oil properties that the rule applying to petroleum has not been the same as that applying, for example, to gold and silver. The laws of 1884, 1892, and 1909 recognized that petroleum in the subsoil was the property of the owner of the soil. Relying on these assurances the investments in oil properties have been made. To enforce a claim of national ownership of petroleum fields now would be to confiscate the property purchased or at least its most

${ }^{8}$ Article 27. See also Frederic R. Kellogg, "The Mexican Oil Problem," Nation, October 5, 1918, and the following collections of documents and translations: "The Mexican Oil Question," n. p. n. d. (1919); "The Mexican Oil Controversy," n. p., October, 1920. 
valuable part. Such an act, of course, would be contrary to the letter and spirit of Article 14 on retroactive legislation already quoted.

Because of anxiety as to the meaning'of this provision Ambassador Fletcher, when presenting his credentials to the Mexican government, made inquiry on the point. He was assured that no confiscation was contemplated. The Mexican Revier, a semi-official paper published in Washington in the interest of the Carranza government, declared that the constitutional provision in regard to retroactive legislation protected all private holdings of lands.

About a year later-the first appearing, February $319,1919-$ a series of decrees were issued, which seemed again to show a conflict between profession and intent. Certain new taxes were placed on the petroleum industry but in the form of rentals and royalties. Titles to lands were to be registered and if not registered under the new law, the lands were to be declared open to entry. Ownership could be perfected only under the conditions outlined in the Constitution.

But, if ownership was already complete, why should any payments be made to the government as rental or royalty? Such an act would admit that the real ownership was in some one else-in this case the Mexican government. If registry under the new law was more than a formality for the completion of the public records, it also might cloud the title to lands in full possession. The new registry, it was maintained, would in itself pass the actual title to the government or at least put the companies within the terms of the clause of the Con- 
stitution that made their properties Mexican in the sense that they could not appeal to their home governments for protection. If the owners refused to comply with the law, their properties were forfeited. If they did comply with the law, the result was the same.

Against these actions by the Mexican government, the United States, Great Britain, Holland, and France protested. The American note, dated April 2, 1918, declared that the Government of the United States would not object to fair taxation nor to taking of the property of its citizens for true public use if proper compensation were made, but it could not "acquiesce in any procedure ostensibly or nominally in the form of taxation or the exercise of eminent domain, but really resulting in the confiscation of private property and arbitrary deprivation of vested rights." The proposed taxes, in themselves, were so heavy as to indicate a trend in the direction of confiscation, but the more serious question was the apparent attempt of the decree to separate ownership of the surface from ownership of the petroleum resources under the surface of the land. It was pointed out that the taking of the rights in question would be accomplished by executive action, without judicial process and apparently without any proof that the "separation of mineral rights from surface rights is a matter of public utility upon which the right of expropriation depends." The note concluded:

In the absence of the establishment of any procedure looking to the prevention of spoliation of American citizens and in the absence of any assurance, were such procedure established, that it would not uphold in defiance of international law and justice 
the arbitrary confiscations of Mexican authorities, it becomes the function of the Government of the United States most earnestly and respectfully to call the attention of the Mexican Government to the necessity which may arise to impel it to protect the property of its citizens in Mexico divested or injuriously affected by the decree above cited.

To this protest no answer was sent. On May 18, however, it was announced that the decree of February 19 would not take effect until July 31, 1918. On July 8 another decree postponed action until August 15. The United States again protested, and on August 14 Carranza issued another decree eliminating the necessity of title regulation. The "rentals and royalties" provision, however, was not recalled in principle, and right to possession was conditional on recognition of government ownership.

What the position of the property owners was still remained uncertain when the attack was renewed from another direction. A drilling license for working oil properties has frequently been required as a police measure. This requirement was now combined with other Mexican legislation for use for a broader purpose. The Constitution declared that concessions for oil development could be made "only on condition that said resources be regularly developed, and on the further condition that the legal provisions be observed." The situation threatened was: Develop your lands or forfeit them. You cannot develop your lands without a drilling license. The license will be granted you only on condition that you recognize the standard the government imposes as a condition for holding and operating your 


\section{MEXICO AND ITS RECONSTRUCTION}

lands. Obviously this might be used as a means to dispossess the present owners.

Carranza, meanwhile, had given a reply to the protests of foreign powers against his decrees, denying the right of complaint and declaring that if foreigners had grievances, the Mexican courts were open to them. The oil interests joined in taking action for legal protection under Mexican law. The Mexican Congress was called to consider what should be done. Though the attitude of the government was officially unchanged, assurances were received in May, 1919, that no law enacted by the Congress in the proposed petroleum code would have retroactive effect. The American Department of State was advised that the new oil law would not nationalize oil properties acquired before May 1, 1917.

This assurance seemed to indicate that the road was now open toward an amicable adjustment of the petroleum difficulties, but subsequent developments did not show that to be the case. The various notes exchanged indicated that the Mexican government still sought recognition of national ownership of the petroleum resources. Direct steps to this end having been declared unacceptable by the United States, the same result was sought through further provisions concerning denouncements of property, taking out of drilling permits, and decrees concerning the so-called Federal Zone. ${ }^{10}$

9 The decrees referred to above were discussed in various issues of the Commercial and Financial Chronicle, New York, during 1917-19.

${ }^{10}$ See detail of this correspondence in "The Mexican Oil Controversy," n. p., October, 1920. 
Later, under the Obregón government, moves against the petroleum interests were made through the taxing power, under a decree to become effective July 1, 1921. The alleged purposes of the new regulation were to stabilize the world's oil market, to conserve the national resources, and to furnish funds with which the government could again begin payment of interest on the national debt. The rates of taxation were so high that they were alleged to be confiscatory.

As the negotiations for recognition of the Obregón government proceeded this question became bound up with the older controversy. The oil producing interests protested to the United States government that recognition should not be granted unless the alleged confiscatory program of the Mexican government, under whatever guise presented, should be abandoned.

On June 7, 1921, Secretary of State Hughes issued a statement outlining the fundamental position of the United States. It pointed out that the matter at issue was much more important than the question of the recognition of any particular government in Mexico and declared: ${ }^{11}$

The fundamental question which confronts the Government of the United States in considering its relations with Mexico is the safeguarding of property rights against confiscation. Mexico is free to adopt any policy which she pleases with respect to her public lands, but she is not free to destroy without compensation valid titles which have been obtained by American citizens under Mexican laws. A confiscatory policy strikes not only at the interests of particular individuals, but at the founda-

${ }^{11}$ New York Times, June 8, 1921. 


\section{MEXICO AND ITS RECONSTRUCTION}

tions of international intercourse, for it is only on the basis of the security of property, validly possessed under the laws existing at the time of its acquisition, that commercial transactions between the peoples of two countries and the conduct of activities in helpful coöperation are possible. . . .

This question is vital because of the provisions inserted in the Mexican Constitution promulgated in 191\%. If these provisions are to be put into effect retroactively, the properties of American citizens will be confiscated on a great scale. This would constitute an international wrong of the gravest character and this Government could not submit to its accomplishment. If it be said that this wrong is not intended, and that the Constitution of Mexico of 1917 will not be construed to permit, or enforced so as to effect, confiscation, then it is important that this should be made clear by guarantees in proper form. The provisions of the Constitution and the Executive decrees which have been formulated with confiscatory purposes make it obvionsly necessary that the purposes of Mexico should be definitely set forth.

The oil dispute is not only important in itself, but because it reveals the general attitude the governments that have followed the revolution have shown toward foreigners and foreign capital. The provisions concerning general land ownership might be given retroactive effect, it appears, if the government were allowed to establish that standard as to any other sort of property. The holding of land might be made conditional on the payment of taxes in the forms of "rents" and "royalties." A new registry law might be framed in a way to cut off the right of the foreign owner to appeal to his home government or the same end might be reached by the requirement of a license to operate the land. Manufacturing enterprises and public utilities might be in- 
cluded within the scope of similar regulations, all forming a part of a comprehensive "nationalization program."

In fact, if the Mexican government were allowed to enforce retroactive laws affecting certain property rights of foreigners, there seems to be no reason why the application could not be logically extended to the entire field of their privileges. If foreigners could be required, as an arbitrary condition of continuing to operate their properties, to divorce themselves from the privilege of appealing to their own governments for the protection of their property rights, they might be required to surrender all right of appeal on any ground in return for a grant of the same privilege.

The Constitution contains still another clause that seems to carry the possibility of abuse in relation to the personal and property rights of foreigners, though it has not appeared prominently in the discussions thus far raised. The right to live in Mexico is subordinated to the powers of the executive "in so far as relates to the limitations imposed by law in regard to emigration, immigration, and the public health of the country, or in regard to undesirable foreigners resident in the country," ${ }^{12}$ and "the Executive shall have the exclusive right to expel from the Republic forthwith, and without judicial process, any foreigner whose presence he may deem inexpedient." 13

Similar clauses are not unknown in the legislation of other countries and the exercise, within reasonable 
limits, of such a right is not properly questioned. If, however, the executive should undertake in pursuance of an anti-foreign program, to make continued residence conditional on the surrender of the rights, which the foreigner enjoys under international law, such action could not fail to arouse protest on the part of the states whose nationals were involved. The exercise of the "exclusive" right of the executive to expel "without judicial process" any resident foreigner whose presence in the country "he may deem inexpedient" or "undesirable" is one, the exercise of which can not be arbitrary. If it were so, the property and personal rights of those whom Mexico has "virtually invited to spend their wealth and energy within its borders" ${ }^{14}$ would practically be beyond the effective protection of the law. No self-respecting country could permit itself to accept such a standard.

The home governments of all foreigners living in Mexico can not escape the responsibility of doing all that is allowed under international law to assure that their rights in the republic shall be recognized and preserved. The law under which they live must be one that establishes equitable standards, not one which, while having regularity of form, denies them the substance of their rights. Broadly considered the firm insistence on such a standard is not a policy lacking in friendliness for Mexico. To fail to insist on such treatment for foreigners would be to encourage the creation of conditions in Mexico that would bring with them a serious menace to its independence.

14 The words quoted are in the American note of April 2, 1918. 
At bottom, of course, the protection of the lives of its citizens is one of the first duties of every state, a duty that does not cease at the boundary. Abroad protection should be given not only in normal times, when, in fact, it will seldom be necessary to call for it, but, so far as circumstances permit, during periods when the countries to which the citizens have gone to live are suffering invasion or are torn by civil war. The outrages practiced on the local population may arouse active sympathy abroad, resulting in extreme cases in intervention by the foreign government in defense of the interests of general humanity, but long before that point is reached a country must feel the call to protect its own citizens resident in foreign lands, when their rights are violated.

It can not be claimed, of course, that as soon as public order is disturbed in a country foreign governments have a right at once to resort to armed intervention to protect their citizens, but in every case it is a national duty to make all governments and all parties to conflicts within them understand that prompt and full reparation for wrongful damages will be expected. Up to what point protest and redress can properly be relied upon, and when more forceful measures must be resorted to can be determined by no definite rule. The character of the disturbed populations, the nature of the violations, their long continuance, the prospect of early adjustment of public order, and an indefinite number of political considerations all influence the decisions that will be taken. No country is under the obligation to allow the abuses to continue indefinitely. At some point the duty to respect technical foreign sovereignty be- 


\section{MEXICO AND ITS RECONSTRUCTION}

comes less insistent than the duty to defend the rights of the home government and its citizens.

In the opinion of large numbers of people who have watched developments in Mexico during the revolution the time has long passed when foreign countries should content themselves with protests. The stronger foreign governments, during much of the period of the revolution, have had their attentions and energies occupied elsewhere. On other occasions they have frequently shown themselves unwilling to act when the steps they might take against a weak state could be attributed to selfish interests. It can not fail to be clear, however, that with the cessation of the larger hostilities in Europe and the continuance of chaotic conditions in Mexico the demand for the respect of human rights in Mexico will become more insistent.

What the actual situation of the foreigner is in Mexico, it is hard to state in a comprehensive way. Reports are contradictory and incomplete. The majority of those foreigners who lived in the republic ten years ago have probably left the country. There is no doubt, however, that the experiences they have endured during the past decade have been harrowing in many cases, and ones which in other times and circumstances would have brought foreign intervention.

The sufferings of American residents have been greater than those of other foreign colonies because Americans have been present in larger numbers; they have been residents, to a large degree, of the more disturbed regions and, at least in some instances, they have been the subject of a particular dislike. Nevertheless, 
what has happened in their cases may be cited as an illustration of the sorts of wrongs that many foreigners have had to endure.

The list is too long to be recounted at length. Its details are often of too refined a brutality to allow public discussion. They are eloquent testimony that a government that was unable to stop the mounting total of crimes within its territory for practically a decade, let a large part of its people get out of hand and was apparently unable to reduce them to control. The details of what happened in the country are portrayed in letters, telegrams, memorials, and records of personal experience, speeches presented in Congress and testimony before Congressional committees. The record is revolting. As reported to the Congress of the United States, it includes robbery, extortion, holding for ransom, plunder, burning of property without cause, murder by various means, including throat-cutting, disemboweling, beheading, and mutilation. It includes forcing severely wounded women to cook for soldiers, and outrage of wives and children in the presence of wounded or bound husbands and parents. ${ }^{15}$

Nor is it to be supposed that the wrongs against for-

${ }^{15}$ See, for speeches detailing wrongs of the sorts cited, Congressional Record, vol. 51, part 4, p. 3743, February 21, 1914, and part 5, p. 4512, March 9, 1914. Detailed testimony concerning conditions in Mexico as they affect the rights of foreigners is published in Investigation of Mexican Affairs, Hearing before a Sub-committee of the Committee on Foreign Relations, United States Senate, 66th Congress, 1st Session, pursuant to S. Res. 106, parts 1-3, pp. 1-677. The violation of personal rights is discussed, especially at pages $370-402$. 
eigners have been confined to the earlier period of the revolution and were a result only of the first flush of passion which the conflict aroused. On the contrary, the list of American citizens killed in Mexico between 1911 and the middle of 1919, published by the Department of State in response to an inquiry by the United States Senate, shows a series of rising totals. ${ }^{16}$ Henry Fletcher, American Ambassador to Mexico, testified in August, 1919, that during 1918 and 1919, 51 Americans had been killed in Mexico. During that time he had not been informed of one prosecution by the Mexican government for these crimes. ${ }^{17}$

No fair-minded person believes that such acts are attributable to the better class of Mexican citizens or that they condone such abuses. They deplore them as much as do any civilized people. But no government can escape the responsibility for allowing conditions to continue indefinitely under which such crimes can occur, and upon the best citizens of Mexico falls the duty to join hands to bring their fatherland again into the control of those who can maintain public order within its territory. Upon their rising to that high opportunity may depend the future of independent Mexico.

16 "Claims Against Mexico," Senate Document 67, 66th Congress, 1 st Session, July 31, 1919.

${ }^{17}$ The Independent, August 9, 1919, p. 172. 


\section{CHAPTER XX}

\section{THE TROUBLESOME BORDER}

WHEN one American speaks to another of "the border," there is no doubt what border is meant. When the frontier problem is under discussion, it is always the Mexican frontier. There is no Canadian border in the sense in which there is a Mexican border; on that side there is a boundary line, but it has no problems. As an artificial barrier to free passage of trade it is troublesome to individuals on both sides of the line and looked upon as a necessary nuisance. It is not an imaginary wall separating two clashing sets of national interests, a protection against the aggressions of a suspected neighbor before whose courts a man from beyond the boundary is not de facto equal before the law.

Why is it that our southern boundary has been and is a problem, a "frontier" with all the sinister connotations of the word, while our northern boundary is not? The answer touches many of the reasons for the lack of good understanding between America and its southern neighbor.

The ill-feeling along the frontier is partly explained by history; it is the survival of the hate aroused by the Mexican War, but this is, at most, only the capstone of a group of elements, the one that claims first attention and lives longest in the memory, without being the most fundamental. Educated Mexicans still avoid reference 
to " 49 " or discuss it as a year, the events of which are a source of national grief and a warning of what may again be expected. The agents of Germany in the World War thought the feeling still of sufficient potency to justify holding out before Mexico the possibility of a revanche. It may be doubted whether this sentiment runs as deeply as some would have us believe. Mexico does remember that the United States was her enemy in the middle of the nineteenth century, more keenly than she remembers the service rendered her by the same nation some two decades later, but she would not do so if there were not other elements contributing to her regret for losing the little-settled and less-governed wilderness that she lost in her war with the United States.

The underlying causes of Mexican-American distrust fall into three overlapping groups-human, physical, and governmental. Of the first the most important is the contrast of race. The attitude of the people of the United States toward the less-developed races has never been a friendly one. It has lacked the tolerance which the British have developed for the peoples with whom they have come into contact.

The problem has been more difficult in America, because it has been a closer one. Except in the Philippines, the less-developed peoples with whom the United States has had to deal have been within its body politic or upon its edges. There has not been any clear-cut class distinction, recognized by both sides, such as has established the relation of "superior" and "inferior" in most of the cases where Anglo-Saxon populations have come into contact with non-Europeans outside of Amer- 
ica. Those who have come into contact with Mexican civilization along the border, too, have been, to a large extent, that portion of the American people who have had closest contact with the negro papulation of the republic and regard them, and to hardly a less degree any colored or mixed blood people, as unquestionably inferior. To the Mexican this attitude is a constant irritation.

Contrast in language and civilization accentuates frontier problems. On our northern boundary there is neither. Immigrants pass in both directions hardly. conscious that the boundary exists. The flowing into Canada of an agricultural population from the United States occurred without clash. A similar movement could not take place from the United States to Mexico. To be sure, there is a border belt in which there is a population to some degree bi-lingual and large numbers of Mexicans, especially since the revolution, have sought an opportunity for a more secure livelihood across the border. But the average Mexican in the United States remains a foreigner in habits of life. For him, on account of a combination of elements including race, lack of education, and lack of resources, it is hard to become a part of the life of the new community in which he finds himself. In many cases he does not wish to do so.

Americans of the border states of Mexico also seldom identify themselves with the local life. They keep their American citizenship; they may be engaged in the exploitation of mines, lumber, or other natural resources, but they are representative of a "foreign interest." Even though they become landowners, they continue to 


\section{MEXICO AND ITS RECONSTRUCTION}

look upon themselves as foreigners and to be looked upon as foreigners by the native population.

It is common to hear Americans speak of the United States as the melting pot. They are proud of the adaptability of the American. They take a certain pride in the easy way in which the European populations have been blended into the body politic. They have not shown the same willingness or ability to absorb nonEuropean stocks or to be absorbed by them.

The American people have declared by law that they will not allow an opportunity to arise under which Chinese may be absorbed, and the Japanese are excluded by law plus administrative regulation. They have refused to absorb the aboriginal Americans and alliance with the imported non-European stocks brings social ostracism. Mexicans in the United States hardly fare better. If they are of Spanish ancestry, that fact is emphasized and any prejudice against them disappears - they are then Europeans. If they are not, they suffer the same discrimination as other mixed blood or non-European peoples. The same unyielding prejudice follows the American settler in Mexico. $\mathrm{He}$ is proud to remain a foreigner, and he looks with disfavor on any alliance of his sons or daughters with any Mexican not of pure European ancestry.

The physical features of the border have contributed to the lack of good understanding between Mexico and the United States. They, of course, largely determined the settlement or the lack of settlement of the region. The broad dry strip of territory stretching northward from the Gulf of Mexico toward the mouth of the Colo:- 
rado River seemed, until the coming of the railroads, to be the perfect boundary, which theorists have imagined for separating nations. It was almost a desert. It was not valuable land. A sparse population was all it. could support where it could support any at all. Small land-ownership was unthinkable.

Mexican efforts to control this region had always been futile. They never had effective control over the region north of the Rio Grande before the war with the United States, and it was long after the middle of the last century before any true policing of the district south of it was attempted. Even up to the time of the present revolution the native tribes of her northwest disputed her authority with fair success.

Effective American control extended southwestward more rapidly than Mexican governmental authority came to meet it, but it would be easy to overemphasize the fact. At all times it is difficult to police a sparsely settled, arid country, such as the lands along the Mexican border were a generation ago. They continued up to our own day to be a region wherein things were done with impunity-on both sides-that neither government would approve, a territory in which each man was, to a large degree, a law unto himself. It was a place where individualism thrived, where self-help was at a premium, and where the strong one was too often the judge of the rights of the weak.

A region like the Mexican border produced and drew to itself from other regions a not too gentle population. The only life that could be lived there was one on which adventurous spirits thrived. Those who had yentured 
too much in the communities of their birth came to add their bit to keep life on the border from becoming dull. If they were "wanted back home," they had a tendency to step across the border, whence they might make themselves even more a subject of anxiety for their home governments.

Such a community, as it grew, developed a rough and ready character not inconsistent with respect for its own, but having little conscience about the rights of those across the border. The records of the foreign relations of the United States and Mexico for the '70s, '80s and '90s of the past century are interesting, if not always pleasant reading. They are by no means records of a civilization of which either Mexicans or Americans can be uniformly proud. Raids, violations of sovereignty, contraband trade, corruption of officials, murders, miscarriage of justice, stimulation of national antipathy by newspapers, which baited each other across the border-the record is full of evidence that the friction in Mexican-American relations was so great that a bursting forth into flame was a possibility for years and doubtless would have occurred frequently but for the efforts of the governments to calm the local discontent.

In the period before the Diaz régime a stream of complaints of lawlessness went from the border to Washington and Mexico. While the revolution was in progress the partisans of Lerdo de Tejada operated along the border and were popular in certain districts of Texas. At times they allowed United States troops freedom to operate on both sides of the river to put 
down raiders. ${ }^{1}$ At others the local authorities were completely out of hand and no attempt was made by the Mexicans to control them nor was a willingness evidenced to let the United States exercise effective measures to check wrongdoing. On the north side of the river the state authorities showed a disposition to act independently when the central government refused to give life and property protection from Mexican aggressions. In 1874, Governor Coke of Texas took affairs into his own hands and ordered the forces under his control to pursue cattle thieves "both on this side of the river and on the other," and when called to account by Secretary Fish, refused to modify his orders. ${ }^{2}$ There were several invasions by Texas troops in the following year.

During this period the offenses against order were doubtless more frequent from the Mexican than from the American side. Indeed, on May 20, 1875, Secretary of State Fish made the statement that during the four years previous there had been none from the United States and challenged proof to the contrary. The statement was handed to the Mexican minister of foreign affairs, who promised to examine the evidence in his office, but made no reply. ${ }^{3}$

General Diaz came into power November 29, 1876. The United States refused to recognize his government,

${ }^{1}$ Shafter to the Assistant Attorney General, May 10, 1877, House Document 13, 45th Congress, 1st Session, p. 147.

${ }^{2}$ In a memorandum left by Mariscal with Evarts June 7, 1877, published in ibid., p. 61 .

${ }^{3}$ Foster to Evarts, June 28, 1877, in ibid., p. 30. 
one reason being that there was "some doubt" whether his government "possessed the ability and the disposition to check the raids and depredations upon American property in the vicinity of the Rio Grande." In the first years of the Diaz régime the clashes continued frequent. Settlement was spreading into the southwest and the plunderable property was increasing in value, making the temptation to the lawless greater and the demand for redress more insistent. For several years conditions seemed to be growing steadily worse."

The border was a "free for all" region in these years. It is impossible to make distinction between American and Mexican outrages. They were frequent on both sides of the line, and it was often difficult to tell whether the guilty were Mexicans or Americans. The population of Texas exaggerated Mexican faults to emphasize their claims for damages and to induce the government to place more troops on the border, from the provisioning of which the local population might prosper. That this was true was admitted by the American Secretary of State. ${ }^{5}$ State and national control of the border later stiffened and wrongs committed against Mexicans north of the border decreased in number.

The Diaz administration, then striving to establish itself within the country and among the family of

${ }^{4}$ A gloomy review by Minister J. W. Foster of the condition of Americans in Mexico and of border relations covering a period of more than five years is found in Papers Relating to the Foreign Relations of the United States, 1879, p. 755 et seq.

${ }^{5}$ House Document 13, 45th Congress, 1st Session, Foster to Evarts, July 24, 1877, in a Memorandum of the Mexican Minister of Foreign Affairs, p. 38. 
nations, did not consider of slight importance the crossing of the border by American troops and, while anxious to secure the friendship of the United States, was unwilling to do anything that seemed to cloud what was declared to be a principle of national sovereignty. In taking this position the government received the hearty support of the press. ${ }^{6} \quad$ The administration insisted that in the later '70s raids were becoming less frequent." When an instance of violation of American territory by Mexicans was brought to his attention, President Diaz gave complete disavowal and promised prompt investigation, reparation, and punishment. ${ }^{8} \mathrm{He}$ withdrew to the interior generals toward whom the United States had expressed distrust and whom it appears Diaz himself could not fully control. ${ }^{9} \quad$ He sought a similar standard of action from the United States.

But, for the United States, evidences of the Mexican desire to relieve the tense situation on the border were not enough. The Mexican generals who were sent to replace those who had shown themselves in sympathy with border lawlessness were given a cool reception by the Mexican state and local officials and their authority was not recognized. Between October, 1876, and March, 1877, it was reported Indian marauders from Mexico killed $\mathbf{1 7}$ men and the arms and horses taken from the

${ }^{6}$ See collection of newspaper comments in ibid., p. 21 et seq.

${ }^{7}$ Memorandum by Mexican Minister of Foreign Affairs forwarded to Secretary Evarts by Minister Foster, July 24, 1877, in ibid., p. 40.

${ }^{8}$ Foster to Evarts, July 9, 1877, ibid., p. 34.

${ }^{\circ}$ Foster to Fish, March 3, 1877, ibid., p. 3. 
murdered men were openly offered for sale in Mexico. Large numbers of horses and cattle were driven from Texas into Mexico. In one instance a raiding party was followed over 150 miles into the country to their camp "where nearly 100 of the cattle had been slaughtered and beef was found drying." The marauders found a refuge in the Mexican towns when pursued and sold their plunder there. In some cases American troops crossed the border and punished the offenders. The United States military authorities declared "that the only way to check these atrocities is to follow the delinquents into Mexico and there attack them in their lairs. ${ }^{10}$ The Government of the United States was coming to feel that if the outrages were persisted in, it would adopt this policy with or without the consent or acquiescence of Mexico.

Matters came to a head on June 1, 1877, when the Secretary of War wrote General Sherman instructing him to notify General Ord, commanding the border forces, to ask the coöperation of the Mexicans in bringing an end to disorder and to inform them that while the President was anxious to avoid giving offense, "the invasion of our territory by armed and organized bodies of thieves and robbers" could "not be longer endured." General Ord was informed that if Mexico continued to neglect to suppress such bands, the duty to do so would rest upon the United States, and the duty would be performed "even if its performance should render neces-

${ }^{10}$ Evarts to Foster, ibid., p. 4, citing a report of P. H. Sheridan which refers to an opinion of Colonel Shafter. 
sary the occasional crossing of the border by our troops." General Ord was informed that he was "at liberty, in the use of his own discretion, when in pursuit of a band of marauders, and when his troops are either in sight of them or upon a fresh trail, to follow them across the Rio Grande, and to overtake and punish them, as well as retake stolen property. ..." 11

This was the famous Ord order. It was hardly issued before the United States Government had to complain that Diaz troops had driven a band of Lerdists across the river into Texas, where they were attacked and dispersed. American officers asked whether they should cross to punish the offending forces. They were instructed not to cross, but a prompt disavowal was demanded.

The Ord order meanwhile created a widespread protest in Mexico, and under date of June 18, 1877, the Mexican government ordered its forces to resist any crossing and to "repel force by force, should the invasion take place." ${ }^{12}$ In August a band of Mexicans raided the county seat of Starr County, Texas. American forces followed them to the river and the Governor of Texas demanded the extradition of the criminals, a demand supported by the United States Government. Mexico now made a sérious effort at reparation, but the border officials had little respect for the demand made upon them. Some of the raiders were arrested and surrendered, although the extradition treaty did not de-

${ }^{11}$ Secretary of War to General Sherman, June 1, 1877, ibid., p. 14 .

${ }^{12}$ Ibid., p. 18 et seq. 


\section{MEXICO AND ITS RECONSTRUCTION}

mand it. The local authorities refused to surrender the rest. An American force crossed the border in October in pursuit of marauding Indians, but, on the approach of Mexican troops, retired.

By this time the Ord order had been modified on assurance that Diaz recognized the gravity of the situation and would send to the border a prudent general with an adequate force. ${ }^{13}$ General Ord was instructed to coöperate with the Mexican general and to cross the border only in an aggravated case. The instruction did not stop the crossings. A proposal to allow reciprocal privilege met a non-committal answer from the Mexican commander. The officers had received commands not to attack the United States troops, but to "see" them cross the border. ${ }^{14}$ Later the objectionable Ord order was revoked to the great satisfaction of Mexico. ${ }^{15}$

In the meantime Minister Foster, on April 24, 1877, recommended that recognition be given Diaz by the United States, in the belief that this might strengthen the hands of the government. ${ }^{16}$ On March 23, 1878, though conditions in Mexico were still unsatisfactory, the President instructed the American Minister that the Diaz government was formally recognized. ${ }^{17}$ Later in the year Mexico was still unable to repress raids and the United States again declared it would not stand

${ }^{13}$ Under date of June 9, 1877, ibid., p. 101.

${ }^{14}$ Ibid., pp. 45-240, passim.

${ }_{15}$ Papers Relating to the Foreign Relations of the United States, 1880-1, p. 735.

${ }^{16}$ Foster to Evarts, April 24, 1877, op. cit., p. 6.

${ }^{17}$ Papers Relating to the Foreign Relations of the United States, 1878, pp: 543 and 573. 
quietly by while the criminals were allowed to flee into Mexico, there to have refuge from just punishment. "When Mexico will pursue the marauders, the United States will be glad to stop doing so at its own boundary," but cases in which Mexican troops were fed with the cattle yielded by border raids, the commanding officer knowing of the theft, protecting the raiders, and furnishing them with arms, were unbearable. If Mexico could not, or would not, punish such acts, the United States, it was intimated, would have to, whatever happened to the theory of sovereignty in the meantime. ${ }^{18}$

While these events were taking place, the governments were in negotiation to try to secure some basis for an agreement by which the threatening clash could be avoided. Finally, in 1881, a limited reciprocal right of crossing was arranged, but one, unfortunately, that it proved impossible to make permanent. Though the agreement did not satisfy either side, it helped to bridge over what proved to be the period of greatest danger. Both sides continued to report atrocious happenings, but there developed a greater willingness to admit that the problem was a mutual one in which the elimination of the cause was at least as important as the maintenance of the theoretic rights of sovereignty.

General Polk, commanding the Department of the Missouri in the early ' $80 \mathrm{~s}$, declared it beyond question "that bands of thieves infest the whole southwest and plunder citizens in both countries." "They ... . are sometimes occupied in smuggling, at others in steal-

${ }^{18}$ Ibid., p. 612. 


\section{MEXICO AND ITS RECONSTRUCTION}

ing." ${ }^{10}$ A few years later a similar complaint was made by Mexico. Her minister of foreign affairs complained that American Indians crossed the border, committed depredations, and then fled across the protecting boundary. It was claimed by the Governor of Chihuahua that in less than one month more than 60 persons had been killed by savages in that state alone. "It is high time," concludes the Minister of Foreign Affairs, "for the honor of the age in which we live, for the honor of two powerful neighboring Republics, for the sake of the friendship that happily exists between them, . . . that a stop be put to [these] frightful scenes, ..." ${ }^{20}$ As the Diaz government succeeded in establishing itself and as the settlement and better policing of the American side of the river progressed, the danger of a breach between the two governments lessened.

The source of complaint gradually shifted to the westward and, as exploitation of the resources of the border states progressed, especially after the railroads crossed the boundary, southward. The border problem broadened and became one involving the general protection of the life and property of foreigners. The violation of sovereignty by crossing the frontier in one direction or the other was less common and the rights of resident aliens came more frequently under discussion. Since the economic development of the country was spreading from north to south, it was natural that the disputes should more frequently involve the rights of United States citizens in Mexico than the reverse.

${ }^{19}$ Ibid., 1881, p. 756.

${ }^{20}$ Ibid., 1883-4, p. 680 et seq. 
The border itself was still a source of irritation, but a less insistent one. At times each government showed a disposition to blame the other or to explain its own shortcomings by reference to peculiar disadvantages under which its military forces worked. By 1892, though the military measures taken had "sufficed to make ... lawless attempts very dangerous and unprofitable to the criminal," who might or might not operate under a political disguise, there was still enough marauding to keep the discussion warm. The Mexican Minister of Foreign Affairs and the American Secretary of State continued to complain to each other against raids by groups of bandits from across the border. The Mexican statesman asserted that when the bands crossed into Mexico they were beaten back toward the border across which they fled, taking refuge in the United States, whence they could again issue as soon as the vigilance of the Mexican troops relaxed or other favorable circumstances developed. Local sentiment along the border was still declared not to be against the bandits, as was shown by "culpable connivance or tolerance on the part of certain functionaries in Texas." More federal troops should be provided for keeping the peace. The American government replied that "the efforts of the United States Government to prevent these raids from its territory into Mexico seem to receive little cooperation ... from the Mexican side. . .." If Mexico would only keep a force on the south, such as the United States had on the north, all would be well. Mexico apparently found it inadvisable to attempt to maintain a force of such size as was suggested by her 
northern neighbor and the United States was indisposed to increase the number of its troops. It felt that the running down and punishment of the guilty was a better method of stamping out banditry than the adoption of extensive preventive measures.

On both sides the control of the marauders was rendered difficult by their methods of operation. A band might be collected in the United States, for example, with the intent of raiding Mexico, but it would cross the border casually at different points as individuals. Meeting at a rendezvous, the depredations would be committed, and the guilty would again disperse. The only time when the band could be met as a band, therefore, was when the wrongful acts were actually being committed.

The same circumstances surrounded raids from Mexico against the United States. In the latter country, at least, there was the added difficulty that the pursuit of the wrongdoers was a duty of the civil authorities of the government or of Texas and the troops could only aid the United States marshals as a part of their posse. Coöperation by allowing a reciprocal crossing of the boundary in pursuit of wrongdoers seemed an obviously desirable privilege and one that Mexico now seemed disposed to grant, while the United States held back. For both countries this was a curious reversal of position compared to the early '80s. The United States felt that the increase of settlement made the problems, which would arise under such conditions, more serious than formerly. The military authorities in charge of border affairs did not favor a renewal of the arrangement. It 
did prove possible, however, to arrange for coöperation in notifying the forces of each country of possible raids and to station the troops in such a way that the fords could be more effectively policed. ${ }^{21}$ In at least one case a reciprocal right of crossing was arranged. ${ }^{22}$

Impartially considered, it is plain that in the border incidents the shortcomings did not lie wholly on one side. At times each country found itself drawn into defending persons because of their nationality who deserved no protection from any one. Sometimes the rules of international law, which were intended to promote good relations among nations, seemed to be the chief cause of entanglements. For example, it was not always easy to differentiate border raids from "revolutions" or either of these from the Indian depredations, which even down to our own day have continued to be a source of disturbance along the boundary. In the discussions of pursuit of wrongdoers across the border there has been a conspicuous lack of willingness to recognize the fact that under the conditions that have existed it would be better for both parties to place considerations of public order and justice above insistence upon scrupulous observance of the "rights of sovereignty."

Where settlement is sparse, policing on account of great distances is difficult, and the boundary itself often hard to locate, opportunities for the lawless flourish and shuttling back and forth across an imaginary line is an easy way to defy the law. The local population on both sides of the border frequently looks upon the bandit

21 These facts are summarized from ibid., 1893, vol. 1, pp. 429-55. ${ }^{22}$ Ibid., 1896, p. 438. 
as a semi-hero, if he confines his operations to the other side of the boundary. Evidence of guilt is hard to secure partly because of this sympathy and partly because of fear of retaliation by friends of the accused. Dissatisfaction is sure to result, especially when one country does not or cannot maintain as efficient a police patrol as does its neighbor. Add to these elements a roving population, one that gives only nominal respect to either sovereignty, such as the border Indian tribes were, and trouble is very likely to rise. If either side yields to the temptation to enlist these aborigines in its own military forces, either as guides or as soldiers, as both Mexico and the United States formerly did, clash is almost unavoidable. Looked at long after the event, it is not remarkable that there were such acrid interchanges between the two governments. It is to the credit of both that wiser counsels prevailed and that the many technical causes of war were kept in their proper perspective.

The meticulous insistence on respect for technical rights under international law, which some border incidents involved, makes the history of some of them amusing as well as illustrative of frontier conditions and psychology. One of these was the much-discussed case of Jesus García arising in 1896.

The incident arose in Nogales, a town located on both sides of the border, with a street running diagonally through it which crosses the boundary line. García was a powerful man described as "a low-down desperado," who was at the time of the incident "on a general drunk," "bulldozing the saloons." $\mathrm{He}$ and another Mexican came out of a saloon on the American side of the line 
and began to fight. An American officer ran toward them and arrested them on the American side of the boundary. García resisted. The officer called for assistance and another American ran from the Mexican side of the line and collided with García, who fell with his head and a small part of his body on Mexican territory. No blow was struck. García was then marched toward the jail and on again resisting was struck with a leather walking cane to quiet him. No blood was drawn.

As reported to the Mexican government and made the basis of diplomatic protest, this case had a decidedly different character. Two Americans, one an officer, crossed into Mexican territory to arrest García. The civilian knocked him down and the officer beat him while prostrate. They then dragged him across the line into Arizona, assisted by another American civilian. On the way to the prison the Mexican was again subjected to a cruel beating.

That such an affair should be raised to the dignity of an international incident would seem ridiculous and impossible if the high state of feeling and the willingness to twist evidence resulting therefrom were not realized..$^{23}$ The affair was finally patched up through acceptance by the Mexican authorities of the statement that no invasion of Mexican territory was contemplated and the declaration that in the opinion of the United States none had occurred. ${ }^{24}$

${ }^{23}$ Ibid., 1893, vol. 1, p. 457, also ibid., 1896, pp. 439, 448, 449,454 .

${ }^{24} \mathrm{~A}$ review of the various incidents which kept feeling aroused along the border is obtainable in Papers Relating to the Foreign 
The opening years of the nineteenth century, during which the Diaz régime was reaping the reward of its efforts to establish order and induce the economic development of the country, brought the period of most cordial relations between Mexico and the United States. The border problem was not at an end, but it was active only in Arizona and New Mexico and even there involved not so much raids across the boundary as the prevention of the purchase in the border towns of arms and ammunition, which were later used by the Indians against American citizens living south of the border. The attitude of the local authorities in the Mexican northwest toward American settlers also continued to be a matter of complaint. ${ }^{25}$ Both governments were anxious to do all in their power to remove the reasons for friction.

The Yaqui Indians, against whose acts the most numerous protests were made, are a Sonora tribe, about

Relations of the United States. Some of the more important disputes illustrating phases of the border problem are found at the following points: 1878, p. 679, illustrating "revolutionary" activity; 1888, vol. 2, p. 1176, illustrating border kidnapping; 1893, vol. 1, p. 468 , illustrating difficulty of securing evidence as to raiders; 1895, pp. 997-1013, illustrating position of refugees guilty of embezzlement; 1897, pp. 372 and 405, illustrating claims for damages caused by disturbance of public order. What is a political act?, also ibid., 1898, pp. 491-510; 1899, p. 499, illustrating unwillingness to surrender citizens to justice of another country; 1904, pp. 462-72, illustrating the prejudices of lower Mexican courts, and ibid., pp. 473-81, illustrating attitude of Texas authorities toward Mexican delinquents.

${ }^{25}$ Correspondence illustrating both phases of the problem is found in ibid., 1905, p. 639 et seq. 
whose wrongs and wrongdoings much discussion has occurred in both Mexico and the United States. Part of the tribe were peaceful, but others were chronic troublemakers, who, as President Diaz once reminded the American Ambassador, were comparable to the Apaches with whom the United States had had so much difficulty. ${ }^{26}$ They were especially active against Americans. These, the most prominent foreigners engaged in exploitation of the country, they looked upon as disturbers of what they considered the immemorial privileges of the tribe. The Mexican government, at least the central government, did its best to punish the guilty, but it could not always rely upon the soldiers it sent to punish the Indian bands. It adopted the policy of taking arms and ammunition away from the Indians, thinking that would bring an end to the trouble. After 1903 the government deported to Yucatan and Quintana Roo many, Indians who had taken part in marauding. ${ }^{27}$ Others were sent to colonization enterprises in Sinaloa and still others set to work in convict gangs in Sonora. To those who were disposed to settle down to a peaceful life the government supplied farming implements, farm animals, and poultry in Sinaloa. ${ }^{28}$ The Indians, however, continued to cross into Arizona towns "to work," where they replenished their ammunition supplies and then returned to Mexico to start trouble again. The local au-

${ }^{26}$ Ibid., 1906, p. 1142.

${ }^{27}$ Accounts of transfer of parties of such Indians are found in ibid., p. 1134 et seq. The policy of the government toward the Yaquis, as described by Diaz, is outlined at p. 1141.

${ }^{28}$ Ibid., 1905, p. 648. 
thorities were instructed to furnish escorts to Americans when they went outside the settled districts. It does not appear that such protection was always given, and in some cases when proffered it was declined by Americans, especially by mining prospectors, who did not want to have their movements observed. ${ }^{29}$

In 1906 President Diaz asked whether the United States would not give its active coöperation to stop the Yaquis from getting supplies of arms in the way indicated. $^{30}$ To do so would make it possible to assure order in the northwest states, promote their development, protect the lives of American citizens, and help to eliminate the claims for damages against the government of Mexico. The President, of the United States promised to do what he could to help. In the following year the Secretary of the Interior asked the Governor of Arizona to put into effect again precautionary. measures to prevent smuggling of arms. This he did. Similar orders were issued by the Secretary of the Treasury to the Customs Collector at Nogales. In 1908 the United States government concentrated forces along the border to stop fleeing marauders from seeking refuge in American territory, ${ }^{31}$ thus assisting the Mexican troops to stamp out disorder.

In short, in the closing years of the Diaz régime there fwas cordial coöperation between the government of

${ }^{29} \mathrm{~A}$ number of incidents illustrating these conditions are described in ibid., p. 639 et seq.

${ }^{30}$ Ibid., 1906, p. 1149; see also ibid., 1907, p. 846 et seq.

31 Ibid., 1908, p. 604, quoting the Mexican Herald of September $17,1908$. 
Mexico and the United States for the elimination of the border problem. Possibility of friction still existed for reasons of a nature that it will be difficult to remove, but the old suspicion and animosity shared by large numbers of both peoples, which made the border a source of constant irritation for both, was rapidly passing. The border problem was less a problem than it had ever. been. American economic interests had spread southward far beyond the boundary, and Mexico realized and admitted her duty, under international law and the rules of comity, to give them full protection. Mexican interests had grown in the United States, not in the development of the economic resources of that country, for Mexico was still a non-industrial debtor nation and had no large amounts of capital seeking investment abroad, but through the realization that the two countries, which had such close geographical relations, had, in their foreign trade, an economic common interest that closely bound the fortunes of the one to the fortunes of the other.

The good feeling that existed between the two republics was illustrated by the expressions of appreciation that passed between them just before the close of the Diaz régime.

The American Ambassador, speaking at a luncheon of the American Colony in 1907, contrasted the Mexico of that day with the one he had first known. He declared: ${ }^{32}$

${ }^{32}$ Papers Relating to the Foreign Relations of the United States, 1907, p. 859 . 
Thirty-one years ago conditions in Mexico were such that in few places could a man be reasonably sure of his life, if there was the slightest cause for it to be taken. At that time the country was filled with banditti ... and little thought was given by the masses to anything other than unfriendly strife. .. The national finances, in $\mathbf{1 8 \% 6}$, were at the lowest possible ebb and even at the late date of 1902 the total revenue of the Republic was only $\$ 66,14 \%, 048$, while the revenue for the fiscal year just closed was $\$ 113,000,000$, leaving a surplus of near $\$ 20,000,000$ beyond all national requirements. . . The more than 30 years since $18 \% 6$ have brought revolution after revolution in Mexico, but not revolutions of the old kind. The revolutions of the past 30 years have been those of mind and of commercial industry... Thirty years ago there were practically no Americans in Mexico, and the few that were here, with now and then an exception, were here because they could not stay at home, and there was no American capital invested in the Republic. To-day what a different condition we find. . . There are in the Republic of Mexico something like 40,000 Americans, and the majority of them are honest and industrious people who would be a credit to any country. Their sphere of action covers practically every known occupation.

Secretary Elihu Root, the guest of honor at a banquet given by the Minister of Foreign Affairs, carried the statement further. He said: ${ }^{3 s}$

I suppose that the true object which should be held before every statesman is to deal with the questions of the present so that the spirit in which they are solved will commend itself to the generations of the future. . . . The Government of Mexico has attained that high standard of statesmanship to an extraordinary degree. It certainly has done so in its relations with the Government of the United States, and, as a result of the

${ }^{33}$ Ibid:, p. 867. 
reasonable and kindly way in which we have been treating each other for these past years, ... there has grown up and is continually developing between the people of the two countries a knowledge of each other, an appreciation of each other, a kindly feeling toward each other which makes for the perpetuity of good government in both countries and for the development of all the finer and better parts of citizenship in both countries.

Among the friendly declarations from the Mexican side that which touches best the old distrust and the new confidence between the two countries was perhaps that of Manuel Calero, President of the Chamber of Deputies, who said: ${ }^{34}$

That you once wronged, that, when burning political, economical, and humane problems beset you, the course of justice was momentarily hampered, we have not forgotten; we have not. But as the years rolled on you have won back, inch by inch your place in our affection; the intercourse every day closer and closer between your people and ours, stepping over the bounds set by race and tongue, has infused new life into this feeling of mutual good will and friendship, which tend to establish harmony of ideals and close similarity of destiny.

Two years later there occurred the first exchange of visits between the Presidents of the two republics and the first visit of an American President to Mexico. At that meeting, after President Diaz had spoken of the cultivation and maintenance of the cordial relations existing, President Taft in his reply took "occasion to pronounce the hearty sentiments of friendship and accord with which the American public regard the Mexican people." He declared, "The aims and ideals of 
our two nations are identical, their sympathy mutual and lasting, and the world has become assured of a vast neutral zone of peace, in which the controlling aspiration of either nation is individual human happiness." ${ }^{85}$

Few were they who realized upon what an insecure foundation the Diaz régime rested. Order had been so long established that even the majority of those well acquainted with local conditions had come to consider it as a matter of course and, in her foreign affairs, Mexico had come to enjoy a position of greater prestige than any other Latin-American state. Capital was flowing from abroad to develop her industries, interest on public obligations was being promptly met, there was a surplus in the public treasury that could be devoted to the improvement of the conditions of the country. There was no cloud on the international horizon. Relations with all foreign nations were friendly and with the United States, the country with which the republic is of necessity most closely associated in foreign affairs, relations were cordial. The two countries had greater confidence in each other than ever before. The wounds of the conflict of two generations before were healing, the irritations of border conflicts were at a minimum. Everything seemed to justify the hope that there had been created in North America an area within which peace internal and external was secure.

${ }^{35}$ Ibid., 1909, pp. 425-8. 


\section{CHAPTER XXI}

\section{MEXICAN-AMERICAN RELATIONS}

THE foreign relations of Mexico begin with the official recognition of her independence by the United States. The first representative of Mexico was sent to Washington. With the exception of the period of the Mexican War, the two countries have been at peace officially though differences of opinion have been frequent, acrid, and, at times, threatening. The list of subjects on which amicable adjustments have been arrived at is a long one and a credit to both. They have had frequent recourse to arbitration. In this way they have set the example to other nations, both before and after the foundation of the Hague Tribunal. They have settled the complaints of their citizens by Claims Commissions. After decisions have been definitely made by such Commissions there have been equitable adjustments, when they were called for by the discovery of new evidence. ${ }^{2}$ Boundary claims have been amicably adjusted. Jurisdiction over the shifting

${ }^{1}$ See discussion in Exposición de la secretaria de hacienda de los estados unidos mexicanos de 15 de enero . . Mexico, 1879, p. 46.

${ }^{2}$ See the discussion of the return to Mexico of money paid to the United States under decisions by the United States and Mexico Claims Commission after production of evidence showing the claims to be fraudulent, in Senate Report, 50th Congress, 2d Session, 1888-9, vol. 4, No. 2705, and in Papers Relating to the Foreign Relations of the United States, 1900-1, p. 781 et seq. (the Abra Silver Mine Company case), and in ibid., p. 483 (the Weil case). 
bancos, or shoals, of the Rio Grande has been arranged by friendly compromise. The Pious Funds dispute was taken to the Hague for settlement and the Chamizal controversy was turned over to arbitrators. Other instances might be cited. The old disputes have passed. They have all gone the same way. The new ones must follow them.

There are few in either country who realize the importance of Mexican-American relations to both countries. American relations will always be the chief element in Mexican foreign policy. That is a fundamental fact, no matter how unwelcome to certain classes in Mexico. Circumstances beyond the control of any government, the geographical position of the country, and the character of its natural resources make it so.

The necessary interrelations of the two countries have made the more timid among the Mexican population feel that geographical unity and unity of economic interest carried with them the danger that political unity might be forced upon the weaker state. They are obsessed by the belief that the United States wants to annex Mexico. They are confident that only the favorable opportunity is lacking. It would astonish them to know how small a part of the people of the United States have any but the vaguest of ideas about the republic and its people and how few of even these would consider annexation a thing to be desired. Those Mexicans who believe that an advance southward will be made as soon as an excuse can be found cannot know the history of their own country. Occasions for action there have been in great number. 
The United States does not "want" Mexico. To proceed to its annexation would be to act against its political impulses. In fact, as has been repeatedly shown, the United States will endure great provocation rather than come to conflict with the Mexican government. That under no circumstances will forcible action ever be taken nor any Mexican territory annexed is unfortunately a corollary, which some in Mexico have recently come to believe logically follows. Their opinion has unfortunately been given no little support by declarations made by prominent persons in the United States itself. The sooner reliance on any such statements is abandoned the better for the peaceful relations of the two countries. Neither Mexico nor any other state can count on the freedom from responsibility that such a policy would involve. The economic advantage that would result to the United States from annexation as contrasted to that which may follow independence and friendship is doubtful. Mexican trade, both import and export, is already almost inevitably American and investments will be increasingly so.

The United States does want order in Mexico, and for a number of reasons. Order would increase its profitable trade exchange, it would make secure the lives and properties of the many Americans whose interests are bound up with those of the republic and finally it would simplify maintenance of the fundamental principle of American foreign policy-that American states be not interfered with in their development by non-American political influences. Fair treatment for American and other foreign interests in Mex- 
ico and friendly adjustment of the questions that must affect the two governments because of their relative position, this is all that the United States wishes from its southern neighbor.

Mexican relations are not the most important factor in American foreign policy. At times they may rise to that prominence, but they can not be so permanently. They are important in themselves always and they are important because they do touch the larger international policy above referred to. In fact, the United States has often held the balance in Mexican foreign affairs, as must be familiar to all acquainted with Mexican history. Far from being a power wishing to overthrow Mexican independence, the United States has been its bulwark. It is certainly open to doubt whether there would exist to-day an independent Mexico if it had not been for the influence of the United States. The policy of America for Americans has meant something because the United States has stood ready to defend the principle.

Frankly speaking, this policy has not been a purely idealistic one. The United States has been moved by altruistic motives, but its own political and economic interests also have influenced its actions. Mexico can count on the continuance of this service in the future whether it recognizes and welcomes the protection or not. Similarly, the desire that Mexico shall remain independent and shall become a strong state able to protect itself, or at least contribute powerfully to its own protection is not only an altruistic desire on the part of the United States. 


\section{MEXICAN-AMERICAN RELATIONS 301}

There are many ways, of course, in which no other country can assist in this development. If Mexico is to find the way out of her travail to a worth-while independence, she must do so primarily by her own efforts. There are some ways in which she can be assisted. The granting of such assistance should be a part of the policy of the United States, not only because of its obligations to its neighbor, but also because of its obligation to itself.

Most of the means by which Mexican-American relations can be improved are, contrary to popular opinion, those in which the two governments are involved not at all or in a secondary manner. Greatly to be desired and fundamental, is the establishment of a better appreciation by the people of each republic of the people of the other and of their problems. To this end the government can contribute but little. Americans have known foreign lands so superficially that they have little patience with a foreign point of view. Their increasing touch with world affairs will help to banish their provincialism and make them see things through other men's eyes as they have not in the past. They will learn by contact to assimilate the good in other civilizations and develop a spirit of tolerance not now a striking characteristic. As this change occurs Americans will reach a new estimate of Mexicans.

The vision of Mexicans has not been wider. They also have felt the influence of the foreigner, but they have not come to appreciate him. One of the indirect beneficent results of the revolution will be the broadening of the national point of view, brought about by, 


\section{MEXICO AND ITS RECONSTRUCTION}

the return of the many thousands who, during the revolution, have been forced out of their own country into foreign lands, especially the United States. The new perspective, which these people will take back to their home communities, will not fail to have its influence upon the thought of others. They will have lost their short-range vision and will help their countrymen to a new appreciation of the position of Mexico in the world. From such changes of viewpoint the United States will profit.

The American people must hear a call to help Mexico through philanthropic activities. These depend upon the Government of the United States only for such friendly moral support as it may be able to extend. Bad sanitary conditions, poor educational facilities, and other conditions socially disadvantageous - the need for the elimination of these in Mexico should awaken a lively interest on the part of the people of the United States. It has not done so heretofore. In spite of the excellent efforts made, chiefly with church support, all that has been done is only a beginning. The well equipped and efficient philanthropic institutions, which under American management and support are doing such splendid work in the Far East and the Near East, have no counterpart in the nearer south. American philanthropy has not always heeded the injunction "Do the duty that lies nearest thee." It has not given its attention, as it should, to Mexico.

In spite of the evident present unwillingness of Mexico to admit it, there is little doubt that the United States must give financial assistance to the government. 
This is needed not only to meet the obligations of debts already incurred but to provide money to defray the expenses of the educational and social reforms that the government may very properly undertake for the bene= fit of the common people. How far this financing can be accomplished through loans made on purely private initiative can not be stated. Even if it could be wholly done thus, it is doubtful whether that standard should be accepted. The United States may very properly do what it can to assure that Mexico be given assistance under conditions that will be easy for her to carry. It may also seek to assure that its own citizens shall not enter speculative governmental contracts, the attempted enforcement of which would be likely to lead to international complications. The alternative which will be offered in Mexican loans will be high rates with poor guarantees for payment or low rates and good guarantees. The recent state of public opinion in Mexico indicates that her governments would prefer the former standard.

It is open to question whether considerations of good friendship permit the only country whose citizens are in a position to refinance Mexico to enter contracts such as Mexico would be glad to accept. Whether the special guarantee, which might be given, should be an hypothecation of certain sources of public income, or the establishment of a special customs service, or some other means that would protect the right of the lender, must be determined by circumstances not yet developed. It seems Mexico will very probably show unwillingness to give any special guarantee in return for financial aid. 


\section{MEXICO AND ITS RECONSTRUCTION}

It may be the part of friendship to wait until such unwillingness disappears, rather than to help her borrow money on conditions which, if fulfilled, may prove a drag upon her economic recovery and, if not fulfilled, a threat to international peace.

But the financing of the obligations of the government is not the only financial assistance Mexico will need. The industries already developed, especially her public services, will need large amounts of capital for their rehabilitation and their further expansion. Natural resources, until now almost untouched, can be brought to contribute to solving the problems of the republic only. by assistance from beyond the national boundaries.

These funds can be obtained on advantageous terms only if the foreigner is assured by Mexico and by his home government that the coöperation sought is not one back of which lies a narrow, anti-foreign, illiberal policy. If there is shown a genuine desire on the part of the Mexican government and Mexican people to have the help of foreigners in the development of the republic and if other states make clear to their investing citizens that conditions will not be allowed to arise in which they will find themselves harassed by legislation that will practically confiscate rights worthy of protection, this help, like that to the government itself, will be forthcoming on favorable terms. Mexico will again have the possibility of becoming a strong American state. If, on the other hand, the "nationalization movement" continues to show the characteristics that have marked it heretofore, there is no doubt that the reconstruction of Mexico will be at least greatly retarded. 


\section{MEXICAN-AMERICAN RELATIONS 305}

It is at this point, when the financial arrangements to be adopted and the rights of foreigners come under discussion, that the attitude of the Mexican government toward national reconstruction becomes most important. However great the mistakes of the Diaz régime may have been, there can be little doubt that the effort to improve the condition of the country by bringing about its economic development was wise. The assistance of the foreigner contributed powerfully to the creation of a new Mexico and the assistance of the foreigner may be made equally effective in raising Mexico from the low estate to which she has been brought by the revolution.

Those who now have in charge the destinies of the republic have the high responsibility of bringing that adjustment of material and non-material interests in which they believe their predecessors failed. They must find some means by which they can secure the financial assistance of the foreigner, without falling into the errors for which they criticize those formerly in power.

The economic foundations, upon which may rest the reforms Mexico may adopt, involve no other foreign country as they do the United States. Trade and investments make the interests of the two countries inseparable. These influences will accentuate their economic interdependence and should draw them into closer and more friendly political relations.

For the present there seems to be little prospect for such an entente cordial. The revolution in Mexico and the efforts of certain classes of foreigners during the World War have reawakened the spirit of distrust, 
which has so long made difficult a political understanding in spite of unity of economic interests. The intense nationalism of the local leaders has misled them. They have been drawn into an anti-foreign campaign, which can not be for the best interests of their country. They have set up the theory that the republic shall keep for itself entire freedom of action in matters political and economic. They seek to put the foreign resident and his property outside the protection of his home government. Those, whether Mexicans or not, who helped to foster this anti-foreign policy were no friends of Mexico.

Financially, whether we consider government obligations or private development enterprises, Mexico cannot be independent in the way some of her recent leaders have desired. The country she has called upon the most heavily for capital in the past has been the United States. The revolution has increased the necessity of that dependence. Mexico must borrow to repair the destruction of the revolution; she must seek an intensive development of her national resources in order to secure means for paying off her increased obligations and for improving the social and industrial life of her people. The World War has made it impossible for her to secure capital on the other side of the Atlantic under any conditions. However much she may desire to spread her borrowings, public and private, among a number of nations, she will find that stanaard impossible.

Little need be said to show that politically as well as economically Mexico should seek the friendship of the United States. If the principle that non-American 
states shall not be allowed to extend their control to the American republics be overthrown or abandoned, Mexico would not improbably be one of the first of the new world countries to suffer. The United States is the chief defender of the policy from which Mexico has already, in one instance, profited in a striking manner and by which her independence has now for a century been rendered more secure. Finally, a policy of enmity toward the United States would of itself endanger Mexican independence.

In considering the importance of Mexican-American relations from the point of view of the United States the economic motives are less important in themselves than the consequences that might follow the lack of good understanding. The Mexican import and export trade is of great and growing importance to the United States, as has already been shown. Mexico is a schooling ground for American importers and exporters. The experience acquired in the foreign market near at hand is valuable in the approach to others more distant. Mexico is the most important of the Latin countries as a place for the investment of American capital and it may continue to be so. Nevertheless the interruption of the economic connections between the two countries would bring no such consequences to the United States as it would to Mexico.

Friendship with Mexico is more important to the United States politically than economically. An enemy or an unfriendly power on the southern boundary would be a constant threat to the national safety. So also a country that cannot keep order within its own bound- 


\section{MEXICO AND ITS RECONSTRUCTION}

aries and give protection to the lives and property of foreigners is a menace to the United States only slightly less dangerous, because conditions may arise in such a country which, through the steps taken by other powers to defend the interests of their nationals, may draw the United States into international conflicts.

The United States, therefore, is in a position that demands that it shall do all that is within its power to help Mexico establish and maintain the public order upon which her economic salvation depends. Order is essential for the rehabilitation of Mexico and for the protection of the broader foreign policy of the United States; it is the starting point for all the other developments in Mexico that will help to strengthen the position of both countries and assure their good understanding.

The steps it may be necessary to take to assure order, and to impress upon the local government its duty to maintain it, may offend the susceptibilities of those in control in Mexico. In the past America has been frightened too often by such possibilities. There has developed a pallid Pan-Americanism, which has led the United States too often to refuse to do anything for fear of offending a Latin American country, even though by inaction its own just interests were caused to suffer. If that is the price that must be paid for Latin American friendship, it is not worth the price. In fact, no such condition exists. The Latin is moved by the same motives that prompt other peoples. A nation whose foreign policy is characterized by a firm insistence on respect for its citizens' rights never sacrifices the respect of other nations-even the respect of those against 
whom the action is taken. A national policy that insists upon the prompt and generous fulfillment of international duty in the protection of foreigners and in payment for damages done them is one that will do more to make America respected among the other nations of the New World than will one whose chief feature is the exchange of courtesies in which hard facts are glossed. Its influence will extend beyond our narrower national interests, because it will make those upon whom demands are made conscious of the responsibilities that accompany their international "equality" and spur them on to make it less a fiction.

There is no one element which, in the relations of the two more important republics of North America, is sufficient, if emphasized, to bring the good understanding that should exist between them. Nor can the good understanding be brought through official action only. The people of both countries must forget certain of their prejudices. The stronger nation must feel the call to help the weaker through both private and public initiative. It must help raise Mexico to a condition, social and economic, in which it can help itself. This, Mexico can not do alone. The weaker nation, on its side, must recognize the responsibilities, as well as the privileges, of independence. Toward those who have helped and those who will be called upon in the future to help in the development of the country, the government must show its good will by assuring them effective protection and by respecting the engagements they have entered.

Given a policy with these characteristics, there is no reason to believe that the relations between Mexico and 
the United States may not become increasingly intimate and friendly. Economic and political coöperation will then be possible in a positive way. It has been possible heretofore only in spite of lack of understanding on the part of both peoples and in spite of failure to realize their unity of interests. Coöperation and interdependence must succeed the distrust and "independence," so prominent, often, in the past. If Mexico is strong and "independent," in the broader sense of that word, she will be a friend of the United States, an ally in the defense of the principles in foreign policy for which the United States stands, and a bulwark against possible attack from the south. These she will be from principle and because her own best interests demand it. For the best interests of the United States no other standard of action is necessary. A friendly, strong, and independent Mexico will bring greater economic advantages than the annexation that certain classes of Mexicans fear and some citizens of the United States desire. It would contribute more to American political security. A friendly neighbor is a better bulwark than a disaffected province.

The arguments for a cordial understanding between Mexico and the United States are so compelling that it is hard to believe that they will be disregarded by those who guide the fortunes of the two republics. Without a strong and safe United States, Mexico can not be strong nor can its independence be assured. If Mexico is a weak and hostile nation, the United States is not safe, and an essential of the foreign policy of all American states is rendered less secure. 


\section{A SELECT LIST OF MATERIALS RELATING TO MEXICO}

Books

Anasagastr, Victorio de, México reconquista sus libertades, Madrid, 1918. A eulogy of Carranza and the revolution.

Andrade, Luis, Mexico en Espana, Madrid, 1919. A series of eulogies of certain revolutionary leaders.

ARnaud, M. P., L'emigracion et le commerce français au Mexique Paris, 1902.

BANCRoft, H. H., History of Mexico, New York, 1914.

Bexl, Edward I., The Political Shame of Mexico, New York, 1914. Brinsmade, R. B., El latifundismo Mexicano, Mexico, 1916. An uncritical discussion of the Mexican land problem.

Bulnes, Francisco, The Whole Truth About Mexico, New York, 1916. A somewhat pessimistic view of Mexican affairs by one of the ablest of Mexican scholars.

Butman, Arthur B., Report on Trade Conditions in Mexico. Transmitted to Congress in compliance with the Act of May 22, 1908, authorizing investigations of trade conditions abroad, Washington, 1908.

Butterfiedn, Carlos, United States and Mexico, Commerce, Trade and Postal Facilities Between the Trwo Countries, Washington, 1861.

Calderon de la Barca, Madame, Life in Mexico, 3rd ed., New York, 1910. Though originally appearing a generation ago this is still one of the most charming discussions of Mexican life.

Calero, Manuel, The Mexican Policy of President Woodrow Wilson as it appears to a Mexican, New York, 1916. A trenchant criticism of the policy of the American Government. and others, Ensayo sobre la reconstruccion de Mexico, New York, 1920. An excellent analysis of Mexican conditions. Carson, W. E., Mexico, the Wonderland of the South, New York, 1914. 
Castro, Lorenzo, The Republic of Mexico in 1882, New York, 1882.

Creelman, James, Diaz, Master of Mexico, New York, 1912. Cubas, Antonio García, Mexico, Its Trade, Industries, and Resources, Mexico, 1893. A good review of conditions in the middle Diaz régime.

-and Henderson, Geo. F., The Republic of Mexico in 1876.

Enock, C. R., Mexico, London, 1909.

Fornaro, C. de, and others, Carranza and Mexico, New York, 1915. An ultra-radical anti-American discussion.

Fornaro, C. de, Diaz, Czar of Mexico, New York, 1909.

Flandrau, Charles Macomb, Viva Mexico, New York, 1908.

Gunther, Erich, Handbuch von Mexico, Leipzig, 1912. A careful

study of Mexican conditions at the end of the Diaz régime.

HAgar, George J., Plain Facts About Mexico, New York, 1916.

Нuмвогdт, Alexander de, Political Essay on the Kingdom of Nere

Spain, 4 vols., London, 1811. The most comprehensive review

of Mexican conditions at the close of the colonial régime.

Hutchinson, Lincoln, The Panama Canal and International Trade, New York, 1915.

Lummis, C. F., The Aroakening of a Nation; Mexico of To-day, New York, 1898.

MacHugh, R. J., Modern Mexico, London, 1914.

McCaleb, W. F., The Public Finances of Mexico, New York, 1920. The most comprehensive review of this subject in English.

-Present and Past Banling in Mexico, New York, 1920. A well written historical analysis of Mexican banking with a discussion of the treatment of the banks by the revolutionary leaders.

Manero, Antonio, El antiguo regimen y la revolucion, Mexico, 1911. Manero, Vicente E., Documentos interesantes sobre colonizacion, Mexico, 1878. A collection of various official memorias on this subject.

- Noticias históricas sobre el comercio exterior de Mexico, desde la conquista hasta el año de 1878, Mexico, 1879.

Maqueo Castellanos, E., Algunos problemas nacionales, Mexico, 1909.

Martin, P. F., Mexico of the Trentieth Century, New York. -Mexico's Treasure House, New York, 1906. 
Mexican Company, Extracts from the report of Justus Ludwig von Uslar, relative to the "Negociacion" of Yavesia in the state of Oaxaca, January 6, 1828, n. p.

Mexican Yearbook, 1908-13.

Moses, Bernard, Railtway Révolution in Mexico, Berkeley, California, 1905. An excellent brief monograph.

Nimmo, Joseph, Jr., Commerce Betroeen the United States and Mexico. A report in reply to a resolution of the House of Representatives of January 31, 1884, Washington, 1884.

NoLx, Arthur H., A Short History of Mexico, Chicago, 1910.

Obregón, T. Esquivel, Infuencia de España y los Estados Unidos sobre México, Madrid, 1918. A discussion of the inapplicability of American political standards in Mexico.

Orozco, M., Observaciones sobre la influencia del comercio extranjero en la industria nacional y la conveniencia de restrinjirlo en la republica, Mexico, 1869.

O'Shaughnessy, Edith, A Diplomat's Wife in Mexico, New York, 1916.

Perigny, Maurice de, Les Etats-Unis du Mexique, Paris, 1911. A good review of the accomplishments of the Diaz régime.

Poinsetr, Joel Roberts, Notes on Mexico, Accompanied by an Historical Sketch of the Revolution, Philadelphia, 1824.

Ромво, Luis, Mexico: 1876-1892, Mexico, n. d.

Ros, F. Gonzalez, The Mexican People and Their Detractors, New York, 1916.

Romero, Matias, Mexico and the United States, New York, 1898. One of the best reviews of Mexican conditions by a Mexican author.

SAPPER, Dr. Karl, Wirtschaftsgeographie von Mexico, n. p., 1908. A very well written work.

Sierra, Justus, Editor, Mexico, Its Social Evolution, Mexico, 19004. A large and well printed collection of essays by various authors concerning the conditions of Mexico at the opening of the twentieth century.

Singer, J., Die Mexicanischen Finanzen und Wesens. Panamerikanische Politik, Berlin, 1914.

Smirh, R. W., Benighted Mexico, New York, 1916.

Stephan, Charles H., Le Mexique economique, Paris, 1903.

Starr, Frederick, Mexico and the United States, Chicago, 1914. 
Thompson, Wallace, The People of Mexico, New York, 1921. An excellent sociological study of the Mexican people.

Trowbridge, E. D., Mexico To-day and To-morrow, New York, 1919. Emphasizes the developments during the revolution, in which little is discovered that deserves criticism.

Turner, John Kenneth, Barbarous Mexico, Chicago, 1910.

Usher, Roland G., Pan-Americanism, New York, 1915.

Vera-Estañol, J., Carranza and His Bolshevik Régime, Los Angeles, 1920.

Whitney, Caspar, What's the Matter with Mexico, New York, 1916.

Winton, G. B., Mexico To-day, New York, 1913.

\section{Perrodicals, Pamphlets, and Documents}

Accounts and Papers (British) Commercial Reports, Session January 6-August 27, 1881, vol. 89, Report by Mr. Drummond respecting railways and trade in Mexico.

"Affairs in Mexico," Senate Document No. 25, 62d Congress, 1st Session.

Berichte über Handel und Industrie, Band 11, Berlin, 1907; Band 12, Berlin, 1908; Band 13, Berlin, 1910.

Blythe, S. G., "Interview with President Wilson," in Congressional

Record, vol. 51, part 9, p. 9096, May 23, 1914.

Boletines de la direccion general de estadistica, Mexico.

Boletín de la secretaria de fomento, Numero especial de propaganda, Julio, 1906, Mexico, 1906.

British Consular Reports passim, especially numbers 3726, 3733, 3958, 4102, 4189, 4287, 4498, 4846, 4976, 5175.

Bulletin of the Mexican News Bureau (semi-official), Washington, 1917.

Brady, Austin C., "Mexico's Fighting Equipment," Review of Revieres, vol. 34, p. 575, November, 1906.

Busto, Emiliano, editor, Anexo num. 3 a la memoria de hacienda del año economico de 1877 a 1878 , Estadística de la ropública mexicana, etc., Mexico, 1880.

Camerer, C. B., "Medico-Military Report on Parts of the West Coast of Central America and Mexico," United States Naval Medical Bulletin, vol. 7, p. 311, June, 1913. 
Carden, Lionel E. G., "Reports From Her Majesty's Diplomatic and Consular Officers Abroad on Subjects of Commercial and General Interest," Commercial No. 36, Part VII. Report by Mr. Lionel E. G. Carden on the trade and commerce of Mexico.

Carranza, Venustiano, "Report to Constitutional Congress at Querétaro," December 1, 1916, New York, pamphlet published by Latin American News Association.

Clark, W. A. G., "Cotton Goods in Latin America," Department of Commerce and Labor, Bureau of Manufactures, Special Agents Series, No. 31, part 1, Washington, 1909.

Commercial America-in 1907, Washington, 1909.

"Claims of American Citizens Against Mexico," Senate Document

No. 1, 66th Congress, 1st Session.

"Claims Against Mexico," Senate Document No. 67, 66th Congress, 1st Session, August 1, 1919.

"Commercial Information Concerning the American Republics and Colonies," Bulletin No. 41, Washington, 1892.

Commercial Relations, vol. 2, Washington, 1908.

Commerce Reports, Washington, passim.

Creet, George, "George Creel's Interview with Admiral Mayo," Congressional Record, vol. 54, part 6, p. 745.

Creelman, James, "A Discussion of Outrages in Mexico," reprinted in Congressional Record, vol. 51, part 4, p. 3928, February 25, 1914.

Dabney, Charles William, "A Star of Hope for Mexico," pamphlet reprinted from the Outlook, New York, 1917.

Exposición de la secretaria de hacienda de los Estados Unidos Mexicanos de 15 de enero 1879 sobre la condición actual de Mexico y el aumento del comercio con los Estados Unidos, rectificando el informe dirigido por el Honorable John W. Foster, enviado extraordinario y ministro plenipotenciario de los Estados Unidos en Mexico, el 9 de octubre, 1878 al Sr. Carlile Mason, presidente de la asociación de manufactureros de la ciudad de Chicago el estado de Illinois de los Estados Unidos de America, Mexico, 1879.

Fall, A. B., Speech in Congressional Record, vol. 51, part 5, p. 4512, March 9, 1914. An outline of outrages on American citizens during the revolution. 
F ALL, A B., in Congressional Record, vol. 52, part 4, p. 4279, February 22, 1915.

Speech in Congressional Record, vol. 53, part 9, p. 9165, June 2, 1916.

Flood, Henry D., A discussion of events in the Huerta régime in Congressional Record, vol. 53, part 15, p. 2170, Appendix, 1916.

GiL, Alberto Robles, Memoria de la secretaria de fomento presentada al congreso de la unión por ing., Mexico, 1913. A discussion of colonization problems.

House Document No. 13 (United States Congress), 45th Congress, 1 st Session.

House Document No. 145, part 5, 58th Congress, 3rd Session, International Bureau of the American Republics, Mexico. Contains a detailed description of the internal trade of each state in Mexico.

Huerta, Victoriano, "The Future of Mexico," Independent, vol. 82, p. 202, May 3, 1915.

Hulings, W. J., Speech in Congressional Record, vol. 51, part 5, p. 5141, March 19, 1914.

Hyde, George Edward, “A Plain Tale from Mexico," Nere Republic, vol. 2, p. 38, February 13, 1915.

Informes y documentos relativos a comercio interior $y$ exterior, agricultura é industrias, Mexico, 1885-7. A series containing the most important government reports on Mexican labor conditions.

"Investigation of Mexican Affairs." Hearing before a sub-committee of the Committee on Foreign Relations, United States Senate, 66th Congress, 1st Session, pursuant to S. Res. 105, Washington, 1919.

Jenner, G., "Report on Investments for British Capital in Mexico," Great Britain. Diplomatic and Consular Reports, Commercial No. 3, London, 1886.

Jerome, L. J., British Diplomatic and Consular Reports, Mexico, 1906, p. 3726.

Journal of the American Chamber of Commerce of Mexico, vols. 1 and 2, 1918-19.

Kelloga, Frederic R., "The Mexican Oil Problem," Nation, October $5,1918$. 
Lance, R. O., "Red Book-Mexico To-day and Our Position and Responsibility as a Nation Regarding Conditions in that Country," San Antonio, Texas, 1915.

LAWRENCE, David, "Mexico Rebuilding," Independent, July 28, 1917.

"The Inevitable Trend in Mexico," Century, vol. 90, n. s. 68, p. 737, September, 1915.

Lово, Gustavo, "More Light on Mexico," Unpopular Review, vol. 4, p. 140, July, 1915.

Mason, Gregory, "Mexico from the Inside Looking Out," Outlook, May 10, 1916.

Mason, Alfred Bishop, "The Cause of Revolution in Mexico," Unpopular Review, vol. 3, April, 1915.

Memoria de hacienda y crédito público, correspondiente al año economico de 1 de julio de -, a 30 de junio de -, Mexico. These reports, covering the years July 1 to June 30, are among the best material of a statistical nature published by the government during the Diaz régime. They are published at irregular dates after 1878 .

"Mexico, a Financial Handbook," The Mechanics and Metals National Bank of the City of New York, New York, 1917.

Monthly Trade and Consular Reports, Washington, passim.

Moses, Bernard, "Government in Spanish America," American

Political Science Review, vol. 8, p. 208, May, 1914.

NAson, Frank Lewis, "Political Mexico To-day," Yale Reviere, n. s. 1., p. 594, July, 1912.

Owen, Robert L., Speech in Congressional Record, vol. 51, part 9, p. 8517, May, 1914.

Papers Relating to the Foreign Relations of the United States, Washington. This series gives a fuller account of diplomatic relations between the two republics in the earlier than in the later years.

Pepper, Charles M., "Report on Trade Conditions in Mexico," Department of Commerce and Labor, Bureau of Manufactures. Special Agents Series, No. 4, Washington, 1906.

Protection of Landed Estates of American Citizens in Mexico, Senate Document No. 71, 66th Congress, 1st Session, August 11, 1919. 
"Purpose and Ideals of the Mexican Revolution," The American Academy of Political and Social Science, Philadelphia, 1917. Railway Age. Contains good current reports on transportation. Rapports commerciaux des agents diplomatiques et consulaires de France: Année 1902, No. 93, "Mexique," Paris; Année, 1903, No. 298, "Mexique," Paris; Année 1905, No. 4432, "Mexique," Paris.

REID, Frederick, "Must We Clean Up Mexico?" Sunset, vol. 36, p. 27, February, 1916.

Reviere of Revierws, vol. 50, p. 630, November, 1914.

Rolland, M. C., "A Trial of Socialism in Mexico," Forum, vol. 56, p. 79, July, 1916.

Romero, Matias, "Wages in Mexico," Commercial Information Concerning the American Republics and Colonies, 1891, Bulletin No. 41, Washington, April, 1892.

R'oosevelt, Theodore, "Our Responsibility in Mexico," New York Times, December 6, 1914.

Rowe, L. S., "Administrative Centralization in Mexico," Yale Review, vol. 12, p. 231, November, 1903.

"Sisal," bulletin published by the Comisión Reguladora del Mercado de Henequen, New York.

Steffens, Lincoln, "Making Friends with Mexico," Collier's, November $25,1916$.

Trichler y Cordova, Martin, "Constitutional Persecution of the Church," Outlook, vol. 114, p. 558, November 8, 1916.

Usher, Roland G., "Carranza's New Industrial Policy," North American Reviere, vol. 205, p. 398, 1917.

Wilfley, L. R., "The Land Problem in Mexico," North American Review, vol. 203, p. 867, 1916.

Wolfe, A. J., "Foreign Credits," Department of Commerce and Labor, Bureau of Manufactures, Special Agents Series, No. 62, Washington, 1913.

Young, Arthur N., "Finances of the Federal District of Mexico," Mexico, 1918.

"France's Stake in Mexico," Nation, vol. 98, p. 290, March $19,1914$.

"German Efforts in Mexico," World's Work, vol. 35, p. 208, 1917.

"Mexico, Its Political Situation, Its Resources and Its Military. 
Strength," Scientific American, vol. 114, p. 450, April 29, 1916.

"The Mexican Oil Question," with documents and translations, n. p. n. d. A compilation of extracts from Mexican decrees, constitutions, laws, and diplomatic notes protesting against the action of Mexico as to oil properties.

“Must We Invade Mexico?” Independent, vol. 83, p. 392, September 20, 1915.

Nation, vol. 34, p. 399, May 11, 1882; vol. 35 , p. 198, September 7, 1882; vol. 38, p. 69, January 24, 1884; vol. 78, p. 448, June 9, 1904; vol. 79, p. 194, September 8, 1904. Resolutions of American refugees adopted at San Antonio, July 18, 1916, published in extension of remarks by Jefferson McLemore in Congressional Record, vol. 53, part 15, p. 1564, Appendix, 1916.

"What War With Mexico Means," World's Work, vol. 32, pp. 425-30, August, 1916. 



\section{INDEX}

Acapulco, and foreign commerce, 191

Aguascalientes, population of, 12

Agricultural machinery, imported from United States, 194, 202

Agriculture in Mexico, development of, 184, 185, 207, 237

during revolution, 184

since year 1918, 185

Alcabala, 96, 97, 99, 192

Americans in Mexico, 25, 26, 233-236, 239-270

American-Mexican relations, 263, 271-310

See also United States.

American policy toward Mexico, 4-9

See also United States.

Antuñano, Esteban, and cotton weaving, 177

Asia, Mexican trade relations with, 190

Bandelier, Adolph F., estimation of wages of farm laborer in year 1884, by, 135

Banking system of Mexico, 8393

present status of, 92

Bilimbiques, 86

Brandy, production of, in Mexico, 179
Breadstuffs exported f rom United States to Mexico, 194

Breweries, in Mexico, 179

Cabrera, Luis, 75

Cabrera (Minister), 89

Calero, Manuel, 295

Camarilla stage of government in Mexico, 36

Campeche, population of, 16

Candy and chocolate factories in Mexico, 178

Canned provisions exported from United States to Mexico, 194

Carranza, 39, 51, 52, 74 "bilimbiques" issued by, 86 coinage system under, 85-87, 89,90

customs receipts under, 217 death of, 53 foreign capital and, 251-261 loans contracted by, 72, 75, 76 labor problem under, 142 Catholics in Mexico, 21

Cattle, hides and skins exported from Mexico, 210

Cattle industry in Mexico, 184

Chamizal controversy, 298

Chemical products, importation of, by Mexico, 202

Chiapas, population of, 11,16

Chicle exported from Mexico, 210

Chihuahua, population of, 26

Chinese in Mexico, 26 
Church as political factor in Mexico, 21

Coahuila, population of, 13, 26 Coal:

effect of lack of supply on industry in Mexico, 180 importation of, into Mexico, 202

Cochineal, exportation of, from Mexico, 191, 195

Cochineal industry during nineteenth century in Mexico, 176

Coffee:

crop of, in Mexico, 184, 208, 210

exportation of, from Mexico, 197

Cocoa exported from Mexico, 191

Coinage system, Mexican, 8393

during Diaz régime, 84

effect of World War on, 90

relation of, to taxing system, 84

Coke, Governor of Texas, and Mexican relations, 277

Colonization enterprises of Mexico, 220-238

"concessions" and, 240

Germans and, 245

Commerce, Mexican, foreign, before Diaz régime, 187198

exports of metals, 189 effect of, on economic development, 192 exports, 189-198 imports, 189-191, 193-198 smuggling, 193 Spanish trade regulations for Mexico, 187, 190 statistics regarding, 192 steamship communications, 198
Commerce, Mexican, foreign:

tariff system, 192-194

Vera Cruz as shipping center, 189

with Asia, 190

with Philippines, 190

during and after Diaz régime, 199-219

effect of World War on, 217 exports, 202-217

imports, 199-206, 217

tariff system, 199-202

Commerce, Mexican, internal, 175-186

See also Industry and Internal Commerce of Mexico.

Constitution of year 1857, 3032,253

Constitution of year 1917, 144, 253-256, 264, 265

Copper:

importation of, into Mexico, 68,202

exportation of, from Mexico, 189

Corral, 49

Cotton:

exportation of, 189

importation of, 201

manufacture of, 193

Cotton weaving in Mexico, 176,

177

and Esteban Antuñano, 177

Crops, production of, in Mexico, 216

Cubans in Mexico, 26

Diaz-Madero election, 49

Diaz régime, $32,33,35,36,38$, $43,44,46,47,48,49$, $50,53,60$.

and colonization concessions, 241,249

attitude of, toward United States, 279-296 
Diaz régime:

beginning of, 277

coinage system during, 84

colonization during, 231

commerce, foreign, before, 187-198

commerce, foreign, during and after, 199-219

Congress during, 39

courts during, 40

division of Mexico into zones during, 13

financial condition during, 5, $66,67,97,100,101$

financial standing at close of, 74

foreigners as factor in trade during, 183

labor conditions during, 116, 124-126, 129, 130, 131, 134, 138

large estate system during, 155

lawlessness during, 276 military problems during, 3335

position of jefes politicos during, 63

railroad project during, 163166 168-171, 174

effect of, on economic conditions, 169, 174

tariff rates during, 194, 200 taxing system during, 100

Education in Mexico, 22-24, 27

Elections, Mexican, 42-57

Electrical goods, importation of, into Mexico, 202

Electrical power development in Mexico, 179

English settlers in Mexico, 25

European powers:

attitude of, toward Haiti, preceding the World War, 8
European powers:

financial interests of, in Mexico, 8

External Consolidated Gold Loan, 69

Finance, Mexican, 66-103

at close of Diaz régime, 74

at outburst of World War, 72;

79

banking system, 83-93

present status of, 92

domestic obligations, 83

domestic readjustment in the early ' 90 's, 88

foreign claims, 66-82

foreign commerce, 98

foreign loans, 66-68

present condition of, 73-83, 93

public income and expenditure, 94-103

during Diaz régime, 101'

railroad building for furthering of, 98

See also Taxing System in Mexico

Fish, Secretary of State, and Mexican relations, 277

Fletcher, Henry, American Ambassador to Mexico, 270 Foreign population of Mexico, 25

lack of accurate census regarding, 25

Foster, Minister, 282

Flour exported from United

Foodstuffs:

States to Mexico, 194

importation of, into Mexico, 201

production of, in Mexico, 201 Foreigners in Mexico:

capital invested by, 239-252 total amount of, 247 
Foreigners in Mexico:

immigration of, 233-236

legal status of, 252-270

property of, 239-252, 256258

confiscation of, 260

Foreign investments in Mexico:

by Americans, 24:2-244, 247

by British, 244-247

by French, 245-247

by Germans, 245-248

France:

capital of, invested in Mexico, 245-247

Mexican trade relations with, 193, 194-195, 196, 200, 203

property of, in Mexico, 245 confiscation of, 260

French population in Mexico, 25,26

Garbanzos, exported from Mexico, 210

García, Jesus, 288

German population in Mexico, 25,26

\section{Germany:}

capital of, invested in Mexico, 245-248

colonization interprises and, 245

trade relations of, with Mexico, 194, 195, 200, 203

Glass and faience factories in Mexico, 176

Gold exported from Mexico, 189 Gonzalez, 50, 52

Government of Mexico, 28-85 camarilla stage, 36 conservative party in, 42-44. constitution of year 1857,30 32,253

constitution of year 1917, 144, 253-256, 264, 265
Government of Mexico:

during Diaz régime. See under Diaz régime.

elections, 42-57

executive, 28-41

judicial, 30,40

legislative, 29

Liberal party in, 43, 44

local, 58-65

town council (ayuntamiento), 62

military problems, 33-35

State governments, 58-65

taxing system. See Taxing System of Mexico.

Great Britain:

capital of, invested in Mexico, 244, 247

Mexican trade relations with, 193, 194, 195, 196, 200, 203, 211

property of, Mexican confiscation of, 260

Greek Orthodox in Mexico, 22 Groceries, trade in, in Mexico, 182, 194

Guatemalans in Mexico, 26

Guayule, exported from Mexico, 210

Guerero, population of, 16

Hacendados, 139

Haiti, attitude of European powers toward, preceding the World War, 8

Hardware trade in Mexico, 183, 194

Hats, exported from Mexico, 211

Henequen, exported by Mexico, 208

Hides exported from Mexico, 189,197

Holland, property of, Mexican confiscation of, 260 
Huerta, 50, 51, 53, 74, labor legislation and, 142 Hughes, Secretary of State, and Mexican relations, 264

Humboldt, Alexander von: estimation of Mexican population by, 12

estimation of wages of agricultural laborer in year 1804 by, 135

Indian tribes in Mexico, 16 Indigo exported from Mexico, 189

Indigo industry during nineteenth century in Mexico, 176

Industry and internal commerce of Mexico, 175-186

agriculture, 184, 185

brandy, 179

breweries, 179

candy and chocolate factories, 178

cattle industry, 184

cochineal, during nineteenth century, 176

coffee crop, 184

coining of silver, 175

cotton goods, 176, 177, 178

effect of development of oil regions on, 180

effect of lack of coal on, 180

effect of re-adoption of gold standard on, 186

effect of revolution on, 185

electrical power development, 179

foreigners as a factor in, 181183

glass and faience factories, 176

groceries, 182

hardware, 183
Industry and internal commerce: indigo, during nineteenth century, 176

inducements offered by the government in nineteenth century, 176

influence of foreign trade on, 180-182

iron and steel, 182

jewelry, 182

jute, 178

liquor trade, 182

machinery and machinery supplies, 183

Mexico City as center of, 184 mining, 185, 195

present status of, 183

printing establishments, 176

rum, 178

silks, 176, 182

silver, 175,185

stock-raising, 184

sugar, 178, 184

textile manufacturing, 175178

centers of, 176

tobacco manufacture, 179,185

woolen goods, 176, 178

Infalsificable notes, 86,89

Iron, exportation of, from Mexico, 202

Iron and steel, importation of, into Mexico, 194, 202

Iron and steel industries in Mexico, 182

Iron goods, importation of, into Mexico, 203

Israelites in Mexico, 22

Jalisco, population of, 14

Jefes politicos, 63 during Diaz régime, 63

Juarez, 43

second election of, 50

Jute manufacturing, 178 
Labor contract in Mexico, 112184

Labor problem in Mexico, 104160

aboriginal races and, 112

and the revolution, 144-147

baldios and, 120

by tarea system, 128

during Diaz régime, 116, 124126, 129, 130, 131, 134, 138

faena and, 122

foreigners and, 110 government statistics on, 116, 130

rate of wages, 135

hacendados and, 125, 134, 143

Indians and, 106-109, 111, $112,121,126-128$

labor union movement, 140142,146

legislation in connection with, $123,127,143$

mestizo class, 109, 111, 112 peonage system, 115, 117,

$121,129,130,133$

pulque trade and, 143

punteros and, 121

raya and, 122

socorro and, 122

tarea and, 122

task laborers, 122

term contracts, 117-120, 122

wage rates, 118-120, 122, 126,

$128,131,135-147$

effect of World War on,

140

for children, 137, 143

for females, 13\%, 143

for males, 137, 143

working hours, 118, 143

Laborer, Mexican, 104-160 contract of, 112-134.

demands of, 112-134

See also Labor Problem in Mexico.
Land problem in Mexico, 148160

Languages of Mexico, 18, 19

Maya, 19

Mexicanos, 19

Nahuatl, 19

Otomi, 19

Spanish, 19

Zapotecano, 19

La Novia, revolution of, 43

Lard, importation of, into Mexico, 201

Latin-American countries, attitude of United States toward, 6

Leather goods, importation of, into Mexico, 201

Lerdo, 43, 50

Leyes de Deslindes, 152

Lill, Thomas R., 74

Liquors, trade in, in Mexico, 182,194

Literacy of Mexicans, 22-24, 27 census statistics, 22-24

Machinery:

exported from Mexico, 194

imported by Mexico, 202

Machinery trade, control of, by Americans, in Mexico, 183

Madero régime:

financial condition during, 74

labor problem and, 142

Maximilian, régime of:

colonization during, 245

floating of loan in year 1864 by, 68

Maya, language of, 19

Mayas, 11

Meats, preserved, importation of, into Mexico, 201

Mestizo population in Mexico, 17,26 
Metal goods exported from MexMetals:

$$
\text { ico, 194, } 195
$$

exported from Mexico, 202, 205,210

importance of, as resource in Mexico, 189

Mexican-American relations, 49 , $72,263,271-310$

See also Mexico.

Mexican "Border," 271-296

Mexican finance, 66-103

See also Finance, Mexican.

Mexican laborer, 104-160

See also Labor, Mexican.

Mexicano, 19

Mexicans in United States, 273 Mexico:

attitude of United States toward, 4-9, 72, 279-310

colonization enterprises of, 220-238

commerce, foreign, before Diaz régime, 187-198; see also Commerce, Mexican during and after Diaz régime, 199-219; see also Commerce, Mexican.

with United States, importance of, 6

commerce, internal, and industry, 175-186; see also Industry and Internal Commerce of Mexico

ecoinomic development of, 5, 7, $10,11,40$

effect of agricultural experimental work on, 237 effect of agricultural exports on, 208-210

effect of American investments on, 24:2-244

effect of exportation on, 207-214

effect of importation on,
Mexico, economic development:

effect of labor problem on, 104-185

effect of manufacturing on, 175-186

effect of political problem on, 112,170

effect of railroads on, 169

effect of tariff on, 199

foreigners in, 239-270; see also Foreigners in Mexico.

government of, 28-85

industry and internal commerce of, 175-186; see also Industry and Internal Commerce of 'Mexico.

languages of, 18, 19

municipal government of, 5865

natural wealth of, 5 population of, 10-27

present status of civilization in, 5

racial development of, 14-16

among Indian tribes, 16

resident international interests within, 5,10

social status of, 11,17

transportation facilities in, 161-174

Mexico City, as center of commerce 184

Michoacan Jnpulation of, 14, 16

Mining in Mexico, 185, 195

Mineral products exported from Mexico, 205

Minerals, importation of, into Mexico, 202

Miztecs, 16

Mohammedans in Mexico, 22

Monterey and Mexican Gulf Railway, 69

Municipal government of Mexico, 58-65 
Nahuatl, 19

National Railways of Mexico, General Mortgage four per cent gold bonds, 71, 72

Native population of Mexico, 26 Neuvo Leon, population of, 26

Oaxaca, population of, 14, 16 Obregón, 52, 53, 75, 174, 263

Occupations of Mexicans, 24

lack of accurate census of, 24

Ochre exported from Mexico, 189

Oil:

exported from Mexico, 191, 206

status of, during and after Diaz régime, 206, 257, 261-264

Oil regions of Mexico, effect of development of, on indus-

Otomi, 19 try, 180

Ord, General, 280-282

Ord Order, 281

Palacio, Vincente Riva, 229

Petroleum, status of, in Mexico, $218,258-260,262$

Peonage system in Mexico, 115, $117,121,129,130,133$

Philippines, Mexican trade relations with, 190

Pious Funds dispute, 298

Polk, General, 283

Population of Mexico, 10-27
Americans, 25
Chinese, 26
Cubans, 26
English, 25
foreigners, 25
French, 25, 26
Germans, 25, 26
Guatemalans, 26

Population of Mexico: in Aguascalientes, 12 in Campeche, 16 in Chiapas, 13, 16 in Chihuahua, 26 in Coahuila, 13, 26 in Guerero, 16 in Jalisco, 14 in Michoacan, 14, 16 in Nuevo Leon, 26 in Oaxaca, 14, 16 in Puebla, 13 in Sonora, 13, 26 in Tarahumaras, 16 in Tarascas, 16 in Tepehuanas, 16 in year 1890,13 in year 1910, 13 in Yucatan, 13, 16 Indian tribes, 16 lack of accurate census of, 11 literacy of, 22-24, 27

Mayas, 11 mestizo, 17

Miztecs, 16 native, 26 occupations of, 24 religion of, 19-22

Spanish, 25, 26 white, 14, 16-18, 26 Yaquis, 11, 16 Zapotecs, 11, 16

Printing, in Mexico, 176

Protestants in Mexico, 22

Public income and expenditure, Mexican, 94-103

See also Taxing System of Mexico.

Puebla, population of, 12

Quicksilver, importation of, into Mexico, 202

Racial development of Mexico, 14, 16 
Railroads in Mexico, 162-174 demoralization of, 171-178, 174

establishment of, 162 advantages as a result of, 169 attitude of United States toward, 163

effect of, on economic condition, 169, 171-173

effect of, on international relations, 169

Mexican Central Railroad, 168,248

Mexican National Railroad, 168,243

public policy, before Diaz régime, $163-168$

during Diaz régime, 163$166,168-171,174$

reëstablishment of, 173

Railway equipment, importation of, into Mexico, 202

Religion, of Mexicans, 19-22

Reyes, Bernardo, 38

Romero, Matias, estimation of wages of day laborers in 1896 by, 136

Root, Elihu, 294

Rubber exported from Mexico, 210

Rum, manufacture of, in Mexico, 178

Santa Ana, 223, 228

Silk industry in Mexico, 176, 182

Silver, Mexican: coining of, 175

exports of, 189, 191, 218

supply of, 206,218

value of, 85,218

Sisal, production and exportation of, 209

Sonora, population of, 13,26
Spain, trade regulations of, for Mexico, 187, 190

Spaniards in Mexico, 25, 26

Spanish conquest of Mexico:

economic development under,

$104,187,220$

taxes during, 95

Spanish land policy, 149

Spanish language in Mexico, 19

Stockraising in Mexico, 184

Sugar in Mexico, 178, 184

Sulphur exported from Mexico, 189

Taft, William Howard, 295

Tarahumaras, 16

Tarascas, 16

Tariff system:

before Diaz régime, 192

during Diaz régime, 199, 202

Taxation system in Mexico, 59$62,94-100$

and concessions, 241

and foreign property, 259-264 bullion tax, 97

consumption taxes, 59

during Diaz régime, 100

during period following Spanish rule, 96-98

during period of Spanish rule, 94-97

federal, 100

for land, 102

license, 100

lottery tax, 96, 100

for commerce, $59,96,198$

internal (alcabala), 96, 97, 99

for industry, 59

for precious metals, 84

for professions (patente), 59

for property, 59

paper tax, 96

poll taxes, 60

predial, 100 
Taxation system:

professional tax, 100

pulque tax, 97

rate of levy, 59

relation of, to coinage system,

84.

stamp taxes, 96, 97, 100

tobacco tax, 97

Tehuantepec Railway Loan, 69, 75

Tepehuanas, 16

Textile manufacturing in Mexico:

in sixteenth century, 175-176

centers of, 176

cotton goods, 176, 177, 178

cotton factories, 178

silk weaving, 176

woolen goods, 176, 178

Textiles, importation of, into

Mexico, 199, 203

Tin, exportation of, 189

importation of, 202

Tobacco:

manufactured in Mexico, 179, 185

exportation of, 211

raw, exported from Mexico, 210

Town government of Mexico, 58-65

Transportation facilities in Mexico, 161-174

cost of, before building of railroads, 162

Indian carriers, 162

railroads, 162-174, 198

Tuxtepec, revolution of, 43

United States:

attitude of, recent, toward Mexico, 263, 271-310

toward Diaz régime, 279296

toward Latin American countries, 6
United States :

toward Mexican railway projects, 163, 169, 174 attitude of Mexicans toward, in railway project, 163169,174

in seventeenth century, 221 capital of, invested in Mexico, 24.2-244, 247

commercial relations of, with Mexico, 6, 193-195

foreign policy of, toward Mexico, 4-9, 72, 279-310 Mexican trade relations with, 193, 195, 196, 198, 202, 203-205, 210-213, 217

property of, Mexican confiscation of, 260-264

"Unoccupied" land, in Mexico, 149-152

Vanilla, exported, 210

Vegetable fibers, exported, 210

Vegetable substances, importation of, into Mexico, 201

Vera Cruz, 189-191.

Villa, 86

Wine, imports of, from France, to Mexico, 195

export of, from Mexico, 191

Wood exported from Mexico, $189,197,210$

Wool, exportation of, 189, 191 importation of, 200, 201

Woolen manufacturing in Mexico, 176, 178

Yaquis, 11, 16

Yucatan, population of, 13, 16

Zapata, 86

Zapotecs, 11, 16, 19 




\section{BOOKS ON FOREIGN MARKETS}

\section{FOREIGN TRADE MARKETS AND}

METHODS By Clayton S. Cooper $A$ clear and authoritative guide to the entire subject of overseas commerce. It discusses and analyzes in practical fashion world markets and the agencies and methods of foreign trade.

\section{TRADING WITH ASIA}

By Frank $R$. Eldridge, Jr, A business-like estimate of the potentialities of the Asiatic markets, which surveys economic and political conditions together with the products and resources of all parts of the Far East.

\section{STRAIGHT BUSINESS IN SOUTH}

AMERICA By James $H$. Collins

Tells exactly what the facts are concerning trade with South America and how business is best conducted there either on the spot or from the home desk.

\section{EXPORTING TO LATIN AMERICA}

By Ernst B. Filsinger

A timely volume for merchants and commercial houses on all matters relating to trade with the countries of South America.

\section{MEXICO AND ITS RECONSTRUCTION}

By. Chester Lloyd Jones

The most comprehensive and authoritative book on the Mexican situation. It will be read with profit by everyone desiring definite information on conditions in Mexico.

\section{COMMERCIAL POLICY}

By William Smith Culbertson A survey of the whole field of commercial policy in war time and after. Tariffs, preferences, discriminations, export trade, foreign investments and concessions, the "open door," etc.

\section{APPLETON AND COMPANY NEW YORK LONDON}




i: 
(1) (9. 2.

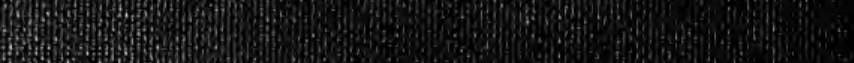

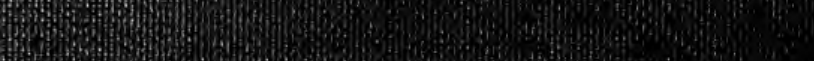
A 6. 20

a H. Ha 